Key Words:

Hybrid Sulfur

Nuclear Hydrogen

Thermochemical

PBMR

Retention:

Permanent

\title{
HYBRID SULFUR PROCESS REFERENCE DESIGN AND COST ANALYSIS
}

\author{
FINAL REPORT
}

Co-authors:

M.B. Gorensek, W.A. Summers (SRNL)

C.O. Bolthrunis (Shaw)

E.J. Lahoda (Westinghouse Electric Co.)

D.T. Allen (Technology Insights)

R. Greyvenstein (PBMR)

REPORT DATE: JUNE 12, 2009

Savannah River National Laboratory

Savannah River Nuclear Solutions

Aiken, SC 29808

Prepared for the U.S. Department of Energy Under

Contract Number DE-AC09-08SR22470 


\section{DISCLAIMER}

This work was prepared under an agreement with and funded by the U.S. Government. Neither the U. S. Government or its employees, nor any of its contractors, subcontractors or their employees, makes any express or implied:

1. warranty or assumes any legal liability for the accuracy, completeness, or for the use or results of such use of any information, product, or process disclosed; or

2. representation that such use or results of such use would not infringe privately owned rights; or

3. endorsement or recommendation of any specifically identified commercial product, process, or service.

Any views and opinions of authors expressed in this work do not necessarily state or reflect those of the United States Government, or its contractors, or subcontractors.

Printed in the United States of America

Prepared for

U.S. Department of Energy 
This page intentionally left blank.

- ii - 


\section{Table of Contents}

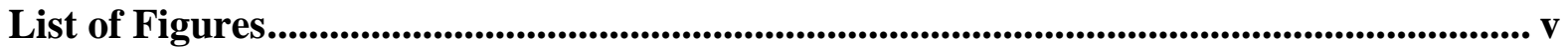

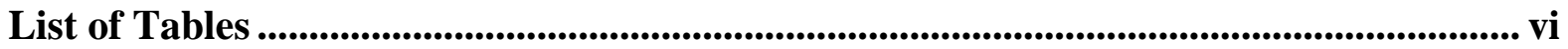

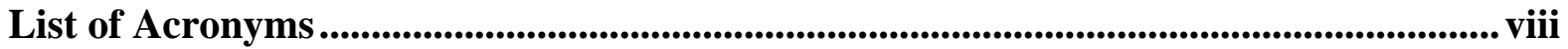

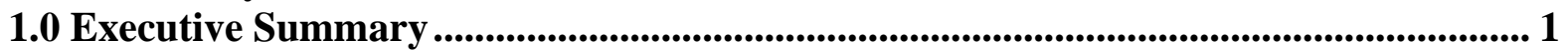

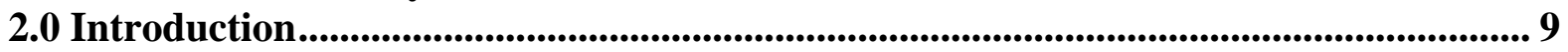

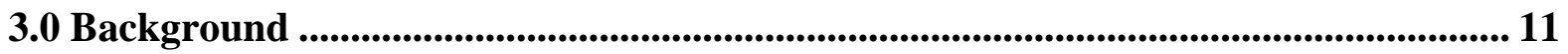

3.1 Nuclear Hydrogen Production .......................................................................... 11

3.2 Pebble Bed Modular Reactor ............................................................................... 12

3.2.1 PBMR Product Range ........................................................................................ 13

3.2.2 Value Proposition ........................................................................................... 13

3.2.3 Projects Update .......................................................................................... 13

3.2.4 PBMR Hydrogen Production .................................................................................. 14

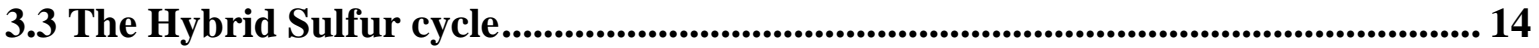

3.3.1 The $\mathrm{SO}_{2}$-Depolarized Electrolyzer............................................................... 16

3.3.2 The Acid Decomposition Reactor ................................................................................ 19

3.3.3 Energy Considerations.................................................................................... 21

3.3.4 Heat Requirement for the Bayonet Decomposition Reactor ............................. 23

4.0 Reactor - Hydrogen Plant Interface ........................................................................................ 28

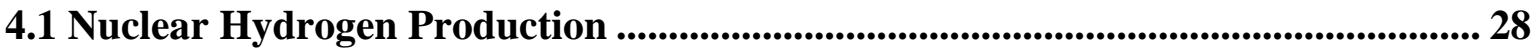

4.2 Design Envelope Constraints and Design Options ................................................. 30

4.3 Primary and Secondary Heat Transfer System Designs............................................ 34

4.4 Performance Summary of Design Cases ........................................................................... 38

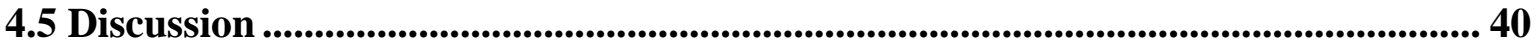

5.0 Hybrid Sulfur Process Flowsheet ........................................................................ 41

5.1 Integrating the Decomposition Reactor with a PEM SDE ................................... 41

5.2 The PEM SDE / Decomposition Reactor Hybrid Sulfur flowsheet ........................ 42

5.3 Flowsheet energy requirements...................................................................................... 53

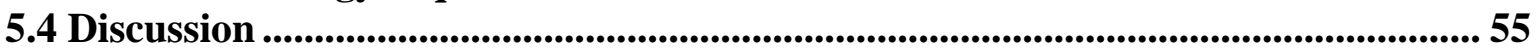

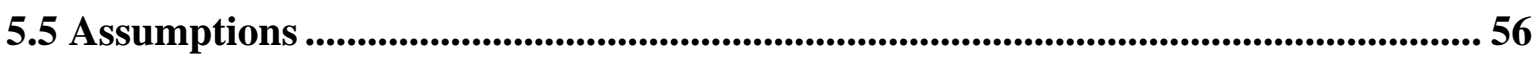

5.6 Flowsheet Summary and Conclusions ....................................................................... 58

5.7 Energy Integration Study …............................................................................................... 59

6.0 Plant Conceptual Design and Cost Estimate ........................................................................61 61

6.1 Reference Design Performance Summary ......................................................... 61

6.1.1 PBMR-NHSS Reference Design Summary ........................................................... 61

6.1.2 Hybrid Sulfur Process Performance Summary................................................... 61

6.1.3 Overall Reference Design Performance Summary ........................................ 63

6.2 Equipment Selection and Sizing and Materials of Construction ............................. 64

6.2.1 Equipment Selection and Sizing............................................................................ 64

6.2.2 Materials of Construction..................................................................................64 64

6.3 Commercial Electrolyzer Design and Cost .................................................................. 65

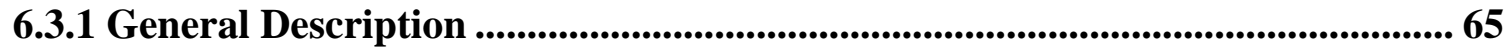

6.3.2 Design Requirements and Specifications ......................................................... 65

6.3.3 Module Conceptual Design...........................................................................6 66

6.3.4 Electrolyzer Plant Arrangement..........................................................................6 67 
6.3.5 Capital Cost Estimate .................................................................................................... 67

6.4 Plant Capital Cost Estimates............................................................................................ 70

6.4.1 Reference Capital Cost Estimate .................................................................................. 70

6.4.2 Alternative Capital Cost Estimates .......................................................................... 74

6.5 Plant Lifetime Costs ............................................................................................................. 77

6.5.1 Replacement Capital Costs................................................................................... 77

6.5.2 Operating and Maintenance Costs .............................................................................. 78

7.0 Cost of Hydrogen Estimate .................................................................................................. 86

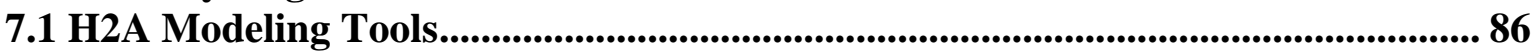

7.2 Hydrogen Price Baselines ................................................................................................ 87

7.2.1 Natural Gas Steam Reforming................................................................................... 87

7.2.2 Alkaline Water Electrolysis.......................................................................................... 90

7.3 Hybrid Sulfur Price Calculation Input................................................................................... 92

7.3.1 Economic/Financial Assumptions................................................................................. 92

7.3.2 Component Cost Data and Bases.................................................................................... 93

7.3.3 Hydrogen from the HyS Cycle ............................................................................. 93

7.4 Sensitivity Analysis ...........................................................................................................99

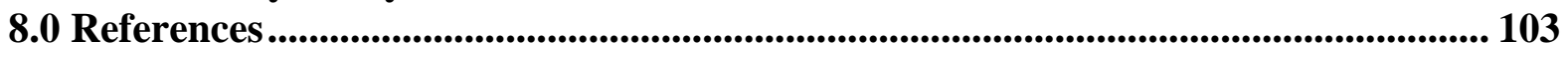

9.0 Appendix - Nuclear Hydrogen Production with the PBMR ........................................ 106

9.1 Nuclear Energy Source ........................................................................................................ 106

9.1.1 Substitute Capital for Natural Gas........................................................................... 107

9.1.2 Eliminate $\mathrm{CO}_{2}$ Emissions............................................................................................. 107

9.1.3 Petroleum and Global Warming................................................................................. 107

9.1.4 Clean Coal Conversion ................................................................................................. 107

9.1.5 Summary …......................................................................................................... 107

9.2 Pebble Bed Modular Reactor ..................................................................................... 108

9.2.1 How the PBMR Works .............................................................................. 108

9.2.2 How the PBMR Fuel Works................................................................................ 111

9.2.3 The PBMR'S Safety Features .................................................................................. 113

9.2.4 Why a core meltdown or Chernobyl-type accident is not possible................... 114

9.2.5 How the PBMR Project Came About....................................................................... 116

9.2.6 The Pebble Bed Evolution ........................................................................................... 118

9.2.7 Why PBMR for Process Heat................................................................................... 121

9.2.8 Product Range ................................................................................................................... 121

9.2.9 Process Applications and Markets..................................................................... 122

9.2.10 Value proposition ............................................................................................. 122

10.0 Appendix - Energy Integration Study .............................................................................. 124

11.0 Appendix - Hybrid Sulfur Plant Equipment List............................................................ 130

11.1 Electrolysis Section .......................................................................................................... 130

11.2 Sulfuric Acid Decomposition Section............................................................................. 132

11.3 Feed and Utility Supply Section ............................................................................. 136

11.4 Product Purification Section................................................................................................. 138

12.0 Appendix - HyS Plant Materials Selection Summary ..................................................... 142

13.0 Appendix - Economic Groundrules.................................................................................. 149 


\section{LIST OF FIGURES}

Figure 1-1 Hybrid Sulfur (HyS) Cycle Reaction Steps ………............................................ 3

Figure 1-2 Schematic View of Nuclear Heat Supply System................................................ 4

Figure 3-1 The Hybrid Sulfur (HyS) Cycle ................................................................ 15

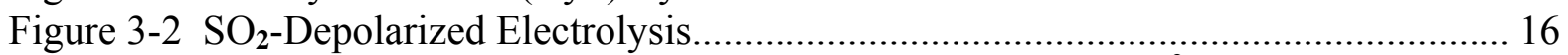

Figure 3-3 HyS Electrolyzer Test Facility showing close-up of $60-\mathrm{cm}^{2}$ test unit ................. 18

Figure 3-4 Multi-cell HyS Electrolyzer Stack ................................................................ 18

Figure 3-5 Schematic diagram of the SNL bayonet decomposition reactor .......................... 20

Figure 3-6 Decomposition Reactor heating and cooling curves $-80 \% \mathrm{H}_{2} \mathrm{SO}_{4}$ feed, 86-bar pressure, $870^{\circ} \mathrm{C}(1143 \mathrm{~K})$ peak process temperature, $675^{\circ} \mathrm{C}(948 \mathrm{~K})$ catalyst bed inlet

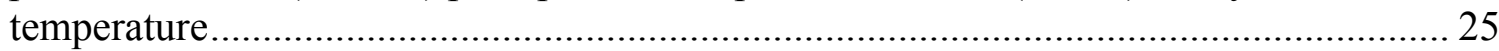

Figure 3-7 High-temperature heat requirement for $\mathrm{H}_{2} \mathrm{SO}_{4}$ decomposition as a function of feed concentration ( 30 to $85 \%$ ) at three different pressures, $870^{\circ} \mathrm{C}(1143 \mathrm{~K})$ peak process temperature, $675^{\circ} \mathrm{C}(948 \mathrm{~K})$ catalyst bed inlet temperature.......................................... 26

Figure 3-8 High-temperature heat requirement for $\mathrm{H}_{2} \mathrm{SO}_{4}$ decomposition as a function of feed concentration ( 70 to $85 \%$ ) at four different pressures, $870^{\circ} \mathrm{C}(1143 \mathrm{~K})$ peak process temperature, $675^{\circ} \mathrm{C}(948 \mathrm{~K})$ catalyst bed inlet temperature............................................ 27

Figure 4-1 Schematic View of Nuclear Heat Supply System............................................... 29

Figure 4-2 Three-Dimensional View of PBMR NGNP NHSS Design ................................. 29

Figure 4-3 Aspen Plus Flowsheet for PBMR NHSS Reference Design.................................. 31

Figure 5-1 HyS flowsheet using a PEM SDE and a bayonet decomposition reactor............ 43

Figure 5-2 Solubility of $\mathrm{SO}_{2}$ in sulfuric acid at 1.013-bar partial pressure - comparison of

OLI MSE model with data of Miles and Carson, Kuznetsov, and Miles and Fenton...... 47

Figure 5-3 Liquid-liquid phase equilibrium in the $\mathrm{SO}_{2}-\mathrm{H}_{2} \mathrm{O}$ system - comparison of OLI

MSE model with data of Maass and Maass, Spall, and van Diepen and Berkum ........... 48

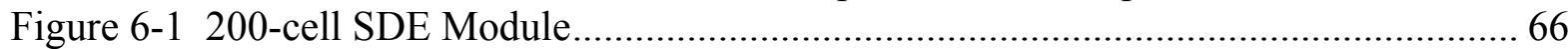

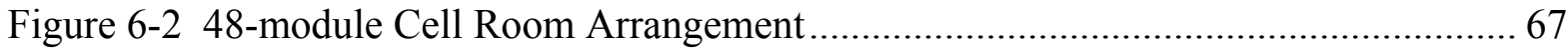

Figure 6-3 PBMR HyS Plant Schematic Configuration ...................................................... 70

Figure 7-1 $\mathrm{H}_{2}$ Price from SMR as a Function of Natural Gas Cost with Escalation .............. 89

Figure 7-2 Hydrogen Price from Electrolysis as a Function of Electricity Cost .................... 91

Figure 7-3 HyS Hydrogen Price and Baselines, All with Escalation ..................................... 98

Figure 7-4 Tornado Chart for HyS Capital Costs .............................................................. 101

Figure 7-5 Tornado Chart for HyS Other Than Capital Costs............................................. 102

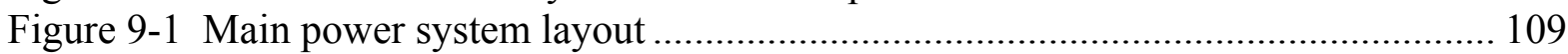

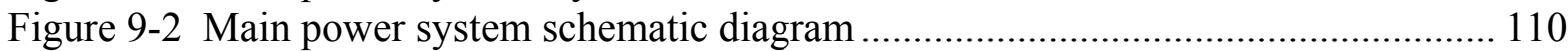

Figure 9-3 Fuel element design for PBMR .............................................................. 112

Figure 9-4 Performance of PBMR fuel under extended periods at high temperatures........ 115 Figure 9-5 Temperature of the hottest part of the fuel and overall average after a total loss of

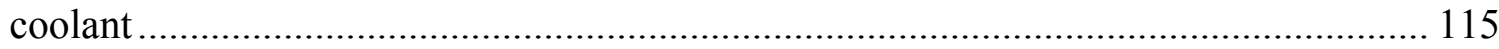

Figure 9-6 Main power system layout .......................................................................... 120

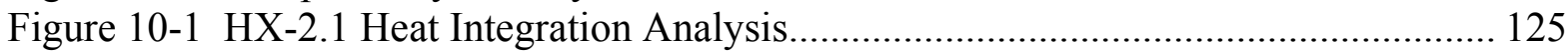

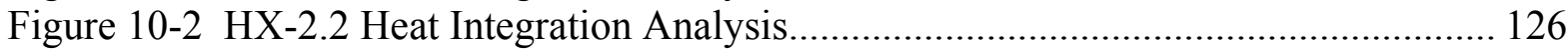

Figure 10-3 HX-2.3 Heat Integration Analysis.............................................................. 127 


\section{LIST OF TABLES}

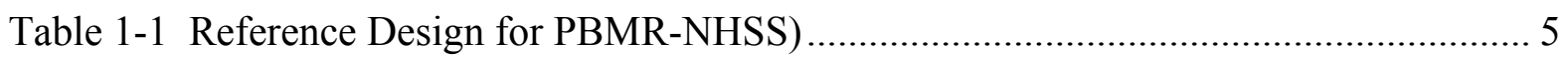

Table 1-2 PBMR/HyS Plant Performance Summary........................................................... 6

Table 1-3 Total Costs of PBMR HyS Water-Splitting Plant .................................................... 6

Table 1-4 Hydrogen Price Components Summary ………..................................................... 8

Table 3-1 Energy requirement allowances for the HyS process ............................................ 23

Table 4-1 PBMR-NHSS Reference Design Performance …………………………............. 35

Table 4-2 Primary He Coolant Stream Data for Reference Design Case ............................... 35

Table 4-3 Secondary He Coolant Stream Data for Reference Design Case .......................... 36

Table 4-4 Design Cases for Reference PBMR NHSS Flowsheet........................................... 37

Table 4-5 Performance Summary for the PBMR-NHSS Design Cases ................................ 38

Table 5-1 HyS flowsheet stream table .............................................................................. 44

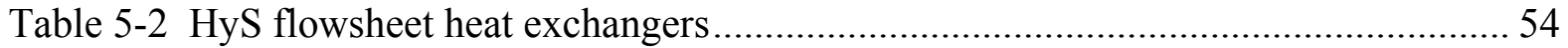

Table 5-3 HyS flowsheet electrolyzers, pumps, and compressors........................................ 55

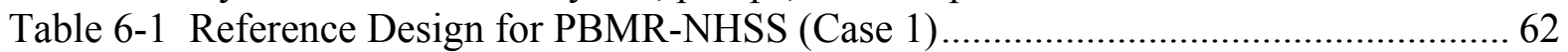

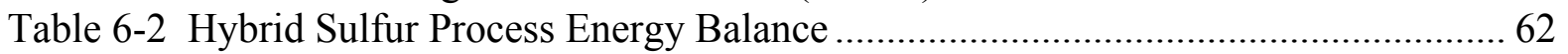

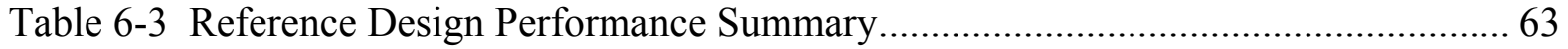

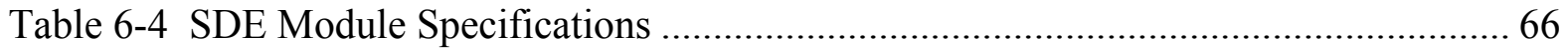

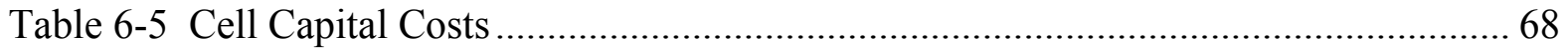

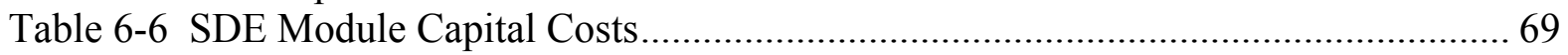

Table 6-7 Capital Cost Elements of PBMR HyS Water Splitting Plant................................. 72

Table 6-8 Total Costs of PBMR HyS Water-Splitting Plant .................................................. 74

Table 6-9 HyS plant direct costs evaluated by Aspen Icarus.............................................. 76

Table 6-10 Comparison between reference (Shaw) and alternative (Icarus) HyS plant direct

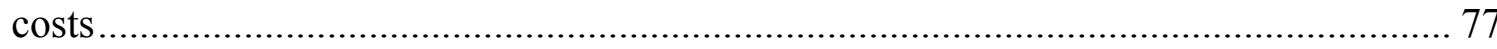

Table 6-11 Capital Replacement Costs of HyS Plant, per NHSS Unit.................................. 78

Table 6-12 Operating and Maintenance Costs of NHSS ……................................................ 79

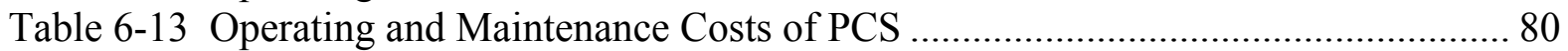

Table 6-14 Operating and Maintenance Costs of BOP........................................................ 81

Table 6-15 Operating and Maintenance Costs for the HyS Water Splitting Process System 82

Table 6-16 Operating and Maintenance Costs of HPS ……………………......................... 83

Table 6-17 Additional Cost Factors by Overall System ....................................................... 84

Table 6-18 Sum of Operating and Maintenance Costs for Plant ............................................. 85

Table 7-1 Hydrogen from Natural Gas by Advanced Steam Methane Reforming................ 89

Table 7-2 Hydrogen from Conventional Alkaline Electrolysis ............................................. 91

Table 7-3 Major Assumptions for Analysis of HyS Economics ............................................ 92

Table 7-4 Overall Cost and Performance Factors for Analysis ............................................. 93

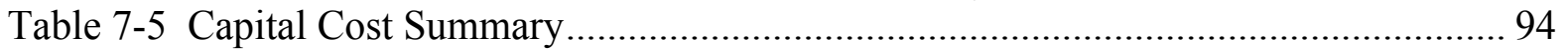

Table 7-6 Hydrogen Price Components Summary ………………………………................. 95

Table 7-7 Hydrogen Price Components Detail, $\$ / \mathrm{kg} \mathrm{H}_{2}$, Reference (Shaw) Basis ................ 96

Table 7-8 Hydrogen Price Components Detail, $\$ / \mathrm{kg} \mathrm{H}_{2}$, Alternative (Icarus) Basis ............. 97

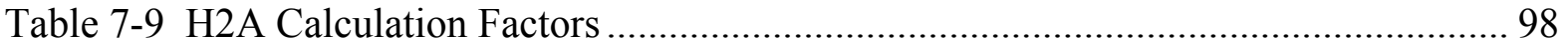

Table 7-10 Sensitivity Input Variables ........................................................................... 100

Table 10-1 HyS Process Heat Exchanger Summary and Energy Balance ......................... 128 
Table 11-1 Electrolysis Section Vessels/Reactors.......................................................... 130

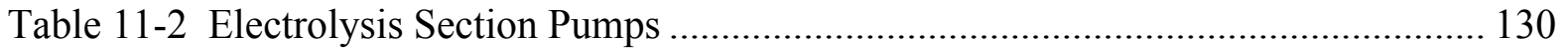

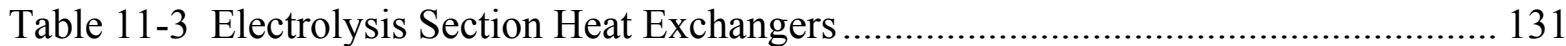

Table 11-4 Electrolysis Section Miscellaneous Equipment................................................... 131

Table 11-5 Sulfuric Acid Decomposition Section Towers ................................................... 132

Table 11-6 Sulfuric Acid Decomposition Section Vessels/Reactors................................... 132

Table 11-7 Sulfuric Acid Decomposition Section Pumps .................................................. 134

Table 11-8 Sulfuric Acid Decomposition Section Compressors/Blowers/Vacuum Pumps 134

Table 11-9 Sulfuric Acid Decomposition Section Heat Exchangers.................................. 135

Table 11-10 Feed and Utility Supply Section Vessels/Reactors ........................................ 136

Table 11-11 Feed and Utility Supply Section Low Pressure Tanks .................................... 137

Table 11-12 Feed and Utility Supply Section Pumps ........................................................ 137

Table 11-13 Feed and Utility Supply Section Miscellaneous Equipment ........................... 137

Table 11-14 Feed and Utility Supply Section Heat Exchangers............................................ 138

Table 11-15 Product Purification Section Towers............................................................. 138

Table 11-16 Product Purification Section Vessels/Reactors ............................................. 138

Table 11-17 Product Purification Section Pumps ............................................................. 139

Table 11-18 Product Purification Section Compressors/Blowers/Vacuum Pumps ............. 139

Table 11-19 Product Purification Section Heat Exchangers.................................................. 140

Table 12-1 Material Selection Table Based on Stream Analyses........................................ 142 


\section{LIST OF ACRONYMS}

\begin{tabular}{|c|c|}
\hline $\mathrm{ABB}$ & Asea Brown Boveri \\
\hline AVR & Arbeitsgemeinschaft Versuchsreaktor, GmbH (Germany) \\
\hline BNFL & British Nuclear Fuels, Ltd. \\
\hline BOP & Balance of Plant \\
\hline BWR-LS & Benedict-Webb-Rubin-Lee-Starling (equation of state in Aspen Plus) \\
\hline CEA & Commissariat à l'Energie Atomique (France) \\
\hline CVD & Chemical Vapor Deposition \\
\hline DEAT & Department of Environmental Affairs and Tourism (South Africa) \\
\hline DG & Director General \\
\hline DOE & Department of Energy (United States) \\
\hline DOE-NE & DOE Office of Nuclear Energy \\
\hline EIA & Environmental Impact Assessment \\
\hline GA & General Atomics \\
\hline HHV & Higher Heating Value \\
\hline HKG & Hochtemperatur-Kernkraftwerk, GmbH. (Germany) \\
\hline HPS & Hydrogen Production System \\
\hline HTF & Helium Test Facility \\
\hline HTGR & High-Temperature, Gas-cooled Reactor \\
\hline HTR & High Temperature Reactor \\
\hline HyS & Hybrid Sulfur \\
\hline IDC & Industrial Development Corporation (South Africa) \\
\hline IDC & Interest During Construction \\
\hline IHX & Intermediate Heat Exchanger \\
\hline ILS & Integrated lab-scale (experiment) \\
\hline ITGR & Intermediate temperature gas-cooled reactor \\
\hline LEU & Low enriched uranium \\
\hline LHV & Lower Heating Value \\
\hline LNG & Liquefied natural gas \\
\hline MEA & Membrane-electrode assembly \\
\hline MP & Medium pressure (steam) \\
\hline NGNP & Next Generation Nuclear Plant \\
\hline $\mathrm{NHI}$ & Nuclear Hydrogen Initiative \\
\hline NHSS & Nuclear Heat Supply System \\
\hline NNR & National Nuclear Regulator (South Africa) \\
\hline PBI & Polybenzimidazole \\
\hline PBMR & Pebble Bed Modular Reactor or Pebble Bed Modular Reactor (Pty) Ltd. \\
\hline PCDR & Pre-Conceptual Design Report \\
\hline PCHX & Process Coupling Heat Exchanger \\
\hline PCS & Power Conversion System \\
\hline PEM & Proton exchange membrane \\
\hline PHP & Process Heat Plant \\
\hline PHTS & Primary Heat Transport System \\
\hline PTFE & Polytetrafluoroethylene \\
\hline
\end{tabular}




$\begin{array}{ll}\text { PWR } & \text { Pressurized Water Reactor } \\ \text { RIT } & \text { Reactor inlet temperature } \\ \text { RoD } & \text { Record of Decision } \\ \text { RPV } & \text { Reactor Pressure Vessel } \\ \text { RSA } & \text { Republic of South Africa } \\ \text { SAD } & \text { Sulfuric Acid Decomposition } \\ \text { SAR } & \text { Safety Analysis Report } \\ \text { SDAPP } & \text { Sulfonated Diels Alder Polyphenylene } \\ \text { SDE } & \text { SO2-depolarized electrolyzer } \\ \text { SG } & \text { Steam Generator } \\ \text { SHTS } & \text { Secondary Heat Transport System } \\ \text { SI } & \text { Sulfur-Iodine } \\ \text { SiC } & \text { Silicon carbide } \\ \text { SMR } & \text { Steam methane reforming } \\ \text { SNG } & \text { Synthetic natural gas } \\ \text { SNL } & \text { Sandia National Laboratories } \\ \text { SRNL } & \text { Savannah River National Laboratory } \\ \text { TCA } & \text { Technical Consulting Agreement } \\ \text { THTR } & \text { Thorium High Temperature Reactor } \\ \text { TRISO } & \text { Triple-coated isotropic } \\ \text { U-235 } & \text { Uranium-235 isotope } \\ \text { UK } & \text { United Kingdom } \\ \text { US } & \text { United States } \\ \text { USC } & \text { University of South Carolina } \\ \text { USSR } & \text { Union of Soviet Socialist Republics } \\ \text { VHTR } & \text { Very High Temperature Reactor } \\ & \end{array}$




\subsection{EXECUTIVE SUMMARY}

This report documents a detailed study to determine the expected efficiency and product costs for producing hydrogen via water-splitting using energy from an advanced nuclear reactor. It was determined that the overall efficiency from nuclear heat to hydrogen is high, and the cost of hydrogen is competitive under a high energy cost scenario. It would require over $40 \%$ more nuclear energy to generate an equivalent amount of hydrogen using conventional water-cooled nuclear reactors combined with water electrolysis compared to the proposed plant design described herein.

There is a great deal of interest worldwide in reducing dependence on fossil fuels, while also minimizing the impact of the energy sector on global climate change. One potential opportunity to contribute to this effort is to replace the use of fossil fuels for hydrogen production by the use of water-splitting powered by nuclear energy. Hydrogen production is required for fertilizer (e.g. ammonia) production, oil refining, synfuels production, and other important industrial applications. It is typically produced by reacting natural gas, naphtha or coal with steam, which consumes significant amounts of energy and produces carbon dioxide as a byproduct. In the future, hydrogen could also be used as a transportation fuel, replacing petroleum. New processes are being developed that would permit hydrogen to be produced from water using only heat or a combination of heat and electricity produced by advanced, high temperature nuclear reactors. The U.S. Department of Energy (DOE) is developing these processes under a program known as the Nuclear Hydrogen Initiative (NHI).

The Republic of South Africa (RSA) also is interested in developing advanced high temperature nuclear reactors and related chemical processes that could produce hydrogen fuel via water-splitting. This report focuses on the analysis of a nuclear hydrogen production system that combines the Pebble Bed Modular Reactor (PBMR), under development by PBMR (Pty.) Ltd. in the RSA, with the Hybrid Sulfur (HyS) Process, under development by the Savannah River National Laboratory (SRNL) in the US as part of the NHI. This work was performed by SRNL, Westinghouse Electric Company, Shaw, PBMR (Pty) Ltd., and Technology Insights under a Technical Consulting Agreement (TCA). Westinghouse Electric, serving as the lead for the PBMR process heat application team, established a costshared TCA with SRNL to prepare an updated HyS thermochemical water-splitting process flowsheet, a nuclear hydrogen plant preconceptual design and a cost estimate, including the cost of hydrogen production. SRNL was funded by DOE under the NHI program, and the Westinghouse team was self-funded. The results of this work are presented in this Final Report. Appendices have been attached to provide a detailed source of information in order to document the work under the TCA contract.

Thermochemical water-splitting cycles consist of a series of linked chemical reactions which result in the dissociation of water molecules into hydrogen and oxygen. All of the intermediate chemicals are regenerated and the only consumable is water. When nuclear 
power is used to provide the high temperature thermal energy, hydrogen is produced without production of greenhouse gases or other air pollutants. Pure thermochemical cycles require heat only to drive a series of connected chemical reactions, whereas hybrid cycles employ at least one electrochemical step. The SRNL has been tasked by DOE with the primary responsibility to perform research and development in order to characterize, evaluate and develop the HyS thermochemical process. The HyS Process uses a sulfur dioxide $\left(\mathrm{SO}_{2}\right)$ depolarized electrolyzer (SDE) to split water and produce hydrogen. High temperature heat is used in an Acid Decomposer to dissociate sulfuric acid and recycle the $\mathrm{SO}_{2}$. The HyS Process has the potential for high efficiency, competitive cost of hydrogen, and it has been demonstrated at a laboratory scale to confirm performance characteristics. It is the simplest all-fluid thermochemical cycle.

The HyS Process is a leading candidate among thermochemical cycles for coupling with a High Temperature Gas-cooled Reactor (HTGR). The PBMR, under development in South Africa, is ideally suited for this application. Pre-conceptual work has confirmed that the PBMR design can be readily integrated into process heat applications. The characteristic robustness and flexibility of the core design means that only minimal modifications to interfaces are necessary to meet to broad range of process heat application requirements. Following a review of the leading options for nuclear water splitting, the PBMR-based team selected the HyS process as the current preferred reference. The integration of the PBMR heat and power source with the HyS hydrogen production process is the subject of this report.

The HyS cycle was first proposed by Westinghouse Electric Co, where it was known as the Westinghouse Sulfur cycle and was extensively developed in the 1970s and 1980s. HyS is one of the simplest thermochemical cycles, comprising only two reaction steps and having only fluid reactants. The "hybrid" designation acknowledges the electrochemical nature of one of the reaction steps, which requires that electric as well as thermal energy be supplied to the process. A simple schematic showing the reaction steps is shown in Figure 1-1.

A major challenge for the HyS Process is the development of an efficient, cost-effective electrochemical reactor, or SDE ( $\mathrm{SO}_{2}$-depolarized electrolyzer). The SRNL is leading efforts supported by the DOE NHI to develop the SDE. In contrast to previous efforts to develop an SDE, SRNL has based its work on the use of proton exchange membrane (PEM) technology. The advantages of this design concept include high electrochemical efficiency, small footprint, and potential for competitive capital cost, all of which are crucial for successful implementation on a commercial scale. Since PEM technology is also the subject of intense development efforts for use in water electrolyzers and automotive fuel cells, there is the opportunity for leveraging that work for improving the SDE. The application is challenging, however, since the SDE must react $\mathrm{SO}_{2}$ with water to produce hydrogen in the presence of strong sulfuric acid under elevated temperature and pressure. SRNL has successfully built and tested both single cell and multi-cell stacks for the SDE application using PEM technology. A conceptual design and cost estimate for a commercial SDE have been developed and are discussed in detail in the report. 
Inputs:

- Water

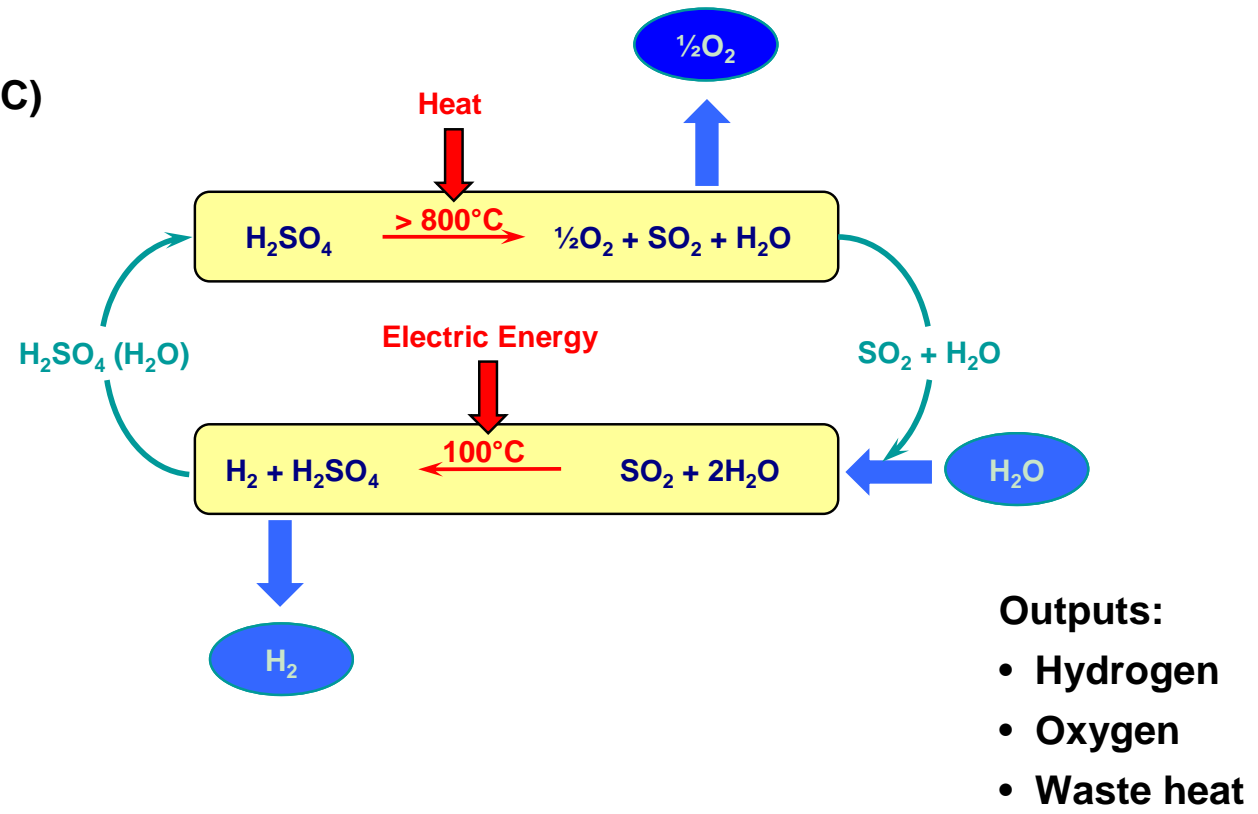

- Heat $\left(>800^{\circ} \mathrm{C}\right)$

- Electricity

Figure 1-1 Hybrid Sulfur (HyS) Cycle Reaction Steps

The second step in the HyS Process involves the thermal decomposition of sulfuric acid using heat from the nuclear reactor. One of the most difficult challenges in decomposing sulfuric acid at high temperatures $\left(>800^{\circ} \mathrm{C}\right)$ and pressures (up to 90 bar) is finding a material that can contain the process at the required conditions without significantly corroding or deteriorating, while providing adequate heat transfer characteristics. Silicon carbide $(\mathrm{SiC})$ is among the handful of substances identified so far that meet these requirements. The Sandia National Laboratory (SNL), as part of the NHI program, has devised an innovative solution that makes use of readily available $\mathrm{SiC}$ shapes and does not have any high-temperature connections. Their bayonet decomposition reactor features internal recuperation and allows all of the connections to be made at relatively low temperatures, where polytetrafluoroethylene (PTFE) and similar materials can be used for seals. The bayonet acid decomposer approach was used as the basis of the HyS process design for this study.

The Reference Design documented by this report features indirect heating of the hightemperature Sulfuric Acid Decomposition Reactor by a secondary helium (He) coolant loop between the primary He heat transfer loop and the HyS Process. This provides separation between the nuclear heat supply facility and the hydrogen production plant. The basic configuration for integrating the PBMR and the HyS hydrogen plant is illustrated in Figure 1-2. Details of the energy balance, including estimates of helium flow rates, pressure drops, etc., for this configuration are given in the report. The major results are shown in Table 1-1. 


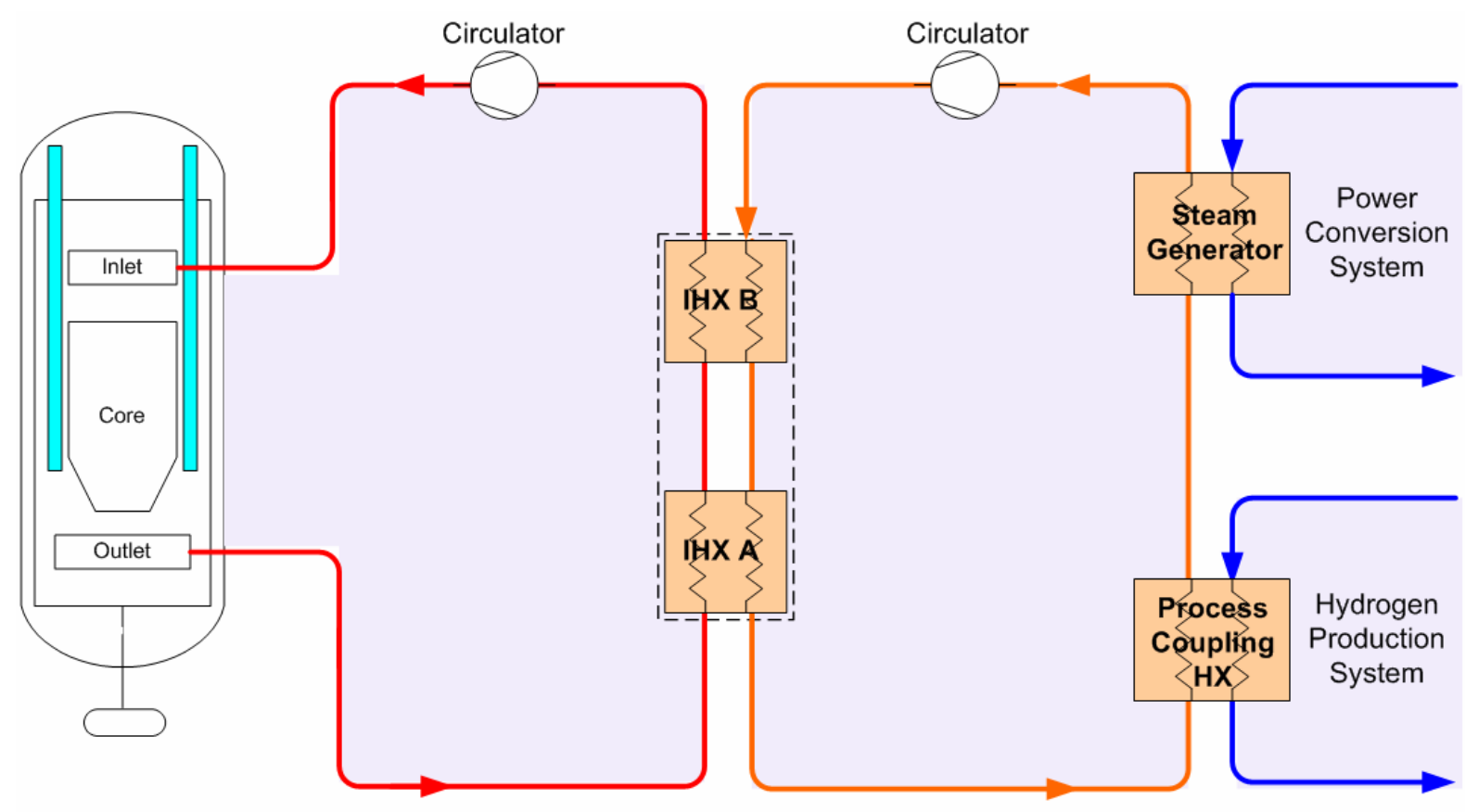

Figure 1-2 Schematic View of Nuclear Heat Supply System

Improvements in the HyS flowsheet and optimization of the reactor/process integration based on maximizing hydrogen production from the plant resulted in a hydrogen production from a single PBMR of 160 metric tons per day (MT/day). This compares to $63 \mathrm{MT} /$ day for the previous baseline process heat design developed by PBMR and Westinghouse. The new design represents over $150 \%$ more hydrogen production per reactor, although it results in less process heat for steam or electricity production.

The benchmark against which the PBMR/HyS system will frequently be judged is the use of conventional nuclear power generation coupled with water electrolysis. Since these are proven technologies that could be deployed almost immediately, the more complex PBMR/HyS system needs to provide a significant advantage in terms of higher process thermal efficiency in order to overcome development risk and expected higher initial capital costs. The results of this study indicate that this is the case. Detailed analysis was performed to determine both the HyS process efficiency, as well as the preferred integrations between the HyS process and the PBMR system. The overall process efficiency for the PBMR/HyS system is estimated to by $36.7 \%$ based on the higher heating value of the hydrogen product. The results are shown in Table 1-2. This compares to an estimated efficiency of $25-27 \%$ for an LWR combined with conventional water electrolysis. This means that it would require over $40 \%$ more nuclear energy to generate an equivalent amount of hydrogen using conventional water-cooled nuclear reactors combined with water electrolysis compared to the proposed PBMR/HyS plant design described herein. 
Table 1-1 Reference Design for PBMR-NHSS)

\begin{tabular}{|c|c|}
\hline PBMR power level, $\mathrm{MW}_{\text {th }}$ & 500 \\
\hline Hydrogen production rate, $\mathrm{kmol} / \mathrm{hr}$ & 3309 \\
\hline Hydrogen production rate, MT/day & 160 \\
\hline \multicolumn{2}{|l|}{ Primary Helium Conditions } \\
\hline He flow rate, $\mathrm{kg} / \mathrm{s}$ & 160 \\
\hline He flow rate at reactor outlet, $\mathrm{m}^{3} / \mathrm{s}$ & 47 \\
\hline Pressure, circulator outlet, $\mathrm{MPa}$ & 9.0 \\
\hline Temperature, $\mathrm{PBMR}$ inlet, ${ }^{\circ} \mathrm{C}$ & 350 \\
\hline Temperature, PBMR outlet, ${ }^{\circ} \mathrm{C}$ & 950 \\
\hline \multicolumn{2}{|l|}{ Secondary Helium Temperatures, ${ }^{\circ} \mathrm{C}$} \\
\hline He flow rate, $\mathrm{kg} / \mathrm{s}$ & 160 \\
\hline Pressure, circulator outlet, $\mathrm{MPa}$ & 9.3 \\
\hline Temperature, IHX inlet, ${ }^{\circ} \mathrm{C}$ & 287 \\
\hline Temperature, IHX outlet, ${ }^{\circ} \mathrm{C}$ & 900 \\
\hline Temperature, $\mathrm{PCHX}$ inlet, ${ }^{\circ} \mathrm{C}$ & 900 \\
\hline Temperature, $\mathrm{PCHX}$ outlet, ${ }^{\circ} \mathrm{C}$ & 523 \\
\hline \multicolumn{2}{|l|}{ Acid Decomposer Conditions } \\
\hline Pressure, $\mathrm{MPa}$ & 8.6 \\
\hline Peak temperature, ${ }^{\circ} \mathrm{C}$ & 870 \\
\hline PCHX heat duty, $\mathrm{MW}_{\text {th }}$ & 313 \\
\hline \multicolumn{2}{|l|}{ Other Major Components } \\
\hline Steam Generator heat duty, $\mathrm{MW}_{\mathrm{th}}$ & 204 \\
\hline Primary Circulator power, $\mathrm{MW}_{\mathrm{e}}$ & 12 \\
\hline Secondary Circulator power, $\mathrm{MW}_{\mathrm{e}}$ & 9 \\
\hline
\end{tabular}

A capital cost estimate and cost-of-hydrogen estimate were made for the reference plant design. The HyS plant components were selected and sized in detail on the basis of the process flowsheet and the physical properties of the process streams. The available output data was suitably modified to get input for the component sizing process. Only commercially existing equipment was chosen, other than the Sulfuric Acid Decomposition Reactor and the SDE modules, which are technology in development. Costs for the PBMR and associated NHSS equipment were based on previous estimates prepared by the Westinghouse/PBMR team. For the analysis of hydrogen selling price, a mature, four-PBMR unit hydrogen plant is modeled, in order to represent the full commercial potential of the application. Economies derive from sharing of facilities and other cost savings that would come from a mature supply infrastructure. The results are given for a four-unit plant and a "nominal" one-unit plant (where the one-unit plant still has the four-unit economies). Total costs for a PBMR/HyS water-splitting plant are shown in Table 1-3. 
Table 1-2 PBMR/HyS Plant Performance Summary

\begin{tabular}{|c|c|}
\hline PBMR Power Rating, $M_{\text {th }}$ & 500 \\
\hline \multicolumn{2}{|l|}{ Hydrogen Output } \\
\hline Mass flow rate, MT/day & 160.1 \\
\hline Thermal value (HHV), $\mathrm{MW}_{\text {th }}$ & 262.8 \\
\hline \multicolumn{2}{|l|}{ Thermal Energy Requirements, $\mathbf{M W}_{\text {th }}$} \\
\hline High-temperature heat to Decomposition & 312.8 \\
\hline Steam to acid concentration & 70.6 \\
\hline Steam for power generation & 132.9 \\
\hline \multicolumn{2}{|l|}{ Electric Power Requirements, $\mathrm{MW}_{\mathrm{e}}$} \\
\hline Helium circulators & 20.3 \\
\hline HyS electrolyzer power supply (AC) & 110.8 \\
\hline HyS pumps, circulators, etc. & 4.7 \\
\hline NHSS, PGS and BOP ${ }^{1}$ & 8.2 \\
\hline Total electric demand & 144.0 \\
\hline Onsite power generation & 54.8 \\
\hline Net electric power from grid & 89.2 \\
\hline \multicolumn{2}{|l|}{ Overall Plant Efficiency } \\
\hline Reactor thermal input, $\mathrm{MW}_{\text {th }}$ & 500.0 \\
\hline Thermal equivalent of import electricity, ${ }^{2} \mathrm{MW}_{\text {th }}$ & 216.5 \\
\hline Total thermal input, $\mathrm{MW}_{\text {th }}$ & 716.5 \\
\hline Overall plant efficiency (HHV basis) & 36.7 \\
\hline
\end{tabular}

Notes:

${ }^{1} \mathrm{NHSS}=5.6 \mathrm{MW}_{\mathrm{e}} ; \mathrm{PGS}=1.2 \mathrm{MW}_{\mathrm{e}} ; \mathrm{BOP}=1.4 \mathrm{MW}_{\mathrm{e}}$. Based on "NGNP and Hydrogen Production Preconceptual Design Report, Section 8: Power Conversion Systems, NGNP-08-RPT-001”, Westinghouse Electric Company, May 2007, Table 8-17.

${ }^{2}$ Assumes $41.2 \%$ thermal-to-electric conversion efficiency

Table 1-3 Total Costs of PBMR HyS Water-Splitting Plant

\begin{tabular}{|l|c|c|c|}
\cline { 2 - 4 } \multicolumn{1}{c|}{} & $\begin{array}{c}\text { Total for 4- } \\
\text { unit } 2000- \\
\text { MW }_{\text {th }} \text { NHSS }\end{array}$ & $\begin{array}{c}\text { Total Costs } \\
\text { per NHSS } \\
\text { Unit }\end{array}$ & $\begin{array}{c}\text { Specific Cost / Unit } \\
\text { Cost }\end{array}$ \\
\hline Total Direct Depreciable Cost & $\$ 4,432 \mathrm{M}$ & $\$ 1,108 \mathrm{M}$ & -- \\
\hline Indirect (Owners' and Other) Costs & $\$ 77.9 \mathrm{M}$ & $\$ 19.5 \mathrm{M}$ & -- \\
\hline Total Base Construction Cost & $\$ 4,510 \mathrm{M}$ & $\$ 1,128 \mathrm{M}$ & $\$ 2,200 / \mathrm{kW}_{\text {th }}$ \\
\hline Contingency & $\$ 443.2 \mathrm{M}$ & $\$ 110.8 \mathrm{M}$ & -- \\
\hline Land & $\$ 2.0 \mathrm{M}$ & $\$ 0.5 \mathrm{M}$ & $\$ 5,000 /$ acre \\
\hline Total Overnight Capital Cost & $\$ 4,962 \mathrm{M}$ & $\$ 1,240 \mathrm{M}$ & $\begin{array}{c}\$ 2,500 / \mathrm{kW}_{\text {th }} \\
\$ 7,700 / \mathrm{kg} / \mathrm{day} \\
\$ 5,600 / \mathrm{kW}\end{array} \mathrm{H}_{2}$ (LHV) \\
\hline
\end{tabular}


The cost-of-hydrogen for the plant was determined based on a specific tool for the comparison of hydrogen production technologies developed by DOE. This is a result of the H2A Production Analysis Program, which is part of the national Hydrogen Fuel Initiative, and which was conducted by a team from the various DOE divisions, the national laboratories and industrial participants. The H2A tool was therefore used as the basis for the hydrogen price calculations in this study.

The results for the PBMR/HyS reference design are shown in Table 1-4. The results are given for both a base case (Shaw) and a case labeled "Icarus". The base case uses capital cost estimates for the HyS plant as determined by Shaw using their in-house estimating program which draws data from recent purchasing. The Shaw estimate was prepared by an experienced professional estimator and equipment size estimated by an experienced process engineer. The Icarus case uses HyS capital costs, which are significantly less, determined by SNRL using a commercial cost estimating program. Although somewhat less rigorous than the Shaw estimate, the Icarus estimate is more consistent with other thermochemical hydrogen plant cost estimates that have been published. One reason for the higher costs estimated by Shaw was the use of equipment and commodity costs taken at a time (2nd Quarter 2008) at which industrial commodities were at a peak, which have since retreated. A second factor is that there is no specific industry experience with HyS or other large-scale plants for similar production of pure hydrogen. For this second reason, subjective factors in the cost estimating process are unavoidable, and in accounting for unknowns there is a natural tendency to be conservative.

The effects on hydrogen price were calculated for uncertainties in major parts of the costs, including capital cost factors and other factors, such as rate of return, power costs, etc. The base case using the Shaw estimates for the HyS equipment resulted in a levelized hydrogen price of $\$ 6.18 / \mathrm{kg} \mathrm{H}_{2}$. The sensitivity analysis showed a price range from $\$ 5.00$ to $\$ 7.10 / \mathrm{kg}$ $\mathrm{H}_{2}$. When the SRNL/Icarus equipment costs were used for the HyS plant, the levelized hydrogen price was $\$ 5.34 / \mathrm{kg} \mathrm{H}_{2}$, and the sensitivity range was $\$ 4.15$ to $\$ 6.25 / \mathrm{kg} \mathrm{H}_{2}$.

Analysis was also performed to determine how the projected hydrogen costs compared to hydrogen produced by conventional natural gas steam reforming and water electrolysis. At the presently estimated base case costs, according to the $\mathrm{H} 2 \mathrm{~A}$ model with the assumptions and groundrules as stated in this report, the hybrid sulfur nuclear water splitting plant competes with natural gas at a gas price of $\$ 16 / \mathrm{MMBtu}$ and with electrolysis at between $\$ 60$ and $\$ 70 / \mathrm{MW}_{\mathrm{e}}-\mathrm{hr}$. Using the Icarus-based process costs, the competitive range is approximately $\$ 13 / \mathrm{MMBtu}$ natural gas price and between $\$ 50$ and $\$ 60 / \mathrm{MW}_{\mathrm{e}}-\mathrm{hr}$ for electrolysis. These represent a high energy cost scenario, but they are not an unreasonable expectation. 
Table 1-4 Hydrogen Price Components Summary

\begin{tabular}{|c|c|c|c|c|}
\hline & $\begin{array}{c}\$ / \mathrm{kg} \\
(\mathrm{Shaw})\end{array}$ & $\begin{array}{c}\% \\
(\text { Shaw })\end{array}$ & $\begin{array}{c}\$ / \mathrm{kg} \\
\text { (Icarus) }\end{array}$ & $\begin{array}{c}\% \\
\text { (Icarus) }\end{array}$ \\
\hline Capital Charge & 4.01 & 65 & 3.19 & 59 \\
\hline $\begin{array}{l}\text { Fixed O\&M: } \\
\text { Labor, Taxes, Insurance, Annual Licensing, } \\
\text { Permits and Fees, Material Costs for Maintenance } \\
\text { And Repairs, Nuclear Decommissioning Funding, } \\
\text { Helium Make-up }\end{array}$ & 0.68 & 11 & 0.68 & 13 \\
\hline $\begin{array}{l}\text { Variable O\&M: } \\
\text { Nuclear Fuel, Process Catalyst and Chemical } \\
\text { Consumption and Waste Disposal }\end{array}$ & 0.56 & 9 & 0.56 & 11 \\
\hline $\begin{array}{l}\text { Utilities and Feed: } \\
\text { Electric Power and Process Water }\end{array}$ & 1.23 & 20 & 1.22 & 23 \\
\hline Byproduct Credit $\left(\mathrm{O}_{2}\right)$ & -0.32 & -5 & -0.32 & -6 \\
\hline Total Hydrogen Cost (Year 2008 Real \$/kg) & 6.18 & 100 & 5.34 & 100 \\
\hline
\end{tabular}




\subsection{INTRODUCTION}

Hydrogen has been identified as a leading candidate to replace petroleum as part of the transition to a sustainable energy system, and major efforts are being conducted worldwide to develop the technologies and supporting activities required for this transition. In the United States, the federal research efforts are led by the US Department of Energy (DOE). The US DOE Hydrogen Program is an integrated inter-office program being conducted by the Office of Energy Efficiency and Renewable Energy, Office of Nuclear Energy (DOE-NE), Office of Fossil Energy and Office of Science. The primary objective of the DOE-NE Nuclear Hydrogen Initiative (NHI) is to develop the nuclear hydrogen production technologies necessary to produce hydrogen at a cost competitive with other alternative transportation fuels while minimizing or eliminating the production of greenhouse gases. The focus of the $\mathrm{NHI}$ is on thermochemical cycles and high temperature electrolysis that can be powered by heat from high temperature gas reactors.

The Republic of South Africa (RSA) also is interested in developing advanced high temperature nuclear reactors and related chemical processes that could produce hydrogen fuel via water-splitting. This report focuses on the analysis of a nuclear hydrogen production system that combines the Pebble Bed Modular Reactor, under development by PBMR (Pty.) Ltd. in the RSA, with the Hybrid Sulfur Process, under development by SRNL in the US. The work was performed under a TCA between SRNL and Westinghouse Electric, who is the lead for the PBMR team. SRNL was funded by DOE under the NHI program and the Westinghouse team was self-funded.

Thermochemical water-splitting cycles consist of a series of linked chemical reactions which result in the dissociation of water molecules into hydrogen and oxygen. All of the intermediate chemicals are regenerated and the only consumable is water. When nuclear power is used to provide the high temperature thermal energy, hydrogen is produced without production of greenhouse gases or other air pollutants. Pure thermochemical cycles require heat only to drive a series of connected chemical reactions, whereas hybrid cycles employ at least one electrochemical step. The SRNL has been tasked with the primary responsibility to perform research and development in order to characterize, evaluate and develop the HyS thermochemical process. The HyS Process uses a sulfur dioxide $\left(\mathrm{SO}_{2}\right)$-depolarized electrolyzer (SDE) to split water and produce hydrogen.

The HyS Process is a leading candidate among thermochemical cycles for coupling with a High Temperature Gas-cooled Reactor (HTGR). The PBMR is ideally suited for this application. The HyS Process has the potential for high efficiency, competitive cost of hydrogen, and it has been demonstrated at a laboratory scale to confirm performance characteristics. It is the simplest all-fluid thermochemical cycle. 
SRNL has collaborated with Westinghouse Electric and Shaw to upgrade the HyS flowsheet and process design and to prepare a capital cost estimate. PBMR and Technology Insights have also provided significant input in the plant design and cost estimates. The results of this work are presented in this Final Report. Appendices have been attached to provide a detailed source of information in order to document the work under this TCA.

The background on nuclear hydrogen production, the PBMR and the HyS Process are presented in Section 3.0. A discussion of the PBMR-HyS process interface is given in Section 4.0. The HyS process flowsheet is presented in Section 5.0. The overall nuclear hydrogen plant conceptual design and cost estimate is discussed in Section 6.0. The cost of hydrogen and comparison with alternatives are discussed in Section 7.0. 


\subsection{BACKGROUND}

\subsection{NUCLEAR HYDROGEN PRODUCTION}

There is currently a great deal of interest in the transition from our present petroleum-based transportation system to a new energy system based on hydrogen. A significant "Hydrogen Economy" is envisioned that could reduce our dependence on petroleum imports and reduce pollution and greenhouse gas emissions. Hydrogen is an environmentally attractive fuel that has the potential to displace fossil fuels, but hydrogen is an energy carrier, not an energy source. While hydrogen is the most plentiful element in the universe, it is not found in the free state in appreciable quantities on earth. Nearly all hydrogen is chemically bound as water, hydrocarbons, carbohydrates or other compounds. Energy must be invested to separate the hydrogen into a pure element.

Hydrogen is now produced for use in manufacture of fertilizers, in oil refineries to lighten heavy crude oils and produce clearer-burning fuels, and for other industrial uses, primarily by steam reformation of methane. Transition to a Hydrogen Economy will require significant expansion in the production of hydrogen - a factor of $\sim 15$ more for transportation energy alone. Clearly, new sources of hydrogen will be needed. Hydrogen produced from water using nuclear energy can be one of the sources, and would avoid both use of fossil fuels and greenhouse gas emissions.

Hydrogen could be produced from nuclear energy by several means. Electricity from nuclear power can separate water into hydrogen and oxygen by electrolysis. Low temperature electrolysis is a proven, commercial technology. However, the net efficiency is the product of the efficiency of the reactor in producing electricity times the efficiency of the electrolysis cell, resulting in an overall efficiency of approximately $24 \%$ (HHV basis) when using Light Water Reactors for electricity production. Somewhat higher efficiency could be possible if the electricity were generated using a high temperature gas reactor and a direct Brayton gas turbine cycle. If the electrolysis were done using steam at high temperature, nuclearproduced heat from gas reactors could be substituted for some of the electricity and the net heat-to-hydrogen efficiency could be increased to as much as $35-40 \%$ (HHV basis).

Thermochemical water-splitting cycles could get all or nearly all of their input energy from nuclear-produced heat, using coupled, thermally-driven chemical reactions to split water into oxygen and hydrogen. Thermochemical cycles also offer the promise of heat-to-hydrogen efficiencies of $35-40 \%$ (HHV basis).

Efforts are underway in several countries to develop both the high temperature nuclear reactors and the hydrogen production processes to permit water-splitting using nuclear energy. In the United States, the US DOE Office of Nuclear Energy is supporting research to development processes for producing hydrogen from advanced nuclear reactors in the NHI program. The primary objective of the NHI is to develop the nuclear hydrogen production 
technologies necessary to produce hydrogen at a cost competitive with other alternative transportation fuels. The focus of the program is on thermochemical cycles and high temperature electrolysis. In addition, the DOE program is developing several critical technologies that support these efforts, including development of advanced ceramic membranes for improved hydrogen process separations and innovative high temperature heat exchanger designs and materials for use in advanced thermochemical cycles. The NHI works in conjunction with the Next Generation Nuclear Plant (NGNP) project, which is focused on developing Generation IV nuclear reactors.

The production of hydrogen for the "Hydrogen Economy" is a major goal of nuclear hydrogen production programs. However, it is recognized that the commercial application of such processes is somewhat in the future. In the nearer term, hydrogen is in increasing demand for upgrading heavier petroleum resources, metals processing and other industrial applications. Most of this hydrogen relies on natural gas as the feedstock and energy source. In the future, the rate of natural gas use will increase even faster as heavier hydrocarbons such as oil shale, oil sands and coal are processed for transportation fuels. Meanwhile, natural gas is becoming the fossil fuel of choice to minimize $\mathrm{CO}_{2}$ and other emissions in other energy sectors such as power generation. As a result, natural gas has become more expensive. Producing hydrogen using nuclear energy can cap the cost at competitive rates, reduce global greenhouse gas emissions and the national security consequences of reliance on foreign petroleum and LNG imports.

\subsection{PEBBLE BED MODULAR REACTOR}

The Pebble Bed Modular Reactor (PBMR), under development in South Africa, is a high temperature, gas-cooled reactor (HTGR). A detailed discussion of the PBMR is given in Appendix 9.0.

The development of advanced higher temperature nuclear reactors creates the means to expand the use of nuclear energy into a variety of industrial and transport sectors (in addition to electricity generation), by supplying clean process heat to produce chemical products, liquid petroleum fuels and hydrogen. The nuclear heat source must still meet modern reactor design standards, be economic, match the process technical needs and reliably produce the required temperatures.

South Africa's PBMR technology fits each of these requirements. Because of its very high reactor outlet temperatures of up to $950^{\circ} \mathrm{C}$, the heat from the PBMR can be applied for a variety of industrial process applications. For example, the PBMR produced steam can be used to extract oil from oil sands, and for many other petrochemical industrial applications where fossil fuels are currently used as the primary source of process steam. Alternatively, the PBMR produced hydrogen can be used for upgrading coal and heavy crude oils into usable products or for transportation fuel in the future, thereby relieving pressure on natural gas supply (the source of most hydrogen produced today). 
These applications are under investigation with potential customers in global markets by the PBMR based team of PBMR (Pty) Ltd., Westinghouse and Shaw. Pre-conceptual work has confirmed that the PBMR can be readily integrated into process heat applications. The characteristic robustness and flexibility of the core design means that only minimal modifications to interfaces are necessary to meet to broad range of process heat application requirements.

\subsubsection{PBMR Product Range}

The South African PBMR project entails the design development of a Nuclear Heat Supply System (NHSS) and a fuel plant at Pelindaba near Pretoria. The NHSS will adapt to a broad range of Process Heat Plants (PHPs).

The PHPs are intended to operate at power levels of up to $500 \mathrm{MW}_{\text {th }}$ with reactor outlet temperatures up to $950^{\circ} \mathrm{C}$. Process steam delivery is the near-term entry market application with hydrogen delivery as the follow-on. Hence, development work is focused on two time frames and technology windows:

- Applications operating at reactor outlet temperatures less than $800^{\circ} \mathrm{C}$ to produce high-pressure steam and cogeneration. Component engineering development requirements and application integration engineering requirements are such that deployment in the latter part of the next decade will be feasible.

- The follow-on development phase, focusing on the end of the next decade and early 2020s, will meet the requirements for operating at reactor outlet temperatures up to $950^{\circ} \mathrm{C}$. This phase matches timeframes for associated developments in high-temperature materials and hydrogen production processes including thermo-chemical water-splitting processes.

\subsubsection{Value Proposition}

Attractive applications for nuclear process heat are driven primarily by the opportunity to displace natural gas and other premium fuels, and to respond to incentives to reduce $\mathrm{CO}_{2}$ emissions. Even with conservatively low forecasts for growth in long-term gas prices, clear commercial benefit exists in reducing exposure to the volatility and insecurity of single sources of energy supply. Economic assessments of PBMR process heat applications, based on current trends, indicate that the PBMR will be competitive in many markets, especially markets with high premium fuel costs and $\mathrm{CO}_{2}$ emission constraints.

\subsubsection{Projects Update}

In the USA, PBMR (Pty) Ltd. Westinghouse and Shaw are the lead principals in a world class team advancing the NGNP Project, which is based on developing and demonstrating HTGR technology for a broad range of industrial process heat applications, including hydrogen production. Application studies, conducted with potential industry users for the 
PBMR technology, serve to advance Project definition and the bases for commitment by all stakeholders.

\subsubsection{PBMR Hydrogen Production}

Following a review of the leading options for nuclear water splitting, the PBMR-based team selected the HyS process as the current preferred reference. The integration of the PBMR heat and power source with the HyS hydrogen production process is discussed in the remainder of this report.

\subsection{THE HYBRID SULFUR CYCLE}

The HyS cycle was first proposed by Brecher and $\mathrm{Wu}$ [1] at Westinghouse Electric., where it was developed in the 1970s and 1980s $[2,3,4]$. As a result, it has also come to be known as the Westinghouse process [5]. HyS is one of the simplest thermochemical cycles, comprising only two reaction steps and having only fluid reactants. The "hybrid" designation acknowledges the electrochemical nature of one of the reaction steps, which requires that electric as well as thermal energy be supplied to the process. It is a sulfur cycle because it entails sulfur oxidation and reduction. In fact, sulfur is the only element in the cycle other than $\mathrm{H}_{2}$ and oxygen $\left(\mathrm{O}_{2}\right)$.

A simple schematic of the HyS cycle that illustrates the two reaction steps and how they interact to split water is shown in Figure 3-1. The first step,

$$
\mathrm{H}_{2} \mathrm{SO}_{4} \leftrightarrow \mathrm{H}_{2} \mathrm{O}+\mathrm{SO}_{2}+1 / 2 \mathrm{O}_{2}
$$

common to all sulfur cycles, is, in reality, the result of two separate reactions. As $\mathrm{H}_{2} \mathrm{SO}_{4}$ is vaporized and superheated, it spontaneously decomposes into water $\left(\mathrm{H}_{2} \mathrm{O}\right)$ and sulfur trioxide $\left(\mathrm{SO}_{3}\right)$,

$$
\mathrm{H}_{2} \mathrm{SO}_{4}(a q) \leftrightarrow \mathrm{H}_{2} \mathrm{O}(g)+\mathrm{SO}_{3}(g)
$$

Further heating the vapor to high temperatures $\left(>800^{\circ} \mathrm{C}, 1073 \mathrm{~K}\right)$ in the presence of a catalyst drives the endothermic decomposition of $\mathrm{SO}_{3}$ into $\mathrm{O}_{2}$ and sulfur dioxide $\left(\mathrm{SO}_{2}\right)$,

$$
\mathrm{SO}_{3}(g) \leftrightarrow \mathrm{SO}_{2}(g)+1 / 2 \mathrm{O}_{2}(g)
$$




\section{Inputs:}

- Water

- Heat $\left(>800^{\circ} \mathrm{C}\right)$

- Electricity

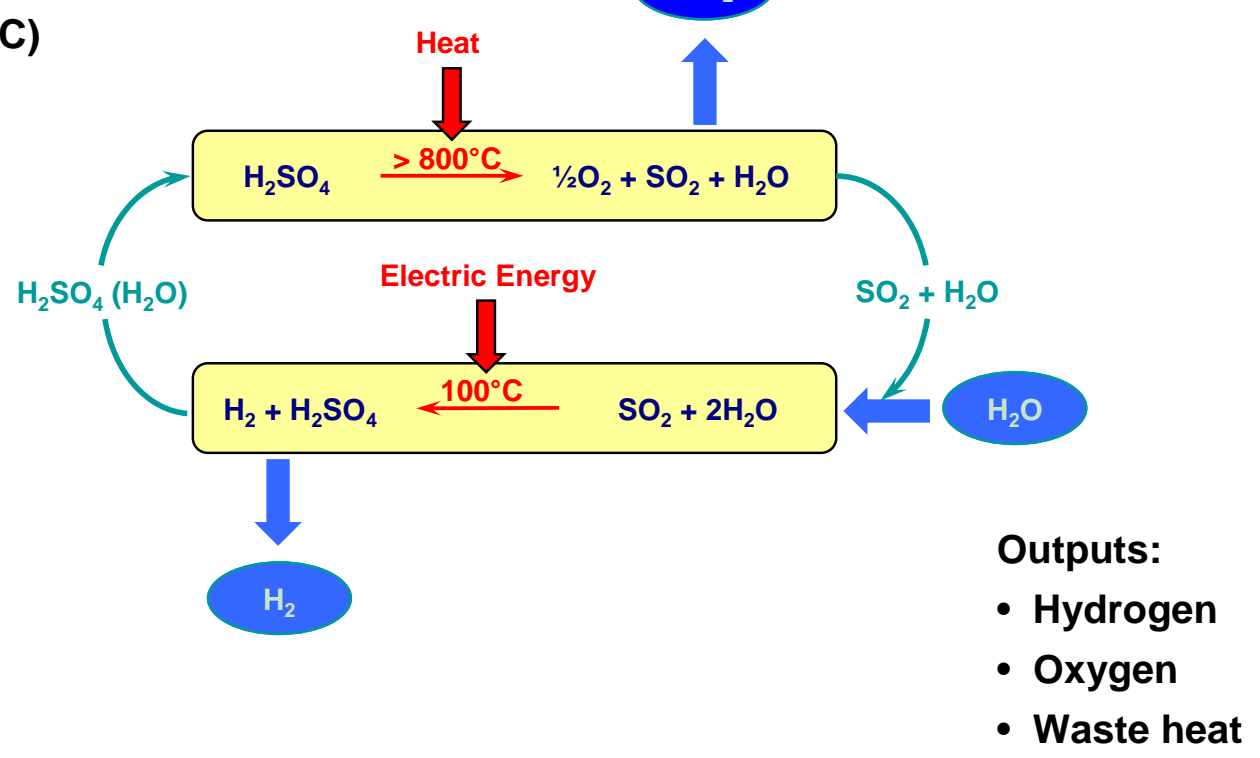

\section{Figure 3-1 The Hybrid Sulfur (HyS) Cycle}

After $\mathrm{O}_{2}$ is removed as a co-product, the $\mathrm{SO}_{2}$ and $\mathrm{H}_{2} \mathrm{O}$ are combined with make-up $\mathrm{H}_{2} \mathrm{O}$ (and recycled $\mathrm{H}_{2} \mathrm{SO}_{4}$ ) and fed to the anode of an electrolyzer, where the second reaction takes place. This is the $\mathrm{SO}_{2}$-depolarized electrolysis of water,

$$
2 \mathrm{H}_{2} \mathrm{O}+\mathrm{SO}_{2} \rightarrow \mathrm{H}_{2} \mathrm{SO}_{4}+\mathrm{H}_{2}
$$

illustrated in Figure 3-2.

$\mathrm{SO}_{2}$ is electrochemically oxidized at the anode to form $\mathrm{H}_{2} \mathrm{SO}_{4}$, protons, and electrons.

$$
\mathrm{SO}_{2}(a q)+2 \mathrm{H}_{2} \mathrm{O}(l) \rightarrow \mathrm{H}_{2} \mathrm{SO}_{4}(a q)+2 \mathrm{H}^{+}+2 e^{-}
$$

The protons are conducted across the electrolyte separator to the cathode, where they recombine with the electrons, which pass through an external circuit, to form $\mathrm{H}_{2}$.

$$
2 \mathrm{H}^{+}+2 e^{-} \rightarrow \mathrm{H}_{2}(g)
$$

The net result is $\mathrm{H}_{2} \mathrm{SO}_{4}$ production at the anode and $\mathrm{H}_{2}$ production at the cathode. $\mathrm{H}_{2} \mathrm{SO}_{4}$ is recycled to the high-temperature decomposition step to complete the cycle, while $\mathrm{H}_{2}$ is removed as the principal product. 


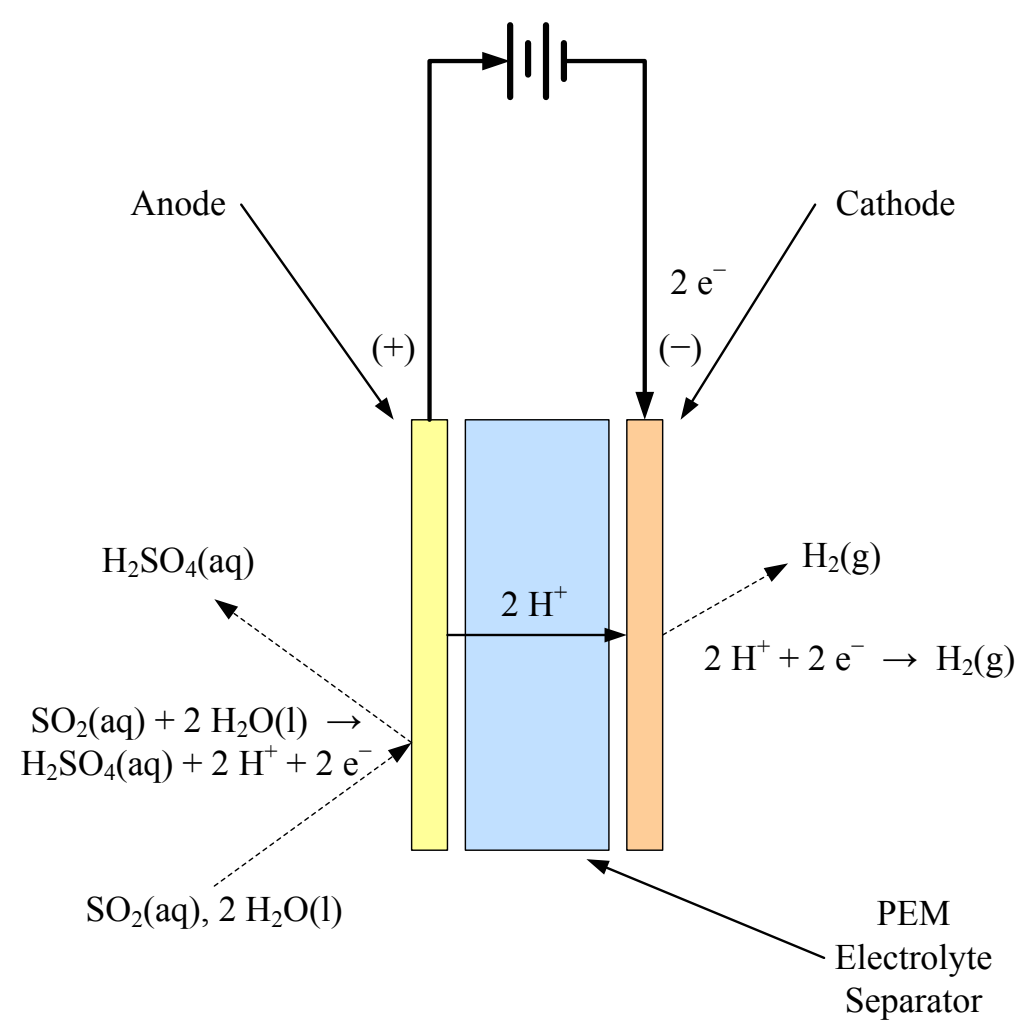

Figure 3-2 $\mathrm{SO}_{2}$-Depolarized Electrolysis

What makes the HyS cycle attractive is the standard cell potential for $\mathrm{SO}_{2}$-depolarized electrolysis, which is only $-0.158 \mathrm{~V}$ at $25^{\circ} \mathrm{C}(298 \mathrm{~K})$ in water [6,7]. The reversible potential increases in magnitude to $-0.243 \mathrm{~V}$ if $\mathrm{SO}_{2}$ is dissolved to saturation at 1 bar total pressure in a $50-\mathrm{wt} \% \mathrm{H}_{2} \mathrm{SO}_{4}-\mathrm{H}_{2} \mathrm{O}$ solution, the most likely anolyte ${ }^{1}$. This means that the SDE will consume much less electricity per mole of $\mathrm{H}_{2}$ product than water electrolysis, which has a reversible cell potential of $-1.229 \mathrm{~V}$ at $25^{\circ} \mathrm{C}(298 \mathrm{~K})[6,7]$, and which is an obvious $\mathrm{H}_{2}$ production alternative.

\subsubsection{The $\mathrm{SO}_{2}$-Depolarized Electrolyzer}

A major challenge for the HyS Process is the development of an efficient, cost-effective electrochemical reactor, or SDE. The SRNL is leading efforts supported by the DOE Nuclear Hydrogen Initiative to develop the SDE. In contrast to previous efforts to develop an SDE, SRNL has based its work on the use of proton exchange membrane (PEM) technology. The advantages of this design concept include high electrochemical efficiency, small footprint, and potential for competitive capital cost, all of which are crucial for successful implementation on a commercial scale. Since PEM technology is also the subject of intense development efforts for use in water electrolyzers and automotive fuel cells, there is the opportunity for leveraging that work for improving the SDE. The application is

\footnotetext{
${ }^{1}$ Correction for nonstandard condition calculated using the Nernst equation [7], with species activities obtained from the Mixed Solvent Electrolyte model in OLI Systems, Inc.'s OLI Engine 7.0.
} 
challenging, however, since the $\mathrm{SDE}$ must react $\mathrm{SO}_{2}$ with water to produce hydrogen in the presence of strong sulfuric acid under elevated temperature and pressure.

The baseline electrolyzer design approach involves operation with liquid anolyte feed comprised of sulfuric acid containing dissolved $\mathrm{SO}_{2}$. Hydrogen gas is evolved at the cathode. Due to the corrosive nature of the acid, all wetted components must be constructed of carbon or polymeric materials. A test facility, capable of testing SDEs at elevated temperature and pressure in the presence of $\mathrm{SO}_{2}$ and sulfuric acid was constructed. Candidate PEM electrolytes were obtained and characterized by testing for proton conductivity and $\mathrm{SO}_{2}$ transport. Testing was also conducted to determine the performance of various electrocatalysts. The most promising membranes and electrocatalysts were assembled into membrane-electrode assemblies (MEAs) for introduction into a test electrolyzer. A robust, versatile PEM-type SDE with a nominal $60-\mathrm{cm}^{2}$ active area was designed and constructed. Testing was performed for various cell components and configurations. Collaboration was established with an industrial electrolyzer manufacturer (Giner Electrochemical Systems, LLC) and a larger, multi-cell electrolyzer was designed, constructed and tested. Future development will include the design and construction of an integrated lab-scale (ILS) experiment that will demonstrate operation of a complete closedcycle HyS Process. A photograph of the SRNL HyS electrolyzer test facility is shown in Figure 3-3 and the multi-cell stack is shown in Figure 3-4.

In addition to development and testing of complete SDE units, SRNL has an active program in component development with the aim of improving overall cell performance and lifetime. Studies in electrolyzer component development are focused on three main areas: 1) identification, characterization, and joint development with others of advanced cell membranes; 2) evaluation of electrocatalysts; and 3) the fabrication and post-test characterization of MEAs for use in the single cell electrolyzer. One of the major challenges for the $\mathrm{SDE}$ is the prevention of $\mathrm{SO}_{2}$ diffusion through the cell membrane from the anode side to the cathode, where it can be reduced to elemental sulfur. Thus, identification of a membrane that exhibits much lower transport of $\mathrm{SO}_{2}$ is needed to reduce the quantity of $\mathrm{SO}_{2}$ that reaches the cathode catalyst. Three candidate membranes are currently being evaluated that have shown promise from preliminary studies, (1) modified Nafion $\AA$, (2) polybenzimidazole (PBI), and (3) sulfonated Diels Alder polyphenylene (SDAPP). 

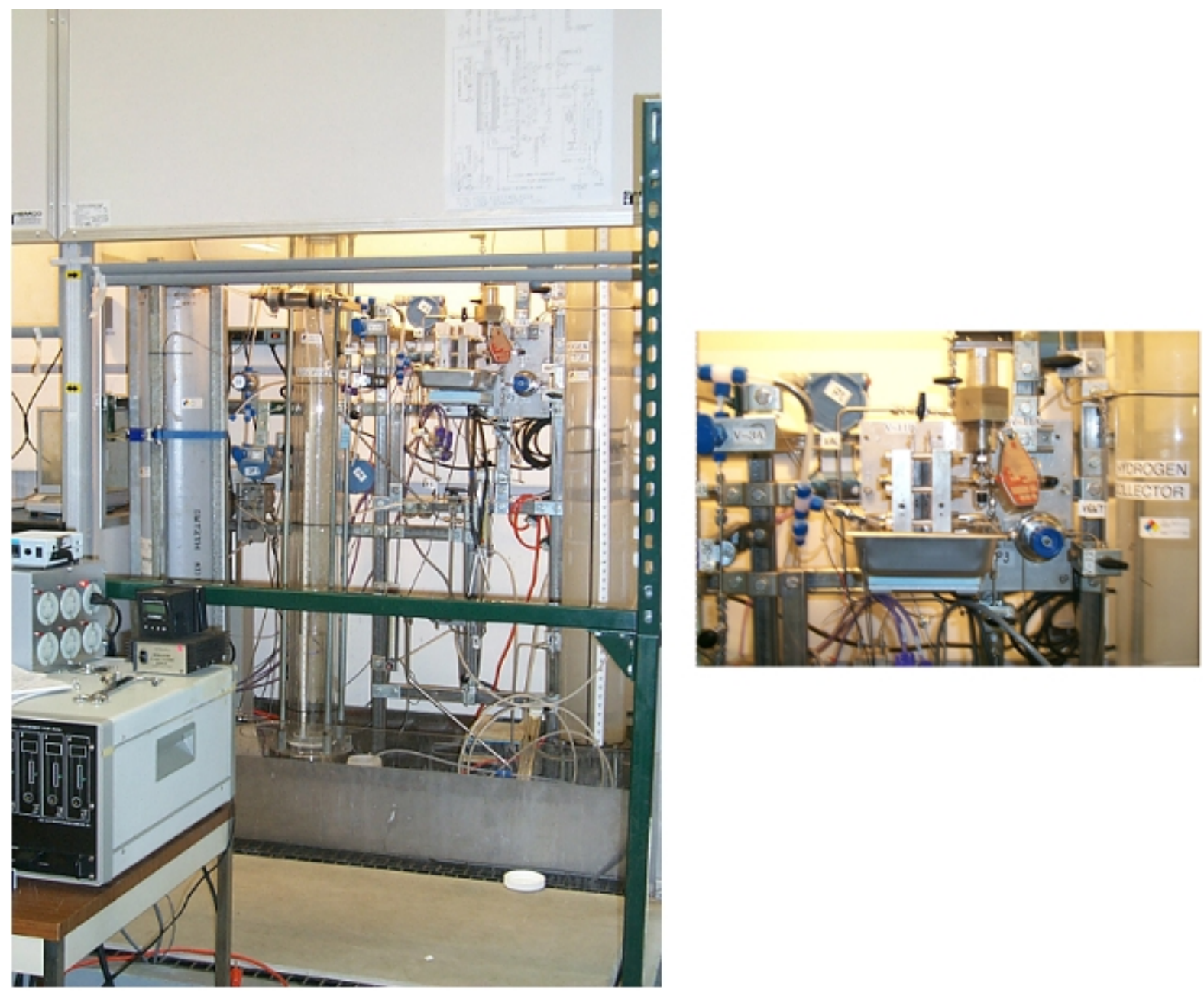

Figure 3-3 HyS Electrolyzer Test Facility showing close-up of 60-cm test unit
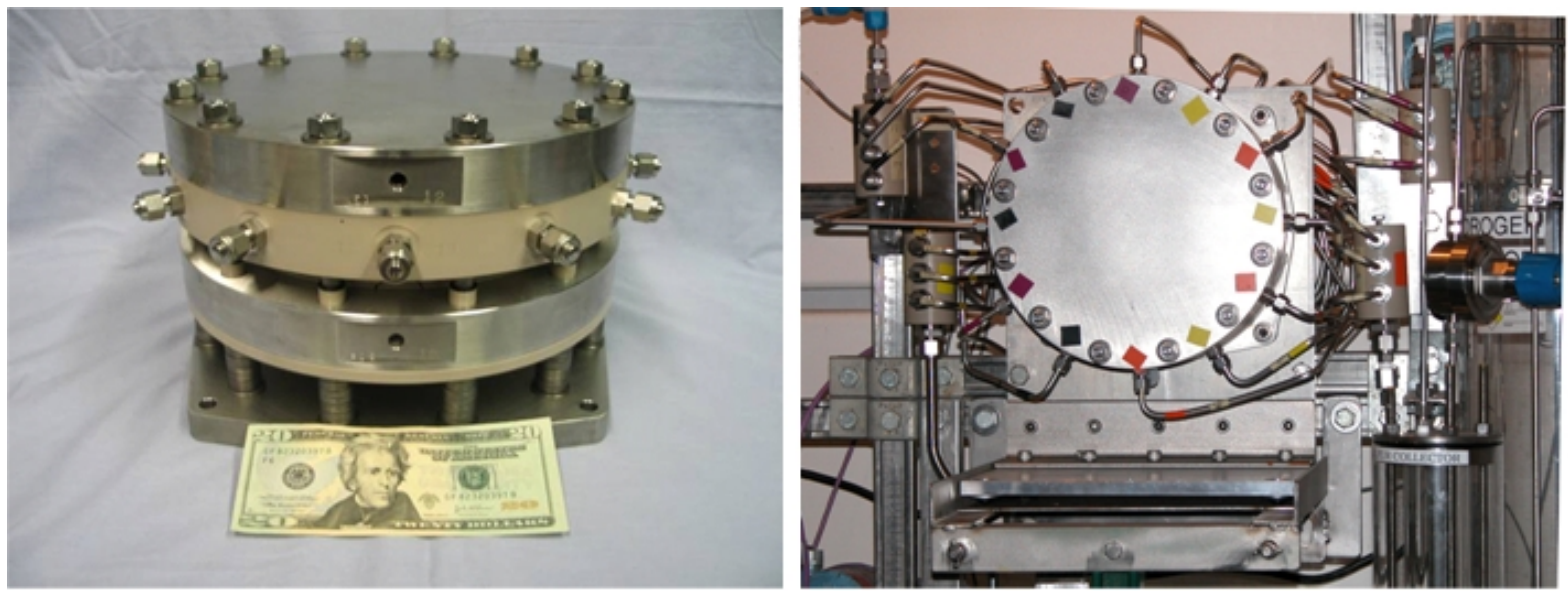

Figure 3-4 Multi-cell HyS Electrolyzer Stack 
Efforts in electrocatalyst development are aimed at lowering the operating cell potential. Results of empirical analysis indicate the major overpotential contribution ( $70 \%$ of all losses) arises from the slow reaction rate of oxidation of $\mathrm{SO}_{2}$ at the anode. Therefore, identification of a means to increase reaction kinetics at the anode will provide the largest source of improvement in cell performance. This might be accomplished through a combination of operation at a higher temperature (which may require a new membrane) and development of a better catalyst for $\mathrm{SO}_{2}$ oxidation.

The electrolyzer test facility and the single cell SDE have been used to test a total of 27 different MEA configurations to date (16 within the last year). A 100-hour continuous longevity test was successfully completed for the single cell electrolyzer using a Nafion 115 membrane. A voltage increase of approximately $5 \%$ was observed over the duration of the test, and post-test examination showed some delamination of the cathode layer caused by sulfur formation. The multi-cell SDE stack consisting of three cells with an active cell area of $160 \mathrm{~cm}^{2}$ each, for a total of $480 \mathrm{~cm}^{2}$, was tested for over 50 hours with maximum hydrogen output of $86 \mathrm{~L} / \mathrm{hr}$.

Future work will consist of continuing to characterize and incorporate advanced membranes and design concepts to improve cell performance. The test facility will be automated to permit unattended, longer duration testing. The next major step in the development of the SDE will be the design, construction and operation of an ILS experiment of the entire Hybrid Sulfur Process, including both the electrochemical step and the high-temperature acid decomposition step. Scale-up to both larger cell sizes (greater cell active area) and larger stacks (more cells in series) are required to reach commercial sizes.

\subsubsection{The Acid Decomposition Reactor}

One of the most difficult challenges in decomposing sulfuric acid at high temperatures $\left(>800^{\circ} \mathrm{C}, 1073 \mathrm{~K}\right)$ and pressures (up to $90 \mathrm{bar}$ ) is finding a material that can contain the process at the required conditions without significantly corroding or deteriorating, while providing adequate heat transfer characteristics. Silicon carbide ( $\mathrm{SiC}$ ) is among the handful of substances identified so far that meet these requirements. Since $\mathrm{SiC}$ is ceramic, it can not be shaped as easily as metal. This greatly complicates the design and fabrication of process vessels and fluid conduits. A particular concern is making and maintaining sealed joints between individual $\mathrm{SiC}$ and $\mathrm{SiC}$-metal components that operate at high temperature and pressure.

The two leading thermochemical cycles, HyS and Sulfur-Iodine (SI) share the hightemperature decomposition of sulfuric acid as a common step. Responsibility for developing this reaction process for the NHI program belongs to Sandia National Laboratories (SNL), which was initially assigned to do this as part of an international collaboration with General Atomics (GA) and France's Commissariat à l'Energie Atomique (CEA) to build an integrated SI cycle demonstration at GA [8]. The same process should be easily adaptable to the HyS cycle, with minor modifications. 
SNL has devised an innovative solution that makes use of readily available $\mathrm{SiC}$ shapes and does not have any high-temperature connections [9]. Their bayonet decomposition reactor features internal recuperation and allows all of the connections to be made at relatively low temperatures, where polytetrafluoroethylene (PTFE) and similar materials can be used for seals. The essential elements of SNL's bayonet decomposition reactor are shown in Figure 9-1.

In its simplest form, the reactor consists of one closed ended $\mathrm{SiC}$ tube co-axially aligned with an open ended $\mathrm{SiC}$ tube to form two concentric flow paths. A baffle tube may be included to enhance heat transfer. High-temperature heat is applied externally, except near the open end. Concentrated liquid $\mathrm{H}_{2} \mathrm{SO}_{4}$ is fed at the open end to the annulus, where it is vaporized before passing through an annular catalyst bed. The decomposition reaction takes place in the catalyst bed, using heat provided by the external heat source. $\mathrm{SO}_{2}, \mathrm{O}_{2}$, and $\mathrm{H}_{2} \mathrm{O}$ vapor product returns through the center and loses its heat to the feed through recuperation. Cooled and partially condensed product exits out the open end into a metal base or manifold at a temperature low enough $\left(\leq \sim 250^{\circ} \mathrm{C}\right.$, or $\left.523 \mathrm{~K}\right)$ to allow the use of PTFE seals. Imbedding the open ends of the $\mathrm{SiC}$ tubes in a metallic manifold facilitates the transition to metal pipe.

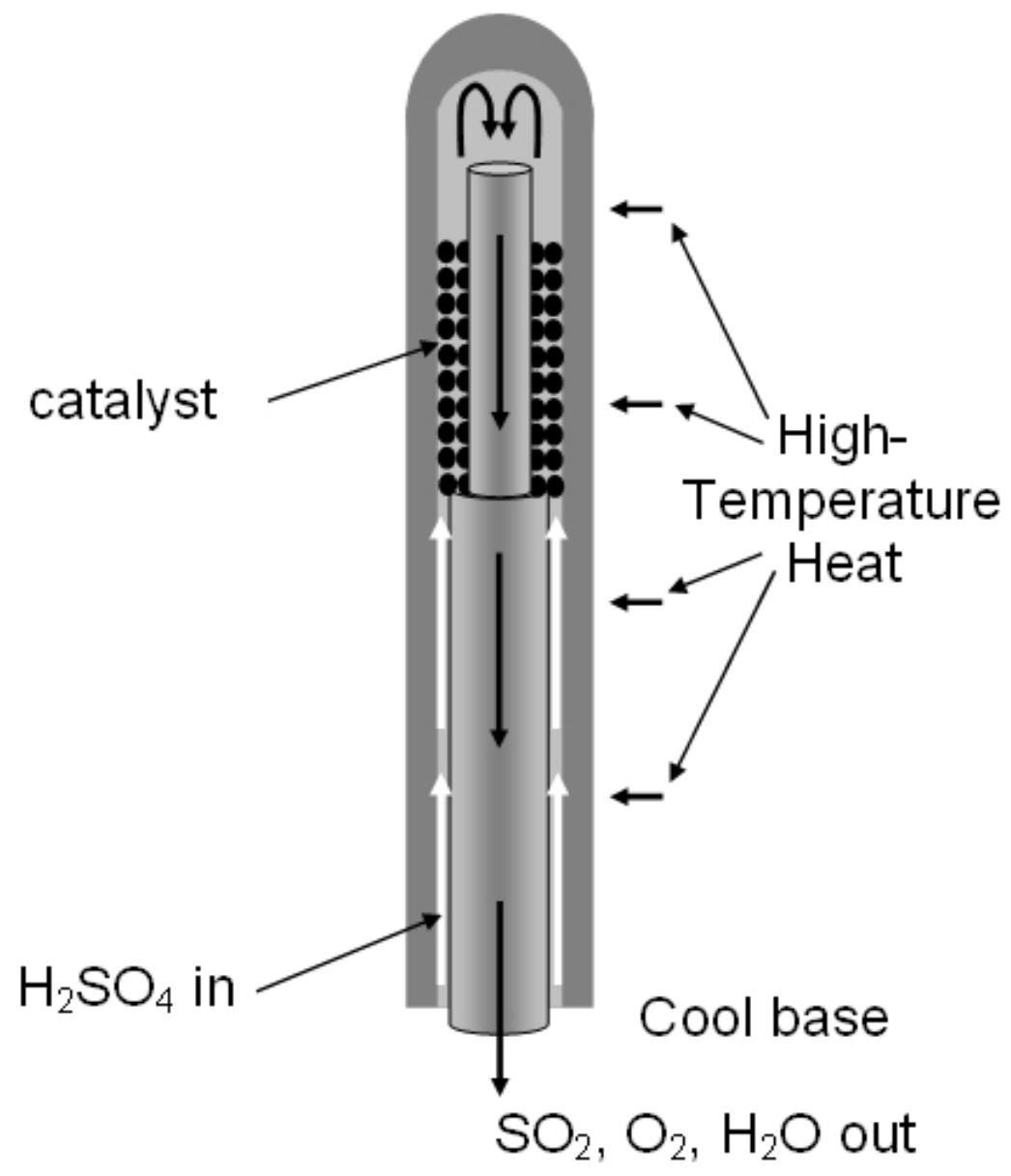

Figure 3-5 Schematic diagram of the SNL bayonet decomposition reactor 
The catalyst for this reactor is being developed by Idaho National Laboratory (INL) as part of the NHI.

Heat transfer limitations will impose a high surface-to-volume ratio limit, keeping diameters small, so it should be obvious that a single bayonet will not have sufficient capacity for a full-scale reactor. However, it is easy to envision an arrangement in which many bayonets are attached in parallel to a manifolded base plate to achieve the necessary production rate. This would be at least somewhat analogous to the common practice with commercial fixed bed catalytic reactors, in which an endothermic reaction is carried out in parallel in multiple narrow tubes held between two tubesheets, with the heat source on the shell side.

Advantages of the bayonet design include internal heat recuperation, the need for lowtemperature connections only, corrosion resistance, and low fabrication cost. In fact, $\mathrm{SiC}$ bayonets are an off-the-shelf item, since they are used commercially for thermowells. ${ }^{2}$

\subsubsection{Energy Considerations}

The benchmark against which the HyS cycle will ultimately be judged is the use of conventional nuclear power generation coupled with water electrolysis. Both are proven technologies that could be deployed almost immediately, although this would require a large scale-up from existing water electrolysis plants. In order for the more complex HyS cycle to be competitive with the simpler, direct electrolysis of water, it needs to provide a significant advantage in terms of higher process thermal efficiency.

If the HyS plant has a higher thermal efficiency, it will require a smaller nuclear heat source than the water electrolyzer plant. Since the nuclear heat source is expected to be the most capital intensive portion of the plant, the nuclear-HyS plant could be expected to have a lower total capital investment (nuclear plant plus hydrogen plant) and a resulting lower hydrogen production cost. This could be offset, however, if there is an overwhelming difference in the capital cost between the two hydrogen production processes, or if the efficiency difference is minor. Future studies will investigate this issue and the trade-offs between plant efficiency and capital cost. Qualitatively, however, it is clear that the HyS plant efficiency must be substantially better than the water electrolysis plant efficiency.

Commercial water electrolyzers operate at cell potentials of -1.7 to $-2.0 \mathrm{~V}$ when economically reasonable current densities are maintained. Ohmic losses and electrode overpotentials are responsible for the voltage increase over the $1.229 \mathrm{~V}$ of the reversible cell. Likewise, SDEs in which the $\mathrm{SO}_{2}$ is dissolved in $50 \mathrm{wt} \% \mathrm{H}_{2} \mathrm{SO}_{4}$ are expected to operate with cell potentials significantly greater than $-0.243 \mathrm{~V}$ at practical current densities.

In 1981, Lu et al. [10] predicted that cell potentials of -0.45 to $-0.75 \mathrm{~V}$ could be obtained at current densities of 100 to $400 \mathrm{~mA} / \mathrm{cm}^{2}$ for properly designed and optimized SDEs. Recent experience with PEM SDE development at SRNL suggests that cell potentials of $-0.6 \mathrm{~V}$ should be attainable at practical current densities with higher operating temperatures

\footnotetext{
${ }^{2}$ For example, Saint-Gobain Ceramics markets Hexoloy ${ }^{\circledR}$ sintered alpha silicon carbide thermowells that range from 6 to 54 in $(0.15$ to $1.37 \mathrm{~m})$ in length and from 0.375 to 1.5 in $(0.0953$ to $0.0381 \mathrm{~m})$ in diameter.
} 
$\left(\geq 100^{\circ} \mathrm{C}, 373 \mathrm{~K}\right)$ and pressures ( $\geq 10$ bar). The target of SRNL's SDE development program is, in fact, a potential of $-0.6 \mathrm{~V}$ at a current density of $500 \mathrm{~mA} / \mathrm{cm}^{2}$.

Therefore, it is anticipated that the HyS SDE will operate with a cell potential significantly lower than that of a conventional alkaline electrolyzer. In order for the more complex HyS cycle to be competitive with the simpler, direct electrolysis of water, the thermal energy required to effect the decomposition of $\mathrm{H}_{2} \mathrm{SO}_{4}$ will need to be substantially less than the thermal equivalent of the difference in cell potentials. In that case, the net thermal efficiency of the HyS cycle will be greater than that for conventional electrolysis, meaning that a given production rate of $\mathrm{H}_{2}$ will require a significantly smaller nuclear heat source using $\mathrm{HyS}$ instead of simple electrolysis. Since the nuclear heat source is expected to be the most expensive component of the process, HyS would then have the lower production cost.

Existing nuclear power plants generate electricity using either a boiling water reactor (BWR) or pressurized water reactor (PWR) combined with a steam-driven Rankine cycle power conversion unit (PCU). The maximum temperature of the steam is typically less than $315^{\circ} \mathrm{C}$ $(588 \mathrm{~K})$, and the overall thermal-to-electric conversion efficiency for the power plant is approximately $33 \% . \mathrm{H}_{2}$ can be produced via water electrolysis with an electric-to-higher heating value (HHV) conversion efficiency of 74 to $81 \%[11,12]^{3}$. Combining the two steps would allow $\mathrm{H}_{2}$ to be produced from nuclear energy at an overall HHV efficiency of 24 to $27 \%$. This represents a heat requirement of $4.5 \mathrm{MW}_{\text {th }}$ of fission heat to make a one-MW $\mathrm{MW}_{\text {th }}$ equivalent of $\mathrm{H}_{2}$ (in terms of fuel value) using conventional nuclear power plant (BWR or PWR) technology.

The overall efficiency could be increased by utilizing a PBMR power source, which has a higher thermal-to-electric conversion efficiency. An HTGR can produce hot helium at $950^{\circ} \mathrm{C}(1223 \mathrm{~K})$ and be combined with a helium-driven closed-loop Brayton cycle PCU. The resulting thermal-to-electric conversion efficiency could be $42 \%$. In that case, the overall $\mathrm{HHV}$ efficiency of $\mathrm{H}_{2}$ production for an HTGR-water electrolysis hydrogen plant could be as high as $34 \%$, or $3.0 \mathrm{MW}_{\text {th }}$ of fission heat per one- $\mathrm{MW}_{\text {th }}$ equivalent of $\mathrm{H}_{2}$.

The HyS plant will not only require electricity for the SDE, but thermal energy for acid decomposition as well. In order for the HyS plant to exceed the nuclear-electrolysis plant efficiency, the thermal energy required to effect the decomposition of $\mathrm{H}_{2} \mathrm{SO}_{4}$ will need to be substantially less than the thermal equivalent of the difference in cell potentials between the SDE and the water electrolyzer. The electric power requirement for the HyS electrolysis step is $116 \mathrm{~kJ} / \mathrm{mol} \mathrm{H}$ product, based on an assumed SDE cell potential of $-0.6 \mathrm{~V}$. If a conventional BWR/PWR nuclear reactor is used to produce this electricity, the thermal equivalent is $352 \mathrm{~kJ} / \mathrm{mol} \mathrm{H}_{2}$. On the other hand, if a PBMR power plant operating with an assumed thermal-to-electric conversion efficiency of $42 \%$ is used instead, the thermal

\footnotetext{
${ }^{3}$ Alkaline electrolysis can produce $\mathrm{H}_{2}$ at pressure using $4.8 \mathrm{kWh} / \mathrm{Nm}^{3}$ [11], while PEM electrolysis requires about $4.4 \mathrm{kWh} / \mathrm{Nm}^{3}$ [12]. These figures are equivalent to 387 and $355 \mathrm{~kJ} / \mathrm{mol} \mathrm{H}_{2}$, respectively. The $\mathrm{HHV}$, or higher heating value, of $\mathrm{H}_{2}$ is $286 \mathrm{~kJ} / \mathrm{mol}$. An HHV efficiency of $80.6 \%$ implies that $286 / 0.806=355 \mathrm{~kJ}$ of electric energy is needed to make $1 \mathrm{~mol} \mathrm{H}_{2}$. For comparison, the LHV, or lower heating value, of $\mathrm{H}_{2}$ is 242 $\mathrm{kJ} / \mathrm{mol}$, so an $\mathrm{H}_{2} \mathrm{HHV}$ efficiency of $80.6 \%$ is equivalent to an $\mathrm{H}_{2}$ LHV efficiency of $68.2 \%$.
} 
equivalent of the power for the SDE is only $276 \mathrm{~kJ} / \mathrm{mol} \mathrm{H}_{2}$. Table $3-1$ shows the calculation for "allowable" thermal energy use in the HyS plant compared to the water electrolysis plant.

BWR/PWR-powered water electrolysis at $26.6 \%$ overall HHV efficiency would consume $1,076 \mathrm{~kJ}$ of thermal energy per mol $\mathrm{H}_{2}$ product. That leaves an allowance of as much as $1,076 \mathrm{~kJ}-352 \mathrm{~kJ}=724 \mathrm{~kJ}$ heat per $\mathrm{mol} \mathrm{H}_{2}$ for the $\mathrm{H}_{2} \mathrm{SO}_{4}$ decomposition step for the HyS plant to achieve the same overall plant efficiency. If a more efficient PBMR nuclear plant is used to generate the electricity, the PBMR-powered water electrolysis would have a 33.8\% overall HHV efficiency and would only consume $845 \mathrm{~kJ}$ of thermal energy per mol $\mathrm{H}_{2}$ product. This would leave an allowance of $845 \mathrm{~kJ}-276 \mathrm{~kJ}=569 \mathrm{~kJ}$ heat per $\mathrm{mol}_{2}$ for the $\mathrm{H}_{2} \mathrm{SO}_{4}$ decomposition step. A reasonable goal for the HyS plant might be a high-temperature heat requirement for $\mathrm{H}_{2} \mathrm{SO}_{4}$ decomposition (and auxiliaries) of no more than about 450 $\mathrm{kJ} / \mathrm{mol} \mathrm{H}_{2}$. In that case, the HyS plant would be about $33 \%$ and $18 \%$ more efficient than a water electrolysis plant using conventional nuclear and PBMR power plants for electricity production, respectively.

Table 3-1 Energy requirement allowances for the HyS process

\begin{tabular}{|c|c|c|}
\hline & $\begin{array}{c}\text { BWR/PWR } \\
\text { Nuclear Power } \\
\text { Plant }\end{array}$ & $\begin{array}{l}\text { PBMR Nuclear } \\
\text { Power Plant }\end{array}$ \\
\hline Thermal-to-electric conversion efficiency, $\%$ & 33 & 42 \\
\hline Water electrolysis efficiency (HHV), \% & 80.6 & 80.6 \\
\hline Nuclear-electrolysis plant efficiency (HHV), \% & 26.6 & 33.8 \\
\hline Thermal energy requirement, $\mathrm{kJ} / \mathrm{mol} \mathrm{H}_{2}$ & 1,076 & 845 \\
\hline HyS SDE cell voltage, V & -0.6 & -0.6 \\
\hline Electricity demand, $\mathrm{kJ} / \mathrm{mol} \mathrm{H}{ }_{2}$ & 116 & 116 \\
\hline Thermal equivalent of electricity, $\mathrm{kJ}_{\mathrm{th}} / \mathrm{mol} \mathrm{H}_{2}$ & 352 & 276 \\
\hline \multicolumn{3}{|l|}{$\begin{array}{l}\text { Heat available for } \mathrm{HyS} \text { high-temperature } \mathrm{H}_{2} \mathrm{SO}_{4} \\
\text { decomposition, } \mathrm{kJ} / \mathrm{mol} \mathrm{H}\end{array}$} \\
\hline For same efficiency as water electrolysis & 724 & 569 \\
\hline$+10 \%$ efficiency over water electrolysis & 626 & 492 \\
\hline$+25 \%$ efficiency over water electrolysis & 508 & 400 \\
\hline$+33 \%$ efficiency over water electrolysis & 454 & 359 \\
\hline$+50 \%$ efficiency over water electrolysis & 364 & 287 \\
\hline
\end{tabular}

\subsubsection{Heat Requirement for the Bayonet Decomposition Reactor}

It is important to establish what the heat requirement is for the bayonet decomposition reactor. As shown above, the acid decomposition portion of the HyS cycle can consume no more than about $450 \mathrm{~kJ} / \mathrm{mol} \mathrm{H}_{2}$ of high-temperature heat in order to be competitive with water electrolysis. 
The heating requirement was determined by means of a pinch analysis. The objective of this analysis was to quantify the high-temperature heating target, which provides a lower limit for the heat input needed to drive the decomposition reaction. The Second Law of Thermodynamics guarantees that the actual heat consumption can only be greater than or equal to the target value.

Since this was a bounding calculation, there was no need to do a detailed heat transfer design. Instead, the assumption was made that the bayonet design was adequate for achieving good heat transfer. This means that the reaction can be accomplished with a practical bayonet length and that reasonable temperature differences can be attained. For this calculation, a $25^{\circ} \mathrm{C}(25 \mathrm{~K})$ minimum difference between the temperature of the process fluid in the annulus and the temperature of the helium heat transfer medium flowing countercurrently across the bayonet surface was imposed. A smaller, $10^{\circ} \mathrm{C}(10 \mathrm{~K})$ temperature approach between the annulus and center tube fluids was also used.

The pinch analysis assumed that the process fluid moves through the Decomposition Reactor in plug flow, and that the catalyst allows the decomposition reaction to proceed to thermodynamic equilibrium at the local pressure, temperature, and composition. An Aspen Plus flowsheet model was devised to track the progress of a fluid element as it passes through the reactor, from the inlet, up the annulus and the catalyst bed, down the center tube, and to the outlet. Sufficiently small temperature increments were used (on the order of $10^{\circ} \mathrm{C}$ or 10 $\mathrm{K}$ ) to allow the construction of detailed heating and cooling curves (enthalpy as a function of temperature) for a determination of the heating target. Details of this model are provided elsewhere [13].

Results (inlet and outlet temperatures and heat duty for each fluid flow segment) from the full Decomposition Reactor model were imported into Aspen HX-Net for the pinch analysis. The heating target calculated from the resulting heating and cooling curves represents the minimum high-temperature heat input needed to carry out the decomposition reaction. Figure 3-6 illustrates a pinch analysis for the case of $80 \mathrm{wt} \% \mathrm{H}_{2} \mathrm{SO}_{4}$ feed, with the bayonet operating at 86 bar pressure (negligible pressure drop between feed and product) and a peak internal (process) temperature of $870^{\circ} \mathrm{C}(1143 \mathrm{~K})$. The catalyst bed inlet temperature is assumed to be $675^{\circ} \mathrm{C}(948 \mathrm{~K})$. This combination of temperatures and pressure would be typical for a PBMR heat source, operating at a $950^{\circ} \mathrm{C}(1223 \mathrm{~K})$ primary helium coolant outlet temperature and 87-bar outlet pressure, with a $50^{\circ} \mathrm{C}(50 \mathrm{~K})$ temperature drop across the intermediate heat exchanger. High pressures are needed to minimize the pressure differential between the hot secondary helium coolant flowing outside the bayonet and the interior process stream.

The lower curve in Figure 3-6 represents the temperature as a function of heat input (moving from left to right) for the fluid flowing through the annulus, while the upper curve tracks the temperature of the fluid flowing through the central tube of the bayonet as a function of heat removal (moving from right to left). The pinch point represents the closest approach between the temperatures of the two fluids $\left(10^{\circ} \mathrm{C}\right.$ or $\left.10 \mathrm{~K}\right)$ flowing counter currently under optimal heat transfer conditions. The difference between the enthalpies of the two curves at 
the highest temperature $\left(870^{\circ} \mathrm{C}\right.$ or $\left.1143 \mathrm{~K}\right)$, is $328.6 \mathrm{~kJ} / \mathrm{mol} \mathrm{SO}_{2}$. This is the heating target, which is the lowest possible high-temperature heat requirement for a Decomposition Reactor operating at the stated conditions. If all of the $\mathrm{SO}_{2}$ is delivered to the $\mathrm{SDE}$ and consumed to produce $\mathrm{H}_{2}$, this is equivalent to $328.6 \mathrm{~kJ} / \mathrm{mol} \mathrm{H}_{2}$. Since this number is significantly less than $450 \mathrm{~kJ} / \mathrm{mol} \mathrm{H}_{2}$, HyS flowsheets using an SDE operating at a cell potential of $-0.6 \mathrm{~V}$ coupled to a bayonet decomposition reactor heated by a PBMR heat source have the potential for a higher thermal efficiency than water electrolysis.

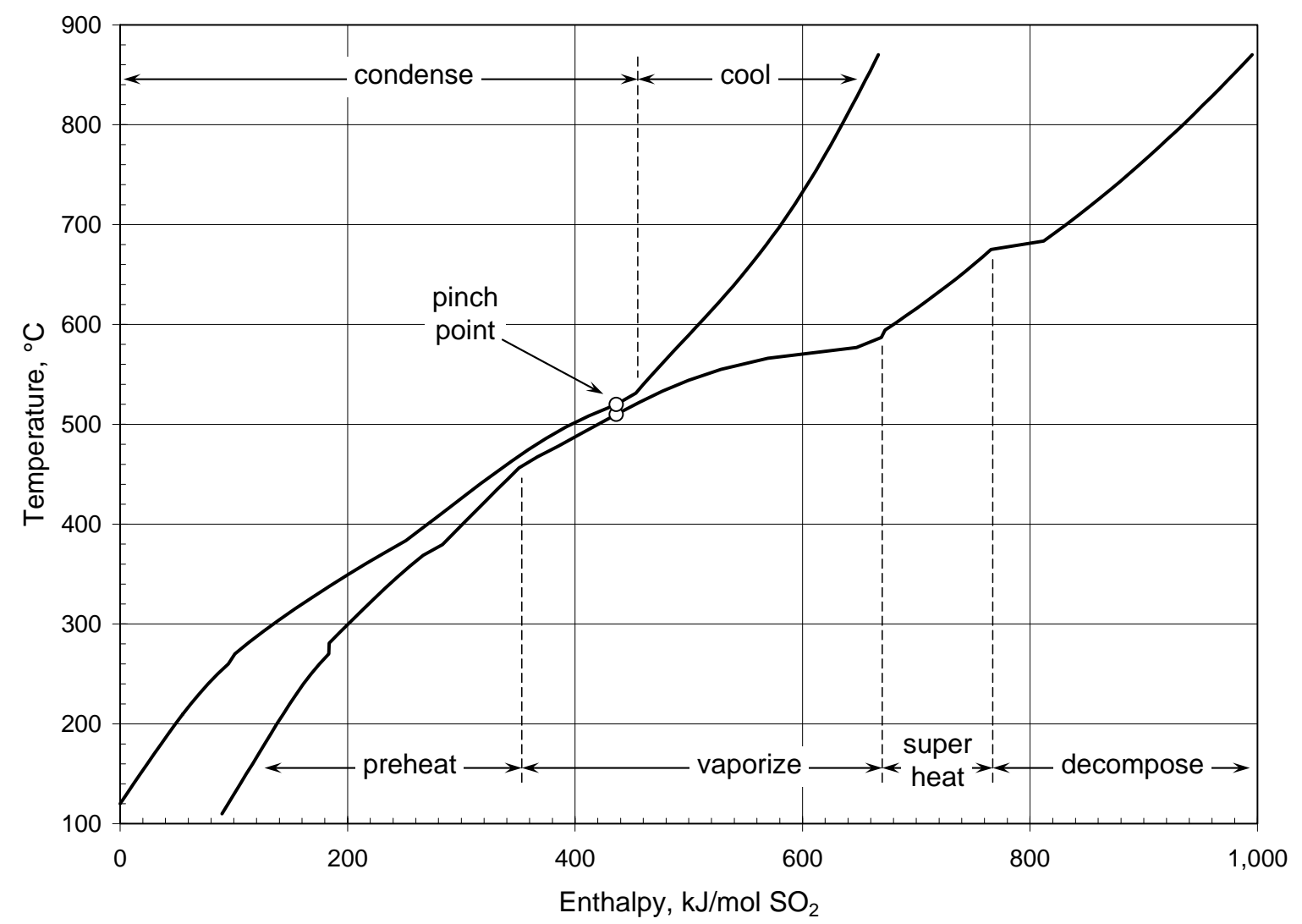

Figure 3-6 Decomposition Reactor heating and cooling curves $-80 \% \mathrm{H}_{2} \mathrm{SO}_{4}$ feed, 86bar pressure, $870^{\circ} \mathrm{C}(1143 \mathrm{~K})$ peak process temperature, $675^{\circ} \mathrm{C}(948 \mathrm{~K})$ catalyst bed inlet temperature

Pinch analyses were performed for a variety of Decomposition Reactor operating conditions. The results are summarized in Figure 3-7 and Figure 3-8. Figure 3-7 plots the hightemperature heat target for $\mathrm{H}_{2} \mathrm{SO}_{4}$ decomposition over a wide range of feed concentrations (30 to $85 \%$ ) for three different pressures (57, 70, and 83 bar), while Figure 3-8 plots the heat target over a more narrow range of feed concentrations (70 to 85\%) for four different pressures $\left(56,66,76\right.$, and 86 bar). In all cases, the peak process temperature was $870^{\circ} \mathrm{C}$ $(1143 \mathrm{~K})$, and the catalyst bed inlet temperature was $675^{\circ} \mathrm{C}(948 \mathrm{~K})$. The lowest heating targets (on the order of $330 \mathrm{~kJ} / \mathrm{mol} \mathrm{SO}_{2}$ ) were obtained for feed concentrations of $80 \%$ at all pressures. Heating targets were below $450 \mathrm{~kJ} / \mathrm{mol} \mathrm{SO}_{2}$ provided the feed concentration was $\geq 60 \mathrm{wt} \%$. 


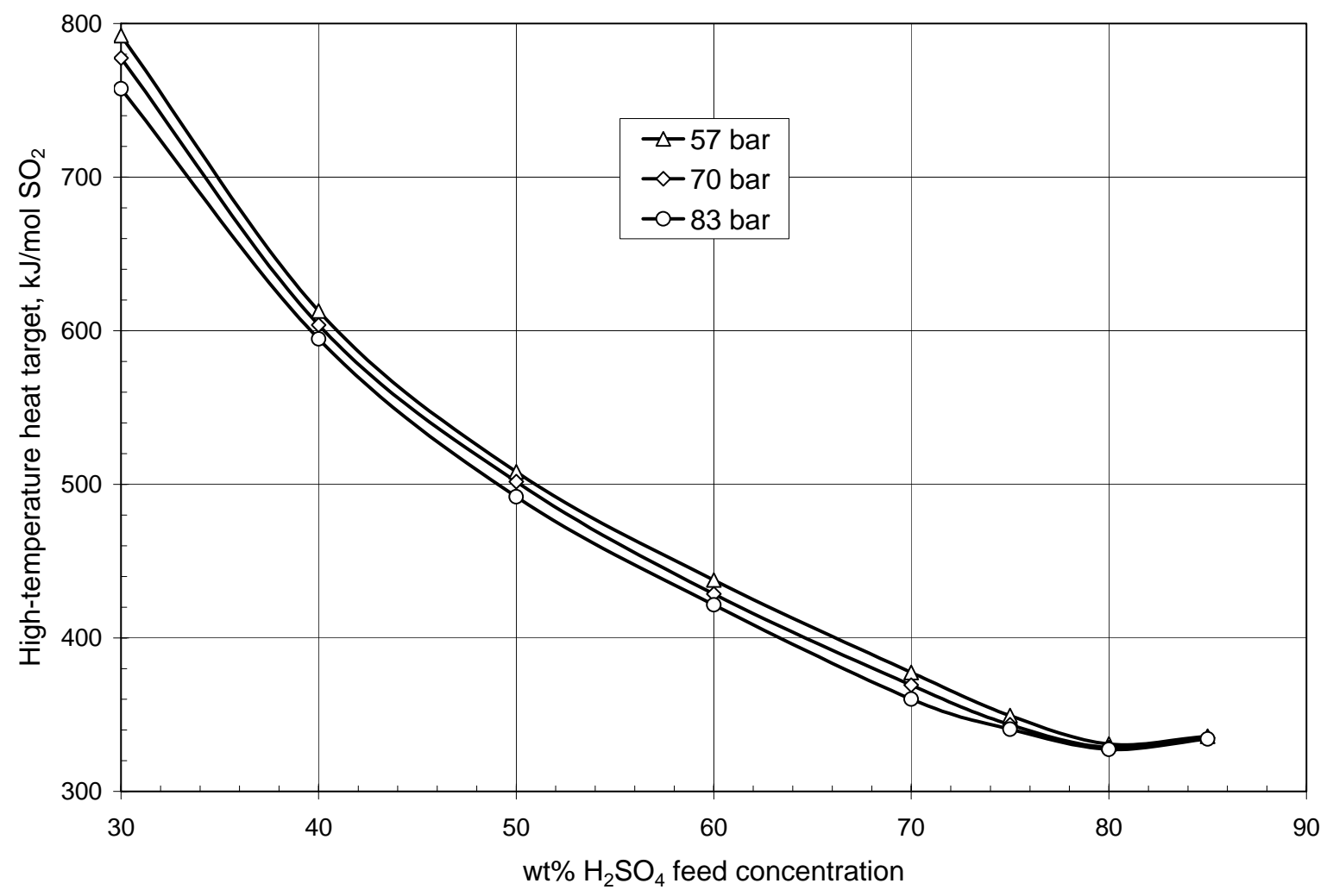

Figure 3-7 High-temperature heat requirement for $\mathrm{H}_{2} \mathrm{SO}_{4}$ decomposition as a function of feed concentration ( 30 to $85 \%)$ at three different pressures, $870^{\circ} \mathrm{C}(1143 \mathrm{~K})$ peak process temperature, $675^{\circ} \mathrm{C}(948 \mathrm{~K})$ catalyst bed inlet temperature

Results of PEM SDE development experiments at SRNL suggest that $50 \mathrm{wt} \%$ is the practical upper limit for anolyte acid concentration if a Nafion ${ }^{\circledR}$ or similar sulfonated perfluoroploymer PEM is used. That means the SDE product will need to be concentrated before being fed to the Decomposition Reactor, or else the high-temperature heat requirement will be impractical $\left(\geq 500 \mathrm{~kJ} / \mathrm{mol} \mathrm{SO}_{2}\right)$. Consequently, a HyS process that uses PEM electrolysis in conjunction with a bayonet decomposition reactor will need an acid concentration section, preferably one that can make use of heat recovered from the other flowsheet sections to effect the necessary separation. It will also need a decomposition product handling system to separate and remove $\mathrm{O}_{2}$ co-product while feeding $\mathrm{SO}_{2}$ and $\mathrm{H}_{2} \mathrm{O}$ to the SDE and recycling unconverted $\mathrm{H}_{2} \mathrm{SO}_{4}$ back to the bayonet. Such a flowsheet for coupling with a PBMR is described in Section 5.0 below. 


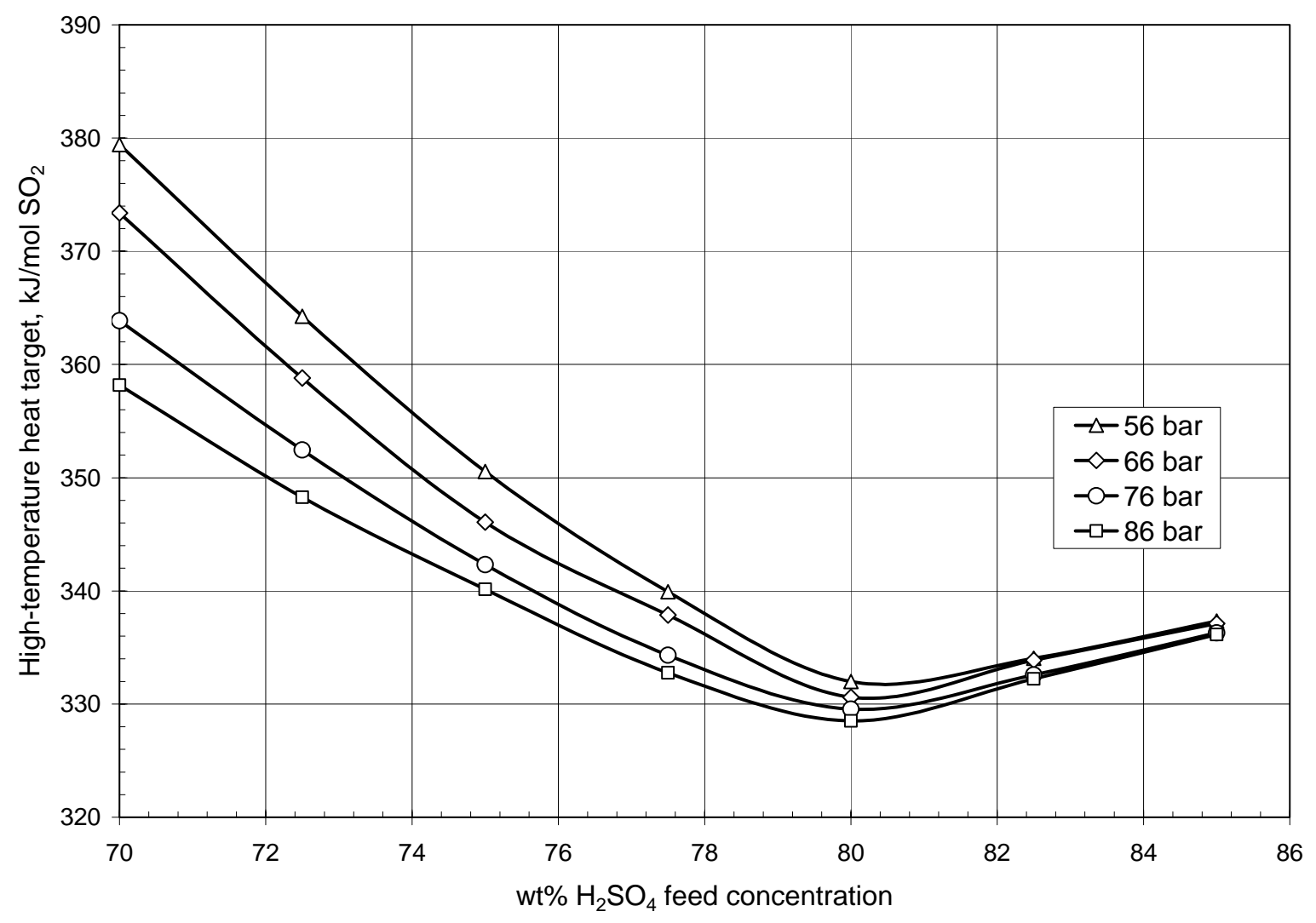

Figure 3-8 High-temperature heat requirement for $\mathrm{H}_{2} \mathrm{SO}_{4}$ decomposition as a function of feed concentration ( 70 to $85 \%)$ at four different pressures, $870^{\circ} \mathrm{C}(1143 \mathrm{~K})$ peak process temperature, $675^{\circ} \mathrm{C}(948 \mathrm{~K})$ catalyst bed inlet temperature 


\subsection{REACTOR - HYDROGEN PLANT INTERFACE}

The starting point for this HyS Process evaluation is the 500- $\mathrm{MW}_{\text {th }}$ commercial flowsheet which the Westinghouse-led team prepared for the NGNP Preconceptual Design (NGNP-07RPT-001 Rev. 0). In that process, $200 \mathrm{MW}_{\text {th }}$ is available as high temperature heat to decompose sulfuric acid $\left(950^{\circ} \mathrm{C}\right.$ down to $\left.659^{\circ} \mathrm{C}\right)$, with the remainder of the heat produced by the PBMR employed to make steam and generate electricity with a conventional Rankine power conversion cycle. For the HyS process in the NGNP Demonstration Project, in contrast to the commercial plant design, only one quarter of the available heat $\left(50 \mathrm{MW}_{\text {th }}\right)$ is used to decompose sulfuric acid. The commercial design, on the other hand, assumes that making hydrogen is the primary objective and, therefore, seeks to maximize the hydrogen production rate. One of the purposes of this study is to evaluate the impact of changing the reactor operating conditions and $\mathrm{PCHX}$ pinch temperature in an attempt to maximize the energy that is available for sulfuric acid decomposition.

\subsection{NUCLEAR HYDROGEN PRODUCTION}

As in the case of the NGNP, the Reference Design in the analysis documented by this report features indirect heating of the high-temperature Sulfuric Acid Decomposition Reactor (see Figure 4-1). A secondary helium (He) coolant loop between the primary He heat transfer loop and the HyS Process provides separation between the nuclear heat supply system and the hydrogen production system. Its pressure is nominally set 5 bar higher (at the intermediate heat exchangers) than either the process fluid or the primary PBMR coolant. This is intended to drive any leak between the fluids on either side of the interchangers away from the secondary loop, minimizing the risk of cross-contamination between the nuclear reactor and the process plant.

The basic configuration was assumed to be identical to the NGNP design, which is illustrated in Figure 4-2 below [14], with one major difference: instead of only a slipstream of hot secondary coolant being used to heat the sulfuric acid decomposition reaction, all of the hot He now passes through Decomposition Reactor (designated PCHX, for process coupling heat exchanger).

The PBMR heat source is the large gray vessel on the left-hand side. Hot primary He coolant exits the bottom of the reactor and enters the primary inlet of the two-stage Intermediate Heat Exchanger (IHX), represented by the two smaller gray vessels to the left of the center of the drawing. The primary outlet of the two-stage IHX feeds directly into the primary circulator (knob-like protrusion from the top of the right-hand side smaller gray vessel), which is mounted at the top of IHX B (the lower temperature heat exchanger). Cold primary He coolant is returned to the top of the PBMR via the red duct. 


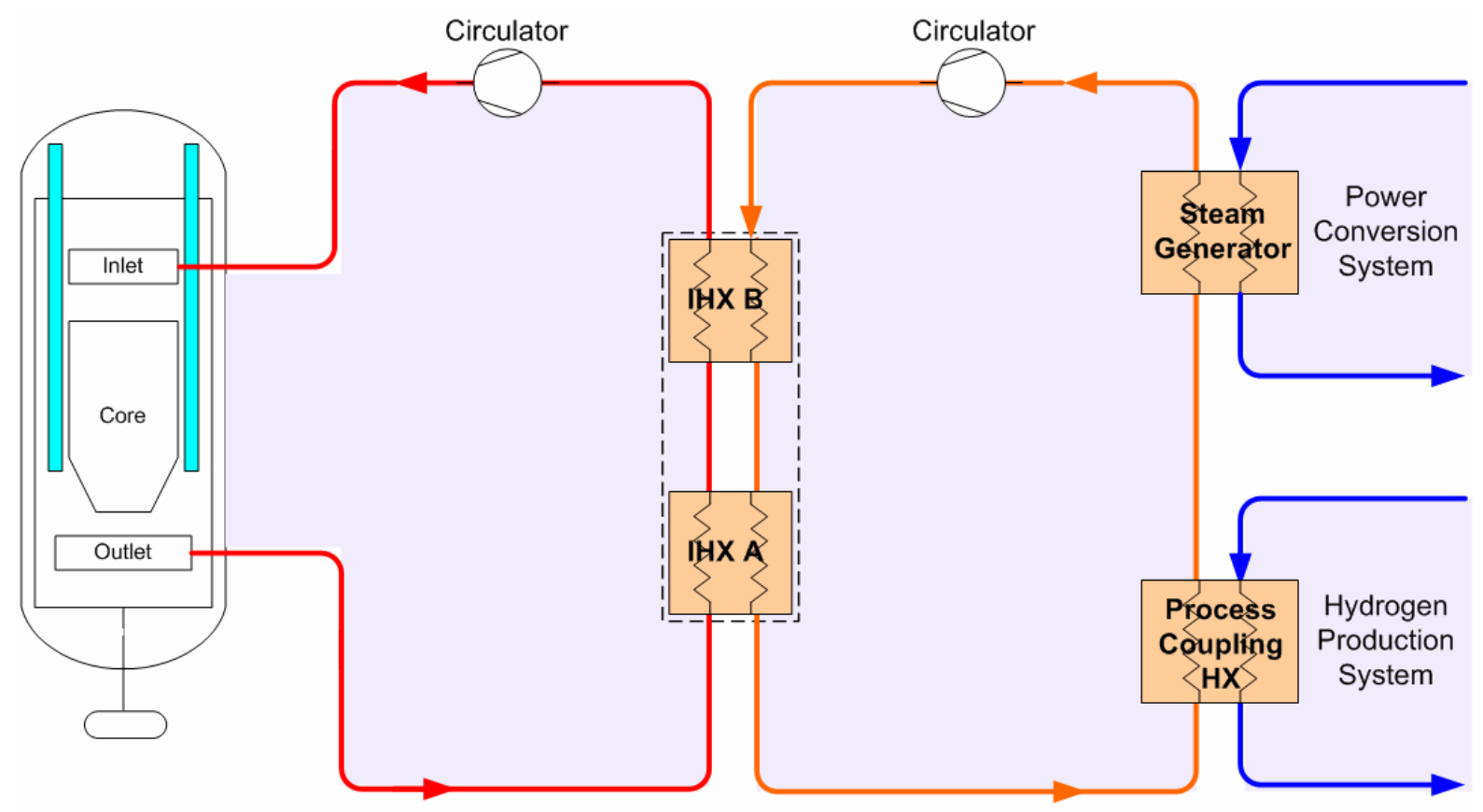

Figure 4-1 Schematic View of Nuclear Heat Supply System

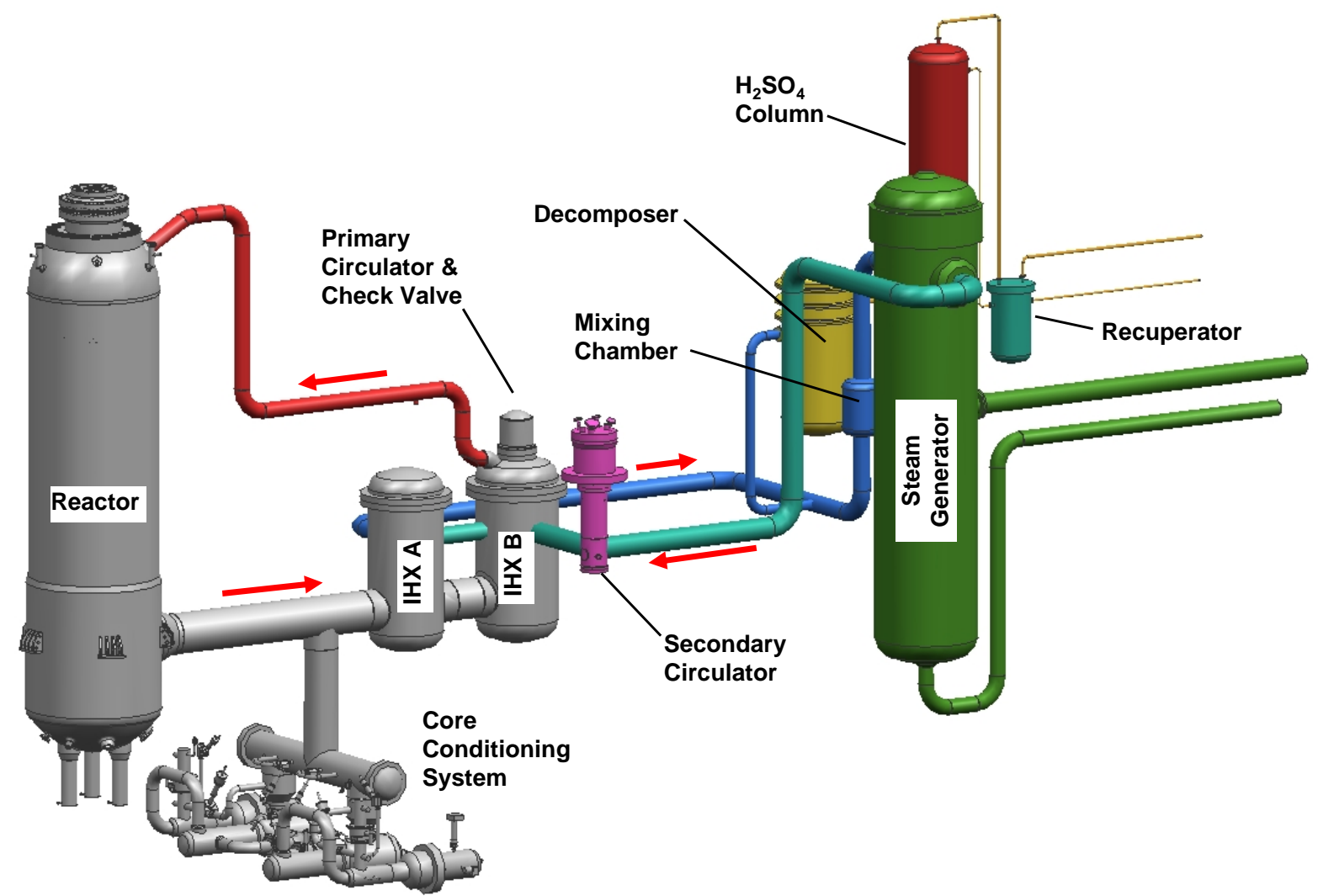

Figure 4-2 Three-Dimensional View of PBMR NGNP NHSS Design 
Hot secondary coolant exits the IHX A stage and is routed to the PCHX, which is the small yellow vessel labeled "Decomposer", using the blue duct exiting IHX A. Figure 4-2 shows what appears to be only a slipstream of the secondary He coolant actually being fed to the PCHX, with the majority bypassing the PCHX and going directly to the Steam Generator (SG). That is indeed the case for the NGNP Demonstration design, but in the NGNP Preconceptual Design commercial plant and this Reference Design all of the secondary coolant passes through the PCHX.

From the PCHX, the secondary He coolant is passed on to the SG through another length of blue duct. Cold secondary coolant is returned to IHX B via the turquoise-colored duct, passing through the magenta-colored secondary circulator on its way there to acquire the necessary motive force.

The Aspen Plus flowsheet used for the PBMR Nuclear Heat Supply System (NHSS) Reference Design performance simulations is shown in Figure 4-3. It should be clear that all of the hot secondary He coolant exiting the IHX (Primary Interchanger) is fed to the PCHX. This flowsheet was jointly developed by SRNL and PBMR engineers to be an accurate representation of the primary and secondary He heat transfer loops for the PBMR HyS Process Reference Design.

\subsection{DESIGN ENVELOPE CONSTRAINTS AND DESIGN OPTIONS}

The Aspen Plus flowsheet uses the BWR-LS property method, which reduces to the Benedict-Webb-Rubin virial equation-of-state for pure fluids, to represent the thermodynamic properties of pure He. It incorporates some PBMR design constraints that were identified by PBMR engineers.

The PBMR heat source is modeled as a Heater block (labeled PBMR) in which the pressure drop $(\triangle P, \mathrm{~Pa})$ varies with He mass flow rate and density via the relation,

$$
\Delta P=k W^{2}\left(1 / \rho_{\text {in }}+1 / \rho_{\text {out }}\right) / 2,
$$

where $\quad k=40 \mathrm{~m}^{-4}$ (fitted to data provided by PBMR),

$$
\begin{aligned}
& \rho_{\text {in }}=\text { inlet density, } \mathrm{kg} / \mathrm{m}^{3}, \\
& \rho_{\text {out }}=\text { outlet density, } \mathrm{kg} / \mathrm{m}^{3} \text {, and }
\end{aligned}
$$$$
W=\text { mass flow rate, } \mathrm{kg} / \mathrm{s} \text {. }
$$

Outlet temperature is assumed to be equal to $950^{\circ} \mathrm{C}$. 


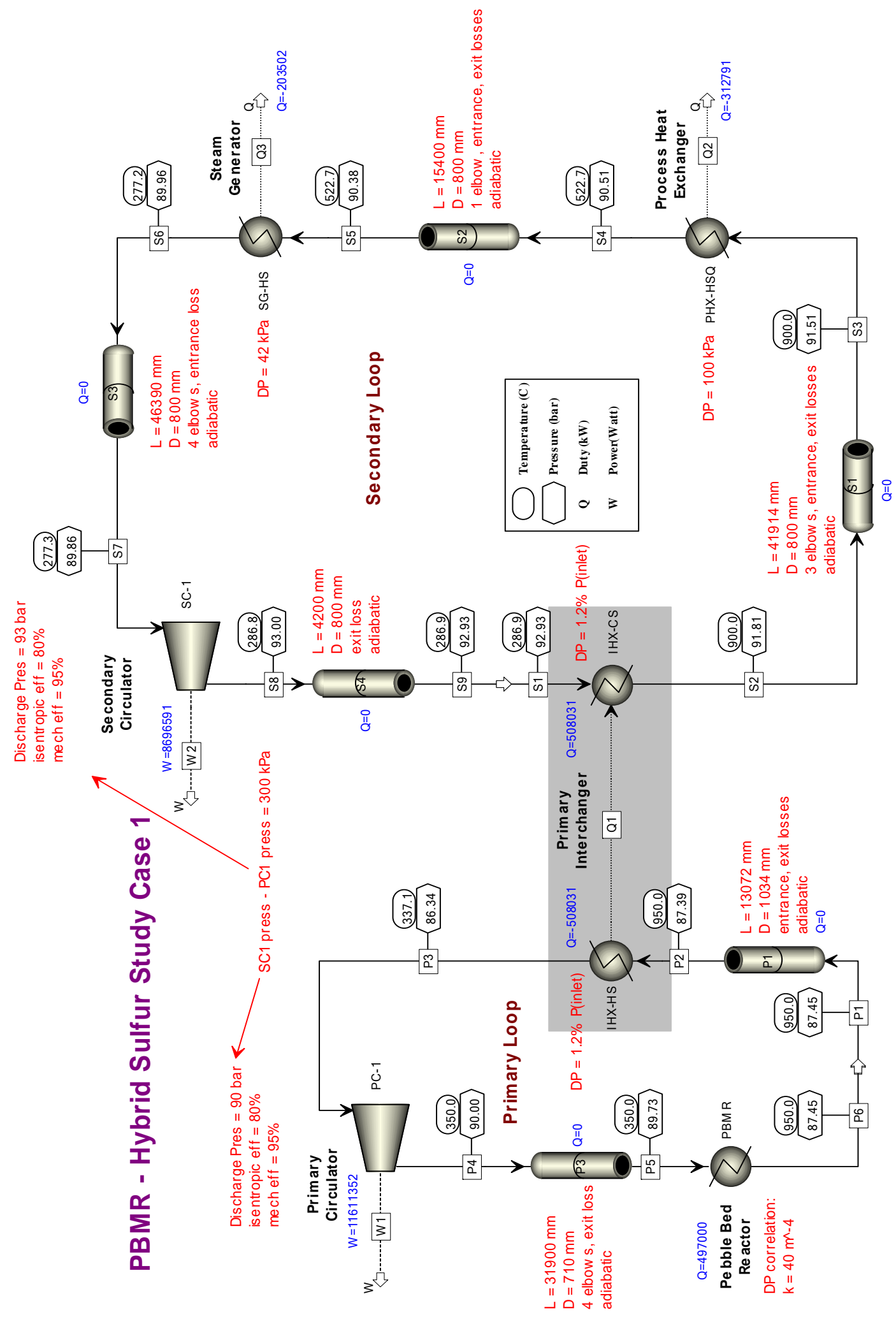

Figure 4-3 Aspen Plus Flowsheet for PBMR NHSS Reference Design 
Three constraints are considered for the operation of the PBMR using Design Specs. First, the heat duty is assumed to be limited to a maximum $497 \mathrm{MW}_{\text {th }}$ (with an implicit 3-MW $\mathrm{MW}_{\text {th }}$ heat loss to surroundings). The PBMR inlet temperature is assumed to be fixed at $350^{\circ} \mathrm{C}$. Next, Design Spec RX-ROT is used to adjust the mass flow rate of He in stream P1 to achieve a 497-MW th heat duty. Design Spec RX-RIT is used to adjust the primary He coolant outlet temperature from the IHX to achieve a $350^{\circ} \mathrm{C}$ PBMR inlet temperature. Finally, the volumetric flow rate of the primary He coolant at PBMR outlet conditions is limited to a maximum $54 \mathrm{~m}^{3} / \mathrm{s}$. Normally, this third constraint is automatically met when the first two are satisfied, but if the pressure of the primary coolant is reduced from the NGNP value of 87 bar at the IHX (90 bar at the circulator discharge), or if the PBMR inlet temperature is increased above $350^{\circ} \mathrm{C}$, or if the PBMR outlet temperature is reduced from $950^{\circ} \mathrm{C}$, it can come into play. Design Spec RX-CIRC is then used in place of RX-ROT to adjust the mass flow rate of He in stream $\mathrm{P} 1$ to achieve a $54 \mathrm{~m}^{3} / \mathrm{s}$ primary He coolant volumetric flow rate at PBMR outlet conditions. This results in a PBMR heat output of less than $497 \mathrm{MW}_{\text {th }}$, i.e. de-rated operation.

All of the ducts are specified as being adiabatic, i.e. heat losses are ignored, since they were not calculated for the NGNP Preconceptual Design, and detailed piping designs had yet to be done for the PBMR NHSS Reference Design. For the purpose of pressure drop estimates, a surface roughness of $40 \mu$ is also assumed throughout.

The flowsheet simulation begins with stream P1, which estimates the primary He coolant flow - temperature (specified), pressure (estimated), and flow rate (adjusted by Design Spec as noted above) - at the PBMR outlet.

Stream P1 enters block P1, which represents the hot gas duct between the PBMR outlet and the IHX inlet. Block P1 is modeled as an adiabatic cylindrical pipe (Pipe block) with an inside diameter of $1,034 \mathrm{~mm}$, and a length of $13,072 \mathrm{~mm}$. Entrance (flush, with an entrance $\mathrm{R} / \mathrm{D} \geq 0.15$ ) and exit loss allowances are included. The primary He coolant then enters the IHX as stream P2.

The IHX is treated as a single heat exchange operation. No duty-split between separate stages is simulated. Since detailed design data were unavailable and the overall pressure drop is assumed to be a fixed fraction of the inlet pressure, this is adequate for the purpose of these calculations. However, the primary, or hot side and the secondary, or cold side are modeled as separate Heater blocks (IHX-HS and IHX-CS, respectively) for convenience, with a heat stream (Q1), representing heat flow from the primary to the secondary He coolant loop, tying them together. Both blocks, IHX-HS and IHX-CS, are assumed to have pressure drops equal to $1.2 \%$ of their inlet pressures (imposed with calculator blocks DPIHX-HS and DPIHX-CS, respectively). The outlet temperature of IHX-HS is adjusted by a Design-Spec as noted above.

Cold primary He coolant (stream P3) next enters the primary circulator (Compr block PC-1), which is assumed to be mounted on the IHX outlet in the Reference Design. The circulator is 
assumed to operate with an isentropic efficiency of $80 \%$ and a mechanical efficiency of $95 \%$. The discharge pressure is fixed at 90 bar for the base case.

The circulator discharges cold primary He coolant (stream P4) to the duct that connects it to the PBMR inlet (block P3), which is modeled as an adiabatic cylindrical pipe (Pipe block) with an inside diameter of $710 \mathrm{~mm}$, and a length of 31,900 $\mathrm{mm}$. Exit loss and four large 90degree elbow allowances are also included.

The primary He coolant then enters the PBMR block, which has already been described in detail, as stream P5. Finally, a calculator block (PR-TEAR) sets the temperature and pressure of stream P1 equal to the temperature and pressure of the PBMR outlet (stream P6), treating them as tear variables that can be converged iteratively. This completes the simulation of the primary coolant loop.

The flowsheet simulation continues with the secondary loop in similar fashion. An estimate is made for stream S1 - temperature (estimated), pressure (estimated), and flow rate (set equal to the primary coolant flow rate by Calculator block SEC-CIRC) - which simulates the secondary He coolant at the IHX inlet.

Stream S1 enters the IHX cold side (Heater block IHX-CS), where it is heated by exchange with the primary coolant via heat stream Q1 and has its pressure reduced by $1.2 \%$ of the inlet value (via calculator block DPIHX-CS). Hot secondary He coolant (stream S2) is then passed to Pipe block S1, which simulates the duct that connects the IHX to the PCHX.

Block S1 treats the duct as an adiabatic cylindrical pipe with an inside diameter of $800 \mathrm{~mm}$, and a length of 41,914 mm. Pipe entrance (flush, with an entrance $R / D \geq 0.15$ ) and exit losses as well as three large 90-degree elbow allowances are also included. The hot secondary He coolant (stream S3) next enters the hot side of the PCHX, block PHX-HSQ.

It is sufficient to treat the hot side of the process heat exchanger (i.e. the Sulfuric Acid Decomposition Reactor) as a simple Heater block for this calculation. Detailed design data were unavailable, so a 100-kPa (1-bar) pressure drop is imposed, as agreed upon in consultation with Westinghouse, Shaw, and PBMR. Outlet temperature is the other specification. The temperature value is determined in a separate pinch analysis of the Decomposition Reactor, which is described in TBD below, and which depends on process conditions. The resulting PHX-HSQ heat duty, calculated by energy balance and transferred to heat stream Q2, essentially determines the HyS process hydrogen production rate, since it is the limiting input to the process. Consequently, one of the principal objectives of this design effort was to maximize this value.

The next block, S2, simulates the duct that connects the hot side of the PCHX to the hot side of the SG. Secondary He coolant effluent from the PHX-HSQ (stream S4) is passed to Pipe block S2, which assumes a diameter of $800 \mathrm{~mm}$, a length of $15,400 \mathrm{~mm}$, and includes pipe entrance (flush, with an entrance $\mathrm{R} / \mathrm{D} \geq 0.15$ ) and exit losses as well as one large 90-degree elbow allowance. Stream S5 carries the secondary He coolant on to the SG. 
As in the case of PHX-HSQ, it is sufficient to treat the hot side of the steam generator, block SG-HS as a simple Heater block, specifying the pressure drop and the outlet temperature. A $42-\mathrm{kPa}(0.42$-bar) pressure drop for the hot side of the $\mathrm{SG}$ was agreed upon in consultation with Westinghouse, Shaw, and PBMR, and is imposed here. The temperature is set by Design Spec IHX-DT, which adjusts its value such that the temperature difference between the hot primary coolant feed to the IHX (stream P2) and the hot secondary coolant effluent (stream S2) is $50^{\circ} \mathrm{C}$. An iterative calculation is used to converge on a solution. The resulting SG-HS heat duty, calculated by energy balance and transferred to heat stream Q3, establishes the steam generation rate.

Cold secondary He coolant (stream S6) passes through Pipe block S3, which simulates the duct connecting the hot side of the steam generator to the secondary circulator. Block S3 assumes a diameter of $800 \mathrm{~mm}$, a length of $46,390 \mathrm{~mm}$, and includes a pipe entrance loss (flush, with an entrance $\mathrm{R} / \mathrm{D} \geq 0.15$ ) as well as four large 90-degree elbow allowances.

Steam S7 passes the effluent from Pipe block S3 to the Compr block (SC-1) that simulates the secondary circulator. Like the primary circulator, the secondary is assumed to operate with an isentropic efficiency of $80 \%$ and a mechanical efficiency of $95 \%$. Its discharge pressure is set to be 3.0 bar higher than that for PC-1 by calculator block IHX-DP. This results in an average pressure difference between the primary and the secondary coolants at the IHX of about 5 bar.

The circulator discharges cold secondary He coolant (stream S8) to the duct that connects it to the cold side inlet of the IHX (block S4), which is modeled as an adiabatic cylindrical pipe (Pipe block) with an inside diameter of $800 \mathrm{~mm}$, a length of 4,200 mm, and an exit loss allowance. Stream S9, which exits block S4, is used to provide new values of temperature and pressure for stream S1. Calculator block SEC-TEAR sets the temperature and pressure of stream S1 equal to the temperature and pressure of the stream S9, treating them as tear variables that can be converged iteratively. This completes the simulation of the secondary coolant loop, thereby finishing the simulation of the PBMR NHSS Reference Design flowsheet.

The performance of the Reference Design flowsheet is summarized in Table 4-1 below. Table 4-2 presents primary He coolant stream data and Table 4-3 tabulates stream data for the secondary He coolant.

\subsection{PRIMARY AND SECONDARY HEAT TRANSFER SYSTEM DESIGNS}

As noted above, one of the principal objectives of this PBMR NHSS HyS evaluation is to maximize the hydrogen production rate that could be achieved with a single PBMR module. The design variables that were available for manipulation were:

- Reactor outlet temperature, up to $950^{\circ} \mathrm{C}$, lower temperature not likely to benefit hydrogen production rate; 
Table 4-1 PBMR-NHSS Reference Design Performance

\begin{tabular}{|c|c|}
\hline Description & Value \\
\hline PBMR Inlet Temperature, ${ }^{\circ} \mathrm{C}$ & 350 \\
\hline PBMR Outlet Temperature, ${ }^{\circ} \mathrm{C}$ & 950 \\
\hline PBMR Heat Input into Primary Coolant, $\mathrm{MW}_{\text {th }}$ & 497 \\
\hline PBMR Heat Losses, $\mathrm{MW}_{\text {th }}$ & 3 \\
\hline PBMR Heat Output, $M_{\text {th }}$ & 500 \\
\hline Primary Circulator Discharge Pressure, bar & 90 \\
\hline Primary Circulator Power Requirement, $\mathrm{MW}_{\mathrm{e}}$ & 11.611 \\
\hline IHX Outlet Temperature, Secondary Coolant, ${ }^{\circ} \mathrm{C}$ & 900 \\
\hline IHX Heat Duty, $\mathrm{MW}_{\text {th }}$ & 508.03 \\
\hline PCHX Outlet Temperature, ${ }^{\circ} \mathrm{C}$ & 522.7 \\
\hline PCHX Heat Duty, MW ${ }_{\text {th }}$ & 312.79 \\
\hline SG Outlet Temperature, ${ }^{\circ} \mathrm{C}$ & 277.2 \\
\hline SG Heat Duty, $\mathrm{MW}_{\text {th }}$ & 203.50 \\
\hline Secondary Circulator Discharge Pressure, bar & 93 \\
\hline Secondary Circulator Power Requirement, $\mathrm{MW}_{\mathrm{e}}$ & 8.697 \\
\hline
\end{tabular}

Table 4-2 Primary He Coolant Stream Data for Reference Design Case ${ }^{4}$

\begin{tabular}{|l|r|r|r|r|r|}
\hline Stream Name: & P1/P6 & P2 & P3 & P4 & P5 \\
To Block: & P1 & IHX-HS & PC-1 & P3 & PBMR \\
From Block: & PBMR & P1 & IHX-HS & PC-1 & P3 \\
\hline Total Flow, kmol/s & 39.86 & 39.86 & 39.86 & 39.86 & 39.86 \\
Total Flow, kg/s & 159.55 & 159.55 & 159.55 & 159.55 & 159.55 \\
Total Flow, ${ }^{3} / \mathrm{s}$ & 47.33 & 47.36 & 24.40 & 23.92 & 23.99 \\
Temperature, ${ }^{\circ} \mathrm{C}$ & 950.00 & 950.01 & 337.09 & 349.97 & 350.00 \\
Pressure, bar & 87.45 & 87.39 & 86.34 & 90.00 & 89.73 \\
Vapor Fraction & 1 & 1 & 1 & 1 & 1 \\
Enthalpy, $\mathrm{kJ} / \mathrm{kmol}$ & 19437.4 & 19437.4 & 6692.2 & 6968.9 & 6968.9 \\
Enthalpy, $\mathrm{kJ} / \mathrm{kg}$ & 4856.2 & 4856.2 & 1672.0 & 1741.1 & 1741.1 \\
Enthalpy, $\mathrm{kW}$ & 774,783 & 774,783 & 266,752 & 277,783 & 277,783 \\
Density, $\mathrm{kmol} / \mathrm{m}^{3}$ & 0.84224 & 0.84164 & 1.63369 & 1.66629 & 1.66136 \\
Density, $\mathrm{kg} / \mathrm{m}^{3}$ & 3.3711 & 3.3687 & 6.5390 & 6.6695 & 6.6498 \\
\hline
\end{tabular}

\footnotetext{
${ }^{4}$ Stream and block references are to the Aspen Plus flowsheet model in Figure 4-3.
} 
Table 4-3 Secondary He Coolant Stream Data for Reference Design Case ${ }^{5}$

\begin{tabular}{|l|r|r|r|r|r|r|r|r|}
\hline Stream Name: & S1/S9 & S2 & S3 & S4 & S5 & S6 & S7 & S8 \\
To Block: & IHX-CS & S1 & PHX-HSQ & S2 & SG-HS & S3 & SC-1 & S4 \\
From Block: & S4 & IHX-CS & S1 & PHX-HSQ & S2 & SG-HS & S3 & SC-1 \\
\hline Total Flow, kmol/s & 39.86 & 39.86 & 39.86 & 39.86 & 39.86 & 39.86 & 39.86 & 39.86 \\
Total Flow, kg/s & 159.55 & 159.55 & 159.55 & 159.55 & 159.55 & 159.55 & 159.55 & 159.55 \\
Total Flow, $\mathrm{m}^{3} / \mathrm{s}$ & 20.95 & 43.32 & 43.46 & 30.12 & 30.16 & 21.25 & 21.28 & 20.93 \\
Temperature, ${ }^{\circ} \mathrm{C}$ & 286.85 & 900.01 & 900.04 & 522.70 & 522.72 & 277.24 & 277.25 & 286.85 \\
Pressure, bar & 92.93 & 91.81 & 91.51 & 90.51 & 90.38 & 89.96 & 89.86 & 93.00 \\
Vapor Fraction & 1 & 1 & 1 & 1 & 1 & 1 & 1 & 1 \\
Enthalpy, $\mathrm{kJ} / \mathrm{kmol}$ & 5663.6 & 18408.9 & 18408.9 & 10561.7 & 10561.7 & 5456.3 & 5456.3 & 5663.6 \\
Enthalpy, $\mathrm{kJ} / \mathrm{kg}$ & 1415.0 & 4599.2 & 4599.2 & 2638.7 & 2638.7 & 1363.2 & 1363.2 & 1415.0 \\
Enthalpy, $\mathrm{kW}$ & 225,754 & 733,785 & 733,785 & 420,994 & 420,994 & 217,492 & 217,492 & 225,754 \\
Density, $\mathrm{kmol} / \mathrm{m}^{3}$ & 1.90275 & 0.92013 & 0.91716 & 1.32360 & 1.32164 & 1.87547 & 1.87355 & 1.90414 \\
Density, $\mathrm{kg} / \mathrm{m}^{3}$ & 7.6160 & 3.6829 & 3.6710 & 5.2979 & 5.2900 & 7.5068 & 7.4991 & 7.6215 \\
\hline
\end{tabular}

- Primary He coolant pressure, nominally 90 bar at the primary circulator discharge, could be lowered to increase hydrogen production;

- Reactor inlet temperature, limited to maximum $350^{\circ} \mathrm{C}$ to enable use of SA 508 pressure boundary material without active cooling; could consider temperature increase if shown to increase hydrogen production substantially.

These were subject to the following constraints:

- Individual PBMR module thermal output, including losses to surroundings, limited to maximum $500 \mathrm{MW}_{\text {th }}$;

- Primary He coolant volumetric flow rate limited to maximum $54 \mathrm{~m}^{3} / \mathrm{s}$ at PBMR outlet.

In addition to these limitations, the needs of the Hybrid Sulfur Process have to be taken into account as well. As will be shown in Section 5.0 the hydrogen production process requires about $350 \mathrm{MW}_{\text {th }}$ of high-temperature heat for every $\mathrm{kmol} / \mathrm{s}$ of hydrogen production in order to drive the sulfuric acid decomposition reaction. This heat has to be supplied above the pinch temperature of the process, which imposes a third constraint. The pinch temperature depends on the details of the sulfuric acid decomposition process, and its determination will be documented in 5.0 Only the results of the pinch analyses will be applied here.

Eight cases were originally proposed for evaluation. These cases, which were established by consensus with SRNL, Westinghouse, Shaw, and PBMR, are detailed in Table 4-4 below. The first case is the Reference Design, for which performance data are presented above. Case 2 was intended to increases the PBMR inlet temperature to the point where the primary

\footnotetext{
${ }^{5}$ Stream and block references are to the Aspen Plus flowsheet model inFigure 4-3.
} 
He coolant volumetric flow rate at the PBMR outlet reached the $54-\mathrm{m}^{3} / \mathrm{s}$ upper limit. This was expected to result in a $75^{\circ} \mathrm{C}$ increase, to $425^{\circ} \mathrm{C}$. The advantage of this change was that a greater fraction of the $500-\mathrm{MW}_{\text {th }}$ output would be available above $500^{\circ} \mathrm{C}$ and could, therefore, be used for sulfuric acid decomposition, increasing the hydrogen production rate.

Table 4-4 Design Cases for Reference PBMR NHSS Flowsheet

\begin{tabular}{|c|c|c|c|c|c|c|c|c|c|c|c|}
\hline \multirow{2}{*}{$\begin{array}{l}\text { Case } \\
\text { No. }\end{array}$} & \multicolumn{6}{|c|}{ Temperature, ${ }^{\circ} \mathrm{C}$} & \multirow{2}{*}{$\begin{array}{l}\text { PBMR } \\
\text { Output, } \\
\text { MW }_{\text {th }}\end{array}$} & \multicolumn{2}{|c|}{ Pressure, $\mathrm{MPa}$} & \multicolumn{2}{|c|}{ He Flow } \\
\hline & $\begin{array}{c}\text { PBMR } \\
\text { inlet }\end{array}$ & $\begin{array}{c}\text { PBMR } \\
\text { outlet }\end{array}$ & $\begin{array}{l}\text { IHX } \\
\text { inlet }\end{array}$ & $\begin{array}{l}\text { IHX } \\
\text { outlet }\end{array}$ & $\begin{array}{c}\text { PCHX } \\
\text { inlet }\end{array}$ & $\begin{array}{l}\text { HyS } \\
\text { outlet }\end{array}$ & & $\begin{array}{c}\text { PBMR } \\
\text { inlet }\end{array}$ & $\begin{array}{c}\text { PBMR } \\
\text { outlet }\end{array}$ & $\mathrm{kg} / \mathrm{s}$ & $\mathrm{m}^{3} / \mathrm{s}$ \\
\hline 1 & 350 & 950 & 290 & 900 & 900 & 875 & 500 & 9 & 8.8 & 160 & 46.4 \\
\hline 2 & 425 & 950 & 365 & 900 & 900 & 875 & 500 & 9 & 8.8 & 182 & 54 \\
\hline 3 & 500 & 950 & 440 & 900 & 900 & 875 & 430 & 9 & 8.8 & 182 & 54 \\
\hline 4 & 500 & 950 & 440 & 900 & 900 & 875 & 300 & 6.3 & 6.1 & 127 & 54 \\
\hline 5 & 425 & 900 & 365 & 850 & 850 & 825 & 472 & 9 & 8.8 & 190 & 54 \\
\hline 6 & 500 & 900 & 440 & 850 & 850 & 825 & 400 & 9 & 8.8 & 190 & 54 \\
\hline 7 & 500 & 900 & 440 & 850 & 850 & 825 & 277 & 6.3 & 6.1 & 132 & 54 \\
\hline 8 & 500 & 950 & 450 & 900 & 900 & 875 & 365 & 7.75 & 7.55 & 184 & 54 \\
\hline
\end{tabular}

This idea was carried to the logical next step in Case 3 by raising the PBMR inlet temperature the rest of the way to $500^{\circ} \mathrm{C}$. All of the PBMR heat output would now conceivably be available for use in sulfuric acid decomposition, but the PBMR would have to be de-rated to an estimated $430-\mathrm{MW}_{\text {th }}$ output because the $54-\mathrm{m}^{3} / \mathrm{s}$ PBMR outlet volumetric flow rate limit would restrict the quantity of He that could be circulated through the core.

Case 4 starts at Case 3 conditions and drops the He coolant pressure from 9 to $6.3 \mathrm{MPa}$ to allow the sulfuric acid decomposition reaction to take place at lower pressure. This change was suggested by the observation that Le Châtelier's principle predicts lower pressure should help the decomposition equilibrium. However, the higher PBMR inlet temperature $\left(500^{\circ} \mathrm{C}\right)$ and the lower He coolant density at lower pressure combine to force a significant de-rating of the PBMR heat output, to only about $300 \mathrm{MW}_{\text {th }}$, in order to meet the PBMR coolant volumetric flow rate limit.

The $950^{\circ} \mathrm{C}$ PBMR outlet temperature specified for the Reference Design case has a significant impact on materials requirements (notably for the IHX, among other components), which translates into capital cost and longevity concerns. Lowering this value by $50^{\circ} \mathrm{C}$ could result in economic savings. Consequently, Cases 5, 6, and 7 were proposed as lower temperature alternatives to Cases 2, 3, and 4, being essentially identical except for lower PBMR outlet temperature of $900^{\circ} \mathrm{C}$. Decreasing the outlet temperature causes the quantity of heat that can be transferred to the coolant to be reduced as well, requiring further de-rating of the PBMR heat output. The estimated heat outputs for Cases 5, 6, and 7 are only 472,400 , and $277 \mathrm{MW}_{\text {th }}$, respectively.

Finally, Case 8 is a compromise between Cases 3 and 4. Instead of lowering the coolant pressure by $3.7 \mathrm{MPa}$, the pressure in Case 8 is lower than that in Case 3 by only half that 
amount. The PBMR inlet pressure is $7.75 \mathrm{MPa}$. This also means that the PBMR heat output has to be de-rated by only half as much - from 430 to $365 \mathrm{MW}_{\text {th }}$.

\subsection{PERFORMANCE SUMMARY OF DESIGN CASES}

The Aspen Plus model described in Section 4.2 above was run for all eight cases listed in Table 4-4. Pinch temperatures for the PCHX, which depended on pressure and peak process temperature, were calculated from the detailed model of the HyS Decomposition Reactor, as described in TBD, and substituted into the PBMR NHSS Flowsheet model. The results are contained in Table 4-5 below.

Table 4-5 Performance Summary for the PBMR-NHSS Design Cases

\begin{tabular}{|c|c|c|c|c|c|c|c|c|c|}
\hline \multirow{2}{*}{$\begin{array}{l}\text { Case } \\
\text { No. }\end{array}$} & \multicolumn{4}{|c|}{ Temperature, ${ }^{\circ} \mathrm{C}$} & \multicolumn{2}{|c|}{ Pressure, $\mathrm{MPa}$} & \multirow{2}{*}{$\begin{array}{l}\text { PBMR } \\
\text { Output, } \\
\text { MW }_{\text {th }}\end{array}$} & \multicolumn{2}{|c|}{ He Flow } \\
\hline & $\begin{array}{c}\text { PBMR } \\
\text { inlet }\end{array}$ & $\begin{array}{c}\text { PBMR } \\
\text { outlet }\end{array}$ & $\begin{array}{l}\text { IHX } \\
\text { inlet }\end{array}$ & $\begin{array}{c}\text { IHX } \\
\text { outlet }\end{array}$ & $\begin{array}{c}\text { PBMR } \\
\text { inlet }\end{array}$ & $\begin{array}{c}\text { PBMR } \\
\text { outlet }\end{array}$ & & $\mathrm{kg} / \mathrm{s}$ & $\mathrm{m}^{3} / \mathrm{s}$ \\
\hline 0 & 350.0 & 950.0 & 286.9 & 900.0 & 8.973 & 8.745 & 500.0 & 159.5 & 47.3 \\
\hline 1 & 350.0 & 950.0 & 286.9 & 900.0 & 8.973 & 8.745 & 500.0 & 159.5 & 47.3 \\
\hline $1 \mathrm{R}$ & 350.0 & 950.0 & 284.2 & 900.0 & 7.904 & 7.645 & 500.0 & 159.6 & 54.0 \\
\hline 2 & 418.9 & 950.0 & 350.8 & 900.0 & 8.961 & 8.659 & 500.0 & 180.3 & 54.0 \\
\hline 3 & 500.0 & 950.0 & 429.2 & 900.0 & 8.957 & 8.643 & 423.3 & 180.0 & 54.0 \\
\hline 4 & 500.0 & 950.0 & 429.3 & 900.0 & 6.270 & 6.049 & 299.0 & 126.7 & 54.0 \\
\hline 5 & 425.0 & 900.0 & 356.0 & 850.0 & 8.958 & 8.638 & 464.9 & 187.4 & 54.0 \\
\hline 6 & 500.0 & 900.0 & 428.3 & 850.0 & 8.954 & 8.622 & 391.2 & 187.0 & 54.0 \\
\hline 7 & 500.0 & 900.0 & 428.3 & 850.0 & 6.267 & 6.034 & 276.5 & 131.7 & 54.0 \\
\hline 8 & 500.0 & 950.0 & 429.2 & 900.0 & 7.713 & 7.442 & 365.9 & 155.4 & 54.0 \\
\hline
\end{tabular}

\begin{tabular}{|c|c|c|c|c|c|c|c|c|c|}
\hline \multirow{2}{*}{$\begin{array}{l}\text { Case } \\
\text { No. }\end{array}$} & \multicolumn{3}{|c|}{ Temperature, ${ }^{\circ} \mathrm{C}$} & \multirow{2}{*}{$\begin{array}{c}\text { HyS } \\
\text { press., } \\
\mathrm{MPa}\end{array}$} & \multicolumn{2}{|c|}{ Power, $\mathrm{MW}_{\mathrm{e}}$} & \multicolumn{2}{|c|}{ Duties, $\mathrm{MW}_{\text {th }}$} & \multirow{2}{*}{$\begin{array}{c}\mathrm{H}_{2} \text { rate, } \\
\mathrm{kmol} / \\
\mathrm{hr}\end{array}$} \\
\hline & $\begin{array}{c}\text { PCHX } \\
\text { inlet }\end{array}$ & $\begin{array}{l}\text { PCHX } \\
\text { outlet }\end{array}$ & $\begin{array}{c}\text { Peak } \\
\text { HyS }\end{array}$ & & $\begin{array}{l}\text { Prim. } \\
\text { Circ. }\end{array}$ & $\begin{array}{l}\text { Sec. } \\
\text { Circ. }\end{array}$ & PCHX & SG & \\
\hline 0 & 900.0 & 659.0 & 875.0 & 8.7 & 11.6 & 8.8 & 199.8 & 316.5 & 1,322 \\
\hline 1 & 900.0 & 522.7 & 870.0 & 8.6 & 11.6 & 8.7 & 312.8 & 203.5 & 3,309 \\
\hline $1 \mathrm{R}$ & 900.0 & 509.3 & 870.0 & 7.6 & 13.9 & 9.6 & 323.9 & 195.4 & 3,382 \\
\hline 2 & 900.1 & 522.7 & 870.0 & 8.6 & 18.0 & 11.6 & 353.4 & 171.6 & 3,739 \\
\hline 3 & 900.1 & 522.7 & 870.0 & 8.6 & 20.7 & 13.0 & 352.8 & 99.5 & 3,733 \\
\hline 4 & 900.0 & 478.7 & 870.0 & 5.9 & 14.5 & 10.6 & 277.4 & 42.5 & 2,813 \\
\hline 5 & 850.1 & 545.8 & 820.0 & 8.6 & 19.8 & 12.3 & 296.2 & 196.1 & 3,042 \\
\hline 6 & 850.1 & 545.8 & 820.0 & 8.6 & 22.5 & 13.7 & 295.7 & 126.9 & 3,037 \\
\hline 7 & 850.0 & 501.8 & 820.0 & 5.9 & 15.7 & 11.1 & 238.3 & 60.7 & 2,349 \\
\hline 8 & 900.0 & 500.7 & 870.0 & 7.35 & 17.8 & 11.9 & 322.4 & 68.8 & 3,339 \\
\hline
\end{tabular}


A quick inspection of Table 4-5 shows two additional cases are included - cases 0 and $1 \mathrm{R}$. Case 0 is the PHP 1A Reference Design that was the basis for the NGNP Preconceptual Design [15]. As such, it represents the hydrogen production rate that was attainable with the HyS flowsheet proposed by Westinghouse for NGNP. Case $1 \mathrm{R}$ is a late addition identical to Case 1 except that the primary He coolant pressure has been reduced to the point where the PBMR outlet flow rate just reaches its $54-\mathrm{m}^{3} / \mathrm{s}$ upper limit.

Looking at the last column in the bottom half of Table 4-5, the new HyS flowsheet coupled to the PBMR NHSS at Reference Design conditions (Case 1) produces two-and-a-half times more hydrogen $(3,309 \mathrm{kmol} / \mathrm{hr})$ than the original Westinghouse flowsheet (Case 0, 1,322 $\mathrm{kmol} / \mathrm{hr}$ ). Two factors are responsible for this improvement: 1) 56\% more high-temperature heat is being used for sulfuric acid decomposition ( $\mathrm{PCHX}$ outlet temperature of $522.7^{\circ} \mathrm{C}$ instead of $659.0^{\circ} \mathrm{C}$ ), and 2) $37 \%$ less high-temperature heat is needed per mole of hydrogen product $(340.3 \mathrm{~kJ} / \mathrm{gmol} \mathrm{H}$ for the new HyS flowsheet instead of the original $544.0 \mathrm{~kJ} / \mathrm{gmol}$ $\mathrm{H}_{2}$ ). More information about these changes can be found in Section 5.0. Of course, the increase in the amount of heat being used for hydrogen production $\left(+113 \mathrm{MW}_{\text {th }}\right)$ is offset by a decrease in the steam generation rate $\left(-113 \mathrm{MW}_{\mathrm{th}}\right)$. However, hydrogen is assumed to be the more valuable product.

The highest hydrogen production rate is achieved by Case 2. Simply raising the PBMR inlet temperature 68.9 degrees, from $350^{\circ} \mathrm{C}$ to $418.9^{\circ} \mathrm{C}$, results in a $13 \%$ increase in hydrogen production over Case 1. However, as Case 3 demonstrates, further raising the PBMR inlet temperature beyond $418.9^{\circ} \mathrm{C}$ does not have a beneficial effect. This is because any increase in the fraction of heat output that is being applied to high-temperature sulfuric acid decomposition is offset by the need to de-rate the PBMR to stay within the $54-\mathrm{m}^{3} / \mathrm{s}$ PBMR outlet flow rate limit.

Case $1 \mathrm{R}$ was prompted by the observation during development of the HyS flowsheet, as noted in Section 5.0, that lower sulfuric acid decomposition process pressures give lower pinch temperatures. As seen in Table 4-5, the PCHX outlet temperature can be decreased from $522.7^{\circ} \mathrm{C}$ to $509.3^{\circ} \mathrm{C}$ without having to de-rate the PBMR by decreasing the peak HyS process pressure from 8.6 to $7.6 \mathrm{MPa}$. This increases the quantity of high-temperature heat available for sulfuric acid decomposition by $3.5 \%$. However, some of this gain is offset by an increase in the high-temperature heat demand per mole of hydrogen product at the lower pressure. The net result is only a $2.2 \%$ increase in hydrogen production rate, from 3,309 to $3,382 \mathrm{kmol} / \mathrm{hr}$.

Of the remaining cases (4 through 8) all are at higher PBMR inlet temperature than Case 1. All but Case 8 have lower hydrogen production rates, so there is really no incentive to consider them any further. Case 8 has a just slightly higher hydrogen production rate than Case 1, but at the expense of de-rating the PBMR from 500 to $365.9 \mathrm{MW}_{\text {th }}$ and not without raising the $\mathrm{PBMR}$ inlet temperature all the way to $500^{\circ} \mathrm{C}$. 


\subsection{DISCUSSION}

For a reactor inlet temperature (RIT) of $350^{\circ} \mathrm{C}$, Case 1 produces 2.5 times more hydrogen than the reference Case 0 . This is because a re-design of the decomposition reactor dramatically reduced the heat requirement per mole of $\mathrm{SO}_{2}$ produced. In addition, electrical generation was sacrificed to maximize hydrogen production. Compared to the reference Case 0 , the implications on the flow sheet economics are that the cost of hydrogen is dramatically reduced. Hence, for a RIT of $350^{\circ} \mathrm{C}$ it is recommended that Case 1 be the reference, and as such Case 1 is the Reference Design that is represented in Sections 4.1 and 4.2. Reference Design hydrogen output is therefore $3,309 \mathrm{kmol} / \mathrm{hr}$ (in other units often used: $1.85 \mathrm{~kg} / \mathrm{s}, 160.1 \mathrm{MT} / \mathrm{day}, 66.2 \mathrm{mscf} / \mathrm{d}, 74,200 \mathrm{Nm}^{3} / \mathrm{h}$ ). While Case $1 \mathrm{R}$ resulted in slightly higher hydrogen output than Case 1, it was not selected because it necessitated changes to the baseline PBMR operating conditions.

For RITs higher than $350^{\circ} \mathrm{C}$, Case 2 offers the highest hydrogen output. The use of SA508 implies that the pressure boundary temperature needs to be limited to below $371^{\circ} \mathrm{C}$. Hence, the higher RIT implies additional capital costs associated with pressure boundary cooling equipment and larger circulators; and also additional operational costs (circulator power) and efficiency losses due to active cooling. Case 2 also offers increased risk. Further evaluation of the impact of the reactor design changes necessitated by Case 2 was beyond the scope of this study. A detailed economic comparison, including evaluation of HyS flowsheet implications, remains to indicate whether Case 1 or Case 2 is the better option. The consensus reached between SRNL, Westinghouse, Shaw, and PBMR was to proceed with Case 1 for the remainder of this study. 


\subsection{HYBRID SULFUR PROCESS FLOWSHEET}

\subsection{INTEGRATING THE DECOMPOSITION REACTOR WITH A PEM SDE}

It is assumed that the SDE anolyte product is $50-\mathrm{wt}^{2} \% \mathrm{H}_{2} \mathrm{SO}_{4}$ at $100^{\circ} \mathrm{C}(373 \mathrm{~K})$ and 20 bar, and that it contains unreacted $\mathrm{SO}_{2}$ as well as traces of $\mathrm{O}_{2}$. (Higher temperatures give better kinetics, but can't be tolerated by perfluoropolymer PEMs. Higher pressures favor $\mathrm{SO}_{2}$ solubility, but are limited by $\mathrm{SO}_{2}$ vapor pressure - two liquid phases could otherwise form in the SDE in some circumstances.) To integrate the SDE with a Decomposition Reactor, most of the anolyte will need to be recycled. The remaining product stream, containing one mole of $\mathrm{H}_{2} \mathrm{SO}_{4}$ for each mole of $\mathrm{H}_{2}$ produced in the SDE, will be passed on. Unreacted $\mathrm{SO}_{2}$ and trace $\mathrm{O}_{2}$ will first need to be removed from this stream, along with about one-third (to yield $60 \mathrm{wt} \% \mathrm{H}_{2} \mathrm{SO}_{4}$ ) to three-quarters (to yield $80 \mathrm{wt} \% \mathrm{H}_{2} \mathrm{SO}_{4}$ ) of the water content. Similarly, the bayonet product will have to be cooled, unreacted $\mathrm{H}_{2} \mathrm{SO}_{4}$ recycled, $\mathrm{O}_{2}$ removed, and the remaining $\mathrm{SO}_{2}$ and water condensed and combined with recycled, spent anolyte to form fresh anolyte feed.

The simplest way to remove unreacted $\mathrm{SO}_{2}$ and trace $\mathrm{O}_{2}$ from the SDE product is to drop the pressure. This requires recompressing the predominantly $\mathrm{SO}_{2}$ and trace $\mathrm{O}_{2}$ vapor stream that is out-gassed so that it can be recycled to the SDE feed system. The shaft work required is not excessive and the separation can be made without any heat input.

A variety of methods are available for concentrating the degassed SDE product. All require the expenditure of energy, some more than others. For example, $50 \% \mathrm{H}_{2} \mathrm{SO}_{4}$ at $100^{\circ} \mathrm{C}(373$ $\mathrm{K}$ ) and 20 bar can be concentrated to $75 \% \mathrm{H}_{2} \mathrm{SO}_{4}$ by simply dropping the pressure to just under 0.05 bar while maintaining the temperature at $100^{\circ} \mathrm{C}(373 \mathrm{~K})$ requiring just over 169 $\mathrm{kJ} / \mathrm{mol} \mathrm{H}_{2} \mathrm{SO}_{4}$ heat input. Water boils off as a separate vapor phase. The pressure could also be maintained at 20 bar and the SDE product heated to $317^{\circ} \mathrm{C}(590 \mathrm{~K})$ instead to boil off the water. This would take just over $246 \mathrm{~kJ} / \mathrm{mol} \mathrm{H}_{2} \mathrm{SO}_{4}$ heat input. In either case, the heat required is excessive, and would cause the sum of the acid concentration and decomposition step heat duties to exceed the $450-\mathrm{kJ} / \mathrm{mol} \mathrm{H}_{2}$ practical upper limit before even considering the recycled undecomposed acid concentration step. It is clear that a recuperative method is necessary.

Vacuum distillation with recuperative preheating/partial vaporization of the feed streams was chosen to concentrate the SDE product. A two-stage steam ejector can be used to maintain column pressure, while temperatures can be kept high enough to allow use of cooling water in the condenser, yet low enough to allow metallic materials of construction. Water removed in the concentration process can be condensed and recycled to the SDE feed system. The vacuum column bottoms, containing concentrated sulfuric acid, can be easily pumped to the necessary pressure and fed directly to the Decomposition Reactor. 
The Decomposition Reactor effluent can be readily separated into unreacted $\mathrm{H}_{2} \mathrm{SO}_{4}$ feed and the $\mathrm{SO}_{2} / \mathrm{O}_{2}$ product by doing a vapor/liquid split. The acid can be recycled to the vacuum still, while the vapor can be further cooled and let down to the SDE pressure. This will result in a three-phase system: wet liquid $\mathrm{SO}_{2}$, a saturated solution of $\mathrm{SO}_{2}$ in $\mathrm{H}_{2} \mathrm{O}$, and wet $\mathrm{O}_{2}$ gas contaminated with $\mathrm{SO}_{2}$. The $\mathrm{O}_{2}$ gas can be scrubbed with the water collected in the concentration process to remove most of the $\mathrm{SO}_{2}$. The two liquid phases can then be combined with that water and with recycled, spent anolyte to form fresh anolyte feed.

An important consideration is that since the SDE and Decomposition Reactor already pose significant technological challenges by themselves, the balance of the flowsheet should not introduce additional technical hurdles, but should only use proven technology. This will help give performance projections much greater credibility. The aforementioned flowsheet choices accomplish this goal.

\subsection{THE PEM SDE / DECOMPOSITION REACTOR HYBRID SULFUR FLOWSHEET}

An Aspen Plus flowsheet was prepared that incorporates the elements described in the preceding section. This flowsheet is illustrated in Figure 5-1. Stream compositions and conditions are detailed in Table 5-1. The basis is a $1-\mathrm{kmol} / \mathrm{sec} \mathrm{H}_{2}$ production rate.

The flowsheet simulations were done using OLI Systems, Inc.'s Mixed Solvent Electrolyte (MSE) model, which has been shown to represent the $\mathrm{H}_{2} \mathrm{SO}_{4}-\mathrm{H}_{2} \mathrm{O}$ system very well over its entire composition range and at temperatures as high as $500^{\circ} \mathrm{C}(773 \mathrm{~K})$ [16]. (The AspenOLI interface allows use of the OLI Engine from within Aspen Plus.) Spot checks of the OLI MSE model's representations of $\mathrm{SO}_{2}-\mathrm{H}_{2} \mathrm{O}$ and $\mathrm{SO}_{2}-\mathrm{H}_{2} \mathrm{SO}_{4}-\mathrm{H}_{2} \mathrm{O}$ vapor-liquid and liquidliquid equilibria against the available data showed generally good agreement (e.g. see Figure 5-2 [17,18,19] and Figure 5-3 [20,21,22]). 


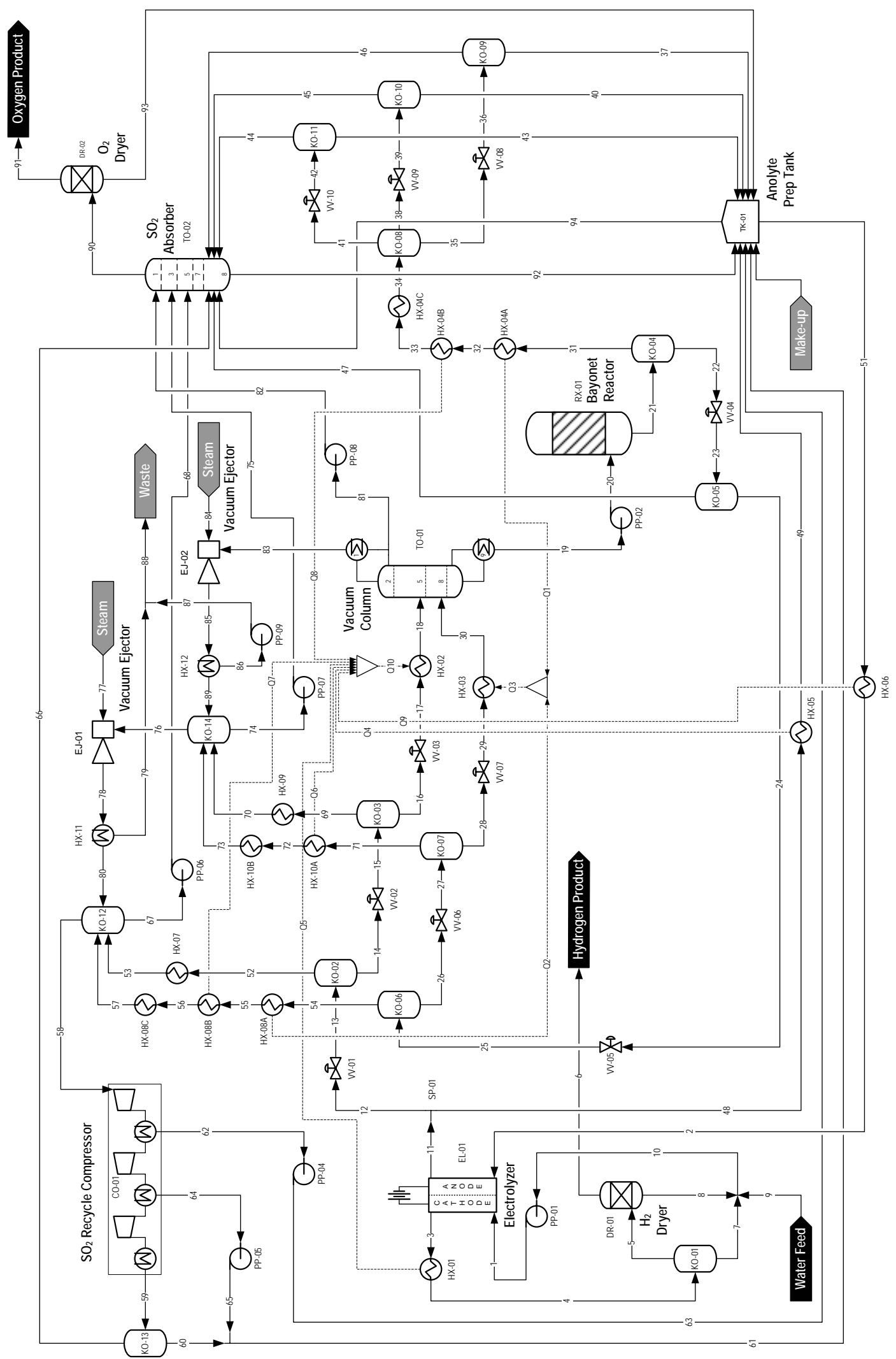

Figure 5-1 HyS flowsheet using a PEM SDE and a bayonet decomposition reactor 
Table 5-1 HyS flowsheet stream table

\begin{tabular}{|c|c|c|c|c|c|c|c|c|c|c|}
\hline \multirow{2}{*}{$\begin{array}{l}\text { Stream } \\
\text { ID }\end{array}$} & \multicolumn{6}{|c|}{ Molar flow rates, $\mathrm{kmol} / \mathrm{sec}$} & \multicolumn{2}{|c|}{ Temperature, } & \multirow{2}{*}{$\begin{array}{c}\text { Pressure, } \\
\text { bar }\end{array}$} & \multirow{2}{*}{ Phase } \\
\hline & $\mathrm{H}_{2} \mathrm{O}$ & $\mathrm{H}_{2} \mathrm{SO}_{4}$ & $\mathrm{SO}_{2}$ & $\mathrm{O}_{2}$ & $\mathrm{H}_{2}$ & Total & ${ }^{\circ} \mathrm{C}$ & ${ }^{\circ} \mathrm{K}$ & & \\
\hline 1 & 10 & 0 & 0 & 0 & 0.00235 & 10.0024 & 73.20 & 346.35 & 21 & $\mathrm{~L}$ \\
\hline 2 & 27.4794 & 88405 & 2.5 & 0.00527 & 0 & 37.7528 & 78.77 & 351.92 & 21 & $\mathrm{~L}$ \\
\hline 3 & 9 & 0 & 0 & 0 & 1.00235 & 10.0024 & 100.00 & 373.15 & 20 & $\mathrm{~L}+\mathrm{V}$ \\
\hline 4 & 9 & 0 & 0 & 0 & 1.00235 & 10.0024 & 76.96 & 350.11 & 20 & $\mathrm{~L}+\mathrm{V}$ \\
\hline 5 & 0.02185 & 0 & 0 & 0 & 1.00004 & 1.02189 & 76.96 & 350.11 & 20 & $\mathrm{~V}$ \\
\hline 6 & 0 & 0 & 0 & 0 & 1.00004 & 1.00004 & 40.00 & 313.15 & 20 & $\mathrm{~V}$ \\
\hline 7 & 8.97815 & 0 & 0 & 0 & 0.00231 & 8.98046 & 76.96 & 350.11 & 20 & $\mathrm{~L}$ \\
\hline 8 & 0.02185 & 0 & 0 & 0 & 0 & 0.02185 & 40.00 & 313.15 & 20 & $\mathrm{~L}$ \\
\hline 9 & 1 & 0 & 0 & 0 & 0 & 1 & 40.00 & 313.15 & 20 & $\mathrm{~L}$ \\
\hline 10 & 10 & 0 & 0 & 0 & 0.00231 & 10.0023 & 73.19 & 346.34 & 20 & $\mathrm{~L}$ \\
\hline 11 & 26.4794 & 4.88405 & 1.5 & 0.00527 & 0 & 37.7528 & 100.00 & 373.15 & 20 & $\mathrm{~L}+\mathrm{V}$ \\
\hline 12 & 5.42394 & 1.00043 & 0.30725 & 0.00108 & 0 & 314 & 100.00 & 373.15 & 20 & $L+V$ \\
\hline 13 & 5.42394 & 1.00043 & 0.30725 & 0.00108 & 0 & 314 & 84.08 & 357.23 & 1.01325 & $\mathrm{~L}+\mathrm{V}$ \\
\hline 14 & 5.33174 & 1.00043 & 0.02004 & $3.9 \mathrm{E}-07$ & 0 & 7.35265 & 84.08 & 357.23 & 1.01325 & $\mathrm{~L}$ \\
\hline 15 & 5.33174 & 1.00043 & 0.02004 & $3.9 \mathrm{E}-07$ & 0 & 7.35265 & 80.38 & 353.53 & 0.30198 & $L+V$ \\
\hline 16 & 5.29406 & 1.00043 & 0.00263 & $2.9 \mathrm{E}-10$ & 0 & 7.29756 & 80.38 & 353.53 & 0.30198 & $\mathrm{~L}$ \\
\hline 17 & 5.29406 & 1.00043 & 0.00263 & $2.9 \mathrm{E}-10$ & 0 & 7.29756 & 66.96 & 340.11 & 0.11 & $L+V$ \\
\hline 18 & 5.29406 & 1.00043 & 0.00263 & $2.9 \mathrm{E}-10$ & 0 & 7.29756 & 94.41 & 367.56 & 0.11 & $L+V$ \\
\hline 19 & 3.7702 & 2.07782 & $6.7 \mathrm{E}-12$ & $2 \mathrm{E}-21$ & 0 & 7.92584 & 122.87 & 396.02 & 0.13 & $\mathrm{~L}$ \\
\hline 20 & 3.7702 & 2.07782 & $6.7 \mathrm{E}-12$ & 0 & 0 & 7.92584 & 123.63 & 396.78 & 86 & $\mathrm{~L}$ \\
\hline 21 & 4.77063 & 1.07739 & 1.00043 & 0.50021 & 0 & 8.42605 & 254.70 & 527.85 & 86 & $\mathrm{~L}+\mathrm{V}$ \\
\hline 22 & 4.30695 & 1.07739 & 0.23587 & 0.00844 & 0 & 6.70604 & 254.70 & 527.85 & 86 & $\mathrm{~L}$ \\
\hline 23 & 4.30695 & 1.07739 & 0.23587 & 0.00844 & 0 & 6.70604 & 233.42 & 506.57 & 21 & $\mathrm{~L}+\mathrm{V}$ \\
\hline 24 & 4.03002 & 1.07739 & 0.04733 & 8.9E-05 & 0 & 6.23222 & 233.42 & 506.57 & 21 & $\mathrm{~L}$ \\
\hline 25 & 4.03002 & 1.07739 & 0.04733 & 8.9E-05 & 0 & 222 & 147.33 & 420.48 & .01325 & $\mathrm{~L}+\mathrm{V}$ \\
\hline 26 & 3019 & 1.07739 & 0.00035 & $1.4 \mathrm{E}-08$ & 0 & 532 & 147.33 & 420.48 & 1.01325 & $\mathrm{~L}$ \\
\hline 27 & 3019 & 1.07739 & 0.00035 & $1.4 \mathrm{E}-08$ & 0 & 32 & 118.57 & .72 & 0.30198 & $L+V$ \\
\hline 28 & 2.87261 & 1.07739 & $3.7 \mathrm{E}-06$ & $2.4 \mathrm{E}-12$ & 0 & 39 & 118.57 & 391.72 & 0.30198 & $\mathrm{~L}$ \\
\hline 29 & 261 & 7739 & 66 & 2 & 0 & 39 & 100.50 & 373.65 & & $\mathrm{~L}+\mathrm{V}$ \\
\hline 30 & 61 & 1.07739 & -06 & E-12 & 0 & 5.02739 & 114.62 & 387.77 & 0.13 & $\mathrm{~L}+\mathrm{V}$ \\
\hline 31 & 0.46368 & $5.5 \mathrm{E}-06$ & 0.76455 & 0.49177 & 0 & 1.72001 & 254.70 & 527.85 & 86 & V \\
\hline 32 & 0.46368 & $5.5 \mathrm{E}-06$ & 0.76455 & 0.49177 & 0 & 1.72002 & 110.50 & 383.65 & 86 & $L+V$ \\
\hline 33 & 0.46368 & $5.5 \mathrm{E}-06$ & 0.76455 & 0.49177 & 0 & 1.72002 & 76.96 & 350.11 & 86 & $\mathrm{~L}+\mathrm{V}$ \\
\hline 34 & 0.46368 & $5.5 \mathrm{E}-06$ & 0.76455 & 0.49177 & 0 & 1.72002 & 40.00 & 313.15 & 86 & $\mathrm{~L}+\mathrm{V}$ \\
\hline 35 & 0.08967 & $1.8 \mathrm{E}-07$ & 0.65507 & 0.00123 & 0 & 0.74597 & 40.00 & 313.15 & 86 & $\mathrm{~L}$ \\
\hline 36 & 0.08967 & $1.8 \mathrm{E}-07$ & 0.65507 & 0.00123 & 0 & 0.74597 & 41.78 & 314.93 & 21 & $\mathrm{~L}+\mathrm{V}$ \\
\hline 37 & 0.08966 & $1.8 \mathrm{E}-07$ & 0.65459 & 0.00025 & 0 & 0.74451 & 41.78 & 314.93 & 21 & $\mathrm{~L}$ \\
\hline
\end{tabular}




\begin{tabular}{|c|c|c|c|c|c|c|c|c|c|c|}
\hline 38 & 0.37282 & $5.3 \mathrm{E}-06$ & 0.03946 & 0.00066 & 0 & 0.41296 & 40.00 & 313.15 & 86 & $\mathrm{~L}$ \\
\hline 39 & 0.37282 & $5.3 \mathrm{E}-06$ & 0.03946 & 0.00066 & 0 & 0.41296 & 40.99 & 314.14 & 21 & $\mathrm{~L}+\mathrm{V}$ \\
\hline 40 & 0.37282 & $5.3 \mathrm{E}-06$ & 0.03922 & 0.00014 & 0 & 0.41218 & 40.99 & 314.14 & 21 & $\mathrm{~L}$ \\
\hline 41 & 0.00119 & 0 & 0.07002 & 0.48988 & 0 & 0.56109 & 40.00 & 313.15 & 86 & $\mathrm{~V}$ \\
\hline 42 & 0.00119 & 0 & 0.07002 & 0.48988 & 0 & 0.56109 & 15.50 & 288.65 & 21 & $\mathrm{~L}+\mathrm{V}$ \\
\hline 43 & 0.0006 & 0 & $4.7 \mathrm{E}-05$ & $3.8 \mathrm{E}-07$ & 0 & 0.00065 & 15.50 & 288.65 & 21 & $\mathrm{~L}$ \\
\hline 44 & 0.00059 & 0 & 0.06997 & 0.48988 & 0 & 0.56044 & 15.50 & 288.65 & 21 & $\mathrm{~V}$ \\
\hline 45 & $3.5 \mathrm{E}-06$ & $4.3 \mathrm{E}-26$ & 0.00025 & 0.00052 & 0 & 0.00077 & 40.99 & 314.14 & 21 & $\mathrm{~V}$ \\
\hline 46 & $6.9 \mathrm{E}-06$ & $1 \mathrm{E}-25$ & 0.00048 & 0.00098 & 0 & 0.00146 & 41.78 & 314.93 & 21 & V \\
\hline 47 & 0.27692 & $1.3 \mathrm{E}-06$ & 0.18854 & 0.00835 & 0 & 0.47382 & 233.42 & 506.57 & 21 & $\mathrm{~V}$ \\
\hline 48 & 21.0554 & 3.88362 & 1.19275 & 0.00419 & 0 & 30.0196 & 100.00 & 373.15 & 20 & $\mathrm{~L}+\mathrm{V}$ \\
\hline 49 & 21.0554 & 3.88362 & 1.19275 & 0.00419 & 0 & 30.0196 & 80.00 & 353.15 & 20 & $\mathrm{~L}$ \\
\hline 50 & 21.0554 & 3.88362 & 1.19275 & 0.00419 & 0 & 30.0196 & 80.01 & 353.16 & 21 & $\mathrm{~L}$ \\
\hline 51 & 27.4794 & 3.88405 & 2.5 & 0.00524 & 0 & 37.7527 & 84.71 & 357.86 & 21 & $\mathrm{~L}$ \\
\hline 52 & 0.0922 & $2 \mathrm{E}-11$ & 0.28721 & 0.00108 & 0 & 0.38049 & 84.08 & 357.23 & 1.01325 & $\mathrm{~V}$ \\
\hline 53 & 0.0922 & $2 \mathrm{E}-11$ & 0.28721 & 0.00108 & 0 & 0.38049 & 40.00 & 313.15 & 1.01325 & $\mathrm{~L}+\mathrm{V}$ \\
\hline 54 & 0.89983 & $6.6 \mathrm{E}-07$ & 0.04698 & $8.9 \mathrm{E}-05$ & 0 & 0.9469 & 147.33 & 420.48 & 1.01325 & $\mathrm{~V}$ \\
\hline 55 & 0.89983 & $6.6 \mathrm{E}-07$ & 0.04698 & $8.9 \mathrm{E}-05$ & 0 & 0.9469 & 110.50 & 383.65 & 1.01325 & $\mathrm{~L}+\mathrm{V}$ \\
\hline 56 & 0.89983 & $6.6 \mathrm{E}-07$ & 0.04698 & $8.9 \mathrm{E}-05$ & 0 & .9469 & 76.96 & 350.11 & 1.01325 & $\mathrm{~L}+\mathrm{V}$ \\
\hline 57 & 0.89983 & $6.6 \mathrm{E}-07$ & 0.04698 & $8.9 \mathrm{E}-05$ & 0 & .9469 & 40.00 & 313.15 & 1.01325 & $\mathrm{~L}+\mathrm{V}$ \\
\hline 58 & 0.02674 & $2.3 \mathrm{E}-24$ & 0.33759 & 0.00117 & 0 & 0.3655 & 40.00 & 313.15 & 1.01325 & $\mathrm{~V}$ \\
\hline 59 & $1.9 \mathrm{E}-05$ & 0 & 0.00541 & 116 & 0 & 0.00659 & 40.00 & 313.15 & 21 & $\mathrm{~L}+\mathrm{V}$ \\
\hline 60 & E-05 & 0 & 18 & -06 & 0 & 482 & 40.00 & 15 & 21 & $\mathrm{~L}$ \\
\hline 61 & 0936 & 0 & 626 & 5 & 0 & 562 & 41.20 & .35 & 21 & $\mathrm{~L}$ \\
\hline 62 & 738 & 0 & 73 & -09 & 0 & 811 & 40.00 & .15 & 2.78324 & $\mathrm{~L}$ \\
\hline 63 & 38 & 0 & & 09 & 0 & 811 & 41.11 & .26 & 21 & $\mathrm{~L}$ \\
\hline 64 & 34 & 0 & 46 & 06 & 0 & & 40.00 & 15 & 7.64513 & $\mathrm{~L}$ \\
\hline 65 & 0.00934 & 0 & 0.33146 & $9.2 \mathrm{E}-06$ & 0 & .3408 & 41.22 & 314.37 & 21 & $\mathrm{~L}$ \\
\hline 66 & $3.2 \mathrm{E}-07$ & 0 & 0.00061 & 0.00116 & 0 & 0.00177 & 40.00 & 313.15 & 21 & $\mathrm{~V}$ \\
\hline 67 & 0.96665 & $6.6 \mathrm{E}-07$ & 0.01365 & $6.1 \mathrm{E}-08$ & 0 & 0.9803 & 40.00 & 313.15 & 1.01325 & $\mathrm{~L}$ \\
\hline 68 & 0.96665 & $6.6 \mathrm{E}-07$ & 0.01365 & $6.1 \mathrm{E}-08$ & 0 & 0.9803 & 40.31 & 313.46 & 21 & $\mathrm{~L}$ \\
\hline 69 & 0.03768 & $6.4 \mathrm{E}-12$ & 0.01741 & $3.9 \mathrm{E}-07$ & 0 & 0.0551 & 80.38 & 353.53 & 0.30198 & $\mathrm{~V}$ \\
\hline 70 & 0.03768 & $6.4 \mathrm{E}-12$ & 0.01741 & $3.9 \mathrm{E}-07$ & 0 & 0.0551 & 40.00 & 313.15 & 0.30198 & $\mathrm{~L}+\mathrm{V}$ \\
\hline 71 & 0.25758 & 1E-07 & 0.00035 & $1.4 \mathrm{E}-08$ & 0 & 0.25793 & 118.57 & 391.72 & 0.30198 & $\mathrm{~V}$ \\
\hline 72 & 0.25758 & $1 \mathrm{E}-07$ & 0.00035 & $1.4 \mathrm{E}-08$ & 0 & 0.25793 & 76.96 & 350.11 & 0.30198 & $\mathrm{~L}+\mathrm{V}$ \\
\hline 73 & 0.25758 & $1 \mathrm{E}-07$ & 0.00035 & $1.4 \mathrm{E}-08$ & 0 & 0.25793 & 40.00 & 313.15 & 0.30198 & $\mathrm{~L}$ \\
\hline 74 & 0.28961 & $1 \mathrm{E}-07$ & 0.00106 & $2.8 \mathrm{E}-11$ & 0 & 0.29067 & 40.61 & 313.76 & 0.30198 & $\mathrm{~L}$ \\
\hline 75 & 0.28961 & $1 \mathrm{E}-07$ & 0.00106 & $2.8 \mathrm{E}-11$ & 0 & 0.29067 & 41.14 & 314.29 & 21 & $\mathrm{~L}$ \\
\hline 76 & 0.0059 & $1.2 \mathrm{E}-25$ & 0.01745 & 4.1E-07 & 0 & 0.02335 & 40.61 & 313.76 & 0.30198 & $\mathrm{~V}$ \\
\hline 77 & 0.02335 & 0 & 0 & 0 & 0 & 0.02335 & 169.99 & 443.14 & 7.91 & $\mathrm{~L}+\mathrm{V}$ \\
\hline 78 & 0.02925 & 0 & 0.01745 & 4.1E-07 & 0 & 0.0467 & 93.77 & 366.92 & 1.01325 & V \\
\hline
\end{tabular}




\begin{tabular}{|c|c|c|c|c|c|c|c|c|c|c|}
\hline 79 & 0.0279 & 0 & 0.0004 & $1.2 \mathrm{E}-11$ & 0 & 0.0283 & 40.00 & 313.15 & 1.01325 & $\mathrm{~L}$ \\
\hline 80 & 0.00135 & 0 & 0.01706 & $4.1 \mathrm{E}-07$ & 0 & 0.0184 & 40.00 & 313.15 & 1.01325 & $\mathrm{~V}$ \\
\hline 81 & 4.39285 & $6.9 \mathrm{E}-35$ & 0.00185 & $4.9 \mathrm{E}-13$ & 0 & 4.3947 & 40.02 & 313.17 & 0.09 & $\mathrm{~L}$ \\
\hline 82 & 4.39285 & 0 & 0.00185 & $4.9 \mathrm{E}-13$ & 0 & 4.3947 & 40.21 & 313.36 & 21 & $\mathrm{~L}$ \\
\hline 83 & 0.00361 & $5.2 \mathrm{E}-35$ & 0.00079 & $3 \mathrm{E}-10$ & 0 & 0.0044 & 40.02 & 313.17 & 0.09 & $\mathrm{~V}$ \\
\hline 84 & 0.0044 & 0 & 0 & 0 & 0 & 0.0044 & 169.99 & 443.14 & 7.91 & $\mathrm{~L}+\mathrm{V}$ \\
\hline 85 & 0.00801 & 0 & 0.00079 & $3 \mathrm{E}-10$ & 0 & 0.0088 & 95.05 & 368.20 & 0.30198 & $\mathrm{~V}$ \\
\hline 86 & 0.00777 & 0 & $2.9 \mathrm{E}-05$ & $1.3 \mathrm{E}-14$ & 0 & 0.0078 & 40.00 & 313.15 & 0.30198 & $\mathrm{~L}$ \\
\hline 87 & 0.00777 & 0 & $2.9 \mathrm{E}-05$ & $1.3 \mathrm{E}-14$ & 0 & 0.0078 & 40.04 & 313.19 & 1.01325 & $\mathrm{~L}$ \\
\hline 88 & 0.03567 & 0 & 0.00042 & $1.2 \mathrm{E}-11$ & 0 & 0.03609 & 40.03 & 313.18 & 1.01325 & $\mathrm{~L}$ \\
\hline 89 & 0.00025 & 0 & 0.00076 & $3 \mathrm{E}-10$ & 0 & 0.001 & 40.00 & 313.15 & 0.30198 & $\mathrm{~V}$ \\
\hline 90 & 0.00228 & $1.4 \mathrm{E}-34$ & 0.00413 & 0.50024 & 0 & 0.50665 & 41.12 & 314.27 & 21 & $\mathrm{~V}$ \\
\hline 91 & 0 & 0 & 0 & 0.50024 & 0 & 0.50024 & 40.00 & 313.15 & 21 & $\mathrm{~V}$ \\
\hline 92 & 5.92438 & $2.1 \mathrm{E}-06$ & 0.27327 & 0.00116 & 0 & 6.19882 & 82.33 & 355.48 & 21 & $\mathrm{~L}$ \\
\hline 93 & 0.00228 & 0 & 0.00413 & 0 & 0 & 0.00641 & 40.00 & 313.15 & 21 & $\mathrm{~L}$ \\
\hline 94 & $2.9 \mathrm{E}-05$ & $7.6 \mathrm{E}-16$ & 0.00098 & 0.00051 & 0 & 0.00152 & 84.71 & 357.86 & 21 & $\mathrm{~V}$ \\
\hline MAKEUP & 0.00749 & 0.00042 & 0 & 0 & 0 & 0.00834 & 40.00 & 313.15 & 21 & $\mathrm{~L}$ \\
\hline
\end{tabular}




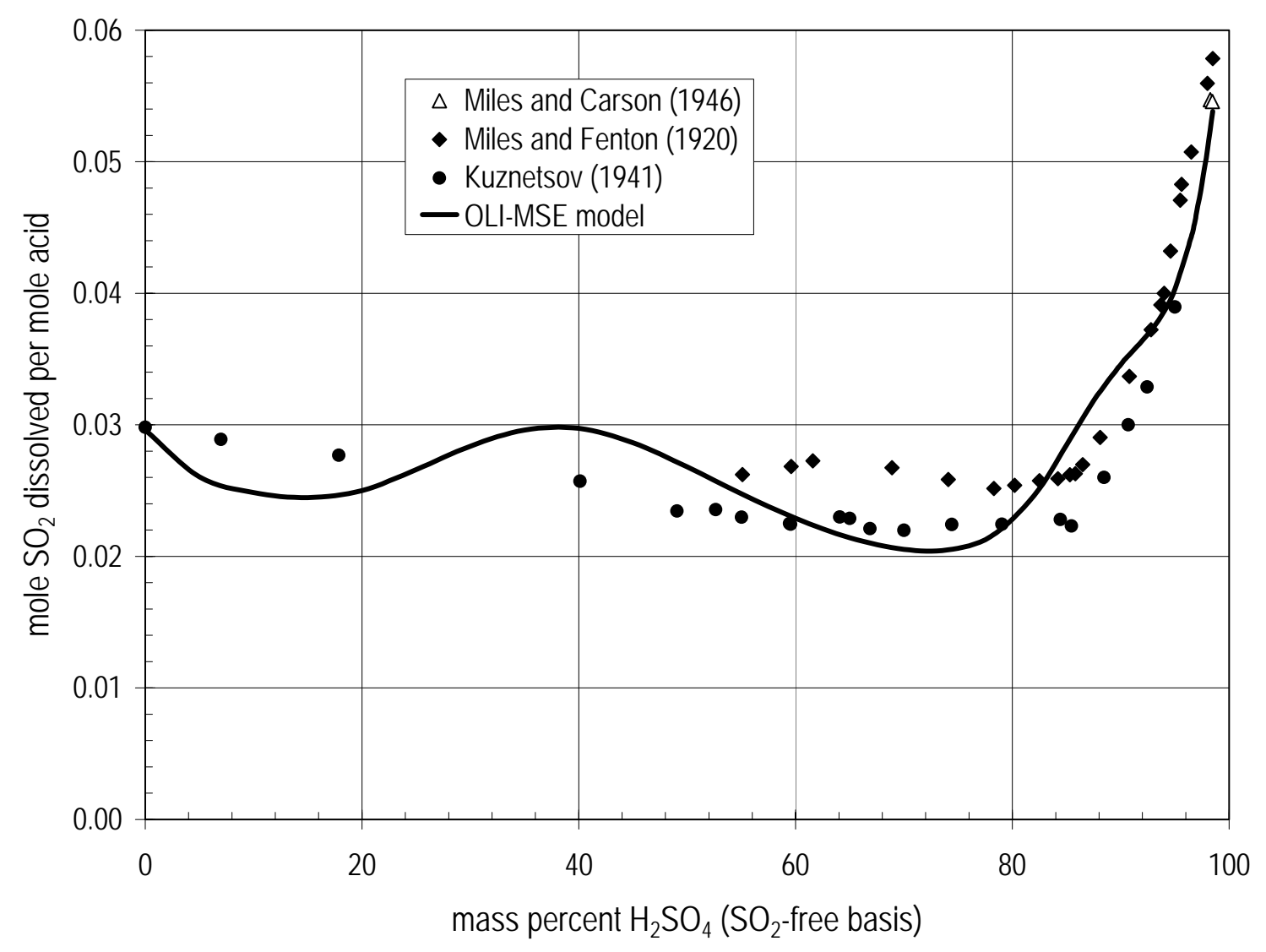

Figure 5-2 Solubility of $\mathrm{SO}_{2}$ in sulfuric acid at 1.013-bar partial pressure - comparison of OLI MSE model with data of Miles and Carson, Kuznetsov, and Miles and Fenton 


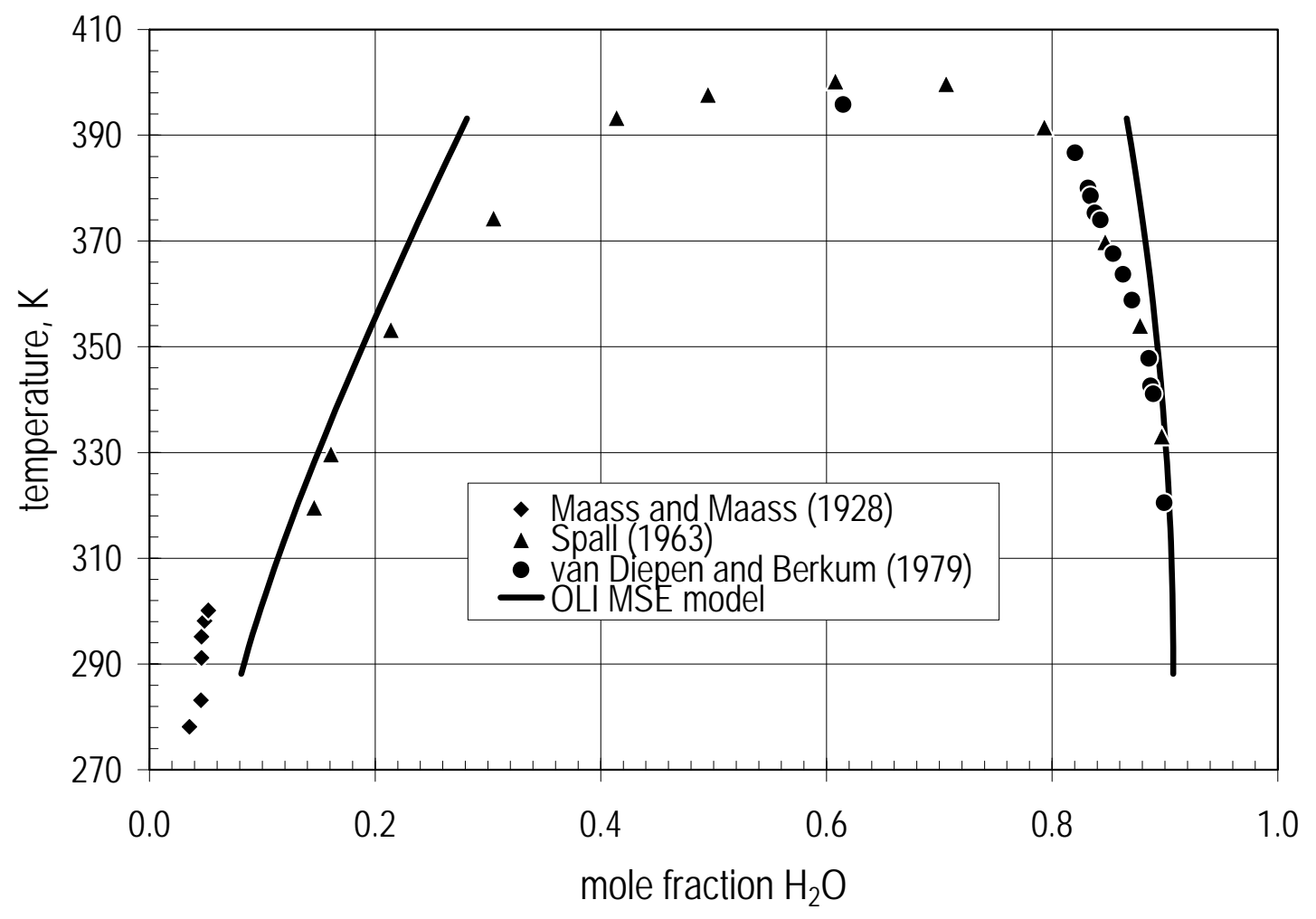

Figure 5-3 Liquid-liquid phase equilibrium in the $\mathrm{SO}_{2}-\mathrm{H}_{2} \mathrm{O}$ system - comparison of OLI MSE model with data of Maass and Maass, Spall, and van Diepen and Berkum

Returning to the flowsheet, the SDE, block EL-01, is on the left-hand side. Stream 1 is the $\mathrm{H}_{2} \mathrm{O}$ feed to the cathode side, while stream 2 is $15.5 \mathrm{wt} \% \mathrm{SO}_{2}$ dissolved in $43.5 \mathrm{wt} \% \mathrm{H}_{2} \mathrm{SO}_{4}$, fed to the anode side. Both streams are assumed to be at 21 bar pressure, and the SDE is assumed to impart a pressure drop of 1 bar due to frictional losses. The composition of stream 2 was set such that the quantity of dissolved $\mathrm{SO}_{2}$ is just below the saturation point (beyond which a separate liquid $\mathrm{SO}_{2}$ phase would form) and that the concentration of $\mathrm{H}_{2} \mathrm{SO}_{4}$ in the anolyte product following the reaction would be $50 \%$ by weight (not including $\mathrm{SO}_{2}$ ). Since a detailed model of the SDE has not yet been developed, it was treated as a "black box" in which the following changes take place:

- A net flux of $\mathrm{H}_{2} \mathrm{O}$ from the cathode to the anode (assumed to be $1 \mathrm{kmol} \mathrm{H}_{2} \mathrm{O}$ / $\mathrm{kmol} \mathrm{SO}_{2}$ reacted) is imposed. This results from the difference in water activity across the PEM.

- Reaction occurs between $\mathrm{SO}_{2}$ and $\mathrm{H}_{2} \mathrm{O}$ to make $\mathrm{H}_{2} \mathrm{SO}_{4}$ and $\mathrm{H}_{2}$ via equation (2) with an assumed $\mathrm{SO}_{2}$ conversion of $40 \%$ (i.e. the anolyte feed contains $150 \%$ excess $\mathrm{SO}_{2}$ ).

- All of the $\mathrm{H}_{2}$ product exits the cathode with the remaining water via stream 3 .

- All remaining constituents exit the anode via stream 11.

- To simulate no heat lost to the surroundings, the temperatures of streams 3 and 11 are assumed to be identical and are calculated such that the enthalpy change 
between the feed ( 1 and 2 ) and product ( 3 and 11) streams is equal to the electrical work performed with a cell potential of $0.6 \mathrm{~V}$. (This allows the heat dissipated due to the overpotential to be removed downstream.)

- Streams 3 and 11 are assumed to exit the SDE at a pressure of 20 bar.

The temperature of the $\mathrm{SDE}$ (and streams 3 and 11$)$ is maintained at $100^{\circ} \mathrm{C}(373 \mathrm{~K})$ by adjusting the temperature of anolyte feed stream 2 using heat exchanger HX-06. Experimental evidence for the diffusion of water from the cathode to the anode in a PEM SDE has been provided by Weidner and co-workers [23] at the University of South Carolina (USC). The assumed flux of $1 \mathrm{kmol} \mathrm{H}_{2} \mathrm{O} / \mathrm{kmol} \mathrm{SO}_{2}$ reacted is an estimate that needs to be refined with further experiments.

The assumed $\mathrm{SO}_{2}$ conversion of $40 \%$ is a design goal based on experimental results at SRNL and USC. Higher conversion means less material to be recycled, but at the expense of higher cell potential due to lower average $\mathrm{SO}_{2}$ concentration at the anode. Conversions in excess of $20 \%$ have been routinely achieved in SDE development experiments at SRNL, and over 50\% at USC using gaseous $\mathrm{SO}_{2}$ feed. The optimum value of conversion will be determined by a trade-off between cell potential and recycle effects once the relationship between conversion and cell potential is established.

A mixture of $\mathrm{H}_{2}$ and $\mathrm{H}_{2} \mathrm{O}$ exits the cathode side (stream 3) at $100^{\circ} \mathrm{C}(373 \mathrm{~K}$ ) and 20 bar and is cooled by interchange with stream 17 to $77^{\circ} \mathrm{C}(350 \mathrm{~K})$ in heat exchanger $\mathrm{HX}-01$, maintaining a $10^{\circ} \mathrm{C}(10 \mathrm{~K})$ minimum temperature difference. The vapor phase (stream 5) is removed in knock-out drum KO-01 and fed to the $\mathrm{H}_{2}$ Dryer (DR-01), which is cooled to $40^{\circ} \mathrm{C}(313 \mathrm{~K})$ with cooling water and is assumed to remove all of the $\mathrm{H}_{2} \mathrm{O}$ (stream 8). Pure, dry $\mathrm{H}_{2}$ is produced (stream 6$)$ at $40^{\circ} \mathrm{C}(313 \mathrm{~K})$ and 20 bar. The "feedstock" $\mathrm{H}_{2} \mathrm{O}$ that is to be split into $\mathrm{H}_{2}$ and $\mathrm{O}_{2}$ (stream 9) is combined with recycled $\mathrm{H}_{2} \mathrm{O}$ (stream 7) and that removed by the dryer (stream 8 ) and pumped back to the cathode feed by means of the cathode feed pump (PP-01). Since the flux of water across the PEM from the cathode to the anode due to diffusion is assumed to be exactly $1 \mathrm{kmol} \mathrm{H}_{2} \mathrm{O} / \mathrm{kmol} \mathrm{SO}_{2}$, this closes the water-splitting material balance.

A detailed design for the $\mathrm{H}_{2}$ Dryer was not made, and regeneration requirements were not taken into account. Simple cooling from $77^{\circ} \mathrm{C}$ to $40^{\circ} \mathrm{C}(350 \mathrm{~K}$ to $313 \mathrm{~K})$ should remove most of the water by condensation; the remainder could be absorbed by a molecular sieve. This simplification is not expected to have a significant impact on cost or energy efficiency.

The anolyte product (stream 11), containing $9.1 \mathrm{wt} \%$ unreacted $\mathrm{SO}_{2}$ dissolved in $50.1 \mathrm{wt} \%$ $\mathrm{H}_{2} \mathrm{SO}_{4}$, is split at SP-01, sending enough $\mathrm{H}_{2} \mathrm{SO}_{4}$ to decomposition via stream 12 to make all of the $\mathrm{SO}_{2}$ needed for the SDE. The remainder (representing $80 \%$ of the anolyte effluent) is recycled to the anolyte prep tank (TK-01) via stream 48 , which is first cooled to $80^{\circ} \mathrm{C}(353$ $\mathrm{K})$ by interchange with stream 17 in heat exchanger $\mathrm{HX}-05$, maintaining a $10^{\circ} \mathrm{C}(10 \mathrm{~K})$ minimum temperature difference.

The pressure of the anolyte product is dropped in three stages before being fed to the Vacuum Column (TO-01). Adiabatic throttling valve VV-01 drops the pressure to 
atmospheric, allowing over $90 \%$ of the $\mathrm{SO}_{2}$ and all but a trace of the dissolved $\mathrm{O}_{2}$ to be removed in knock-out drum $\mathrm{KO}-02$ via stream 52, along with some $\mathrm{H}_{2} \mathrm{O}$. Next, the pressure is dropped to slightly over 0.3 bar via adiabatic throttling valve VV-02. A steam-driven vacuum ejector (EJ-01) provides the suction needed to maintain vacuum. Nearly $90 \%$ of the remaining $\mathrm{SO}_{2}$ and a little more $\mathrm{H}_{2} \mathrm{O}$ are removed in knock-out drum $\mathrm{KO}-03$ via stream 69. Finally, the pressure is dropped to match the feed stage pressure in the Vacuum Column ( 0.11 bar) by means of adiabatic throttling valve $\mathrm{VV}-03$. The resulting $50.7 \% \mathrm{H}_{2} \mathrm{SO}_{4}$ stream (number 17) is heated and partially vaporized by interchange with six other streams in heat exchanger HX-02, maintaining a $10^{\circ} \mathrm{C}(10 \mathrm{~K})$ minimum temperature difference with all of them. When fed to the Vacuum Column on equilibrium stage 5, stream 18 is at $94.4^{\circ} \mathrm{C}$ $(367.6 \mathrm{~K})$ and has a vapor fraction of almost $37 \%$.

The Vacuum Column is maintained at an overhead pressure of 0.09 bar by means of the second-stage steam ejector, EJ-02. The pressure drop from bottom to top is assumed to be 0.04 bar, so the bottoms is at 0.13 bar $^{6}$. TO- 01 has 9 equilibrium stages, including a partial condenser (stage 1) and a kettle reboiler (stage 9). The reflux ratio (reflux/distillate) is 0.1 , and the distillate vapor fraction is 0.001 . A bottoms concentration of $75 \% \mathrm{H}_{2} \mathrm{SO}_{4}$ is achieved by adjusting the distillate rate (to just under $4.4 \mathrm{kmol} / \mathrm{sec}$ ). Under these conditions, the bottoms is at $122.9^{\circ} \mathrm{C}(396 \mathrm{~K})$ and requires $75.5 \mathrm{~kJ} / \mathrm{mol} \mathrm{H}_{2}$ heating, which can be supplied with a low-pressure steam utility. The overhead is at $40^{\circ} \mathrm{C}(313 \mathrm{~K})$ and requires 210.5 $\mathrm{kJ} / \mathrm{mol} \mathrm{H} \mathrm{H}_{2}$ cooling, all of which could be provided using a conventional cooling water system $^{7}$.

Bottoms product from the Vacuum Column (stream 19) is $75 \mathrm{wt} \% \mathrm{H}_{2} \mathrm{SO}_{4}$ at $122.9^{\circ} \mathrm{C}(396 \mathrm{~K})$ and 0.13 bar. It is pumped directly to the Decomposition Reactor (Bayonet Reactor, RX-01) by means of pump PP-02, which raises the pressure to 86 bar. A separate simulation (detailed in Section 3.3.4 above) was used to establish the minimum high-temperature heating target for RX-01, resulting in the requirement of $340.3 \mathrm{~kJ} / \mathrm{mol} \mathrm{H}_{2}$, which would need to be provided by the high-temperature nuclear heat source. The fractional conversion of $\mathrm{H}_{2} \mathrm{SO}_{4}$ was $48.1 \%$, and the effluent temperature was $254.7^{\circ} \mathrm{C}(528 \mathrm{~K})$ with a vapor fraction of about $20.4 \%$.

The product of the Decomposition Reactor (stream 21) is separated into its liquid (stream 22) and vapor phase (stream 31) components in knock-out drum KO-04. The pressure of the liquid product is then dropped to 21 bar by means of adiabatic throttling valve VV-04, allowing about $80 \%$ of the dissolved $\mathrm{SO}_{2}$ and $99 \%$ of the dissolved $\mathrm{O}_{2}$ to be removed in knock-out drum KO-05. The remaining liquid (stream 24) is a $59.3 \mathrm{wt} \% \mathrm{H}_{2} \mathrm{SO}_{4}$ solution at $233.4^{\circ} \mathrm{C}(507 \mathrm{~K})$ that can be recycled to the Vacuum Column. The vapor that was removed (stream 47) contains some of the $\mathrm{SO}_{2}$ and $\mathrm{O}_{2}$ products of the decomposition reaction. It is sent to the $\mathrm{SO}_{2}$ Absorber (TO-02) for separation.

\footnotetext{
${ }^{6}$ Vendor-prepared rating calculations indicate that a column pressure drop as low as 0.02 bar should be possible if FLEXERAMIC® 88 ceramic or FLEXIPAC ${ }^{\circledR}$ HC 2 Y metallic structured packing from Koch-Glitsch is used. ${ }^{7}$ This may be impossible to achieve in some climates during the summer, since it implies the cooling water supply temperature does not exceed $30^{\circ} \mathrm{C}(303 \mathrm{~K})$.
} 
The recycled, unconverted $\mathrm{H}_{2} \mathrm{SO}_{4}$ stream (number 24) is dropped in pressure before being fed to the Vacuum Column in three stages in a manner identical to the SDE anolyte product. Adiabatic throttling valve VV-05 decreases the pressure to atmospheric, allowing over $99 \%$ of the $\mathrm{SO}_{2}$ and all but a trace of the dissolved $\mathrm{O}_{2}$ to be removed in knock-out drum KO-06 via stream 54 , along with about $22 \%$ of the $\mathrm{H}_{2} \mathrm{O}$. Next, the pressure is dropped to slightly over 0.3 bar via adiabatic throttling valve VV-06. Nearly $99 \%$ of the remaining $\mathrm{SO}_{2}$ and more $\mathrm{H}_{2} \mathrm{O}$ are removed in knock-out drum KO-07 via stream 71. Finally, the pressure is dropped to match the feed stage pressure in the Vacuum Column ( 0.13 bar) by means of adiabatic throttling valve VV-07. The now $67.1 \mathrm{wt} \% \mathrm{H}_{2} \mathrm{SO}_{4}$ stream (number 29) is heated and partially vaporized by interchange with two other streams in heat exchanger HX-03, maintaining a $10^{\circ} \mathrm{C}(10 \mathrm{~K})$ minimum temperature difference with both. When fed to the Vacuum Column on equilibrium stage 8 , stream 30 is at $114.6^{\circ} \mathrm{C}(387.8 \mathrm{~K})$ and has a vapor fraction of $13.5 \%$.

Hot $\left(254.7^{\circ} \mathrm{C}, 527.8 \mathrm{~K}\right.$ ) vapor from the Decomposition Reactor (stream 31 ) is cooled to $40^{\circ} \mathrm{C}$ $(313 \mathrm{~K})$ and partially condensed in three steps (by heat exchangers HX-04A, HX-04B, and HX-04C), after which it is separated into one vapor and two liquid phases in knock-out KO08. The lighter liquid phase consists of $\mathrm{H}_{2} \mathrm{O}$ with $27.3 \mathrm{wt} \%$ dissolved $\mathrm{SO}_{2}$ and a small amount of $\mathrm{O}_{2}$. The heavier phase is liquid $\mathrm{SO}_{2}$ containing $3.7 \mathrm{wt} \% \mathrm{H}_{2} \mathrm{O}$ and a small amount of $\mathrm{O}_{2}$. HX-04A is cooled by interchange with the recycled acid feed to the Vacuum Column (HX-03), while HX-04B interchanges with the anolyte product feed to the Vacuum Column (HX-02). HX-04C rejects heat to cooling water. In practice, it would not be necessary to separate the two liquid phases in KO-08, since both are ultimately sent to the Anolyte Prep Tank. However, the split is shown to make the point that separate aqueous and $\mathrm{SO}_{2}$ phases can and do exist at these conditions.

The vapor and liquid effluents from KO-08 are let down in pressure from 86 bar to 21 bar via adiabatic throttling valves VV-08, VV-09, and VV-10, which leads to further phase changes. The vapor phases are separated from the residual liquids in knock-outs KO-09, KO-10, and $\mathrm{KO}-11$, and fed to the bottom of the $\mathrm{SO}_{2}$ Absorber, while the liquid phases are sent to the Anolyte Prep Tank.

Returning to the acid concentration part of the flowsheet, the second-stage ejector (EJ-02) effluent (stream 85) is cooled to $40^{\circ} \mathrm{C}(313 \mathrm{~K})$ with cooling water in heat exchanger HX-12 and the condensate (stream 86) pumped to waste by means of pump PP-09. This helps ensure that any contaminants that may have entered with the steam (stream 84) are purged from the system. The remaining vapors (stream 89) are sent to knock-out KO-14, which is maintained near 0.3 bar by means of the first-stage ejector, EJ-01. KO-14 also receives the partially condensed vapors from knock-outs KO-03 (stream 70) and KO-07 (stream 73), after having first been cooled with cooling water to $40^{\circ} \mathrm{C}(313 \mathrm{~K})$ by heat exchangers $\mathrm{HX}-09$ and HX-10B . Some of the heat released by condensation (in heat exchanger HX-10A) is transferred by interchange to HX-02. The aqueous phase removed by KO-14 (stream 74) is pumped to the $\mathrm{SO}_{2}$ Absorber by means of pump PP-07, where it is fed on stage 3 .

First-stage ejector (EJ-01) effluent (stream 78) is cooled to $40^{\circ} \mathrm{C}(313 \mathrm{~K})$ with cooling water in heat exchanger HX-11 and the condensate (stream 79) sent to waste. The remaining 
vapors (stream 80) are sent to an atmospheric pressure knock-out, KO-12. This knock-out also receives partially condensed vapors from knock-outs $\mathrm{KO}-02$ and $\mathrm{KO}-06$. Vapors removed in knock-out KO-02 (stream 52) are first cooled to $40^{\circ} \mathrm{C}(313 \mathrm{~K})$ with cooling water by heat exchanger HX-07, while those removed in knock-out KO-06 (stream 54) are cooled to $40^{\circ} \mathrm{C}(313 \mathrm{~K})$ in a series of three heat exchangers: HX-08A, which drops the temperature to $110.5^{\circ} \mathrm{C}(384 \mathrm{~K})$ by interchange with $\mathrm{HX}-03$; HX-008B, which further cools to $77^{\circ} \mathrm{C}(350$ $\mathrm{K}$ ) by interchange with $\mathrm{HX}-02$; and $\mathrm{HX}-08 \mathrm{C}$, which uses cooling water to achieve an outlet temperature of $40^{\circ} \mathrm{C}(313 \mathrm{~K})$.

The liquid recovered in knock-out KO-12 (stream 67) is a dilute solution of $\mathrm{SO}_{2}$ in $\mathrm{H}_{2} \mathrm{O}$ ( $4.8 \%$ by weight). It is pumped to the $\mathrm{SO}_{2}$ Absorber by means of pump PP-06, where it is fed on stage 5. The vapor removed by the knock-out (stream 58) is a moist $\mathrm{SO}_{2}$ stream (7.3 mol\% $\mathrm{H}_{2} \mathrm{O}$ ) containing about $0.3 \mathrm{~mol} \% \mathrm{O}_{2}$. It needs to be compressed to 21 bar before it can be fed to the bottom of the $\mathrm{SO}_{2}$ Absorber. This is accomplished with the three-stage $\mathrm{SO}_{2}$ Recycle Compressor, CO-01, which has intercoolers and knock-outs that cool the outlet of each stage to $40^{\circ} \mathrm{C}(313 \mathrm{~K})$ and remove any condensate.

The first stage raises the pressure to 2.78 bar. About 5\% (by volume) of the feed condenses and is removed as a $12.9 \%$ (by weight) solution of $\mathrm{SO}_{2}$ in $\mathrm{H}_{2} \mathrm{O}$ (stream 62) in the first stage intercooler and knock-out. Pump PP-04 is used to send this stream to the Anolyte Prep Tank. The second stage raises the pressure to 7.65 bar. Most of the effluent from this stage condenses in the intercooler and is removed by the knock-out (stream 64) as nearly pure liquid $\mathrm{SO}_{2}$ containing $0.8 \% \mathrm{H}_{2} \mathrm{O}$ by weight and a trace of $\mathrm{O}_{2}$. Pump PP-05 sends this stream to the Anolyte Prep Tank. Partially condensed effluent from the last stage (stream 59) is fed to knock-out KO-13. Of the original feed to CO-01 (stream 58), less than 1\% (by volume) remains in the vapor phase (stream 66) and is fed to the bottom of the $\mathrm{SO}_{2}$ Absorber; a little more than twice that amount is removed as condensate (stream 60) and sent to the Anolyte Prep Tank. Stream 66 is roughly $65 \% \mathrm{O}_{2} / 35 \% \mathrm{SO}_{2}$ (by volume), while stream 60 is $99.9 \%$ $\mathrm{SO}_{2}$ (by weight), with minor amounts of $\mathrm{O}_{2}$ and $\mathrm{H}_{2} \mathrm{O}$.

The $\mathrm{SO}_{2}$ Absorber is an eight-equilibrium stage vapor-liquid fractionation device. It operates at 21 bar pressure with an assumed negligible pressure drop. Liquid distillate from the Vacuum Column (stream 81) is fed by means of pump PP-08 to the top stage. This stream is $99.9 \% \mathrm{H}_{2} \mathrm{O}$ by weight, with $0.1 \% \mathrm{SO}_{2}$ at $40^{\circ} \mathrm{C}(313 \mathrm{~K})$. Effluent from the second-stage ejector knock-out (stream 75), containing $98.7 \% \mathrm{H}_{2} \mathrm{O}$ by weight, with $1.3 \% \mathrm{SO}_{2}$ at $41^{\circ} \mathrm{C}$ $(314 \mathrm{~K})$ is fed to stage 3 . The first-stage ejector knock-out effluent (stream 68$)$ is routed to stage 5. It contains $95.2 \% \mathrm{H}_{2} \mathrm{O}$ by weight, with $4.8 \% \mathrm{SO}_{2}$ at $40^{\circ} \mathrm{C}(313 \mathrm{~K})$. Vapor effluents from five knock-outs and the Anolyte Prep Tank vent are fed to the bottom. $\mathrm{SO}_{2}$ is scrubbed from the vapor phase as it rises up the Absorber, encountering water with progressively less dissolved $\mathrm{SO}_{2}$. The overhead product (stream 90 ) is $98.7 \% \mathrm{O}_{2}$ (by volume) at $41^{\circ} \mathrm{C}(314 \mathrm{~K}$ ) and 21 bar, with $0.5 \% \mathrm{H}_{2} \mathrm{O}$ and $0.8 \% \mathrm{SO}_{2}$. It is fed to the $\mathrm{O}_{2}$ Dryer (DR-02), where the $\mathrm{H}_{2} \mathrm{O}$ and $\mathrm{SO}_{2}$ are removed (stream 93) and routed to the Anolyte Prep Tank, leaving a pure $\mathrm{O}_{2}$ product (stream 91) at $40^{\circ} \mathrm{C}(313 \mathrm{~K})$ and 21 bar. The $\mathrm{SO}_{2}$ Absorber bottoms stream (92) contains $14.1 \%$ (by weight) $\mathrm{SO}_{2}$ in $\mathrm{H}_{2} \mathrm{O}$ at $82^{\circ} \mathrm{C}(355 \mathrm{~K})$ and 21 bar, with traces of $\mathrm{O}_{2}$ and $\mathrm{H}_{2} \mathrm{SO}_{4}$. It is sent to the Anolyte Prep Tank. 
As was true for the $\mathrm{H}_{2}$ Dryer, a detailed design for the $\mathrm{O}_{2}$ Dryer was not made, and regeneration requirements were not taken into account. Selective absorption of $\mathrm{SO}_{2}$ and $\mathrm{H}_{2} \mathrm{O}$ by a molecular sieve would be the likely mechanism. This simplification is likewise not expected to significantly impact capital cost or energy efficiency.

All of the $\mathrm{SO}_{2}$ produced by the decomposition of $\mathrm{H}_{2} \mathrm{SO}_{4}$, as well as that recovered from the SDE anolyte effluent and any liquids end up in the Anolyte Prep Tank. The resulting liquid (stream 51) is a $43.5 \% \mathrm{H}_{2} \mathrm{SO}_{4}$ solution (by weight), containing $15.5 \% \mathrm{SO}_{2}$ at a temperature of $84.7^{\circ} \mathrm{C}(358 \mathrm{~K})$ and a pressure of 21 bar. This is fed to the SDE anode after adjusting the temperature in heat exchanger HX-06 (by interchange with stream 17 via HX-02) to achieve a $100^{\circ} \mathrm{C}(373 \mathrm{~K}) \mathrm{SDE}$ outlet temperature. The anolyte feed (stream 2$)$ temperature is $78.8^{\circ} \mathrm{C}$ $(352 \mathrm{~K})$.

Make-up sulfuric acid is added to the Anolyte Prep Tank as needed to compensate for $\mathrm{SO}_{2}$ and $\mathrm{H}_{2} \mathrm{O}$ losses due to the ejector blow-downs. (More water is wasted via stream 88, which also contains some $\mathrm{SO}_{2}$, than enters with streams 77 and 84.) The quantity of make-up

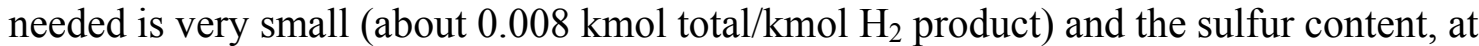
$23.6 \% \mathrm{H}_{2} \mathrm{SO}_{4}$ (by weight), corresponds to only about $0.0004 \mathrm{kmol} \mathrm{S} / \mathrm{kmol} \mathrm{H}_{2}$ product.

\subsection{FLOWSHEET ENERGY REQUIREMENTS}

Heat exchanger specifications are presented in Table 5-2. Looking at all the entries, heat input is required in only two places: the Decomposition Reactor (Bayonet Reactor, RX-01) and the Vacuum Column (TO-01) reboiler. The Decomposition Reactor is the point of transfer for high-temperature heat from the PBMR, with heat input of $340.3 \mathrm{~kJ} / \mathrm{mol} \mathrm{H}_{2}$. The reboiler, on the other hand, could use low-temperature heat, since it operates in the 100 to $125^{\circ} \mathrm{C}(373$ to $398 \mathrm{~K})$ range. The amount needed is only $75.5 \mathrm{~kJ} / \mathrm{mol} \mathrm{H}_{2}$. A grand total of $252.9 \mathrm{~kJ} / \mathrm{mol} \mathrm{H}_{2}$ waste heat is rejected to cooling water, over $80 \%$ of which occurs in the Vacuum Column condenser. Recuperation is responsible for $130.5 \mathrm{~kJ} / \mathrm{mol} \mathrm{H}_{2}$ worth of heating in $\mathrm{HX}-02$ and $31.8 \mathrm{~kJ} / \mathrm{mol} \mathrm{H}_{2}$ in $\mathrm{HX}-03$.

A small quantity of steam is also needed to drive the vacuum ejectors (streams 77 and 84 , estimated using a one-to-one molar entrainment ratio). The combined amount was calculated at about $0.0277 \mathrm{kmol} / \mathrm{sec}$, which corresponds to a $1.31-\mathrm{kJ} / \mathrm{mol} \mathrm{H}_{2}$ heat duty (from the enthalpy difference between boiler feed water at $40^{\circ} \mathrm{C}$, or $313 \mathrm{~K}$, and 7.91 -bar steam). This is two orders of magnitude smaller than the Decomposition Reactor duty, so it has little impact on the efficiency calculation. A more rigorous ejector design should be undertaken to confirm the validity of this simplification.

Electric power requirements are detailed in Table 5-3. A total of $120.9 \mathrm{~kJ} / \mathrm{mol} \mathrm{H}_{2}$ electric energy is used in the flowsheet, nearly all of it $\left(115.8 \mathrm{~kJ} / \mathrm{mol} \mathrm{H}_{2}\right)$ by the SDE. The $\mathrm{SO}_{2}$ Recycle Compressor is responsible for most of the rest, about $2.8 \mathrm{~kJ} / \mathrm{mol} \mathrm{H}_{2}$. It should be kept in mind that frictional losses due to flow through piping and equipment have been largely ignored, so the actual pumping requirement will be somewhat higher. If a thermal-to- 
electric conversion efficiency of $42 \%$ is assumed, the total electric power requirement corresponds to a heat input of $287.9 \mathrm{~kJ} / \mathrm{mol} \mathrm{H}_{2}$.

Adding together the high- and low-temperature heat requirements, the total heat supplied to the process is $417.1 \mathrm{~kJ} / \mathrm{mol} \mathrm{H}{ }_{2}$. This meets the $\leq 450 \mathrm{~kJ} / \mathrm{mol} \mathrm{H}_{2}$ goal discussed in Section 2.2. When the thermal equivalent of the power requirement is added, this flowsheet consumes a total of $705.0 \mathrm{~kJ} / \mathrm{mol} \mathrm{H}_{2}$, which compares favorably with PBMR-powered water electrolysis at $845 \mathrm{~kJ} / \mathrm{mol} \mathrm{H}_{2}$. The comparison is made more favorable if it is acknowledged that a significant portion of the heat can be supplied by another source. The $76.8 \mathrm{~kJ} / \mathrm{mol} \mathrm{H}_{2}$ heat duty needed by the Vacuum Column reboiler and the steam ejectors could be supplied by a low-pressure steam utility with a non-PBMR primary source. In that case, the quantity of PBMR heat needed by this flowsheet would be only $628 \mathrm{~kJ} / \mathrm{mol} \mathrm{H}_{2}$ (including the thermal energy needed for electricity production, as above calculated with $42 \%$ efficiency).

Table 5-2 HyS flowsheet heat exchangers

\begin{tabular}{|l|c|c|c|c|}
\hline \multirow{2}{*}{ Block ID } & \multirow{2}{*}{ Duty, $\mathrm{MW}_{\text {th }}$} & \multicolumn{2}{|c|}{ Temperature, ${ }^{\circ} \mathrm{C}(\mathrm{K})$} & \multirow{2}{*}{$\begin{array}{c}\text { Heat Exchanged } \\
\text { With: }\end{array}$} \\
\cline { 3 - 4 } & & Inlet & Outlet & Cooling Water \\
\hline CO-01/Stage 1 Cooler & -2.290 & $138.02(411.2)$ & $40.0(313)$ & Cooling Water \\
\hline CO-01/Stage 2 Cooler & -9.109 & $137.79(410.9)$ & $40.0(313)$ & Cooling Water \\
\hline DR-01 & -0.132 & $143.76(416.9)$ & $40.0(313)$ & Cooling Water \\
\hline DR-02 & -2.045 & $76.96(350.1)$ & $40.0(313)$ & Cooling Water \\
\hline HX-01 & -0.197 & $41.12(314.3)$ & $40.0(313)$ & HX-02 \\
\hline & -17.688 & $100.00(373.0)$ & $76.96(350.1)$ & HX-01, HX-04B, \\
HX-02 & & & & HX-05, HX-06, \\
& 130.486 & $66.96(340.1)$ & $94.41(367.6)$ & HX08B, HX-10A \\
\hline HX-03 & & & & HX-04A, HX-08A \\
\hline HX-04A & 31.777 & $100.50(373.7)$ & $114.62(387.8)$ & HX-03 \\
\hline HX-04B & -30.543 & $254.70(527.9)$ & $110.50(383.7)$ & HX-02 \\
\hline HX-04C & -8.400 & $110.50(383.7)$ & $76.96(350.1)$ & Cooling Water \\
\hline HX-05 & -6.243 & $76.96(350.1)$ & $40.0(313)$ & HX-02 \\
\hline HX-06 & -47.903 & $100.00(373.0)$ & $80.00(353.0)$ & HX-02 \\
\hline HX-07 & -18.686 & $84.71(357.9)$ & $78.77(351.9)$ & Cooling Water \\
\hline HX-08A & -3.702 & $84.08(357.2)$ & $40.0(313)$ & HX-03 \\
\hline HX-08B & -1.234 & $147.33(420.5)$ & $110.50(383.7)$ & HX-02 \\
\hline HX-08C & -37.440 & $110.50(383.7)$ & $76.96(350.1)$ & Cooling Water \\
\hline HX-09 & -4.021 & $76.96(350.1)$ & $40.0(313)$ & Cooling Water \\
\hline HX-10A & -1.476 & $80.38(353.5)$ & $40.0(313)$ & HX-02 \\
\hline HX-10B & -0.368 & $118.57(391.7)$ & $76.96(350.1)$ & Cooling Water \\
\hline HX-11 & -11.503 & $76.96(350.1)$ & $40.0(313)$ & Cooling Water \\
\hline HX-12 & -1.310 & $93.77(366.9)$ & $40.0(313)$ & Cooling Water \\
\hline RX-01 & -0.354 & $95.05(368.2)$ & $40.0(313)$ & High-Temp. Source \\
\hline TO-01 Reboiler & 340.280 & $123.63(396.8)$ & $254.70(527.9)$ & Cooling Water \\
\hline TO-01 Condenser & 75.482 & $102.74(375.9)$ & $122.87(396.0)$ & Low-Temp. Source \\
\hline & -210.542 & $44.80(318.0)$ & $40.0(313)$ & Heler \\
\hline
\end{tabular}


Table 5-3 HyS flowsheet electrolyzers, pumps, and compressors

\begin{tabular}{|l|c|}
\hline Block ID & Work, $\mathrm{MW}_{\mathrm{e}}$ \\
\hline EL-01 & 115.782 \\
\hline CO-01/Stage 1 & 1.464 \\
\hline CO-01/Stage 2 & 1.357 \\
\hline CO-01/Stage 3 & 0.025 \\
\hline PP-01 & 0.022 \\
\hline PP-02 & 1.836 \\
\hline PP-03 & 0.071 \\
\hline PP-04 & 0.002 \\
\hline PP-05 & 0.028 \\
\hline PP-06 & 0.055 \\
\hline PP-07 & 0.021 \\
\hline PP-08 & 0.212 \\
\hline PP-09 & 0.00003 \\
\hline
\end{tabular}

\subsection{DISCUSSION}

The flowsheet presented above and shown in Figure 5-1 combines a PEM SDE with a Decomposition Reactor, using only proven chemical process technology. If the SDE and the high-temperature decomposition reactor perform as projected $(-0.6 \mathrm{~V}$ cell potential, $40 \%$ conversion, $50 \mathrm{wt} \% \mathrm{H}_{2} \mathrm{SO}_{4}$ product; $25^{\circ} \mathrm{C}$ or $\mathrm{K}$ minimum temperature difference between $\mathrm{He}$ coolant and process stream, $10^{\circ} \mathrm{C}$ or $\mathrm{K}$ minimum temperature difference between process streams, adequate heat transfer characteristics) the flowsheet process will produce $\mathrm{H}_{2}$ and $\mathrm{O}_{2}$ from $\mathrm{H}_{2} \mathrm{O}$ while consuming $340.3 \mathrm{~kJ} / \mathrm{mol} \mathrm{H}_{2}$ high-temperature heat, $75.5 \mathrm{~kJ} / \mathrm{mol} \mathrm{H}_{2}$ lowtemperature heat, $1.31 \mathrm{~kJ} / \mathrm{mol} \mathrm{H}_{2}$ low-pressure steam, and $120.9 \mathrm{~kJ} / \mathrm{mol} \mathrm{H}_{2}$ electric power. Should the ultimate source of all of this energy be a PBMR (process heat as well as electricity at $42 \%$ conversion efficiency), the net thermal efficiency would be $40.6 \%$, HHV basis, excluding the power needed for the circulators. This is significantly more efficient than alkaline electrolysis $\left(4.8 \mathrm{kWh} / \mathrm{Nm}^{3} \mathrm{H}_{2}\right)$ or PEM electrolysis $\left(4.4 \mathrm{kWh} / \mathrm{Nm}^{3} \mathrm{H}_{2}\right)$ coupled with PBMR power (31.0\% or $33.8 \%$, HHV basis, respectively).

In reality, the efficiency difference may be even larger than it seems. PBMR electric power (at least initially) will likely be more expensive than conventional BWR/PWR power.

Passive safety constraints limit individual PBMR reactors to no more than $500 \mathrm{MW}_{\text {th }}$ in size, while the lower-temperature BWR/PWR reactors can be significantly larger $[24]^{8}$.

Economies of scale help to make the otherwise less efficient BWR/PWR power less expensive. Eventually, standardized design, factory production, and higher efficiency may overcome this limitation, but not until a number of PBMR plants have been built.

\footnotetext{
${ }^{8}$ The European Pressurized Water Reactor (EPR) under construction in Finland is rated at 4,300 $\mathrm{MW}_{\text {th }}$ and 1,600 $\mathrm{MW}_{\mathrm{e}}$ [24].
} 
Consequently, water electrolysis is initially more likely to be powered by electricity made using water-cooled reactors, which can not achieve the temperatures needed for the $\mathrm{H}_{2} \mathrm{SO}_{4}$ decomposition step in sulfur cycles. This means the net thermal efficiency (including electric power generation) for $\mathrm{H}_{2}$ production by water electrolysis will actually be approximately $26.6 \%$.

It also means that PBMRs will initially likely be used primarily for process heat, and that the HyS SDE will probably be powered by electricity from the grid. In that case, the net thermal efficiency for the HyS flowsheet process will be 36.5\% (HHV basis), assuming grid power is produced by water-cooled reactors. This compares very favorably with the $26.6 \%$ efficiency calculated for water electrolysis.

The unit cost of $\mathrm{H}_{2}$ production $\left(\$ / \mathrm{kg} \mathrm{H}_{2}\right)$ will ultimately determine whether the HyS process will be commercialized. If water can be split into $\mathrm{H}_{2}$ and $\mathrm{O}_{2}$ more economically by this method than by simple electrolysis or other competing process, then HyS plants will be the preferred choice for $\mathrm{H}_{2}$ production using nuclear power.

One additional caveat needs to be kept in mind when considering these results. Moving hot, pressurized helium through ductwork and heat exchangers requires a significant expenditure of energy. As evidenced by the results in Table 4-5, the primary and secondary loop circulators for the PBMR heat source will require on the order of $20 \mathrm{MW}_{\mathrm{e}}$ electric power. While the work performed on the helium heat transfer fluid is eventually recovered in the form of heat, the conversion loss that occurs with electric power generation imposes an additional energy penalty that should really be included in the efficiency calculation.

Finally, $252.9 \mathrm{~kJ} / \mathrm{mol} \mathrm{H}_{2}$ waste heat is rejected to cooling water. This too will require some expenditure of electric energy (to pump water to and from the cooling tower), but the amount should be much smaller than that needed for the reactor heat transfer loops.

\subsection{ASSUMPTIONS}

The flowsheet presented above relies on a series of assumptions for its predicted performance. While these have been clearly stated, a brief discussion as to their implications is in order.

Perhaps the most critical assumption is that the properties models used for flowsheet calculations accurately represent the $\mathrm{H}_{2} \mathrm{SO}_{4}-\mathrm{H}_{2} \mathrm{O}-\mathrm{SO}_{3}-\mathrm{SO}_{2}-\mathrm{O}_{2}$ system. This premise is valid for the OLI MSE $\mathrm{H}_{2} \mathrm{SO}_{4}-\mathrm{H}_{2} \mathrm{O}-\mathrm{SO}_{3}$ model [16]. The same is true for the $\mathrm{H}_{2} \mathrm{SO}_{4}-\mathrm{H}_{2} \mathrm{O}$ - $\mathrm{SO}_{3}$ properties model used in the Decomposition Reactor pinch analysis [13]. Accurate models for the solubility/miscibility of $\mathrm{SO}_{2}$ in/with mixtures of $\mathrm{H}_{2} \mathrm{SO}_{4}$ and $\mathrm{H}_{2} \mathrm{O}$, however, are still lacking. Figure 5-2 and Figure 5-3 show that while the OLI MSE model gives generally good agreement with the available data for this ternary, the fit could be much better. As for $\mathrm{O}_{2}$, little attention has been paid to its solubility in $\mathrm{H}_{2} \mathrm{SO}_{4}$ or $\mathrm{SO}_{2}$. These shortcomings, while not serious enough to have a material effect on the outcome of this work, will need to be addressed in future HyS process development efforts. 
Another crucial assumption is that heat transfer can be achieved as needed in the hightemperature Decomposition Reactor in order to achieve the specified approach temperatures. Removing heat transfer from consideration allows a pinch analysis to establish the reactor performance limit dictated by thermodynamics, i.e. determine the high-temperature heating target. This is useful in determining the bounds for reactor operating conditions and performance. Results demonstrate that the bayonet concept has the potential to decompose sulfuric acid efficiently enough for a practical HyS process. Furthermore, the selected approach temperatures are consistent with good engineering practice. A coupled heat transfer analysis still needs to be performed, however, to verify that the concept can be made to work using a hot helium heat transfer medium and with practical reactor dimensions, and to provide a design basis for a capital cost estimate.

Flowsheet calculations also assume that the high-temperature decomposition reaction proceeds to thermodynamic equilibrium. If conversion were to fall short of equilibrium, the recycle rate of unconverted acid would increase, raising the Vacuum Column reboiler duty by a small amount. The decomposition process is catalytic, so it is not unreasonable to expect that a sufficient volume of catalyst could allow the reaction to approach equilibrium. Consequently, this is not an unreasonable assumption for a bounding calculation, but the actual conversion in the Decomposition Reactor could be somewhat less than that shown.

Absent a phenomenological model of the electrolyzer, SDE operation has been characterized using development performance targets, i.e. the SDE is assumed to operate at a fixed cell potential of $-0.6 \mathrm{~V}$, with a fixed $\mathrm{SO}_{2}$ conversion of $40 \%$, and at a fixed $50-\mathrm{wt} \% \mathrm{H}_{2} \mathrm{SO}_{4}$ product composition. If these targets can not be met, the efficiency advantage of HyS over water electrolysis will be diminished. The conversion target should be the easiest to achieve, while the cell potential will likely be the hardest. An SDE unit operation model that can be incorporated into the flowsheet and that relates these cell performance measures to input parameters would help determine how much these targets can be relaxed. Such a model will need to be built for future development efforts.

The heat duties calculated for blocks HX-02 and HX-03 represent target values as determined by pinch analysis. A practical heat exchanger network for the heat recovery scheme used by these blocks (the subject of Section 5.7) needs to be designed before a capital cost can be estimated for the flowsheet.

The flowsheet ignores piping and vessel pressure drops. These will add to the actual power requirement (due to the need for pumping), but the increase should be small enough to disregard for now. Furthermore, a uniform $10^{\circ} \mathrm{C}(10 \mathrm{~K})$ minimum temperature difference for process heat exchange is assumed throughout. Optimal minimum temperature differences will vary from exchanger to exchanger, but this is a reasonable starting point for the conceptual design of a process in which energy recovery is at a premium. One significant exception was the assumption of a $25^{\circ} \mathrm{C} / \mathrm{K}$ minimum temperature difference between the process fluid in the Decomposition Reactor and the helium heating stream. 
Finally, the assumption that process streams can be cooled to $40^{\circ} \mathrm{C}(313 \mathrm{~K})$ with cooling water implies that cooling water is available year-round at $30^{\circ} \mathrm{C}(303 \mathrm{~K})$ or lower temperature. This may be somewhat geographically limiting, but it allows the Vacuum Column to be operated without a refrigerated condenser. The effect of increasing the summer cooling water temperature above $30^{\circ} \mathrm{C}(303 \mathrm{~K})$ will need to be evaluated for operation in hot climates.

\subsection{FLOWSHEET SUMMARY AND CONCLUSIONS}

The HyS cycle splits $\mathrm{H}_{2} \mathrm{O}$ into $\mathrm{H}_{2}$ and $\mathrm{O}_{2}$ by combining the high-temperature, endothermic, catalytic decomposition of $\mathrm{H}_{2} \mathrm{SO}_{4}$ into $\mathrm{H}_{2} \mathrm{O}, \mathrm{SO}_{2}$, and $\mathrm{O}_{2}$ with $\mathrm{SO}_{2}$-depolarized electrolysis that regenerates $\mathrm{H}_{2} \mathrm{SO}_{4}$. A HyS process flowsheet has been developed for use with electric power and high-temperature heat sources that combines the PEM SDE technology being developed at SRNL with Decomposition Reactor $\mathrm{H}_{2} \mathrm{SO}_{4}$ decomposition technology being developed at SNL. Conventional water electrolysis was proposed as a benchmark against which to compare this HyS cycle. If PBMR electricity is available at a $42 \%$ heat-to-power conversion efficiency, water electrolysis could be used to make $\mathrm{H}_{2}$ for a net energy consumption of perhaps as little as $845 \mathrm{~kJ} / \mathrm{mol} \mathrm{H}_{2}$. Development goals for SRNL's PEM SDE include sustained operation at a cell potential of $-0.6 \mathrm{~V}$, which was shown to be equivalent to a $276-\mathrm{kJ} / \mathrm{mol} \mathrm{H} \mathrm{H}_{2}$ primary energy source. This leaves a margin of $845 \mathrm{~kJ}-276$ $\mathrm{kJ}=569 \mathrm{~kJ}$ heat per mol $\mathrm{H}_{2}$ product for the $\mathrm{H}_{2} \mathrm{SO}_{4}$ decomposition step in order to match the water electrolysis efficiency. A goal of $\leq 450 \mathrm{~kJ} / \mathrm{mol} \mathrm{H}_{2}$ was established to provide an edge.

A pinch analysis was used to establish high-temperature heating targets for the decomposition reactor as a function of pressure and $\mathrm{H}_{2} \mathrm{SO}_{4}$ feed concentration. Results of the analysis showed that heating targets were below $450 \mathrm{~kJ} / \mathrm{mol} \mathrm{SO}_{2}$ for feed concentration $\geq 60$ $\mathrm{wt} \%$ and that increasing pressure decreases the target. This requires that the SDE product with its maximum concentration of $50 \mathrm{wt} \%$ be concentrated before being fed to the Decomposition Reactor to meet the high-temperature heat requirement goal.

Vacuum distillation with recuperative preheating/partial vaporization of the feed streams and using a two-stage steam ejector was chosen to concentrate the SDE product. Temperatures could be kept high enough to allow use of cooling water in the condenser, yet low enough to allow metallic materials of construction. Only proven process technology was utilized, leaving the SDE and the Decomposition Reactor as the only major components that need development.

The resulting flowsheet, illustrated in Figure 5-1, and with stream and equipment performance data tabulated in Table 5-1, Table 5-2, and Table 5-3, requires $340.3 \mathrm{~kJ} / \mathrm{mol} \mathrm{H}_{2}$ high-temperature heat, $75.5 \mathrm{~kJ} / \mathrm{mol} \mathrm{H}_{2}$ low-temperature heat, $1.31 \mathrm{~kJ} / \mathrm{mol} \mathrm{H}_{2}$ low-pressure steam, and $120.9 \mathrm{~kJ} / \mathrm{mol} \mathrm{H}_{2}$ electric power. (If a $42 \%$ heat-to-power conversion efficiency is assumed, the electric power corresponds to a primary energy input of $287.9 \mathrm{~kJ} / \mathrm{mol} \mathrm{H}_{2}$.) Adding together the heat requirements and the thermal equivalent of the power requirement, it consumes a total of $705.0 \mathrm{~kJ} / \mathrm{mol} \mathrm{H}_{2}$, which compares favorably with PBMR-powered electrolysis at $845 \mathrm{~kJ} / \mathrm{mol} \mathrm{H}_{2}$. When conventional nuclear reactors are assumed to be the 
source of electric power, the PBMR-heated HyS process has an even larger advantage over water electrolysis $\left(783 \mathrm{~kJ} / \mathrm{mol} \mathrm{H}_{2}\right.$ versus $1,076 \mathrm{~kJ} / \mathrm{mol} \mathrm{H}_{2}$, respectively).

\subsection{ENERGY INTEGRATION STUDY}

This study was completed as part of the conceptual study for the HyS Process to evaluate the potential for heat integration and recovery. The study was completed using data provided by SRNL and Westinghouse Electric Co. which was included both in the preliminary flow diagram and in the output from the Aspen Plus model run.

The Mixer block Q-HX-02 in the Aspen Plus simulation clearly performed a heat balance, but not a proper heat integration. Of the six streams used to heat stream 17/18, which has a cold end temperature of $67^{\circ} \mathrm{C}$, four of them have a cold end temperature of $77^{\circ} \mathrm{C}$. If we assume a minimum cold end approach of $10^{\circ} \mathrm{C}$, only one of these streams can be fully cooled with stream 17/18. One of these, from HX-10A (stream 71/72), has a very small duty and can be cooled without appreciably raising the temperature of stream 17/18. The next

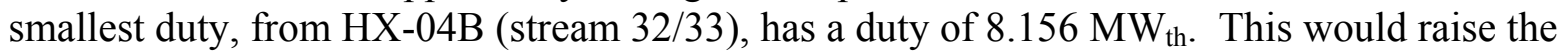
cold stream temperature about $1.6^{\circ} \mathrm{C}$. The next largest stream has a duty of $14.936 \mathrm{MW}_{\text {th }}$, which represents a $3^{\circ} \mathrm{C}$ rise in the cold stream. By the time we get to the third stream, the cold end approach is already down to $<5.4^{\circ} \mathrm{C}$. We, therefore, set out to develop a preliminary, and admittedly conservative, heat integration study.

The methodology used in the study was to evaluate the quality of the heat sources created in the process and to match them with the required heating load. Heat sources were evaluated by enthalpy and temperature based on a temperature approach of $10^{\circ} \mathrm{C}$. The order of the high enthalpy streams was selected to optimize the efficiency of the heat recovery.

Where the enthalpy of the streams was not used directly for heat recovery these streams were cooled with water to the required temperature. For the study the cooling water temperatures used were $30^{\circ} \mathrm{C}$ for cooling water supply and $35^{\circ} \mathrm{C}$ for the cooling water return temperature.

Medium pressure (MP) Steam at 7.91 bar has been used in the study as supplementary heating for both the acid feed streams to the Decomposition Reactor, the vacuum stripper reboiler and for the steam ejectors.

The enthalpy/temperature diagrams in Appendix 10.0 (Figure 10-1, Figure 10-2, and Figure 10-3) illustrate the proposed heat recovery system and show which streams were used. For this work the heat balance is based on HyS Process Energy Balance -Case 1R (1 kmol/s $\mathrm{H}_{2}$ ).

Table 10-1 in Appendix 10.0 provides a summary of the exchangers used in the process proposed by SRNL/Westinghouse. This table also summarizes the energy balance for the proposed process. The energy input for the two ejectors and the power input of the rotating equipment are included in the overall numbers, but the study does not include the energy input for the electrolytic cells or for the Decomposition Reactor. 
The following results were taken directly from Table 10-1.

$\begin{array}{ll}\text { Total Cooling Load } & 414.6 \mathrm{MW}_{\text {th }} \\ \text { Cooling Provided by Heat Interchange } & 136.3 \mathrm{MW}_{\text {th }} \\ \text { Cooling Water Load } & 278.4 \mathrm{MW}_{\text {th }} \\ & \\ & 257.0 \mathrm{MW}_{\text {th }} \\ \text { Total Heating Load } & 136.3 \mathrm{MW}_{\text {th }} \\ \text { Heating provided by Cooling Interchange } & 120.8 \mathrm{MW}_{\text {th }}\end{array}$

Table 10-1 also shows the data used, the proposed materials of construction and the resulting size of the exchangers. Equipment sizing for the project is based on the HyS Process Energy Balance - Case 1 (1 PBMR module).

Further optimization of the heat integration scheme will be required later in the design process. 


\subsection{PLANT CONCEPTUAL DESIGN AND COST ESTIMATE}

This section presents the conceptual design and cost estimate for a single module PBMR reactor combined with the HyS Process based on the updated flowsheet described in Section 5.0 of this report.

\subsection{REFERENCE DESIGN PERFORMANCE SUMMARY}

The Reference Design performance conditions are a result of the selection of the PBMR operating conditions, the nuclear/hydrogen plant interface, and the Hybrid Sulfur flowsheet and energy balance. Each area is summarized in the following subsections.

\subsubsection{PBMR-NHSS Reference Design Summary}

The effects of various PBMR operating conditions and interface scenarios were analyzed as discussed in Section 4.0 of this report. As stated in Section 4.5, Case 1 was selected as the Reference Design. The operating parameters are summarized in Table 6-1.

\subsubsection{Hybrid Sulfur Process Performance Summary}

The hydrogen output and plant efficiency is also determined by the design and energy requirements of the Hybrid Sulfur hydrogen production system. The HyS flowsheet and energy balance was presented and discussed in Section 5.0. The energy performance of the HyS process is summarized in Table 6-2. 
Table 6-1 Reference Design for PBMR-NHSS (Case 1)

\begin{tabular}{|c|c|}
\hline PBMR power level, $\mathrm{MW}_{\text {th }}$ & 500 \\
\hline Hydrogen production rate, $\mathrm{kmol} / \mathrm{hr}$ & 3309 \\
\hline Hydrogen production rate, MT/day & 160.1 \\
\hline \multicolumn{2}{|l|}{ Primary Helium Conditions } \\
\hline He flow rate, $\mathrm{kg} / \mathrm{s}$ & 159.5 \\
\hline He flow rate at reactor outlet, $\mathrm{m}^{3} / \mathrm{s}$ & 47.3 \\
\hline Pressure, circulator outlet, $\mathrm{MPa}$ & 9.0 \\
\hline Temperature, PBMR inlet, ${ }^{\circ} \mathrm{C}$ & 350 \\
\hline Temperature, PBMR outlet, ${ }^{\circ} \mathrm{C}$ & 950 \\
\hline \multicolumn{2}{|l|}{ Secondary Helium Temperatures, ${ }^{\circ} \mathrm{C}$} \\
\hline He flow rate, $\mathrm{kg} / \mathrm{s}$ & 159.5 \\
\hline Pressure, circulator outlet, $\mathrm{MPa}$ & 9.3 \\
\hline Temperature, IHX inlet, ${ }^{\circ} \mathrm{C}$ & 286.9 \\
\hline Temperature, IHX outlet, ${ }^{\circ} \mathrm{C}$ & 900 \\
\hline Temperature, $\mathrm{PCHX}$ inlet, ${ }^{\circ} \mathrm{C}$ & 900 \\
\hline Temperature, $\mathrm{PCHX}$ outlet, ${ }^{\circ} \mathrm{C}$ & 522.7 \\
\hline \multicolumn{2}{|l|}{ Acid Decomposer Conditions } \\
\hline Pressure, $\mathrm{MPa}$ & 8.6 \\
\hline Peak temperature, ${ }^{\circ} \mathrm{C}$ & 870 \\
\hline PCHX heat duty, $\mathrm{MW}_{\text {th }}$ & 312.8 \\
\hline \multicolumn{2}{|l|}{ Other Major Components } \\
\hline Steam Generator heat duty, $\mathrm{MW}_{\text {th }}$ & 203.5 \\
\hline Primary Circulator power, $\mathrm{MW}_{\mathrm{e}}$ & 11.6 \\
\hline Secondary Circulator power, $\mathrm{MW}_{\mathrm{e}}$ & 8.7 \\
\hline
\end{tabular}

Table 6-2 Hybrid Sulfur Process Energy Balance

\begin{tabular}{|l|r|}
\hline SDE Design Conditions & \\
\hline Temperature, ${ }^{\circ} \mathrm{C}$ & 100 \\
\hline Pressure, bar & 20 \\
\hline Acid concentration, $\mathrm{wt}^{\circ} \mathrm{H}_{2} \mathrm{SO}_{4}$ & 50 \\
\hline $\mathrm{SO}_{2}$ conversion, $\%$ & 40 \\
\hline Average cell potential, $\mathrm{mV}$ & 600 \\
\hline Decomposition Reactor Conditions & \\
\hline Reactor type & Bayonet \\
\hline Reactor pressure, bar & 86 \\
\hline Peak process temperature, ${ }^{\circ} \mathrm{C}$ & 870 \\
\hline Acid feed concentration, $\mathrm{wt} \% \mathrm{H}_{2} \mathrm{SO}_{4}$ & 75 \\
\hline $\mathrm{H}_{2} \mathrm{SO}{ }_{4}$ conversion, $\%$ & 48.1 \\
\hline HyS Energy Requirements & 115.8 \\
\hline Electrolyzer, $\mathrm{kJ} / \mathrm{mol}(\mathrm{elec})$ & 5.1 \\
\hline Pumps, compressors, $\mathrm{misc} ., \mathrm{kJ} / \mathrm{mol}(\mathrm{elec})$ & 340.3 \\
\hline Decomposition reactor, $\mathrm{kJ} / \mathrm{mol}$ & 76.8 \\
\hline Acid concentration, $\mathrm{kJ} / \mathrm{mol}$ & \\
\hline
\end{tabular}




\subsubsection{Overall Reference Design Performance Summary}

The overall nuclear hydrogen plant performance summary is shown in Table 6-3. The performance is based on a single 500-MWth PBMR. It is assumed that all excess heat in the secondary helium loop that cannot be used by the decomposition reactor or the acid concentration system is used to generate electricity. The heat-to-electric generating efficiency is assumed to be $41.2 \%$. Electricity demand in excess of the onsite generation is assumed to be provided by the grid. For efficiency calculation purposes, it is also assumed to be generated at a net heat-to-electric efficiency of $41.2 \%$. The HyS electrolyzer power supply rectifier is assumed to have an efficiency of $96 \%$.

Table 6-3 Reference Design Performance Summary

\begin{tabular}{|c|c|}
\hline PBMR Power Rating, MW $_{\text {th }}$ & 500 \\
\hline \multicolumn{2}{|l|}{ Hydrogen Output } \\
\hline Mass flow rate, $\mathrm{MT} /$ day & 160.1 \\
\hline Thermal value (HHV), $\mathrm{MW}_{\text {th }}$ & 262.8 \\
\hline \multicolumn{2}{|l|}{ Thermal Energy Requirements, $\mathbf{M W}_{\mathrm{th}}$} \\
\hline High-temperature heat to Decomposition & 312.8 \\
\hline Steam to acid concentration & 70.6 \\
\hline Steam for power generation & 132.9 \\
\hline \multicolumn{2}{|l|}{ Electric Power Requirements, $\mathrm{MW}_{\mathrm{e}}$} \\
\hline Helium circulators & 20.3 \\
\hline HyS electrolyzer power supply (AC) & 110.8 \\
\hline HyS pumps, circulators, etc. & 4.7 \\
\hline NHSS, PGS and BOP ${ }^{1}$ & 8.2 \\
\hline Total electric demand & 144.0 \\
\hline Onsite power generation & 54.8 \\
\hline Net electric power from grid & 89.2 \\
\hline \multicolumn{2}{|l|}{ Overall Plant Efficiency } \\
\hline Reactor thermal input, $\mathrm{MW}_{\text {th }}$ & 500.0 \\
\hline Thermal equivalent of import electricity, ${ }^{2} \mathrm{MW}_{\text {th }}$ & 216.5 \\
\hline Total thermal input, $\mathrm{MW}_{\mathrm{th}}$ & 716.5 \\
\hline Overall plant efficiency (HHV basis) & 36.7 \\
\hline
\end{tabular}

Notes:

${ }^{1} \mathrm{NHSS}=5.6 \mathrm{MW}_{\mathrm{e}}$; PGS = 1.2 $\mathrm{MW}_{\mathrm{e}}$; BOP $=1.4 \mathrm{MW}_{\mathrm{e}}$. Based on "NGNP and Hydrogen Production Preconceptual Design Report, NGNP-08-RPT-00”, Westinghouse Electric Company, May 2007, Table 8-17.

2 Assumes $41.2 \%$ thermal-to-electric conversion efficiency 


\subsection{EQUIPMENT SELECTION AND SIZING AND MATERIALS OF CONSTRUCTION}

\subsubsection{Equipment Selection and Sizing}

The HyS plant components were selected and sized in detail on the basis of the process flowsheet and the physical properties of the process streams. The available output data was suitably modified to get input for the component sizing process. Only commercially existing equipment were chosen. The selections were suitably adapted to the actual working conditions. Traditional engineering procedures were used to size in detail all the equipment of the HyS plant, reaching the best possible design, from an economic point of view. The major equipment lists showing equipment type, physical size, mechanical design conditions and materials of construction are given in Appendix 11.0. Shell and tube heat exchangers have been selected as heat transfer devices. They were sized in detail, following standard TEMA classification, rules and suggestions and varying the most important parameters and degrees of freedom (e.g. tube diameters, tube length, baffle typology and arrangement, etc.) to get to the best solution. Knock-out pots, flash drums, etc have been sized adopting traditional methodologies choosing vertical or horizontal equipment depending on the specific working conditions. Pumping equipment (centrifugal pumps or rotary pumps, along with diaphragm pumps, have been adopted) were sized choosing the most suitable pump models accounting for flow rates and head to be supplied. A three-stage centrifugal compressor was adopted to recycle $\mathrm{SO}_{2}$ in the $\mathrm{H}_{2} \mathrm{SO}_{4}$ decomposition section, internally recovering (in the $\mathrm{H}_{2} \mathrm{SO}_{4}$ section) the heat available from the inter-cooling process. The vacuum $\mathrm{H}_{2} \mathrm{SO}_{4}$ concentration column and the $\mathrm{SO}_{2}$ absorber were sized as packed towers considering traditional sizing methods.

\subsubsection{Materials of Construction}

The choice of materials of construction for the equipment represents a fundamental aspect of the overall problem, which can lead to wide variations of the whole investment cost of the HyS plant. All the components (with the exception of the SDE and the $\mathrm{H}_{2} \mathrm{SO}_{4}$ decomposition reactor, whose designs are described in detail in other sections) have been sized considering only well-known, traditional metal materials capable of resisting the actual working conditions. A material selection summary based on stream analyses is given in Appendix 12.0 .

Regarding the product purification section of the plant, almost all of the equipment is made of carbon steel (CS) material. Likewise, components of the feed and utility supply section, which are in contact with water, have been assumed to be made of CS material.

As for the other parts of the plant, where sulfur compounds and hydrogen (and water) circulate, various corrosion-resistant materials have been chosen. 316L Stainless Steel (SS) has been adopted as the baseline material, due to its capability to resist aggressive conditions, such as contact with $\mathrm{H}_{2} \mathrm{SO}_{4}$ over wide concentration ranges. To resist more difficult environments (in terms of concentrations and operating temperatures) which would attack 316L SS type materials, stainless steel $20 \mathrm{Cb} 3$ and, where appropriate, Hastelloy B3 have 
been adopted. $20 \mathrm{Cb} 3$ is an austenitic SS with good resistance to concentrated $\mathrm{H}_{2} \mathrm{SO}_{4}$ at high temperatures. Hastelloy B3 is a nickel-based alloy which shows good resistance to $\mathrm{H}_{2} \mathrm{SO}_{4}$ mixtures over a broad range of temperatures and concentrations, with high thermal stability and resistance to pitting corrosion and stress corrosion. $20 \mathrm{Cb} 3$ and Alloy B3 materials have been adopted inside the $\mathrm{H}_{2} \mathrm{SO}_{4}$ section for the most aggressive environments.

The $\mathrm{H}_{2} \mathrm{SO}_{4}$ concentration process equipment is made of $20 \mathrm{Cb} 3$ and Alloy B3 materials. In particular the shell of the $\mathrm{H}_{2} \mathrm{SO}_{4}$ vacuum column (with ceramic packing internals) has been assumed to be made of CS material, with Hastelloy B3 internal cladding. The two concentration flashes are made of $20 \mathrm{Cb} 3$ and Alloy B3 (for higher temperatures and concentrations) and the $\mathrm{H}_{2} \mathrm{SO}_{4}$ decomposer feed pump has been assumed to be made of Alloy B3. Likewise, the two flashes, operating at temperatures of $255^{\circ} \mathrm{C}(528 \mathrm{~K})$ and $234^{\circ} \mathrm{C}(507$ K) respectively, which separate unreacted $\mathrm{H}_{2} \mathrm{SO}_{4}$ from the other compounds $\left(\mathrm{SO}_{2}, \mathrm{H}_{2} \mathrm{O}\right.$ and $\mathrm{O}_{2}$ ) exiting the bayonet reactor, are made of Hastelloy B3. The remainder of the equipment (i.e. $\mathrm{SO}_{2}$ separation, $\mathrm{SO}_{2}$ recirculation, etc.) has been assumed to be made of $316 \mathrm{~L} \mathrm{SS}$. Particularly aggressive conditions exist in the balance of the electrolysis section equipment, which led to the adoption of $20 \mathrm{Cb} 3$ and Hastelloy B3 as the materials of construction for both heat exchangers and recirculation pumps.

\subsection{COMMERCIAL ELECTROLYZER DESIGN AND COST}

\subsubsection{General Description}

The SDE consists of a stack of electrochemical cells configured in a bipolar arrangement utilizing PEM electrolytes. Sulfuric acid containing dissolved $\mathrm{SO}_{2}$ is passed thru the anodeside of each cell and hydrogen gas is evolved on the cathode-side. Each individual cell consists of an MEA held between two porous carbon gas diffusion layers. Non-porous graphite bipolar plates separate cells from each other and provide flow fields for both the acid and the hydrogen. Up to 200 cells are connected in series and constrained between steel end plates using tie-rods. Gaskets between cells provide sealing for operating pressures up to 300 psia.

\subsubsection{Design Requirements and Specifications}

A PBMR hydrogen plant will require multiple modules of cells. The design requirements and specifications for an individual electrolyzer module are shown in Table 6-4. 
Table 6-4 SDE Module Specifications

\begin{tabular}{|l|l|l|}
\hline PROPERTY & UNITS & VALUE \\
\hline & & \\
\hline Single cell size (active area) & $\mathrm{m}^{2}$ & 1.0 \\
\hline No. of cells per module & -- & 200 \\
\hline Avg. voltage per cell & $\mathrm{mV}$ & 600 \\
\hline Current density & $\mathrm{mA} / \mathrm{cm}^{2}$ & 500 \\
\hline Cell operating temperature (outlet) & ${ }^{\circ} \mathrm{C}$ & 100 \\
\hline Cell operating pressure & $\mathrm{bar}$ & 20 \\
\hline $\mathrm{SO}_{2}$ utilization & $\%$ & 40 \\
\hline Anode $\mathrm{H}_{2} \mathrm{SO}_{4}$ concentration (outlet) & $\mathrm{Wt} \%$ & 50 \\
\hline Anolyte flow rate (inlet) & $\mathrm{kg} / \mathrm{hr}$ & 322.3 \\
\hline Catholyte water flow rate (inlet) & $\mathrm{kg} / \mathrm{hr}$ & 56.0 \\
\hline Module voltage & $\mathrm{V}(\mathrm{DC})$ & 120 \\
\hline Module current & $\mathrm{A}$ & 5000 \\
\hline DC power input & $\mathrm{kW}$ & 600 \\
\hline Hydrogen output (flow rate) & $\mathrm{kg} / \mathrm{hr}$ & 37.62 \\
\hline Hydrogen output (HHV) & $\mathrm{MW}$ th & 1.5 \\
\hline
\end{tabular}

\subsubsection{Module Conceptual Design}

In order to contain the required 20 bar (300 psia) pressure, a circular bipolar plate cell design is adopted. Each cell has an active area of $1.0 \mathrm{~m}^{2}$. The bipolar plates have an outer diameter of $1.22 \mathrm{~m}$ (48 in). The total thickness of each cell is $0.5 \mathrm{in}$; the overall length of the 200 -cell stack is $2.54 \mathrm{~m}$ (100 in). The overall length of a module, including the end plates and other structural components, is $3.15 \mathrm{~m}$ (124 in). A drawing of a single module is shown in Figure 6-1. (NOTE: A photograph of a Norsk Hydro high pressure electrolyzer is shown for reference. The SDE module drawing is in progress).

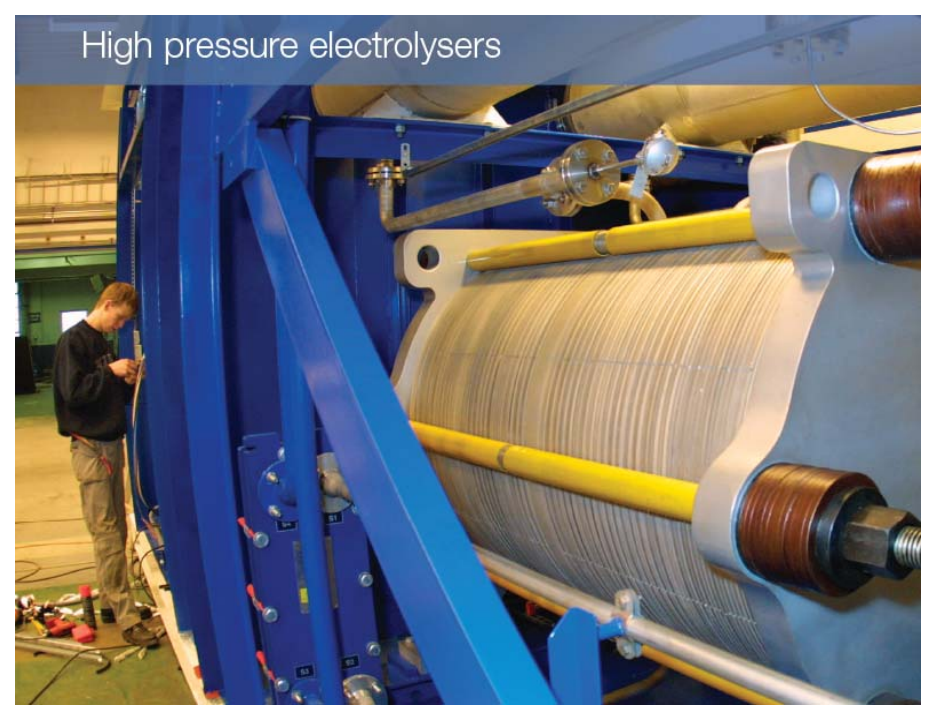

Figure 6-1 200-cell SDE Module 


\subsubsection{Electrolyzer Plant Arrangement}

The total hydrogen output for a PBMR-HyS nuclear hydrogen plant (Reference Design Case 1) is $3,309 \mathrm{kmol} / \mathrm{hr}$, or $160.1 \mathrm{MT} /$ day. Each 200 -cell module has a hydrogen output capacity of $37.62 \mathrm{~kg} / \mathrm{hr}$, or $0.903 \mathrm{MT} /$ day. Therefore, a plant operating at full capacity will require 160.1/0.903 or 177 modules. Additional modules will be needed to provide a $5-10 \%$ capacity margin to provide for maintenance, performance losses, etc. Therefore, the total

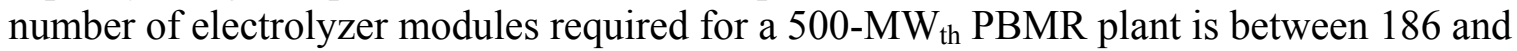
195. The selected arrangement consists of four cell rooms or buildings, with 48 modules per cell room. The total number of SDE modules is 192. The arrangement of a cell room is shown in Figure 6-2.

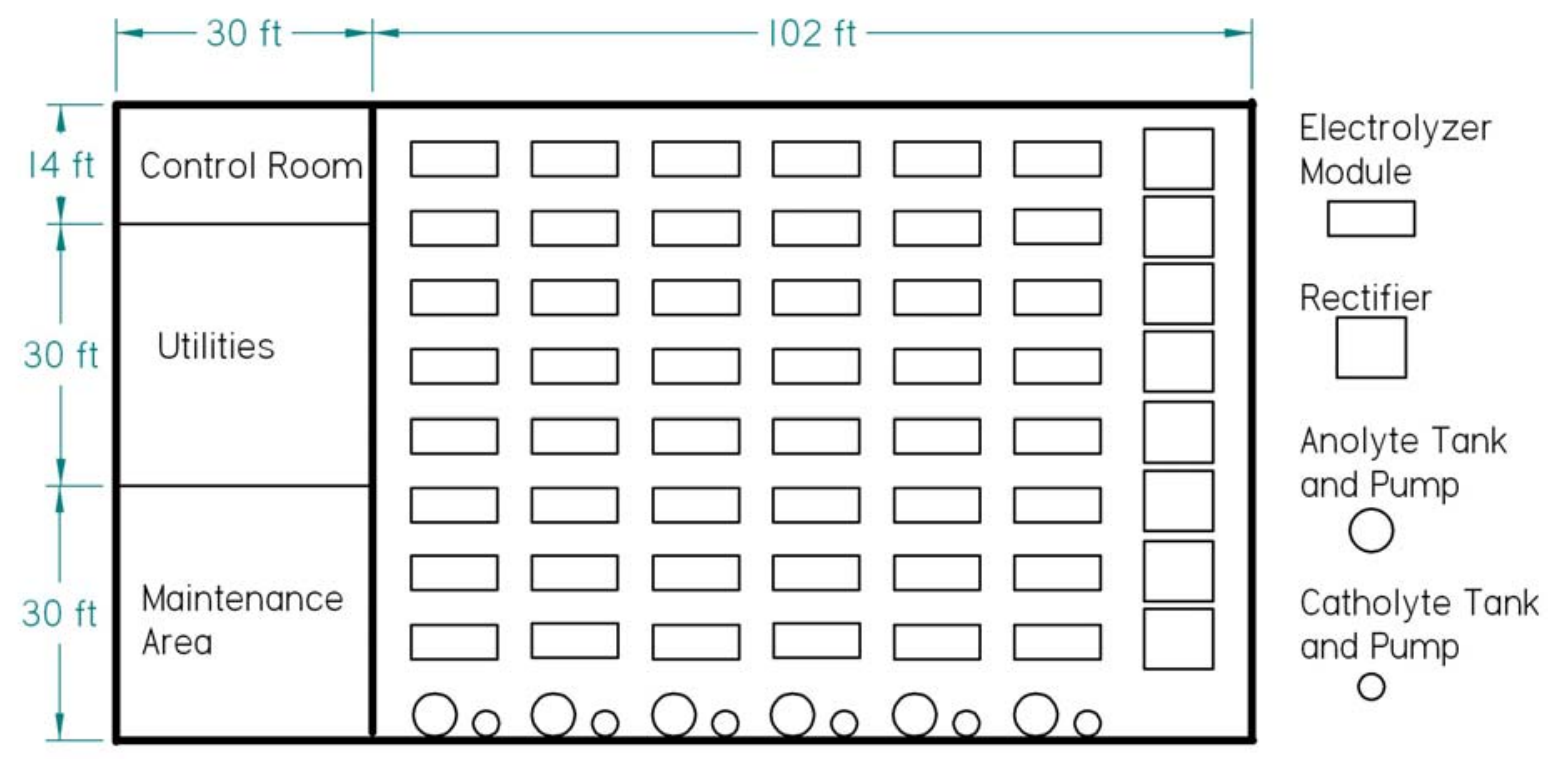

Electrlyzer Array I of 4

Figure 6-2 48-module Cell Room Arrangement

\subsubsection{Capital Cost Estimate}

The capital cost of a module consists of the repeating cost for each cell and the cost of the module structural, electrical and piping systems.

\subsubsection{Cell Capital Cost Estimate}

The cost of each of the 200 individual electrolyzer cells is shown in Table 6-5. 
Table 6-5 Cell Capital Costs

\begin{tabular}{|c|c|c|c|}
\hline Item & Description & Cost Basis & $\$ / \mathbf{m}^{2}$ \\
\hline Membrane & Nafion ${ }^{\circledR} 117$ or equiv & $\$ 300 / \mathrm{m}^{2}$ & 300 \\
\hline Gas diffusion layers & Porous carbon & $\$ 75 / \mathrm{m}^{2}$ (2 layers req'd) & 150 \\
\hline Electrocatalyst & $1 \mathrm{mg} / \mathrm{cm}^{2} \mathrm{Pt}$ (total) & $\$ 1500 /$ troy oz & 480 \\
\hline Bipolar plates & 3/8-in graphite & $\$ 200 / \mathrm{m}^{2}$ & 200 \\
\hline Seals, gaskets, etc. & PEEK or equiv & $50 / \mathrm{m}^{2}$ & 50 \\
\hline Cell assembly & Automated & 1 man-hr@\$50/man-hr & 50 \\
\hline \multicolumn{3}{|l|}{ Single cell cost } & 1,230 \\
\hline
\end{tabular}

\subsubsection{SDE Module Capital Cost Estimate}

An SDE module consists of 200 cells, two end plates, tie rods and other structural components, current collectors, connections to DC bus, supply lines and headers for cells, piping connections to main piping, structural support for module, local instrumentation, and miscellaneous equipment. It is assumed that each module is moved into place using an overhead crane. The module cost estimate is shown in Table 6-6. Each module contains 200 cells with a total active cell area of $200 \mathrm{~m}^{2}$.

Based on the costs given in Table 6-6 the capital cost of a single SDE module, including module assembly and delivery, is $\$ 1,368$ per $\mathrm{m} 2$, or $\$ 273,600$ per module. A commercial HyS Process Plant for a single $500 \mathrm{MW}_{\text {th }}$ PBMR requires 192 modules, including spares as discussed in Section 6.3.4 above. The total cost of 192 modules is $\$ 52.5$ million 
Table 6-6 SDE Module Capital Costs

\begin{tabular}{|l|l|l|l|}
\hline \multicolumn{1}{|c|}{ Item } & \multicolumn{1}{|c|}{ Description } & \multicolumn{1}{c|}{ Cost Basis } & \multicolumn{1}{c|}{$\$ / \mathbf{m}^{2}$} \\
\hline Individual cells & 200 units & $\begin{array}{l}\text { Table 6-5 less 20\% for } \\
\text { NOAK improvements }\end{array}$ & 984 \\
\hline $\begin{array}{l}\text { End plates, tie rods, \& } \\
\text { other pressure comp. }\end{array}$ & Carbon steel & $\$ 20,000$ total & 100 \\
\hline $\begin{array}{l}\text { Current collectors \& } \\
\text { connection to DC bus }\end{array}$ & Copper & $\$ 8,000$ total & 40 \\
\hline Supply lines to cells & 4 lines; every 10 cells & $\$ 100$ per line x 80 & N/A \\
\hline Other piping connect. & & $\$ 4,000$ & N/A \\
\hline Instruments and misc. & & $\$ 2,000$ & N/A \\
\hline Module supports & Weight $=8$ t & $\$ 10,000$ total & N/A \\
\hline Module assembly & Off-site assembly & 64 man-hr @ $\$ 50 /$ man-hr & 16 \\
\hline Module installation & & 64 man-hr @ \$50/man-hr & N/A \\
\hline Subtotal & & & 1,140 \\
\hline Overhead & Electrolyzer mfg. & $20 \%$ of matls \& labor & 228 \\
\hline & & & 1,368 \\
\hline Total SDE Module & & & \\
\hline
\end{tabular}

\subsubsection{Items Not Included}

The following items are not included in the SDE Module cost estimate. These items are part of the overall Electrolyzer Section of the HyS Process Plant and should be estimated separately.

- Cell room buildings (4 required)

- Main process piping system

0 anolyte feed

- anolyte return

- cathode water supply

- cathode $/ \mathrm{H}_{2}$ from cell

- $\mathrm{H}_{2}$ product

- Anolyte processing equipment (KO drum, HX, etc.)

- Anolyte main pumps

- Catholyte water pumps

- Power supply and rectifiers

- Main DC bus

- Controls and instrumentation (except local on modules) 


\subsection{PLANT CAPITAL COST ESTIMATES}

Using the SRNL flowsheet, Shaw selected and sized the major pieces of equipment, identified materials of construction, and estimated capital costs. SRNL provided input on the design and cost for the HyS electrolyzer, and Westinghouse provided input on the design and cost of the Decomposition Reactor (Sulfuric Acid Decomposer). Technology Insights prepared the total plant capital cost summary and the plant lifetime costs. SRNL also prepared a capital cost estimate for the HyS equipment using an alternative method to that used by Shaw. The results of this analysis, which shows significantly lower installed capital costs, is given in Section 6.4.2.

\subsubsection{Reference Capital Cost Estimate}

The design in the preceding sections is based on the arrangement of one 500-MW $\mathrm{MW}_{\text {th }}$ PBMR heat source to a HyS water splitting process plant as illustrated in Figure 6-3. The plant outputs are hydrogen and oxygen, while inputs to be accounted are feed water and additional electric power (and nuclear fuel). The resulting plant is made-up of three overall systems: the NHSS, the Hydrogen Production System (HPS), consisting of one or more HyS process trains, and a Power Conversion System (PCS) for generating electricity with steam from surplus heat from the HPS. In addition to the three overall systems, but not shown in the figure, there are structures associated with each overall system, and there is a Balance of Plant (BOP).

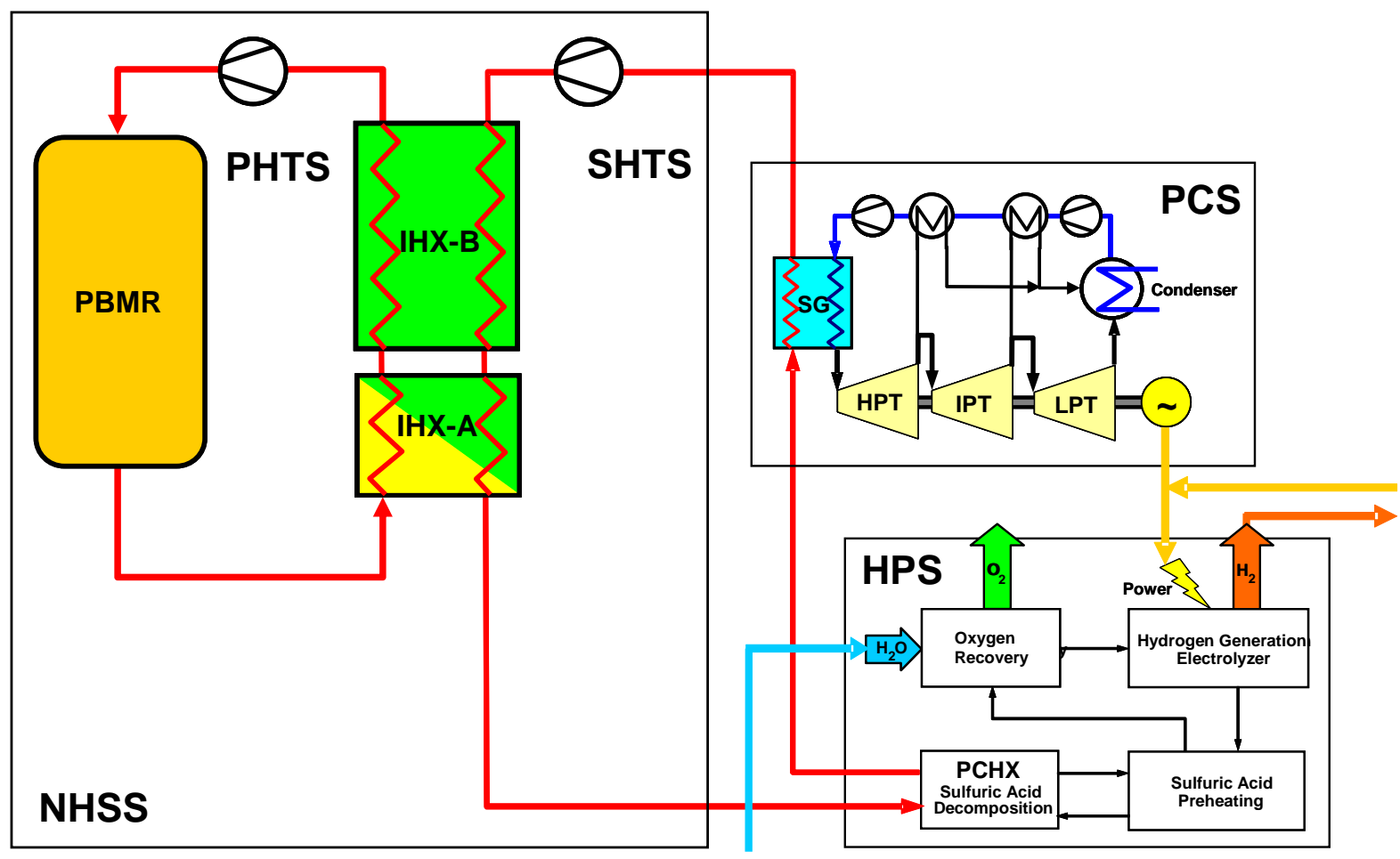

Figure 6-3 PBMR HyS Plant Schematic Configuration 
Shown in the figure are two IHXs which provide transfer of heat from the Primary Heat Transport System (PHTS) to the Secondary Heat Transport System (SHTS). Of the two, IHX-A is the higher temperature heat exchanger and would be made of material with a higher temperature capability.

For the analysis of hydrogen selling price, a mature, four-PBMR unit hydrogen plant is modeled, in order to represent the full commercial potential of the application. Economies derive from sharing of facilities and other cost savings that would come from a mature supply infrastructure. Therefore, the data following in this section and in Section 7.0 are given for a four-unit plant and a "nominal" one-unit plant (where the one-unit plant still has the four-unit economies).

The total capital cost of the nuclear hydrogen plant is made up of the overnight plant capital cost of the total of the overall systems, structures and BOP plus interest during construction. The following is a further breakdown of parts of the plant overall systems:

- Nuclear Heat Supply System (NHSS)

- Reactor Unit System

- Heat Transport System

- Primary Heat Transport System (PHTS)

- Secondary Heat Transport System (SHTS)

o other nuclear systems and subsystems

- Hydrogen Production System (HPS)

- Acid Decomposition Section

- $\mathrm{SO}_{2}$ Electrolysis Section

- Feed \& Utility Section

- Product Purification Section

- Power Conversion System (PCS)

- Balance of Plant (BOP)

Table 6-7 summarizes the plant capital costs (direct depreciable costs). The depreciable costs are all of the uninstalled plant component costs, also called factory or equipment costs, for the overall systems listed above plus their installation costs. The installation costs include for each system direct and indirect labor and expenses of installation, engineering and management of installation, field bulk materials, spares, freight and other cost elements. BOP includes site preparation and all buildings. System roll-up costs include EPC contractor fees. Costs are in 2008 dollars (as per groundrules, Appendix 12.0).

The Nuclear Heat Supply System cost is derived from the costs developed by PBMR (Pty.) Ltd. In particular, the NHSS cost includes the IHX (including its vessel) and the SHTS up to the Acid Decomposer (Decomposition Reactor). It also includes the initial core fuel charge.

The basis for the PCS is a steam turbine-generator shared by four NHSS units. The PCS is scaled from the state-of-the-art $\left(1,050^{\circ} \mathrm{F}, 2500\right.$-psi, no reheat $)$ steam turbine generator system elaborated by Shaw in the pre-conceptual design submitted by the Westinghouse PBMR team 
for the Pre-Conceptual Design Report (PCDR) [25]. Likewise, the BOP costs are from the PCDR estimates.

Table 6-7 Capital Cost Elements of PBMR HyS Water Splitting Plant

\begin{tabular}{|c|c|c|c|}
\hline & $\begin{array}{l}\text { Total for } \\
\text { 4-unit } \\
\text { 2000MW } \\
\text { NHSS } \\
\text { NHSS }\end{array}$ & $\begin{array}{c}\text { Total Costs } \\
\text { per NHSS } \\
\text { Unit }\end{array}$ & $\begin{array}{c}\text { Specific Cost / Unit } \\
\text { Cost }\end{array}$ \\
\hline Nuclear Heat Supply System (NHSS) & $\$ 1,796 \mathrm{M}$ & $\$ 448.9 \mathrm{M}$ & $\begin{array}{c}\$ 900 / \mathrm{kW}_{\text {th }} \\
\$ 2,800 / \mathrm{kg} / \text { day }\end{array}$ \\
\hline \multicolumn{4}{|l|}{ HyS Hydrogen Production System (HPS) } \\
\hline Sulfuric Acid Decomposer ${ }^{1}$ & & & $\$ 11.5 \mathrm{M}$ each $^{1}$ \\
\hline Decomposers, total & $\$ 91.7 \mathrm{M}$ & $\$ 22.9 \mathrm{M}$ & $\$ 70 / \mathrm{kW}_{\text {th }}$ \\
\hline Balance of Decomposition System ${ }^{3}$ & $\$ 732.2 \mathrm{M}$ & $\$ 183.0 \mathrm{M}$ & $\$ 650 / \mathrm{kW}_{\text {th }}$ \\
\hline Total Decomposition System & $\$ 824.0 \mathrm{M}$ & $\$ 206.0 \mathrm{M}$ & $\begin{array}{c}\$ 700 / \mathrm{kW}_{\text {th }} \\
\$ 1,300 / \mathrm{kg} / \text { day }\end{array}$ \\
\hline $\mathrm{SO}_{2}$ Electrolyzer $(\mathrm{SDE})^{2}$ & & & $\$ 270$ per module ${ }^{2}$ \\
\hline Electrolyzers, total ${ }^{3}$ & $\$ 473.0 \mathrm{M}$ & $\$ 118.3 \mathrm{M}$ & $\begin{array}{l}\$ 1,400 / \mathrm{m}^{2} \\
\$ 450 / \mathrm{kW}_{\mathrm{e}}\end{array}$ \\
\hline Balance of $\mathrm{SO}_{2}$ Electrolysis System ${ }^{3}$ & $\$ 226.3 \mathrm{M}$ & $\$ 56.6 \mathrm{M}$ & $\$ 1,000 / \mathrm{kW}_{\mathrm{e}}$ \\
\hline Total Electrolysis Subsystem & $\$ 699.3 \mathrm{M}$ & $\$ 174.8 \mathrm{M}$ & $\begin{array}{c}\$ 1,400 / \mathrm{kW}_{\mathrm{e}} \\
\$ 1,100 / \mathrm{kg} / \text { day }\end{array}$ \\
\hline Feed \& Utility Section & $\$ 66.5 \mathrm{M}$ & $\$ 16.6 \mathrm{M} \$$ & $\$ 100 / \mathrm{kg} /$ day \\
\hline Product Purification Section & $\$ 249.2 \mathrm{M}$ & $\$ 62.3 \mathrm{M} \$$ & $\$ 250 / \mathrm{kg} /$ day \\
\hline Total Process Plant ${ }^{4}$ & $\$ 1,826 \mathrm{M}$ & $\$ 459.7$ & $\begin{array}{c}\$ 2,800 / \mathrm{kg} / \text { day } \\
\$ 2,100 / \mathrm{kW}_{\text {th }} \mathrm{H}_{2}(\mathrm{LHV})\end{array}$ \\
\hline Power Generating System & $\$ 226.4 \mathrm{M}$ & $\$ 56.6 \mathrm{M}$ & $\begin{array}{l}\$ 1,000 / \mathrm{kW} \text { e } \\
\$ 350 / \mathrm{kg} / \text { day }\end{array}$ \\
\hline Balance of Plant & $\$ 585.0 \mathrm{M}$ & $\$ 146.3 \mathrm{M}$ & $\begin{array}{l}\$ 300 / \mathrm{kW}_{\text {th }}^{5} \\
\$ 914 / \mathrm{kg} / \text { day }\end{array}$ \\
\hline Total Direct Depreciable Cost & $\$ 4,432 \mathrm{M}$ & $\$ 1,108 \mathrm{M}$ & $\$ 6,900 / \mathrm{kg} /$ day \\
\hline
\end{tabular}

Notes:

1 each of two per one-reactor plant, each rated $156 \mathrm{MW}_{\text {th }}$, cost is uninstalled

2 each of 192 per reactor unit, cost is uninstalled

3 including all installation costs

4 including EPC fee at 5\%

5 per unit NHSS heat output

The HyS HPS is based on the system design detailed in this report, particularly the estimates summarized in Table 6-6 for the HyS SDE modules, as provided by SRNL. The Acid Decomposer equipment cost was provided by Westinghouse Electric based on a recuperative 
reactor design, and the cost includes the catalyst. The $\mathrm{SO}_{2}$ Electrolyzer System cost includes the AC-DC power conditioning.

Except for the uninstalled costs for the SDE and the Acid Decomposer, all HyS HPS were generated by Shaw using their Factored Automated Cost Estimating System (FACES). This system is based on Shaw's actual cost experience in their related projects over time. The resulting costs from Shaw's FACES are significantly higher than what had been anticipated based on earlier estimates for the HyS system. A discussion of the cost estimation, and a comparison with an alternative cost estimate performed by SNRL, is given in Section 6.4.2 of this report.

The overnight plant capital cost is made up of the base construction cost plus project contingency. The base construction cost consists of the direct and indirect capital costs. The direct costs are the depreciable costs (Table 6-7) and the non-depreciable capital costs. Nondepreciable capital costs are mainly the land under the plant.

Indirect costs are the additional costs which make up the installed cost portion of the total plant depreciable cost include the following categories:

- Engineering services

- Indirect Construction Costs

- Facilities

o Tools

- Insurance

o Building Permits

o Taxes

- Field Office

o Management

- Startup and Testing

- Quality Control

- Home Office

o Project Development and Management

- Nuclear Licensing and Permitting

- Quality assurance \& Configuration control

- Owners' Costs

- Management

o Training

- Startup Expenses

- Consumables

- Initial Reactor Cores

- Initial Fluid and Chemical Inventory

- Spares

The overall plant capital costs are summarized as shown in Table 6-8, including the above indirect costs. A contingency of $10 \%$ is applied to the Total Direct Depreciable Cost (to represent a mean estimate, i.e. a 50\% probability that the costs could be higher or lower). 
These are costs on an "overnight" basis. (This is without interest during construction (IDC). IDC is addressed in the cost analysis discussed in Section 7.0).

Table 6-8 Total Costs of PBMR HyS Water-Splitting Plant

\begin{tabular}{|l|c|c|c|}
\cline { 2 - 4 } \multicolumn{1}{c|}{} & $\begin{array}{c}\text { Total for 4- } \\
\text { unit 2000- } \\
\text { MW }\end{array}$ & $\begin{array}{c}\text { Total Costs } \\
\text { per NHSS } \\
\text { Unit }\end{array}$ & $\begin{array}{c}\text { Specific Cost } / \text { Unit } \\
\text { Cost }\end{array}$ \\
\hline Total Direct Depreciable Cost & $\$ 4,432 \mathrm{M}$ & $\$ 1,108 \mathrm{M}$ & -- \\
\hline Indirect (Owners' and Other) Costs & $\$ 77.9 \mathrm{M}$ & $\$ 19.5 \mathrm{M}$ & -- \\
\hline Total Base Construction Cost & $\$ 4,510 \mathrm{M}$ & $\$ 1,128 \mathrm{M}$ & $\$ 2,200 / \mathrm{kW}_{\text {th }}$ \\
\hline Lantingency & $\$ 443.2 \mathrm{M}$ & $\$ 110.8 \mathrm{M}$ & -- \\
\hline Total Overnight Capital Cost & $\$ 2.0 \mathrm{M}$ & $\$ 0.5 \mathrm{M}$ & $\$ 5,000 / \mathrm{acre}$ \\
\hline & $\$ 4,962 \mathrm{M}$ & $\$ 1,240 \mathrm{M}$ & $\begin{array}{c}\$ 2,500 / \mathrm{kW} \\
\$ 7,700 / \mathrm{kg} / \mathrm{day} \\
\$ 5,600 / \mathrm{kW}\end{array}$ \\
\hline
\end{tabular}

\subsubsection{Alternative Capital Cost Estimates}

The capital cost estimate in Section 6.4.1 was generated by Shaw using their Factored Automated Cost Estimating System (FACES). This system is based on Shaw's actual cost experience in their related projects over time. Actual equipment costs are updated quarterly, and installation costs (labor, bulk materials and other expenses) are benchmarked to Shaw's plant construction experience. For this analysis Shaw assigns a $\pm 50 \%$ confidence, i.e. the costs are considered to have an equal probability of being higher or lower.

The resulting costs from Shaw's FACES are significantly higher than what had been anticipated based on earlier estimates for the HyS system that had taken into account most of the major equipment items (Ref. WSRC-TR-2004-00460 and/or TI's estimates for NHI in 2007). Two factors contribute to the view that the FACES capital and installation cost results herein are conservative, although they are the most in-depth estimates that have been done at that time. The first of these factors is that the input equipment and commodity costs were taken at a time (2nd Quarter 2008) at which industrial commodities were at a peak in cost and equipment costs likewise, and those costs have since retreated. The second factor is that there is no specific industry experience with HyS or other large-scale plants for similar production of pure hydrogen. For this second reason, subjective factors in the cost estimating process are unavoidable, and in accounting for unknowns there is a natural tendency to be conservative. As another reference point for the evaluation of the economics of HyS hydrogen, an alternative preliminary assessment of investment costs of the HPS has been carried out by SRNL using Aspen Icarus software with the "K-base" tool. Icarus calculates the equipment and installation costs to a similar depth as Shaw's system. Icarus has an equipment data base periodically updated by the software vendor. It has algorithms to account for materials of construction and installation similarly to Shaw's system. The same general assumptions described in the previous paragraphs for the Shaw cost estimates were adopted. Year 2008 US \$'s have been used to assess costs, with an escalation factor of 
approximately 1.5 for equipment and materials. This escalation represents the CEPCI change from year 2001, which is the reference year for Aspen Icarus 11.1, to year 2008.

In Table 6-9, Direct Costs for the HyS plant evaluated by Aspen Icarus are reported, along with costs assessed by Shaw. The SRNL Icarus cost estimate for the Sulfuric Acid Decomposer used the uninstalled cost value provided by Westinghouse as the baseline value plus an installation factor of 1.44 (from the Shaw report). The Shaw estimate for the decomposer includes only the uninstalled cost, with the installation costs included in the balance of decomposition section. The uninstalled cost of the SDE as determined by SRNL has been taken into account plus an installation factor of 1.2, which is a target value for skidmounted electrolyzers as provided by TIAX from past H2A analyses. As expected, the Shaw installation costs for the SDE are considerably higher. The costs for the SDE filters and filter housings have been evaluated directly from Shaw report. The rectification system cost has been assessed by Icarus.

Based on the SRNL Icarus estimate, the cost of the $\mathrm{H}_{2} \mathrm{SO}_{4}$ decomposition section represents more than $50 \%$ of the overall direct HyS plant cost, while the Electrolysis section costs are approximately $40 \%$. The SDE installed cost (with 1.2 as the installation factor) represents approximately $73 \%$ of the electrolysis section costs, and it is less than $30 \%$ of the total direct HyS cost assessed by Icarus. The bayonet reactor is responsible for some $16 \%$ of the overall HyS process direct cost.

Based on the numbers in Table 6-9, a comparison between the alternative (SRNL Icarus) and reference (Shaw) HyS plant direct costs is drawn in Table 6-10.

As shown in Table 6-10, the preliminary HPS direct cost evaluated by Shaw is more than 2.3 times higher than the estimate prepared using Icarus as determined by SRNL. Some such difference would be expected, since Shaw reports that in their experience Icarus consistently underestimates bulk material quantities that contribute a large part to the installation costs. The Shaw values have been used in Section 7 of this report to determine the Cost of Hydrogen, with a sensitivity analysis to evaluate the effect of the lower costs estimated by SRNL.

It is particularly interesting to note the large difference between the Shaw and Icarus estimates for the Product Purification Section, where Shaw estimates a direct cost of $\$ 62.3 \mathrm{M}$ and Icarus gives a value of $\$ 11.8 \mathrm{M}$. This section has mostly conventional process equipment, but there are very large differences in the assumed installation factors. Further analysis of the methodology and differences between the two cost estimates should be conducted as a future activity. 
Table 6-9 HyS plant direct costs evaluated by Aspen Icarus

\begin{tabular}{|c|c|c|c|c|}
\hline Item & $\begin{array}{c}\text { Total for } 4 \\
\text { units }(2000 \\
\left.\text { MW }_{\text {th }}\right) \\
\text { NHSS }(\$ M) \\
\text { "Icarus" }\end{array}$ & $\begin{array}{l}\text { Total costs } \\
\text { per NHSS } \\
\text { Unit (\$M) } \\
\text { "Icarus" }\end{array}$ & $\begin{array}{l}\text { Total costs } \\
\text { per NHSS } \\
\text { Unit (\$M) } \\
\text { "Shaw" }\end{array}$ & Comments to Icarus evaluation \\
\hline \multicolumn{5}{|c|}{ HyS HPS } \\
\hline \multicolumn{5}{|c|}{ SAD System } \\
\hline $\begin{array}{l}\text { Decomposer, } \\
\text { total }\end{array}$ & 131.9 & 33.0 & $22.9^{1}$ & $\begin{array}{l}\text { Total installed cost, assuming } \\
\text { uninstalled cost provided by WH } \\
(\$ 22.9 \mathrm{M}) \text { with installation factor } \\
\text { extracted by the Shaw report }(1.44) \text {. } \\
\text { Shaw costs are for uninstalled. }\end{array}$ \\
\hline $\begin{array}{l}\text { Balance of } \\
\text { SAD system }\end{array}$ & 303.6 & 75.9 & $183.0^{2}$ & $\begin{array}{l}\text { Includes all SAD System installed } \\
\text { equipment except installed acid } \\
\text { decomposer. Shaw's costs include } \\
\text { installation cost for the SAD. }\end{array}$ \\
\hline $\begin{array}{l}\text { SAD } \\
\text { System } \\
\text { Total }\end{array}$ & 435.5 & 108.9 & 206.0 & \\
\hline \multicolumn{5}{|c|}{ SDE System } \\
\hline $\begin{array}{l}\text { Electrolyzer, } \\
\text { total }\end{array}$ & 252.0 & 63.0 & $118.3^{2}$ & $\begin{array}{l}\text { Total installed cost, with uninstalled } \\
\text { cost based on SRNL evaluations } \\
\text { ( } \$ 52.5 \mathrm{M} \text { per } 192 \text { modules) and with } \\
\text { installation factor provided by TIAX for } \\
\text { the solar case economic analysis }(1.2)^{3}\end{array}$ \\
\hline $\begin{array}{l}\text { Balance of } \\
\text { SDE System }\end{array}$ & 92.8 & 23.2 & $56.6^{2}$ & $\begin{array}{l}\text { Includes all SDE System installed } \\
\text { equipment except SDE. Costs of SDE } \\
\text { filters ( } \$ 6.35 \mathrm{M}) \text { directly taken from } \\
\text { Shaw report and added to other } \\
\text { equipment costs evaluated by Icarus } \\
\text { (\$10.83M). Additional } \$ 6 \mathrm{M} \text { (Icarus } \\
\text { evaluation) added to account for } \\
\text { rectifiers }\end{array}$ \\
\hline $\begin{array}{l}\text { SDE } \\
\text { System } \\
\text { Total }\end{array}$ & 344.8 & 86.2 & 174.8 & \\
\hline FUS & 22.0 & 5.5 & 16.6 & \\
\hline PPS & 47.2 & 11.8 & 62.3 & \\
\hline $\begin{array}{l}\text { HPS } \\
\text { Direct } \\
\text { Cost }\end{array}$ & 849.5 & 212.4 & $482.7^{4}$ & No further fees added \\
\hline
\end{tabular}

Notes:

${ }^{1}$ Each of two per one-reactor plant, each rated $156 \mathrm{MW}_{\text {th }}$, cost is uninstalled.

2 Includes all installation costs.

3 Installation factor is approximately one-half of value adopted by Shaw.

${ }^{4}$ Includes EPC fee at 5\%. 
Table 6-10 Comparison between reference (Shaw) and alternative (Icarus) HyS plant direct costs

\begin{tabular}{|l|c|}
\hline Item & Shaw / Icarus \\
\hline Decomposers, total & 0.7 \\
\hline Balance of Decomposition System & 2.4 \\
\hline Total SAD System & 1.9 \\
\hline SDEs, total & 1.9 \\
\hline Balance of $\mathrm{SO}_{2}$ Electrolysis System & 2.4 \\
\hline Total SDE System & 2.0 \\
\hline Feed and Utility Section & 3.0 \\
\hline Product Purification Section & 5.3 \\
\hline HPS Direct Cost & 2.3 \\
\hline
\end{tabular}

\subsection{PLANT LIFETIME COSTS}

\subsubsection{Replacement Capital Costs}

During the operation of the HPS, renewal of the electrolyzers and periodic replacement of decomposer internals will be significant ongoing capital expenditures. In addition, for the NHSS the operation at high temperature limits the service life of two significant components. As determined in the NGNP pre-conceptual design, on which this study is based, it will be required to replace the Central Reflector Column of the Reactor Unit at one point before the end of the plant life. A specific study [26] indicates that the higher temperature IHX (IHXA) will also need to be replaced during plant lifetime. Replacement period and installation factors have been estimated for the Central Reflector [25] and for IHX-A [26]. For the Central Reflector and the IHX-A replacements, the plant outage time is included in the calculation of plant lifetime average capacity factor.

For the electrolyzers a regular refurbishment program is estimated at $5 \%$ of original cost. Acid decomposer tubes will be replaced on a 5-year schedule.

Table 6-11 summarizes these capital replacement factors. Costs are in 2008 dollars (as per groundrules, Appendix 12.0). 
Table 6-11 Capital Replacement Costs of HyS Plant, per NHSS Unit

\begin{tabular}{|l|c|}
\hline Reactor Unit Central Reflector Column & $\$ 8.0 \mathrm{M}$ \\
\hline Reflector Replacement Year & $24^{\text {th }}$ \\
\hline & \\
\hline IHX-A cost basis, uninstalled & $\$ 108 / \mathrm{kW}_{\text {th }}{ }^{1}$ \\
\hline IHX-A Renewal Period & $8 \mathrm{yr}$ \\
\hline IHX-A Replacement Cost, first time, installed & $\$ 23.8 \mathrm{M}$ \\
\hline IHX-A Replacement Cost, subsequent, installed & $\$ 16.7 \mathrm{M}$ \\
\hline & \\
\hline Electrolyzer Refurbishment Cost & $\$ 2.63 \mathrm{M} / \mathrm{yr}^{2}$ \\
\hline & \\
\hline Decomposer Tube Replacement Cost & $\$ 4.60 \mathrm{M}$ \\
\hline Decomposer Tube Renewal Period & $5 \mathrm{yr}$ \\
\hline
\end{tabular}

Notes:

${ }^{1}$ basis is heat throughput

$25 \% / y r$

\subsubsection{Operating and Maintenance Costs}

Operating and maintenance costs for the NHSS, PCS and BOP are itemized in Table 6-12, Table 6-13, and Table 6-14. Costs are in 2008 dollars (as per groundrules, Appendix 12.0).

In the division of onsite labor between the overall systems, site security is assigned to the NHSS, since that labor element is predominantly for nuclear security. The BOP is assigned the labor for at-large technicians and general support staff. Staff related to quality, safety and training is assigned to overhead, so that the labor overhead rate is $20 \%$. A basic hourly rate of $\$ 50$ is applied to the direct personnel numbers in the tables to calculate the annual labor cost. 
Table 6-12 Operating and Maintenance Costs of NHSS

\begin{tabular}{|c|c|c|}
\hline & $\begin{array}{c}\text { Total for 4-unit } \\
2,000-\mathrm{MW}_{\text {th }} \text { NHSS }\end{array}$ & $\begin{array}{c}\text { Total Costs } \\
\text { per NHSS Unit }\end{array}$ \\
\hline \multicolumn{3}{|l|}{ Fixed Operating Costs } \\
\hline Total Plant Staff $^{1}$ & 108 & 27 \\
\hline Annual Labor $^{2}$ & $\$ 13,525,000 / \mathrm{yr}$ & $\$ 3,382,000 / \mathrm{yr}$ \\
\hline Annual Licensing, Permits and Fees & $\$ 7,000,000 / \mathrm{yr}$ & $\$ 1,750,000 / \mathrm{yr}$ \\
\hline Maintenance and Repairs & $\$ 441,000 / \mathrm{yr}$ & $\$ 110,000 / \mathrm{yr}$ \\
\hline Nuclear Decommissioning Funding & $\$ 1,464,000 / \mathrm{yr}$ & $\$ 366,000 / \mathrm{yr}$ \\
\hline Helium Supply & $\$ 175,000 / \mathrm{yr}$ & $\$ 44,000 / \mathrm{yr}$ \\
\hline Total Fixed Operating Costs & $\$ 22,605,000 / \mathrm{yr}$ & $\$ 5,651,000 / \mathrm{yr}$ \\
\hline \multicolumn{3}{|l|}{ Variable Operating Costs } \\
\hline Nuclear Fuel Cycle Cost ${ }^{3}$ & $\$ 80,991,000 / \mathrm{yr}$ & $\$ 20,248000 / \mathrm{yr}$ \\
\hline Spent Fuel & $\$ 6,789,000 / \mathrm{yr}$ & $\$ 1,697,000 / \mathrm{yr}$ \\
\hline Radioactive Waste & $\$ 824,000 / \mathrm{yr}$ & $\$ 206,000 / \mathrm{yr}$ \\
\hline Non-Nuclear Waste & $\$ 824,000 / \mathrm{yr}$ & $\$ 206,000 / \mathrm{yr}$ \\
\hline $\begin{array}{l}\text { Total Variable Operating Costs } \\
\text { (without Electricity) }\end{array}$ & $\$ 89,429,000 / \mathrm{yr}$ & $\$ 22,357,000 / \mathrm{yr}$ \\
\hline \multicolumn{3}{|l|}{ Utilities and Feed } \\
\hline Electricity Consumed $^{4}$ & $\$ 75,108,000 / \mathrm{yr}$ & $\$ 18,777,000 / \mathrm{yr}$ \\
\hline Total Variable Operating Costs & $\$ 164,536,000 / \mathrm{yr}$ & $\$ 41,134,000 / \mathrm{yr}$ \\
\hline Total Operating and Maintenance Costs & $\$ 187,182,000 / \mathrm{yr}$ & $\$ 46,785,000 / \mathrm{yr}$ \\
\hline
\end{tabular}

Notes:

${ }^{1}$ full-time equivalent, direct, non-managerial; includes site security staffing

2 calculated at $\$ 50 / \mathrm{hr}$ and $20 \%$ overhead $=\$ 60 / \mathrm{hr}$

3 levelized cost over plant life, based on $\$ 100 /$ PBMR fuel sphere in 2008, 1/2\%/yr escalation

${ }^{4}$ levelized cost over plant life, based on $\$ 60 / \mathrm{MW}_{\mathrm{e}}-\mathrm{hr}$ in $2008,1 \% / \mathrm{yr}$ escalation 
Table 6-13 Operating and Maintenance Costs of PCS

\begin{tabular}{|c|c|c|}
\hline & $\begin{array}{c}\text { Total for 4-unit } \\
2,000-\mathrm{MW}_{\text {th }} \text { NHSS }\end{array}$ & $\begin{array}{c}\text { Total Costs } \\
\text { per NHSS Unit }\end{array}$ \\
\hline \multicolumn{3}{|l|}{ Fixed Operating Costs } \\
\hline Total Plant Staff ${ }^{1}$ & 24 & 6 \\
\hline Annual Labor ${ }^{2}$ & $\$ 3,005,000 / \mathrm{yr}$ & $\$ 751,000 / \mathrm{yr}$ \\
\hline Maintenance and Repairs & $\$ 51,000 / \mathrm{yr}$ & $\$ 13,000 / \mathrm{yr}$ \\
\hline Total Fixed Operating Costs & $\$ 3,057,000 / \mathrm{yr}$ & $\$ 764,000 / y r$ \\
\hline \multicolumn{3}{|l|}{ Variable Operating Costs } \\
\hline \multicolumn{3}{|l|}{ Utilities and Feed } \\
\hline Electricity Consumed $^{3,4}$ & $\$ 3.094,000 / \mathrm{yr}$ & $\$ 773,500 / \mathrm{yr}$ \\
\hline Water Usage & $\$ 3,210,000 / y r$ & $\$ 803,000 / y r$ \\
\hline Total Utilities and Feed & $\$ 6.305,000 / \mathrm{yr}$ & $\$ 1.576,000 / \mathrm{yr}$ \\
\hline Total Operating and Maintenance Costs & $\$ 9.362,000 / \mathrm{yr}$ & $\$ 2.340,000 / \mathrm{yr}$ \\
\hline
\end{tabular}

Notes:

1 full-time equivalent, direct, non-managerial

2 calculated at $\$ 50 / \mathrm{hr}$ and $20 \%$ overhead $=\$ 60 / \mathrm{hr}$

3 disregarding power generated by PCS

4 levelized cost over plant life, based on $\$ 60 / \mathrm{MW}_{\mathrm{e}}-\mathrm{hr}$ in $2008,1 \% / \mathrm{yr}$ escalation 
Table 6-14 Operating and Maintenance Costs of BOP

\begin{tabular}{|c|c|c|}
\cline { 2 - 3 } \multicolumn{1}{c|}{} & $\begin{array}{c}\text { Total for 4-unit } \\
2,000-\mathrm{MW}_{\text {th }} \text { NHSS }\end{array}$ & $\begin{array}{c}\text { Total Costs } \\
\text { per NHSS Unit }\end{array}$ \\
\hline Fixed Operating Costs & & \\
\hline Total Plant Staff $^{1}$ & 36 & 9 \\
\hline Annual Labor $^{2}$ & $\$ 4,508,000 / \mathrm{yr}$ & $\$ 1,127,000 / \mathrm{yr}$ \\
\hline Maintenance and Repairs $^{\text {Total Fixed Operating Costs }}$ & $\$ 1,236,000 / \mathrm{yr}$ & $\$ 309,000 / \mathrm{yr}$ \\
\hline Variable Operating Costs & $\$ 5,744,000 / \mathrm{yr}$ & $\$ 1,436,000 / \mathrm{yr}$ \\
\hline Non-Nuclear Waste & $\$ 2,324,000 / \mathrm{yr}$ & \\
\hline $\begin{array}{c}\text { Total Variable Operating Costs } \\
\text { (without Electricity and Water) }\end{array}$ & $\$ 2,324,000 / \mathrm{yr}$ & $\$ 581,000 / \mathrm{yr}$ \\
\hline Utilities and Feed & & \\
\hline Electricity Consumed & & \\
\hline Total Variable Operating Costs & $\$ 3,000 / \mathrm{yr}$ \\
\hline Total Operating and Maintenance Costs & $\$ 12,063,000 / \mathrm{yr}$ & $\$ 3,015,000 / \mathrm{yr}$ \\
\hline
\end{tabular}

Notes:

1 full-time equivalent, direct, non-managerial

2 calculated at $\$ 50 / \mathrm{hr}$ and $20 \%$ overhead $=\$ 60 / \mathrm{hr}$

${ }^{3}$ levelized cost over plant life, based on $\$ 60 / \mathrm{MW}_{\mathrm{e}}-\mathrm{hr}$ in $2008,1 \% / \mathrm{yr}$ escalation 
In conjunction with the HyS Process Plant sizing and equipment selection detailed in Section 6.3, Shaw has estimated the process plant Operation and Maintenance (O\&M) costs. The bases for these costs are in Table 6-15 and operating and Maintenance costs for the $\mathrm{H}_{2}$ production section are reported in Table 6-16.

Table 6-15 Operating and Maintenance Costs for the HyS Water Splitting Process System

\begin{tabular}{|c|c|}
\hline Staffing: & \\
\hline Operations & 4 persons per shift x 4 shifts \\
\hline Maintenance & 2 persons per shift x 4 shifts +6 day shift only \\
\hline Supervision & 1 supervisor per shift +1 maintenance supervisor \\
\hline Chemicals: & $\$ 2,400 /$ operating day \\
\hline Sulfuric Acid Makeup & $\$ 6,500 /$ operating day \\
\hline Caustic for Acid Blowdown & $\$ 8,900 /$ operating day \\
\hline Total Chemicals & \\
\hline Catalysts, etc.: & $\$ 6,300 /$ operating day \\
\hline Acid Decomposer & $\$ 4,300 /$ operating day \\
\hline ZnO for Desulfurization & $\$ 2,400 /$ operating day \\
\hline Other Catalyst and Mol Sieves & $\$ 13,000 /$ operating day \\
\hline Total Catalysts, etc. & $270 \mathrm{MW}-\mathrm{hr} / \mathrm{hr} ; 23,600 \mathrm{~m} / \mathrm{hr}, 10^{\circ} \mathrm{C} \Delta \mathrm{T}$ \\
\hline Cooling Water & $120 \mathrm{~m}^{3} / \mathrm{hr}$ \\
\hline Process Water & $20 \% / \mathrm{yr} @ \$ 2,500 / \mathrm{element}=\$ 525,000 / \mathrm{yr}$ \\
\hline Replacement Filters & \\
\hline
\end{tabular}


Table 6-16 Operating and Maintenance Costs of HPS

\begin{tabular}{|c|c|c|}
\hline & $\begin{array}{c}\text { Total for 4-unit } \\
2,000-\mathrm{MW}_{\text {th }} \text { NHSS }\end{array}$ & $\begin{array}{c}\text { Total Costs } \\
\text { per NHSS Unit }\end{array}$ \\
\hline \multicolumn{3}{|l|}{ Fixed Operating Costs } \\
\hline Total Plant Staff ${ }^{1}$ & 140 & 35 \\
\hline Annual Labor ${ }^{2}$ & $\$ 17,532,000 / \mathrm{yr}$ & $\$ 4,383,000 / \mathrm{yr}$ \\
\hline Total Fixed Operating Costs & $\$ 17,532,000 / \mathrm{yr}$ & $\$ 4,383,000 / y r$ \\
\hline \multicolumn{3}{|l|}{ Variable Operating Costs } \\
\hline Catalyst and Chemicals & $\$ 30,135,000 / \mathrm{yr}$ & $\$ 7,534,000 / \mathrm{yr}$ \\
\hline Filter replacement & $\$ 2,112,000 / \mathrm{yr}$ & $\$ 582,000 / y r$ \\
\hline $\begin{array}{l}\text { Total Variable Operating Costs } \\
\text { (without Electricity and Water) }\end{array}$ & $\$ 32,247,000 / y r$ & $\$ 8,062,000 / y r$ \\
\hline \multicolumn{3}{|l|}{ Utilities and Feed } \\
\hline Electricity Consumed $^{3}$ & $\$ 320,718,000 / \mathrm{yr}$ & $\$ 80,179,000 / \mathrm{yr}$ \\
\hline Water Used & $\$ 4,434,000 / \mathrm{yr}$ & $\$ 1,108,000 / y r$ \\
\hline Total Utilities and Feed & $\$ 325,166,000 / \mathrm{yr}$ & $\$ 81,292,000 / \mathrm{yr}$ \\
\hline Total Variable Operating Costs & $\$ 357,413,000 / \mathrm{yr}$ & $\$ 89,353,000 / \mathrm{yr}$ \\
\hline Total Operation and Maintenance & $\$ 374,945,000 / \mathrm{yr}$ & $\$ 93,736,000 / \mathrm{yr}$ \\
\hline
\end{tabular}

Notes:

1 full-time equivalent, direct, non-managerial

2 calculated at $\$ 50 / \mathrm{hr}$ and $20 \%$ overhead $=\$ 60 / \mathrm{hr}$

3 levelized cost over plant lifetime, based on $\$ 60 / \mathrm{MW}_{\mathrm{e}}-\mathrm{hr}$ in $2008,1 \% / \mathrm{yr}$ escalation 
Table 6-17 summarizes the plant thermal and electric power balance.

Table 6-17 Additional Cost Factors by Overall System

\begin{tabular}{|c|c|c|c|c|}
\hline & \multicolumn{2}{|c|}{$\begin{array}{c}\text { Thermal Power Consumption / } \\
\text { Generation }\end{array}$} & \multicolumn{2}{|c|}{$\begin{array}{l}\text { Electric Power Consumption / } \\
\text { Generation }\end{array}$} \\
\hline & $\begin{array}{c}\text { Total for 4- } \\
\text { unit 2,000- } \\
\text { MW }_{\text {th }} \text { NHSS } \\
\end{array}$ & $\begin{array}{l}\text { per NHSS } \\
\text { Unit }\end{array}$ & $\begin{array}{l}\text { Total for 4- } \\
\text { unit 2,000- } \\
\mathrm{MW}_{\text {th }} \text { NHSS }\end{array}$ & $\begin{array}{c}\text { per NHSS } \\
\text { Unit }\end{array}$ \\
\hline $\begin{array}{l}\text { Nuclear Heat Supply } \\
\text { System (NHSS) * }\end{array}$ & $2,065 \mathrm{MW}_{\text {th }}$ & $516 \mathrm{MW}_{\text {th }}$ & $-113 \mathrm{MW}_{\mathrm{e}}$ & $-28 \mathrm{MW}_{\mathrm{e}}$ \\
\hline $\begin{array}{l}\text { Hydrogen Production } \\
\text { System (HPS) } \\
\text { from NHSS } \\
\text { from PCS }\end{array}$ & $\begin{array}{l}-1,251 \mathrm{MW}_{\text {th }} \\
-282 \mathrm{MW}_{\mathrm{th}}\end{array}$ & $\begin{array}{r}-313 \mathrm{MW}_{\text {th }} \\
-71 \mathrm{MW}_{\text {th }} \\
\end{array}$ & $-482 \mathrm{MW}_{\mathrm{e}}$ & $-120 \mathrm{MW}_{\mathrm{e}}$ \\
\hline $\begin{array}{l}\text { Power Conversion } \\
\text { System (PCS) } \\
\text { from NHSS } \\
\text { to PCS }\end{array}$ & $\begin{array}{l}-814 \mathrm{MW}_{\text {th }} \\
+282 \mathrm{MW}_{\mathrm{th}}\end{array}$ & $\begin{array}{r}-204 \mathrm{MW}_{\text {th }} \\
+71 \mathrm{MW}_{\text {th }}\end{array}$ & $\begin{array}{l}+212 \\
-5 \\
=207 \mathrm{MW}_{\mathrm{e}}\end{array}$ & $\begin{array}{l}+53 \\
\quad-1.2 \\
=52 \mathrm{MW}_{\mathrm{e}}\end{array}$ \\
\hline Balance of Plant (BOP) & -- & -- & $-6 \mathrm{MW}_{\mathrm{e}}$ & $-1.4 \mathrm{MW}_{\mathrm{e}}$ \\
\hline Totals & -- & -- & - $393 \mathrm{MW}_{\mathrm{e}}$ & - $98 \mathrm{MW}_{\mathrm{e}}$ \\
\hline
\end{tabular}

Note:

* includes $500-\mathrm{MW}_{\text {th }}$ nuclear generation per reactor module minus thermal losses from NHSS plus work added by electric helium circulators 
Table 6-18 summarizes the division of Operation and Maintenance costs between overall systems of the total plant and by category.

Table 6-18 Sum of Operating and Maintenance Costs for Plant

\begin{tabular}{|c|c|c|}
\hline & $\begin{array}{c}\text { Total for 4-unit } \\
\text { 2,000-MW } \text { th }_{\text {NHSS }}\end{array}$ & $\begin{array}{c}\text { Total Costs } \\
\text { per NHSS Unit } \\
\end{array}$ \\
\hline \multicolumn{3}{|l|}{ Fixed Operating Costs } \\
\hline Total Plant Staff & 308 & 77 \\
\hline Annual Labor & $\$ 38,570,000 / \mathrm{yr}$ & $\$ 9,643,000 / \mathrm{yr}$ \\
\hline Annual Licensing, Permits and Fees & $\$ 7,000,000 / y r$ & $\$ 1,750,000 / y r$ \\
\hline Maintenance and Repairs & $\$ 1,728,000 / \mathrm{yr}$ & $\$ 432,000 / \mathrm{yr}$ \\
\hline Nuclear Decommissioning Funding & $\$ 1,464,000 / \mathrm{yr}$ & $\$ 366,000 / y r$ \\
\hline Helium Supply & $\$ 175,000 / \mathrm{yr}$ & $\$ 44,000 / \mathrm{yr}$ \\
\hline Insurance & $\$ 49,616,000 / \mathrm{yr}$ & $\$ 12,404,000 / y r$ \\
\hline Property Taxes & $\$ 49,616,000 / \mathrm{yr}$ & $\$ 12,404,000 / \mathrm{yr}$ \\
\hline Total Fixed Operating Costs & $\$ 148,169,000 / \mathrm{yr}$ & $\$ 37,042,000 / \mathrm{yr}$ \\
\hline \multicolumn{3}{|l|}{ Variable Operating Costs } \\
\hline Nuclear Fuel Cycle Cost & $\$ 80,991,000 / \mathrm{yr}$ & $\$ 20,248,000 / \mathrm{yr}$ \\
\hline Spent Fuel \& Waste Disposal & $\$ 10,761,000 / \mathrm{yr}$ & $\$ 2,690,000 / y r$ \\
\hline Catalyst \& Chemicals \& Filters & $\$ 32,247,000 / \mathrm{yr}$ & $\$ 8,062,000 / \mathrm{yr}$ \\
\hline $\begin{array}{l}\text { Total Variable Operating Costs } \\
\text { (without Electricity and Water) }\end{array}$ & $\$ 123,999,000 / \mathrm{yr}$ & $\$ 31,000,000 / y r$ \\
\hline \multicolumn{3}{|l|}{ Utilities and Feed } \\
\hline Electricity Imported & $\$ 260,474,000 / \mathrm{yr}$ & $\$ 65,118,000 / \mathrm{yr}$ \\
\hline Water Used & $\$ 7,645,000 / \mathrm{yr}$ & $\$ 1,911,000 / \mathrm{yr}$ \\
\hline Total Utilities and Feed & $\$ 268,133,000 / \mathrm{yr}$ & $\$ 67,033,000 / \mathrm{yr}$ \\
\hline Total Variable Operating Costs & $\$ 392,132,000 / y r$ & $\$ 98,033,000 / \mathrm{yr}$ \\
\hline Total Operation and Maintenance & $\$ 540,301,000 / \mathrm{yr}$ & $\$ 135,075,000 / \mathrm{yr}$ \\
\hline Oxygen Byproduct Sales Revenue & $\$ 70,230,000 / \mathrm{yr}$ & $\$ 17,578,000 / y r$ \\
\hline Net of Operating Cost less Revenue & $\$ 470,071,000 / y r$ & $\$ 117,497,000 / y r$ \\
\hline
\end{tabular}




\subsection{COST OF HYDROGEN ESTIMATE}

Whereas the development of a Hydrogen Economy is motivated by foreseen benefits of energy security, lower pollutant emissions and reduced climate change, in the final analysis the figure of merit for production of hydrogen by means of any technology is the minimum price that the product can be sold to the ultimate consumer. This is the price that will recoup the hydrogen production plant's initial and ongoing capital investment, fuel and feed costs and other fixed and variable operating costs and also return a profit to the owner. The price one calculates is strongly influenced by financial assumptions as well as specifics of the particular technology. In this section, a price is calculated for hydrogen from the nuclearpowered HyS water splitting cycle. Cost elements of the nuclear heat source and the process plant are estimated with derivations documented. The resulting HyS price is compared on an equivalent basis to the prices for hydrogen from alternate baseline technologies. These baselines are natural gas steam reforming and alkaline water electrolysis. Sensitivity analysis provides insight to the effects of varying financial and cost inputs for both HyS and the baseline technologies. In particular, the sensitivity analysis highlights the influence of cost uncertainties associated with the technical parameters and component cost estimates of the more developmental HyS cycle components.

\subsection{H2A MODELING TOOLS}

The DOE has sponsored and published a specific tool for the comparison of hydrogen production technologies. This is a result of the H2A Production Analysis Program, which is part of the national Hydrogen Fuel Initiative, and which was conducted by a team from the various DOE divisions, the national laboratories and industrial participants.

The primary objectives of the H2A Production Analysis Program have been as follows:

- Improve the consistency and transparency of the groundrules and assumptions for the economic analyses of hydrogen systems within the DOE hydrogen programs, as well as within related industry programs.

- Develop a tool for consistent analyses and reporting of the economics of hydrogen production and delivery systems, as well as for R\&D direction and portfolio analyses.

- Validate the consistent groundrules, assumptions and analyses methodology through deliberations with a select group of key industrial collaborators, including nuclear utility and vendor representatives.

The H2A model is a spreadsheet-based (Microsoft Excel) calculation tool which gives the required selling price of hydrogen for the input capital and operating cost factors for a hydrogen production plant and for the specified economic parameters, including the rate of 
return on investment. The units of the resultant price are dollars per kilogram which serves to normalize the comparisons and happens to be approximately equal to the price of gasoline with the same energy content on a lower heating value basis. The results of $\mathrm{H} 2 \mathrm{~A}$ have been published on the DOE website [27].

While the tool includes agreed-upon $\mathrm{H} 2 \mathrm{~A}$ reference values for several financial parameters, the user is also given the opportunity to vary parameters such as internal rate of return, plant life, feedstock costs, and tax rate, to examine the technology using their own basis. The calculation part of the tool uses a standard discounted cash flow rate of return analysis methodology to determine the hydrogen selling cost for the desired internal rate of return.

Inflation can be input to the model, but in the discounted cash flow analysis the effect of inflation is nullified except for a small impact on the tax depreciation. For this reason, the calculated selling price for hydrogen is the fixed or levelized price over the plant life in reference year dollars.

There are two versions of the tool - one formatted for central production of hydrogen and one for "forecourt" production. The latter is for analysis of smaller-scale hydrogen plants that would be integrated with dispensing of the hydrogen product to fuel cell vehicles. This study concerns large central production with transport to a relatively distant set of users, and so for these analyses only the former version applies.

In 2007, DOE reconvened the H2A participants to review and refine the modeling tools and update the cases to be modeled. Refinements to the modeling tools have been based on improvements for convenience and correction of small errors found in the interim by users and by the original developers. The analyses in this report utilize the latest (2007-2008) tool, which are referred to as H2A Production Model, version 2.0.

\subsection{HYDROGEN PRICE BASELINES}

The two presently commercial hydrogen production technologies are natural gas steam reforming and alkaline water electrolysis. There are other methods of hydrogen production, but they have limited application to small volume production, such as to supply cooling gas to power plant generators, to provide very high purity hydrogen for laboratory use and in making hydrogen as a byproduct to oxygen production.

These two technologies for hydrogen are described briefly following, and for each the hydrogen price is calculated using the H2A methodology. These calculations use present day costs of commercially available components and systems in the same 2020 time frame as the nuclear HyS technology, and costs are reported unless otherwise noted in 2008 dollars.

\subsubsection{Natural Gas Steam Reforming}

The SMR process is used to convert natural gas into hydrogen. Methane generally constitutes $95 \%$ of natural gas by molar fraction in the condition gas is distributed. Methane 
reacts with steam in a two-stage chemical process according to the following equations, producing hydrogen and $\mathrm{CO}_{2}$ :

$$
\begin{aligned}
& \text { (catalytic reformer) } \mathrm{CH}_{4}+\mathrm{H}_{2} \mathrm{O}+\text { heat } \rightarrow \mathrm{CO}+3 \mathrm{H}_{2} \text {, } \\
& \text { (water gas shift reaction) } \mathrm{CO}+\mathrm{H}_{2} \mathrm{O} \leftrightarrow \mathrm{CO}_{2}+\mathrm{H}_{2}+\text { heat. }
\end{aligned}
$$

The $\mathrm{CO}_{2}$ produced in these reactions can be captured relatively easily.

Natural gas is both the feed to the process and the heat source for the first of the two reactions. That heat comes from simple atmospheric combustion, as follows:

$$
\mathrm{CH}_{4}+2 \mathrm{O}_{2} \rightarrow \mathrm{CO}_{2}+2 \mathrm{H}_{2} \mathrm{O}+\text { heat. }
$$

The $\mathrm{CO}_{2}$ produced from combustion, which would ordinarily go out up a stack, is difficult and expensive to capture.

SMR is the conventional industrial process for large-scale hydrogen production today. This is hydrogen primarily used in the oil refining and petrochemical industries. Future SMR plants will use essentially the same technology but with some expected improved efficiency and anticipated lower capital cost. An H2A analysis of advanced SMR [28] is used for the baseline calculation. The case used corresponds to present technology for SMR with $\mathrm{CO}_{2}$ capture and sequestration with efficiencies and costs projected for 2025. The $\mathrm{CO}_{2}$ is captured from both the syngas product stream (99\% effective) and the combustion stack (90\% effective) by aqueous amine solution. The reference model was used with minimal changes. One input change made for this is to factor plant capital costs from 2005 to mid2008 dollars by a multiplier of 1.25 based upon changes to costs of chemical equipment, labor and engineering [29].

The SMR hydrogen selling price will be most sensitive to the cost of natural gas. Since natural gas price is expected to rise at a higher rate than general inflation in the future, the $\mathrm{H} 2 \mathrm{~A}$ calculation tool was modified to enter a fixed percentage real escalation rate (that is an escalation above the rate of general inflation) for natural gas. The range of recent historical natural gas cost is $\$ 8.00 / \mathrm{MMBtu}$, which reflects the 2007 year price for industrial gas [30], to $\$ 10.00 / \mathrm{MMBtu}$, which is a data point from mid 2008 [31]. For real escalation, a rate of $2 \%$ is estimated based on recent years' natural gas rate of price increase. Because the input cost is escalated, the hydrogen selling price is a levelized cost over the 40-year plant lifetime deflated back to 2007 dollars.

Future natural gas price and to a lesser degree $\mathrm{CO}_{2}$ costs are the two main driving factors for SMR economics. Table 7-1 shows the results of the analysis for the hydrogen price from SMR with these factors varied and based upon the advanced SMR technology case. Costs are in 2008 dollars (as per groundrules, Appendix 12.0). 
Table 7-1 Hydrogen from Natural Gas by Advanced Steam Methane Reforming

\begin{tabular}{|l|c|c|c|}
\cline { 2 - 4 } \multicolumn{1}{c|}{} & $\begin{array}{c}\text { Natural Gas } \\
\text { Cost } * \\
\$ / \mathrm{MMBtu}\end{array}$ & $\begin{array}{c}\mathrm{CO}_{2} \text { Emission } \\
\text { Penalty } *^{\dagger} \\
\$ / \mathrm{MT}\end{array}$ & $\begin{array}{c}\text { Hydrogen } \\
\text { Selling Price } \\
/ \mathrm{kg}\end{array}$ \\
\hline Reference Case & 8 & 30 & 2.16 \\
\hline Increased Natural Gas Cost & 12 & 30 & 2.93 \\
\hline Increased $\mathrm{CO}_{2}$ Cost & 8 & 100 & 2.26 \\
\hline $\begin{array}{l}\text { Both Higher Natural Gas and } \\
\mathrm{CO}_{2} \text { Costs }\end{array}$ & 12 & 100 & 3.02 \\
\hline
\end{tabular}

* No real escalation in natural gas cost

$\dagger \$ 30 / \mathrm{MT} \mathrm{CO}_{2}$ is $\$ 110 / \mathrm{MT} \mathrm{C} ; \$ 100 / \mathrm{MT} \mathrm{CO}_{2}$ is $\$ 367 / \mathrm{MT} \mathrm{C}$

The sensitivity of the hydrogen price to natural gas cost is further demonstrated in Figure 7-1 for cases with and without the $2 \%$ gas price escalation in the model. Escalation is also included for the small amount of electricity used by the SMR plant in the model and for the $\mathrm{CO}_{2}$ costs. In such an analysis that includes real escalation, the forecast selling price of hydrogen may increase significantly, depending on the escalation rate.

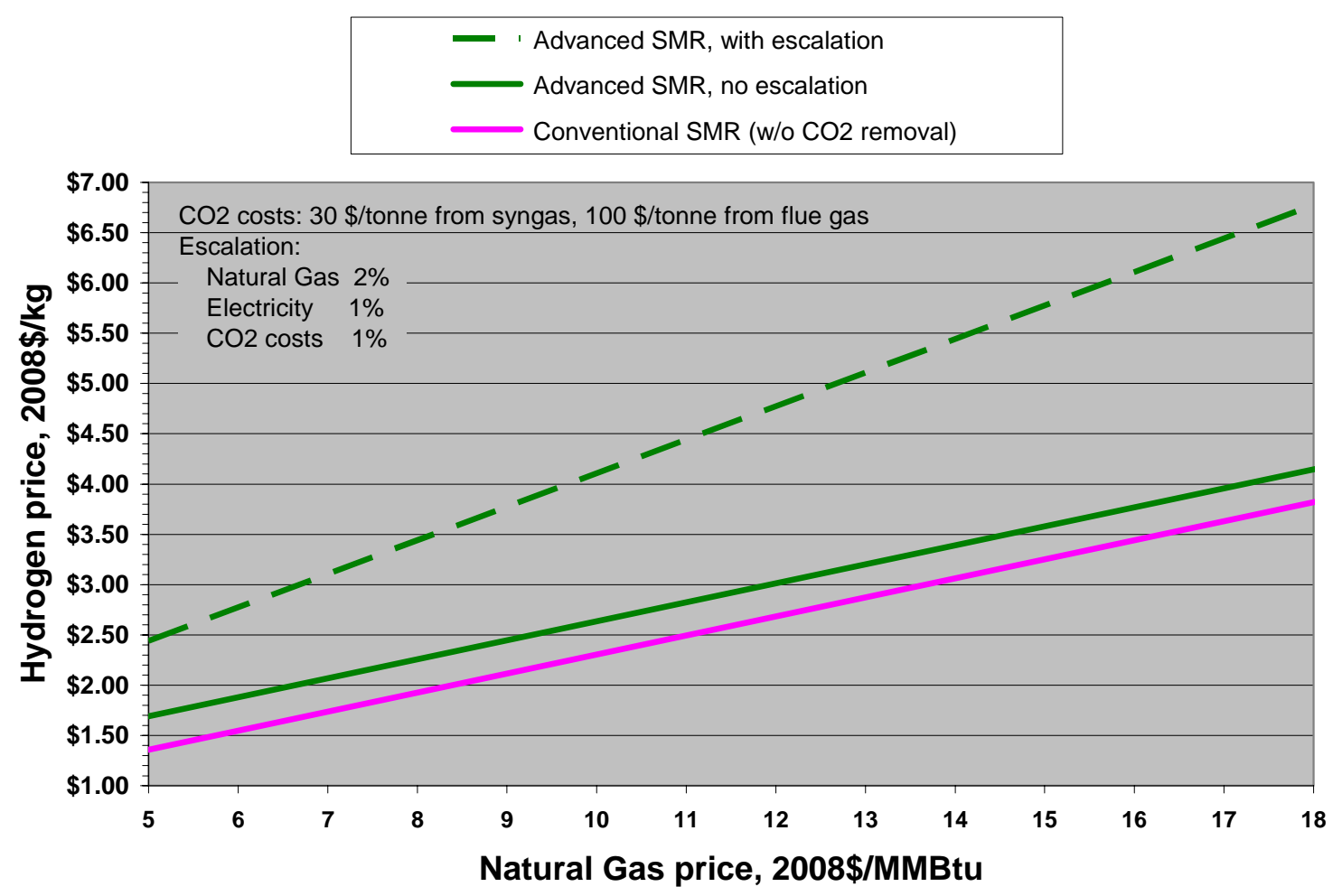

Figure 7-1 $\mathbf{H}_{2}$ Price from SMR as a Function of Natural Gas Cost with Escalation 


\subsubsection{Alkaline Water Electrolysis}

Water electrolysis is the process using direct electric current to split water, as in the classic tabletop high-school experiment. It is sometimes used, more so in the past, for industrial hydrogen generation where electricity is economically priced. It is referred to as alkaline electrolysis because potassium hydroxide $(\mathrm{KOH})$ is added to the water as an electrolyte. There is one manufacturer of large-scale electrolysis units, Hydrogen Technologies, a division of StatoilHydro, formerly Norsk Hydro [32]. Their production plants comprise multiple units having many electrolysis cells. In conventional electrolysis cells the electrodes utilize non-platinum group catalysts, and a membrane separates the electrodes so that the hydrogen and oxygen products do not mix. Significant effort is underway to improve the performance of conventional alkaline electrolysis. With partial DOE funding, General Electric has been pursuing two avenues - improved electrodes and lower manufacturing cost [33].

Two H2A cases posted on the DOE website utilize grid electricity for conventional electrolysis [34]. One change made is an increase in capital costs from 2005 to 2008, as done for the SMR baseline case. The two cases are current conventional alkaline electrolysis technology and future electrolyzer technology. In the analysis of current electrolysis the model uses performance data from StatoilHydro of an efficiency of $74 \%$ (HHV basis). An electrolyzer cost of $\$ 1000 / \mathrm{kW}_{\mathrm{e}}$ (2008 dollars) was used herein based on specific pricing [35].

For future (2030) grid electrolysis the H2A model includes an electrolyzer cost of $\$ 375 / \mathrm{kW}_{\mathrm{e}}$ in 2008 dollars. The cost of $\$ 375 / \mathrm{kW}_{\mathrm{e}}\left(\$ 300 / \mathrm{kW}_{\mathrm{e}}\right.$ in 2005 dollars $)$ is a DOE H2A program consensus [36] based on a target for fuel cell costs set in the DOE fuel cell vehicle program.

For all cases, a credit is included in the hydrogen price for byproduct oxygen from the electrolysis process at \$40/MT.

The dominant cost input factors for the electrolysis baseline case are the capital cost of the electrolyzers and the cost of electric energy used. Input electricity cost for a reference point baseline calculation is $\$ 60 / \mathrm{MW}_{\mathrm{e}}-\mathrm{hr}$, which is representative of recent industrial electricity pricing [37], although unlike natural gas pricing for which there is a nationwide market, the price of electricity is highly variable region-to-region. Table 7-2 shows the results of the analysis for the hydrogen price from electrolysis with the capital and electric cost factors varied, in these cases without any escalation of electricity cost. Costs are in 2008 dollars (as per groundrules, Appendix 12.0). 
Table 7-2 Hydrogen from Conventional Alkaline Electrolysis

\begin{tabular}{|l|c|c|c|}
\cline { 2 - 4 } \multicolumn{1}{c|}{} & $\begin{array}{c}\text { Electrolyzer } \\
\text { Capital Cost* } \\
\$ / \mathrm{kW}_{\mathrm{e}}\end{array}$ & $\begin{array}{c}\text { Electricity } \\
\mathrm{Cost} \dagger \\
\$ / \mathrm{MWh}\end{array}$ & $\begin{array}{c}\text { Hydrogen } \\
\text { Selling Price } \\
\$ / \mathrm{kg}\end{array}$ \\
\hline Reference Case & 1000 & 60.00 & 5.57 \\
\hline Future Electrolyzer & 375 & 60.00 & 4.19 \\
\hline $\begin{array}{l}\text { Future Electrolyzer and } \\
\text { Higher Electricity Cost }\end{array}$ & 375 & 90.00 & 5.92 \\
\hline
\end{tabular}

* uninstalled modular equipment cost, 2008 dollars

$\dagger$ no real escalation in electricity cost

As with the natural gas cost in the SMR baseline analysis, the H2A model was modified to include a $1 \%$ real escalation in the electric power cost as an option. Figure 7-2 shows the effect of electricity cost on the hydrogen selling price with and without real electricity price escalation for the current electrolyzer cost and the projected most optimistic future case.

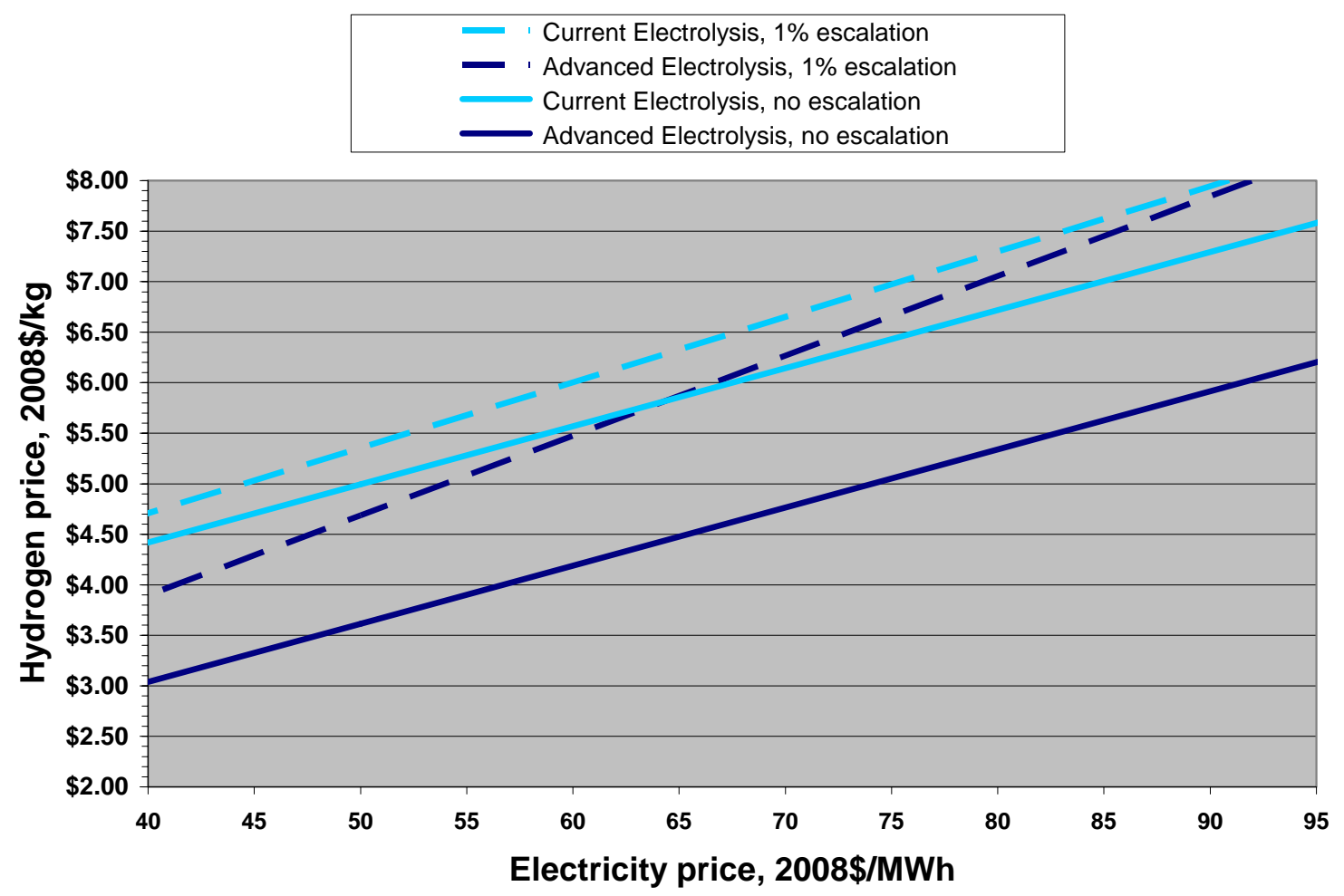

Figure 7-2 Hydrogen Price from Electrolysis as a Function of Electricity Cost 


\subsection{HYBRID SULFUR PRICE CALCULATION INPUT}

Costs have been developed in this study for the plant configuration and heat balance presented in Sections 4.0 and 5.0. These are the initial capital costs, the lifetime periodic replacement costs, fixed operation and maintenance costs and variable operation and maintenance costs (those proportional to the plant production). Variable operation costs include the nuclear fuel, imported electric power and a credit for oxygen sale. These cost elements make-up the input data to the $\mathrm{H} 2 \mathrm{~A}$ analysis tool.

\subsubsection{Economic/Financial Assumptions}

The H2A program not only produced an analysis tool for the comparison of costs for hydrogen technologies, but it also developed a set of assumptions for economic and financial factors that by general consensus could be applied to assure that the comparisons are on a reasonable basis. The H2A modeling tool as published [27] is populated with these economic factors, which can be accepted or modified. For this analysis, the assumptions are generally the H2A "default" values, with exceptions. Table 7-3 summarizes the principal financial and related assumptions for the $\mathrm{HyS}$ cost analysis, and the larger list of $\mathrm{H} 2 \mathrm{~A}$ program groundrules are in Appendix 12.0.

Table 7-3 Major Assumptions for Analysis of HyS Economics

\begin{tabular}{|l|c|}
\hline Reference Dollar Year & $2^{\text {nd }}$ Quarter 2008 \\
\hline Assumed Start-up Year & 2030 \\
\hline Plant Maturity Assumption & $\mathrm{N}^{\text {th }}$ of a kind plant \\
\hline Facility Sharing Assumption & $4 \times 500 \mathrm{MW}_{\text {th }}$ modular reactors \\
\hline Financing & $100 \%$ Equity \\
\hline After-Tax Real IRR & $10 \%$ \\
\hline Project Overall Capital Cost Contingency & $10 \%$ \\
\hline Plant Life & 40 years \\
\hline Lifetime Capacity Factor & $94 \%$ \\
\hline Construction Period & 3 years \\
\hline Costs in Construction Years & $25 \% / 45 \% / 30 \%$ \\
\hline Start-up Period & 1 year \\
\hline Income Tax Rate (composite) & $38.9 \%$ \\
\hline Property Tax Rate & $1 \%$ of Overnight Capital Cost \\
\hline Insurance Rate & $1 \%$ of Overnight Capital Cost \\
\hline Working Capital & $15 \%$ of Incremental Change in \\
\hline
\end{tabular}




\subsubsection{Component Cost Data and Bases}

Cost elements for the HyS nuclear water splitting plant are divided into the initial capital costs, the recurring capital expenses and the operating and maintenance costs. These costs apply to the major parts of the overall plant: the NHSS, the HyS HPS, the electricity generating PCS and the site (civil works) and BOP. These costs are summarized in Sections 6.4 and 6.5. In the next section are the results from the $\mathrm{H} 2 \mathrm{~A}$ computer program calculation with the analysis assumptions detailed above.

Table 7-4 is a summary of the major overall parameters for these analyses. The power conversion system costs are included for the steam turbine-generator and supporting systems that utilize the surplus heat from the process. However the plant imports additional electricity, and so there is an additional element of electric power cost in operation.

\section{Table 7-4 Overall Cost and Performance Factors for Analysis}

\begin{tabular}{|c|c|c|}
\hline \multicolumn{3}{|l|}{ Major Plant Parameters } \\
\hline \multirow[b]{2}{*}{ Nuclear Reactor Power } & 4-unit NHSS & 1 NHSS Unit \\
\hline & $2,000 \mathrm{MW}_{\text {th }}$ & $500 \mathrm{MW}_{\text {th }}$ \\
\hline PCHX Heat Input & $1250 \mathrm{MW}_{\text {th }}$ & $313 \mathrm{MW}_{\text {th }}$ \\
\hline Plant $\mathrm{H}_{2}$ Output & $\begin{array}{c}7.4 \mathrm{~kg} / \mathrm{s} \\
264 \times 10^{6} \mathrm{SCFD}\end{array}$ & $\begin{array}{c}1.85 \mathrm{~kg} / \mathrm{s} \\
66 \times 10^{6} \mathrm{SCFD}\end{array}$ \\
\hline \multirow{2}{*}{$\begin{array}{l}\text { Electric Power Generated } \\
\text { Additional Electricity Imported }\end{array}$} & $224 \mathrm{MW}_{\mathrm{e}}$ & $56 \mathrm{MW}_{\mathrm{e}}$ \\
\hline & $380 \mathrm{MW}_{\mathrm{e}}$ & $95 \mathrm{MW}_{\mathrm{e}}$ \\
\hline \multicolumn{3}{|l|}{ Major Input / Byproduct Costs ${ }^{1}$} \\
\hline \multirow{2}{*}{$\begin{array}{l}\text { Cost of Electricity, Levelized }{ }^{2} \\
\text { Cost of Feed Water }\end{array}$} & \multicolumn{2}{|c|}{$\$ 80.8 / \mathrm{MW}_{\mathrm{e}}-\mathrm{hr}$} \\
\hline & \multicolumn{2}{|c|}{$\$ 0.0017 / \mathrm{gal}$} \\
\hline Price for $\mathrm{O}_{2}$ By-product & \multicolumn{2}{|c|}{$\$ 0.04 / \mathrm{kg}$} \\
\hline
\end{tabular}

Notes:

${ }^{1} 2008$ dollars

$2 \$ 60 / \mathrm{MW}_{\mathrm{e}}-\mathrm{hr}$ in 2008 , escalated at $1 \% / \mathrm{yr}$

\subsubsection{Hydrogen from the HyS Cycle}

From the H2A analysis, applying the groundrules and cost elements detailed above, a selling price for hydrogen is calculated. This cost is for the hydrogen product with credit for the parallel production of oxygen. The results here do not exercise the option to add a credit for not producing $\mathrm{CO}_{2}$, because the selling cost will be compared to alternative technologies for hydrogen for which mitigation of $\mathrm{CO}_{2}$ production is included as a cost and/or tax.

The H2A modeling tool as published is based on an assumption that all costs and the selling price have the same rate of inflation. Energy costs are expected to rise more rapidly than general inflation, and so a modification to the $\mathrm{H} 2 \mathrm{~A}$ model is made to make the analysis more 
realistic. For this analysis escalation beyond the rate of inflation has been included at $1 \frac{1}{2} \% / \mathrm{yr}$ for the nuclear fuel and 1\%/yr for the electric power imported.

The hydrogen price for the base case of the HyS plant is $\$ 6.18 / \mathrm{kg}$ of product $(\$ 5.34 / \mathrm{kg}$ of product with HPS direct costs assessed by Icarus as reported in Section 6.4.2). In an alternative analysis, without $1 \%$ real escalation on cost of import electricity consumed in the process, the price is $\$ 5.85 / \mathrm{kg}$. If the $\mathrm{O}_{2}$ byproduct credit is subtracted, then the $\mathrm{H}_{2}$ price is $\$ 6.51 / \mathrm{kg}$ (\$5.66/kg with Icarus evaluation). In Section 7.4 , the results are presented for sensitivity analysis of the hydrogen price calculation, and the electricity escalation rate and the $\mathrm{O}_{2}$ by-product credit are included in the parameters considered.

\section{Table 7-5 Capital Cost Summary}

\begin{tabular}{|c|c|c|c|c|}
\hline & \multicolumn{3}{|c|}{ Total Costs } & \multirow[t]{2}{*}{ Specific Costs $^{2}$} \\
\hline & $\begin{array}{l}\text { Total for 4-unit } \\
2000-M_{\text {th }} \\
\text { NHSS (Shaw) }\end{array}$ & $\begin{array}{c}\text { Total Costs } \\
\text { per NHSS } \\
\text { Unit (Shaw) }\end{array}$ & $\begin{array}{c}\text { Total Costs } \\
\text { per NHSS } \\
\text { Unit (Icarus) }\end{array}$ & \\
\hline $\begin{array}{l}\text { Total Overnight } \\
\text { Capital Cost (from } \\
\text { Table 6-8) }\end{array}$ & $\$ 4,962 \mathrm{M}$ & $\$ 1,240 \mathrm{M}$ & $\$ 967 \mathrm{M}^{3}$ & $\begin{array}{c}\$ 2,500 / \mathrm{kW}_{\text {th }} \\
\$ 7,700 / \mathrm{kg} / \text { day } \\
\$ 5,600 / \mathrm{kW}_{\text {th }} \mathrm{H}_{2} \\
(\mathrm{LHV})\end{array}$ \\
\hline $\begin{array}{l}\text { Interest During } \\
\text { Construction }^{1}\end{array}$ & $\$ 794 \mathrm{M}$ & $\$ 161 \mathrm{M}$ & $\$ 126 \mathrm{M}^{4}$ & \\
\hline $\begin{array}{l}\text { Total Capital } \\
\text { Investment }\end{array}$ & $\$ 5,756 \mathrm{M}$ & $\$ 1,400 \mathrm{M}$ & $\$ 1,093 \mathrm{M}$ & $\begin{array}{c}2,800 \$ / \mathrm{kWt} \\
\$ 8,750 / \mathrm{kg} / \mathrm{d} \\
\$ 6,300 / \mathrm{kW}_{\text {th }} \mathrm{H}_{2} \\
(\mathrm{LHV})\end{array}$ \\
\hline
\end{tabular}

1 Actual cost of equity (10\% rate) since no debt in calculation.

2 Refers to costs evaluated by Shaw.

3 Value calculated by adding HPS direct depreciable costs from Icarus to costs of NHSS, PGS, and BOP provided by Shaw. Total Overnight Capital Cost evaluated by Shaw approach, described above.

$4 \quad$ Value calculated by linearly scaling Shaw value. 
Table 7-6 Hydrogen Price Components Summary

\begin{tabular}{|c|c|c|c|c|}
\hline & $\begin{array}{c}\$ / k g \\
\text { (Shaw) }\end{array}$ & $\begin{array}{c}\% \\
\text { (Shaw) }\end{array}$ & $\begin{array}{c}\$ / \mathrm{kg} \\
\text { (Icarus) }\end{array}$ & $\begin{array}{c}\% \\
\text { (Icarus) }\end{array}$ \\
\hline Capital Charge & 4.01 & 65 & 3.19 & 59 \\
\hline $\begin{array}{l}\text { Fixed O\&M: } \\
\text { Labor, Taxes, Insurance, Annual Licensing, } \\
\text { Permits and Fees, Material Costs for Maintenance } \\
\text { And Repairs, Nuclear Decommissioning Funding, } \\
\text { Helium Make-up }\end{array}$ & 0.71 & 11 & 0.71 & 13 \\
\hline $\begin{array}{l}\text { Variable O\&M: } \\
\text { Nuclear Fuel, Process Catalyst and Chemical } \\
\text { Consumption and Waste Disposal }\end{array}$ & 0.57 & 9 & 0.57 & 11 \\
\hline $\begin{array}{l}\text { Utilities and Feed: } \\
\text { Electric Power and Process Water }\end{array}$ & 1.22 & 20 & 1.22 & 23 \\
\hline Byproduct Credit $\left(\mathrm{O}_{2}\right)$ & -0.32 & -5 & -0.32 & -6 \\
\hline Total Hydrogen Cost (Year 2008 Real \$/kg) & 6.18 & 100 & 5.37 & 100 \\
\hline
\end{tabular}


Table 7-7 Hydrogen Price Components Detail, $\$ / \mathrm{kg} \mathrm{H}_{2}$, Reference (Shaw) Basis

\begin{tabular}{|c|c|c|c|c|c|c|c|}
\hline & NHSS & HPS & PCS & $\mathrm{BOP}$ & Other $^{1}$ & Total & $\%$ \\
\hline \multicolumn{8}{|l|}{ Capital Charges } \\
\hline Overnight Capital & 1.34 & 1.37 & 0.17 & 0.44 & 0.06 & 3.38 & 55 \\
\hline Interest During Constr. & 0.17 & 0.18 & 0.02 & 0.06 & 0.01 & 0.44 & 7 \\
\hline Total Initial Capital & 1.52 & 1.55 & 0.19 & 0.50 & 0.07 & 3.82 & 62 \\
\hline Replacement Capital & 0.02 & 0.02 & - & - & 0.15 & 0.19 & 3 \\
\hline Total Capital Charge & 1.55 & 1.57 & 0.19 & 0.50 & 0.22 & 4.01 & 65 \\
\hline \multicolumn{8}{|l|}{ Fixed Operating Costs } \\
\hline Annual Labor & 0.06 & 0.08 & 0.01 & 0.02 & - & 0.18 & 2.9 \\
\hline $\begin{array}{l}\text { Annual Licensing, Permits } \\
\text { and Fees }\end{array}$ & 0.03 & - & - & - & - & 0.03 & 0.5 \\
\hline Maint. and Repairs & 0.002 & 0.00 & - & 0.01 & - & 0.01 & 0.1 \\
\hline Nuclear Decomm. Funding & 0.007 & - & - & - & - & 0.01 & 0.1 \\
\hline Helium Supply & 0.001 & - & - & - & - & 0.00 & 0.0 \\
\hline Insurance & - & - & - & - & 0.23 & 0.23 & 3.7 \\
\hline Property Tax & - & - & - & - & 0.23 & 0.23 & 3.7 \\
\hline Total Fixed Operating Costs & 0.10 & 0.08 & 0.01 & 0.03 & 0.47 & 0.68 & 11 \\
\hline \multicolumn{8}{|l|}{ Variable Operating Costs } \\
\hline Spent Fuel, Waste Disposal & 0.04 & - & - & 0.01 & - & 0.05 & 0.8 \\
\hline Nuclear Fuel Cycle $^{2}$ & 0.37 & - & - & - & - & 0.37 & 6 \\
\hline $\begin{array}{l}\text { Catalysts, Chemicals, } \\
\text { Filters } \\
\end{array}$ & - & 0.15 & - & - & - & 0.15 & 2 \\
\hline $\begin{array}{l}\text { Total Cost (w/o Electricity or } \\
\text { Water) }\end{array}$ & 0.41 & 0.15 & - & 0.01 & - & 0.57 & 9 \\
\hline \multicolumn{8}{|l|}{ Utilities and Feed } \\
\hline Electricity Generated $^{3}$ & - & - & -0.65 & - & - & -0.65 & - \\
\hline Electricity Consumed $^{3}$ & 0.34 & 1.47 & 0.01 & 0.02 & - & 1.84 & - \\
\hline Electricity Imported $^{3}$ & - & - & - & - & - & 1.19 & 19 \\
\hline Water Consumption & - & 0.02 & 0.01 & - & - & 0.04 & 1 \\
\hline Total Utilities and Feed & 0.34 & 1.49 & -0.62 & 0.02 & - & 1.23 & 20 \\
\hline $\begin{array}{l}\text { Total Variable Operating } \\
\text { Costs }\end{array}$ & 0.75 & 1.63 & -0.62 & 0.03 & - & 1.79 & 29 \\
\hline Total O\&M Costs & 0.86 & 1.71 & -0.61 & 0.06 & 0.47 & 2.47 & 40 \\
\hline Subtotal $\mathrm{H}_{2}$ Cost & 2.40 & 3.29 & -0.41 & 0.55 & 0.68 & 6.51 & 105 \\
\hline $\mathrm{O}_{2}$ By-product Credit $^{4}$ & - & -0.32 & - & - & - & -0.32 & -5 \\
\hline Final $\mathrm{H}_{2}$ Price & 2.40 & 2.97 & -0.41 & 0.55 & 0.68 & 6.18 & 100 \\
\hline$\%$ of price & 39 & 48 & -7 & 9 & 11 & 100 & - \\
\hline
\end{tabular}

Notes:

${ }^{1}$ For initial capital cost this is the Indirect (Owners' and Other) Costs; for replacement capital this is the sum of globally applied $1 / 2 \%$ unplanned replacement capital and charge for $15 \%$ working capital

2 levelized cost over plant lifetime, based on $\$ 100$ per PBMR fuel sphere in 2008 escalated at $1 / 2 \% / y r$

3 levelized cost over plant lifetime, based on $60 \$ / \mathrm{MW}_{\mathrm{e}}-\mathrm{hr}$ in 2008 escalated at $1 \% / \mathrm{yr}$

${ }^{4}$ assigned arbitrarily to the HPS 
Table 7-8 Hydrogen Price Components Detail, $\$ / \mathrm{kg} \mathrm{H}_{2}$, Alternative (Icarus) Basis

\begin{tabular}{|c|c|c|c|c|c|c|c|}
\hline & NHSS & HPS & PCS & BOP & Other $^{1}$ & Total & $\%$ \\
\hline \multicolumn{8}{|l|}{ Capital Charges } \\
\hline Overnight Capital & 1.34 & 0.63 & 0.17 & 0.44 & 0.06 & 2.65 & 50 \\
\hline Interest During Constr. & 0.17 & 0.08 & 0.02 & 0.06 & 0.01 & 0.34 & 6 \\
\hline Total Initial Capital & 1.52 & 0.72 & 0.19 & 0.50 & 0.07 & 3.00 & 56 \\
\hline Replacement Capital & 0.02 & 0.01 & - & - & 0.15 & 0.18 & 3.3 \\
\hline Total Capital Charge & 1.55 & 0.73 & 0.19 & 0.50 & 0.22 & 3.19 & 60 \\
\hline \multicolumn{8}{|l|}{ Fixed Operating Costs } \\
\hline Annual Labor & 0.06 & 0.08 & 0.01 & 0.02 & - & 0.18 & 3.4 \\
\hline $\begin{array}{l}\text { Annual Licensing, Permits } \\
\text { and Fees }\end{array}$ & 0.03 & - & - & - & - & 0.03 & 0.6 \\
\hline Maint. and Repairs & 0.002 & 0.00 & - & 0.01 & - & 0.01 & 0.2 \\
\hline Nuclear Decomm. Funding & 0.007 & - & - & - & - & 0.01 & 0.2 \\
\hline Helium Supply & 0.001 & - & - & - & - & 0.00 & 0.0 \\
\hline Insurance & - & - & - & - & 0.23 & 0.23 & 4.3 \\
\hline Property Tax & - & - & - & - & 0.23 & 0.23 & 4.3 \\
\hline Total Fixed Operating Costs & 0.10 & 0.08 & 0.01 & 0.03 & 0.47 & 0.68 & 13 \\
\hline \multicolumn{8}{|l|}{ Variable Operating Costs } \\
\hline Spent Fuel, Waste Disposal & 0.04 & - & - & 0.01 & - & 0.05 & 0.9 \\
\hline Nuclear Fuel Cycle $^{2}$ & 0.37 & - & - & - & - & 0.37 & 7 \\
\hline $\begin{array}{l}\text { Catalysts, Chemicals, } \\
\text { Filters }\end{array}$ & - & 0.15 & - & - & - & 0.15 & 2.8 \\
\hline $\begin{array}{l}\text { Total Cost (w/o Electricity or } \\
\text { Water) }\end{array}$ & 0.41 & 0.15 & - & 0.01 & - & 0.57 & 11 \\
\hline \multicolumn{8}{|l|}{ Utilities and Feed } \\
\hline Electricity Generated $^{3}$ & - & - & -0.65 & - & - & -0.65 & - \\
\hline Electricity Consumed $^{3}$ & 0.34 & 1.47 & 0.01 & 0.02 & - & 1.84 & - \\
\hline Electricity Imported $^{3}$ & - & - & - & - & - & 1.19 & 22 \\
\hline Water Consumption & - & 0.02 & 0.01 & - & - & 0.04 & 0.7 \\
\hline Total Utilities and Feed & 0.34 & 1.49 & -0.62 & 0.02 & - & 1.23 & 23 \\
\hline $\begin{array}{l}\text { Total Variable Operating } \\
\text { Costs }\end{array}$ & 0.75 & 1.63 & -0.62 & 0.03 & - & 1.79 & 34 \\
\hline Total O\&M Costs & 0.86 & 1.71 & -0.61 & 0.06 & 0.47 & 2.47 & 46 \\
\hline Subtotal $\mathrm{H}_{2}$ Cost & 2.40 & 2.44 & -0.41 & 0.55 & 0.68 & 5.66 & 106 \\
\hline $\mathrm{O}_{2}$ By-product Credit ${ }^{4}$ & - & -0.32 & - & - & - & -0.32 & -6 \\
\hline Final $\mathrm{H}_{2}$ Price & 2.40 & 2.12 & -0.41 & 0.55 & 0.68 & 5.34 & 100 \\
\hline$\%$ of price & 45 & 40 & -8 & 10 & 13 & 100 & - \\
\hline
\end{tabular}

Notes:

${ }^{1}$ For initial capital cost this is the Indirect (Owners' and Other) Costs; for replacement capital this is the sum of globally applied $1 / 2 \%$ unplanned replacement capital and charge for $15 \%$ working capital

2 levelized cost over plant lifetime, based on $\$ 100$ per PBMR fuel sphere in 2008 escalated at $1 / 2 \% / y r$

3 levelized cost over plant lifetime, based on $60 \$ / \mathrm{MW}_{\mathrm{e}}-\mathrm{hr}$ in 2008 escalated at $1 \% / \mathrm{yr}$

${ }^{4}$ assigned arbitrarily to the HPS 
Table 7-9 H2A Calculation Factors

\begin{tabular}{|l|c|}
\hline After Tax Real IRR & $10.0 \%$ \\
\hline Pre Tax Real IRR & $13.8 \%$ \\
\hline After Tax Real Capital Recovery Factor & 0.102 \\
\hline Total Real Fixed Charge Rate & 0.139 \\
\hline
\end{tabular}

Two useful further analyses are the comparison of this calculated price for hydrogen with calculations on the same bases of hydrogen production from the baseline alternative technologies, as detailed in Section 7.2 and evaluation of the sensitivities of this price to the most significant driving factors comprising it. The sensitivities are addressed in section 7.4.

Figure 7-3 shows the comparison of HyS hydrogen cost to SMR hydrogen and to grid power electrolysis for the range of natural gas and electricity prices. For SMR the natural gas, electricity and $\mathrm{CO}_{2}$ costs are escalated at $2 \%, 1 \%$ and $1 \%$ respectively. For the $\mathrm{HyS}$ and electrolysis the cost of electricity is escalated at $1 \%$. (Note that the superimposed ordinate axes scales for natural gas and electricity are not intended to imply a relationship between the two.)

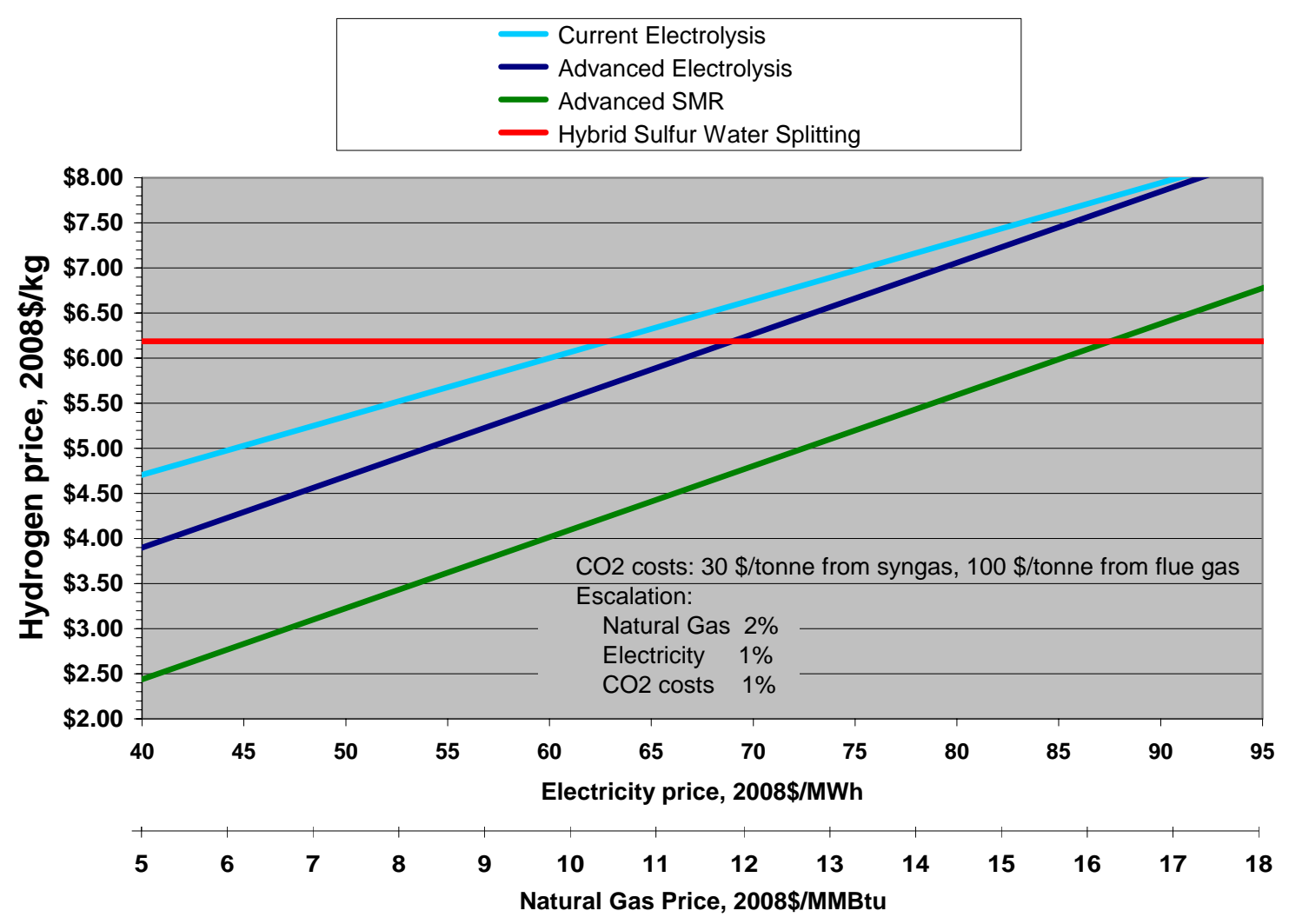

Figure 7-3 HyS Hydrogen Price and Baselines, All with Escalation 
As included earlier, reference values for recent historical prices of natural gas are \$8/MMBtu and for industrial electricity $\$ 60 / \mathrm{MW}_{\mathrm{e}}-\mathrm{hr}$. Higher values for comparison might be the spot price ranges as of this writing which are $\$ 9.25$ to $\$ 10 / \mathrm{MMBtu}$ and $\$ 75$ to $\$ 90 / \mathrm{MW}_{\mathrm{e}}-\mathrm{hr}[31$ ] Natural gas prices reached \$13/MMBtu recently (June 2008), although the price of crude oil peaked then as well. Also, because of seasonal variation the spot price of natural gas is not an indicator of the annual average.

At presently estimated costs, according to the H2A model with the assumptions and groundrules as stated in this report, the hybrid sulfur nuclear water splitting plant competes with natural gas at a gas price of $\$ 16 / \mathrm{MMBtu}$ and with electrolysis at between $\$ 60$ and $\$ 70 / \mathrm{MW}_{\mathrm{e}}-\mathrm{hr}$. The competitive advantage over electrolysis depends on the future efficiency and costs for conventional alkaline electrolysis that one expects, but even for the most extreme future electrolysis case, the hybrid sulfur matches hydrogen price for an electricity cost of $\$ 90 / \mathrm{MW}_{\mathrm{e}}-\mathrm{hr}$ in 2008 dollars escalated at $1 \%$, which is not an unreasonable expectation.

\subsection{SENSITIVITY ANALYSIS}

The effects on hydrogen price were calculated for uncertainties in major parts of the hybrid sulfur plant costs. These are divided into two groups - capital cost factors and other factors. The H2A computer program was run for variations as shown in Table 7-10 and the resulting sensitivities of the cost are presented in the two "tornado" plots in Figure 7-4 and Figure 7-5.

While the sensitivity factors are arbitrary, they are chosen with some engineering judgment and reasonable anticipation of future trends. The resulting figures indicate that, after IRR, the electrolyzer cost and the process efficiency are the factors to which hydrogen cost is most sensitive. 
Table 7-10 Sensitivity Input Variables

\begin{tabular}{|c|c|}
\hline Capital Cost Factors & \\
\hline NHSS Overall Initial Cost & $\pm 30 \%$ \\
\hline Acid Decomposer Cost & $\pm 50 \%$ \\
\hline Electrolyzer Cost & $\pm 50 \%$ \\
\hline IHX Replacement Cost & $\pm 50 \%$ \\
\hline IHX Renewal Period & $20,8 \mathrm{yr}$, none \\
\hline Electrolyzer Renewal Cost & $-25 \%,+75 \%$ \\
\hline Acid Decomposer Replacement Cost & $\pm 50 \%$ \\
\hline Decomposer Renewal Period & $10,5 \mathrm{yr}$, none \\
\hline Other Cost Factors & $8 \%, 10 \%, 15 \%$ \\
\hline IRR & $48 \%, 43 \%, 38 \%$ \\
\hline Hydrogen Production Efficiency $*$ & $-10 \%,+25 \%$ \\
\hline Cost of Electric Power Imported & $0 \%, 1 \%, 2 \%$ \\
\hline Electric Power Cost Escalation & $0, \$ 20 / \mathrm{MT}, \$ 50 / \mathrm{MT}$ \\
\hline Oxygen Byproduct Credit & $80 \%, 94 \%, 97 \%$ \\
\hline Plant Capacity Factor & \\
\hline
\end{tabular}

* First order effect: varying throughput without resizing plant 


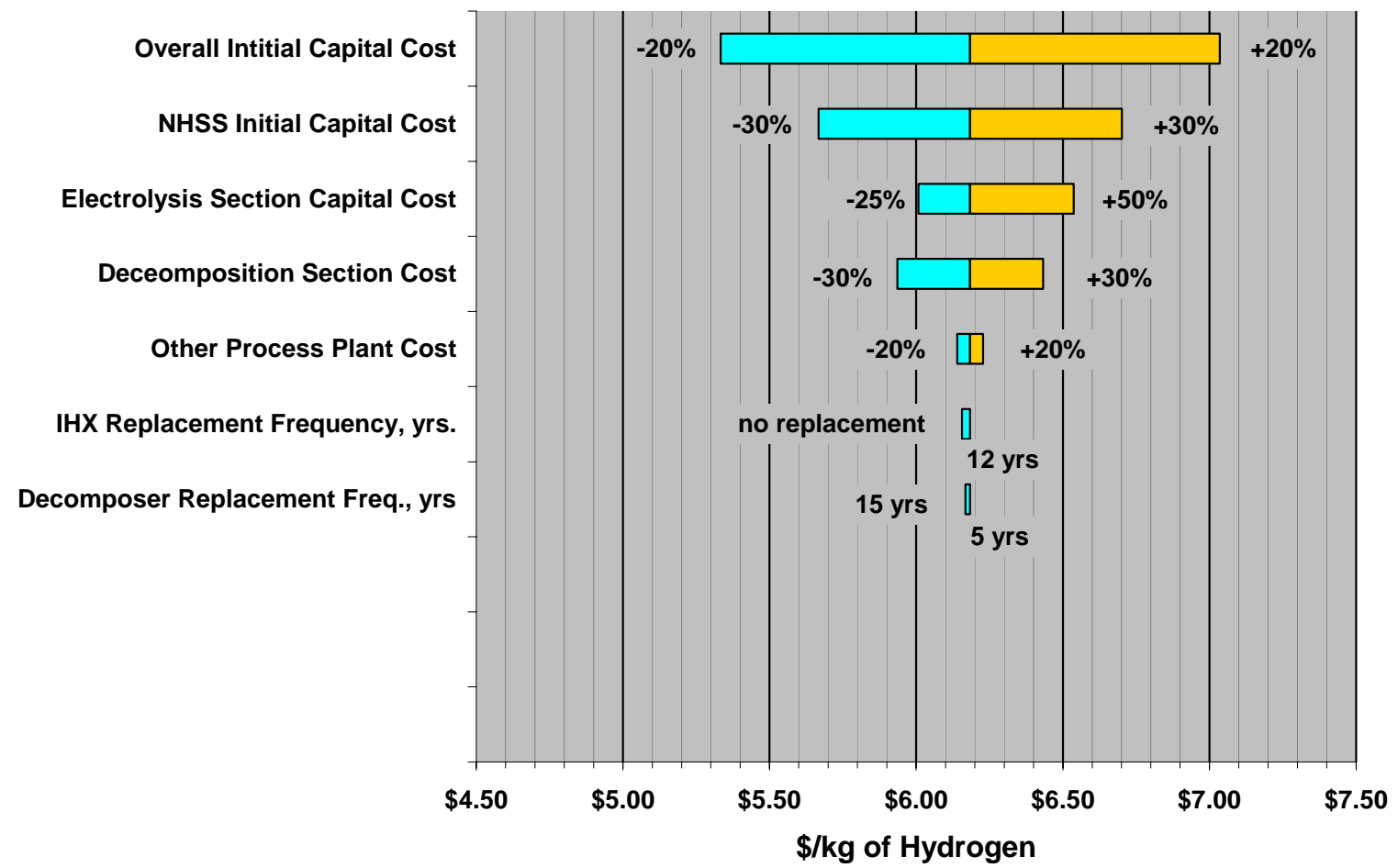

Figure 7-4 Tornado Chart for HyS Capital Costs 


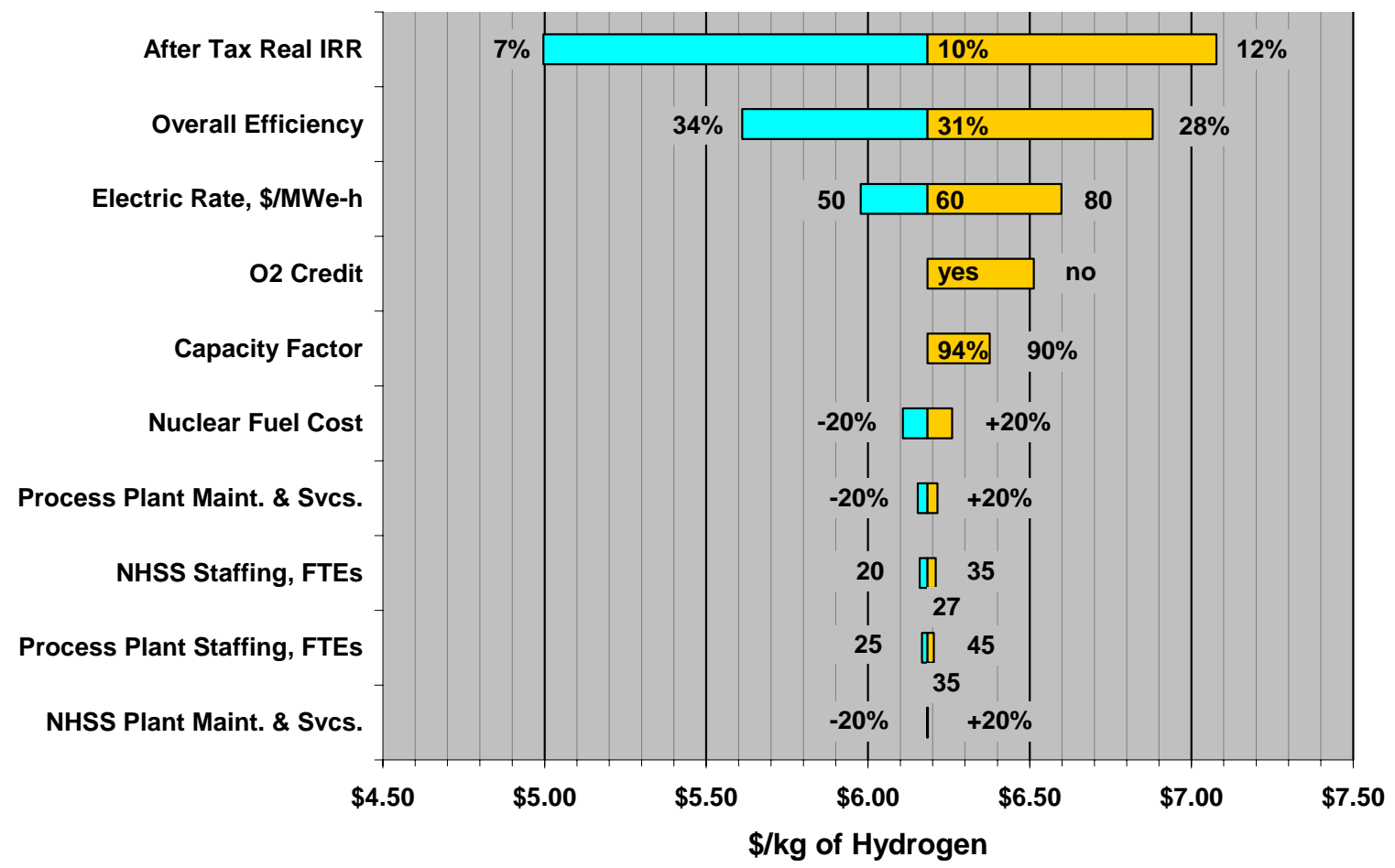

Figure 7-5 Tornado Chart for HyS Other Than Capital Costs 


\subsection{REFERENCES}

1 Brecher LE, Wu CK. Electrolytic decomposition of water. Westinghouse Electric Corp., US Patent No. 3888750, 1975.

2 Farbman GH. The conceptual design of an integrated nuclear-hydrogen production plant using the sulfur cycle water decomposition system. NASA Contractor Report, NASA-CR134976, 1976.

3 Lu PWT, Ammon RL, Parker GH. A study on the electrolysis of sulfur dioxide and water for the sulfur cycle hydrogen production process. NASA Contractor Report, NASA-CR$163517,1980$.

4 Parker GH. Solar thermal hydrogen production process. Final Report from Westinghouse Electric Corp. to US DOE, DOE/ET/20608-1, 1983.

5 Brecher LE, Spewock S, Warde CJ. The Westinghouse Sulfur Cycle for the thermochemical decomposition of water. Int J Hydrogen Energy 1977;2(1):7-15.

6 Bard AJ, Parsons R, Jordan J. Standard Potentials in Aqueous Solutions. New York: Marcel-Dekker, 1985.

7 Bratsch SG. Standard Electrode Potentials and Temperature Coefficients in Water at 298.15K. J Phys Chem Ref Data 1989;18:1-21.

8 International Nuclear Energy Research Initiative, 2006 Annual Report. DOE/NE-131. Washington, DC: United States Department of Energy, 2007. p. 113.

9 Parma EJ, Vernon ME, Gelbard F, Moore RC, Stone HBJ, Pickard PS. Modeling the Sulfuric Acid Decomposition Section for Hydrogen Production. Proc, 2007 Int Topical Mtg on Safety and Technol of Nucl Hydrogen Prodn, Control, \& Mgmt, Boston, MA, Jun 24-28, 2007: 154-160.

$10 \mathrm{Lu}$ PWT, Garcia ER, Ammon RL. Recent developments in the technology of sulphur dioxide depolarized electrolysis. J Appl Electrochem 1981;11:347-355.

11 Norsk Hydro Electrolysers AS. High Pressure Electrolysers: 10-60 Nm3/h. http://www4.hydro.com/electrolysers/en/products/range/high_pressure_electrolyser/, February 25, 2008. 
12 Norsk Hydro Electrolysers AS. Product development-the shape of things to come. http://www4.hydro.com/electrolysers/en/products/product_development/, February 25, 2008.

13 Gorensek MB, Summers WA. Hybrid sulfur flowsheets using PEM electrolysis and a bayonet decomposition reactor. Int J Hydrogen Energy 2009;34(9):4097-4114.

14. Greyvenstein R. Email to Gorensek MB. Subject: RE: Draft of Chapter 3 from PBMRNHSS report for your comments/suggestions/changes, etc., May 25, 2008, 5:54 PM.

15. Bolthrunis CO, Lahoda EJ, Brabazon E. NGNP and Hydrogen Production Preconceptual Design Report, NGNP-07-RPT-001; Rev 0, May 2007, Section 7: Hydrogen Production System, Rev. 0, Appendix C.

16. Wang P, Anderko A, Springer RD, Young RD. Modeling phase equilibria and speciation in mixed-solvent electrolyte systems: II. Liquid-liquid equilibria and properties of associating electrolyte solutions J Molec Liquids 2006;125:37-44.

17. Miles FD, Fenton J. The solubility of sulfur dioxide in sulfuric acid. J Chem Soc 1920;117:59-61.

18. Kuznetsov DA. Study of the equilibrium pressures of sulfur dioxide over water and aqueous solutions of sulfuric acid (transl.). Zh Khim Prom (USSR.) 1941;18(22):3-7.

19. Miles FD, Carson T. Solubility of sulfur dioxide in fuming sulfuric acid. J Chem Soc 1946:786-90.

20. Maass CE, Maass O. Sulfur dioxide and its aqueous solutions. I. Analytical methods, vapor density and vapor pressure of sulfur dioxide. Vapor pressure and concentrations of the solutions. J Am Chem Soc 1928;50(5):1352-1368.

21. Spall BC. Phase equilibriums in the system sulfur dioxide-water from $25-300^{\circ}$. Can $\mathrm{J}$ Chem Engr 1963;41:79-83.

22. van Berkum JG, Diepen GAM. Phase equilibriums in sulfur dioxide + water: the sulfur dioxide gas hydrate, two liquid phases, and the gas phase in the temperature range 273 to 400 $\mathrm{K}$ and at pressures up to $400 \mathrm{MPa}$. J Chem Thermodynamics 1979;11:317-334.

23. Staser J, Ramasamy RP, Sivasubramanian P, Weidner JW. Effect of Water on the Electrochemical Oxidation of Gas-Phase $\mathrm{SO}_{2}$ in a PEM Electrolyzer for $\mathrm{H}_{2}$ Production. Electrochem Solid-State Lett 2007;10:E17-E19.

24. Areva NP. Olkiluoto 3, EPR - facts and figures. http://www.ol3.arevanp.com/project/facts.htm. May 29, 2008. 
25 "NGNP and Hydrogen Production Pre-conceptual Design Report", Westinghouse Electric Company LLC, May 2007.

26 "NGNP Conceptual Design Study: IHX and Heat Transport System", Westinghouse Electric Company LLC, April 2008.

27 http://www.hydrogen.energy.gov/h2a analysis.html.

28

"04D_Future_Central_Hydrogen_Production_from_Natural_Gas_with_CO2_Sequestration version_2.0.1.xls", developed by Mike Rutkowski, Parsons Corporation, 14AUG05, from [27] website.

29 Economic Indicators, Chemical Engineering, MAY08.

30 2007: range $6.11 \$ /$ thou cu ft to $8.40 \$ /$ thou cu ft, average $7.57 \$ /$ thou cu ft, http://tonto.eia.doe.gov/dnav/ng/hist/n3035us3m.htm.

$31 \mathrm{http}: / /$ www.bloomberg.com/energy/, 31JUL08.

32 http://www.electrolysers.com/.

33 http://www.technologyreview.com/BizTech/wtr_16523,295,p1.html.

34 01D_Current_Central_Hydrogen_Production_from_Grid_Electrolysis_version_2.0.1.xls" and

“02D_Future_Central_Hydrogen_Production_from_Grid_Electrolysis_version_2.0.1.xls", developed by Johanna Ivy Levene, NREL, 08NOV05, from [27] website.

35 Offer 106602, Norsk Hydro Electrolyzers AS, 08AUG02.

36 Levene, J., and T. Ramsden, "Summary of Electrolytic Hydrogen Production", NREL/MP-560-41099, DRAFT dated January 2007.

37 11. National average for industrial sales in 2006: 61.6 \$/MWh, http://www.eia.doe.gov/cneaf/electricity/wholesale/wholesale.html. 


\subsection{APPENDIX - NUCLEAR HYDROGEN PRODUCTION WITH THE PBMR}

\subsection{NUCLEAR ENERGY SOURCE}

The PBMR matches the process heat requirements of several important, large-scale applications, notably hydrogen production, with a delivery temperature up to $900^{\circ} \mathrm{C}$ and thermal capacity up to $500 \mathrm{MW}_{\text {th }}$.

Westinghouse Electric, PBMR (Pty) Ltd. and Shaw are collaborating to develop nuclear hydrogen production solutions using the PBMR because, in addition to the excellent temperature and thermal capacity match, its inherent safety allows sitting the reactor in close proximity to the hydrogen plant. On-line reactor refueling also reduces down time.

In the US, the HTGR is being advanced by means of the NGNP Project. This project is directed at building an HTGR which will be used for process heat, cogeneration and hydrogen production. Three hydrogen-from-water processes (High Temperature Steam Electrolysis and two thermochemical cycles - Sulfur-Iodine and Hybrid Sulfur) that could be used in the NGNP are being developed by the NHI.

The PBMR-based team (including PBMR, Westinghouse, Shaw and others) has selected the HyS hydrogen process for priority development. The team is cooperating with the NHIsupported effort at SRNL and the South African government hydrogen supported effort at North-West University to bring this technology to commercial readiness. The deployment date is targeted for the 2018 timeframe.

The HyS process uses both thermal and electrical energy from a PBMR to produce hydrogen and oxygen from water. The thermal energy is transported from the nuclear reactor by helium and is transferred via an intermediate heat exchange loop to a second helium stream. The thermal energy from the intermediate loop is used to decompose sulfuric acid $\left(\mathrm{H}_{2} \mathrm{SO}_{4}\right)$ into $\mathrm{SO}_{2}$, oxygen, and water at $700^{\circ} \mathrm{C}$ to $900^{\circ} \mathrm{C}$ :

$$
\mathrm{H}_{2} \mathrm{SO}_{4} \leftrightarrow \mathrm{H}_{2} \mathrm{O}+\mathrm{SO}_{2}+1 / 2 \mathrm{O}_{2}
$$

Oxygen is then removed and the water and $\mathrm{SO}_{2}$ are electrolyzed to generate hydrogen gas and sulfuric acid at $100^{\circ} \mathrm{C}$ :

$$
2 \mathrm{H}_{2} \mathrm{O}+\mathrm{SO}_{2} \rightarrow \mathrm{H}_{2} \mathrm{SO}_{4}+\mathrm{H}_{2}
$$

The sulfuric acid is recycled back into decomposition reactor. 
PBMR is also working with Shaw and others to evaluate interim hydrogen production technologies that need large amounts of high temperature process heat. Chief among these is Steam Methane Reforming (SMR), where the PBMR process heat displaces natural gas used for firing the reformer and generating steam for a net natural gas savings of about $25 \%$. In addition, the expensive to capture flue-gas $\mathrm{CO}_{2}$ is eliminated.

\subsubsection{Substitute Capital for Natural Gas}

Nuclear hydrogen production will require a substantial initial capital investment. This will be offset by long-term savings in feedstock and reduced emissions that come from combustion of natural gas in present hydrogen production (by steam methane reforming). After the initial investment is made, operating costs will be stable, predictable, and much less vulnerable to energy cost and natural gas availability.

\subsubsection{Eliminate $\mathrm{CO}_{2}$ Emissions}

A future challenge for all manufacturers and energy producers will be stewardship of the environment. They will face possible restrictions on $\mathrm{CO}_{2}$ emissions or carbon emission taxes. These will have a major impact on the cost of hydrogen production from hydrocarbons. Nuclear hydrogen generated from water, on the other hand, avoids $\mathrm{CO}_{2}$ emissions entirely. It is both environmentally responsible and avoids the economic burdens of $\mathrm{CO}_{2}$ emissions.

\subsubsection{Petroleum and Global Warming}

Nuclear hydrogen will favorably impact the net greenhouse gas emissions of the petroleumbased motor vehicle segment, which is a prime target for addressing global warming. Large quantities of hydrogen are used in oil refining, and so $\mathrm{CO}_{2}$ emissions will decline to the degree natural gas is displaced by nuclear heat for hydrogen production.

\subsubsection{Clean Coal Conversion}

Integrating nuclear hydrogen production with conversion of coal to synthetic natural gas (SNG) or liquid fuels offers several major advantages. Hydrogen is usually made from a carbon fuel and water, thereby generating $\mathrm{CO}_{2}$. Generating hydrogen from nuclear energy and water eliminates about half of the facilities and capital investment for a clean coal conversion plant. Twice as much premium hydrocarbon fuel can be produced per ton of coal mined and half the $\mathrm{CO}_{2}$ emitted per mile driven or Btu used.

\subsubsection{Summary}

Global increased energy demand, increased cost of natural gas and petroleum, energy security concerns and environmental degradation are leading to heightened interest in using nuclear energy and hydrogen to extend the life of existing hydrocarbon reserves. PBMR based nuclear hydrogen production offers the promise of a sustainable, clean, safe and economic hydrogen supply. 


\subsection{PEBBLE BED MODULAR REACTOR}

\subsubsection{How the PBMR Works}

The PBMR is a helium-cooled, graphite-moderated, High Temperature Reactor (HTR). The PBMR has a 27-m (88-ft) high vertical steel Reactor Pressure Vessel (RPV) with an inner diameter of about $6.2 \mathrm{~m}(20 \mathrm{ft})$. The RPV contains and supports a metallic core barrel. The core barrel, in turn, supports the annular pebble fuel core, which is located in the space between a central and outer graphite reflector. Vertical borings in these reflectors are provided for the reactivity control elements. Two diverse reactivity control systems are provided for shutting the reactor down. One of the systems is 24 control rods in the outer reflector, while the other consists of small absorber spheres which are dropped into eight borings in the central reflector.

The PBMR uses particles of enriched uranium dioxide coated with silicon carbide and pyrolytic carbon. The particles are encased in graphite to form a fuel sphere or pebble about the size of a billiard ball. Helium is used as the coolant and energy transfer medium, to drive a closed cycle gas turbine-compressor and generator system. When fully loaded, the core would contain approximately 450,000 fuel spheres.

Through 2008, the focus of PBMR development in South Africa was on a 400 MWt Brayton cycle design. The main power system for the Brayton cycle power generation application is shown in Figure 9-1 (3D view) and Figure 9-2 (schematic 2D diagram). 


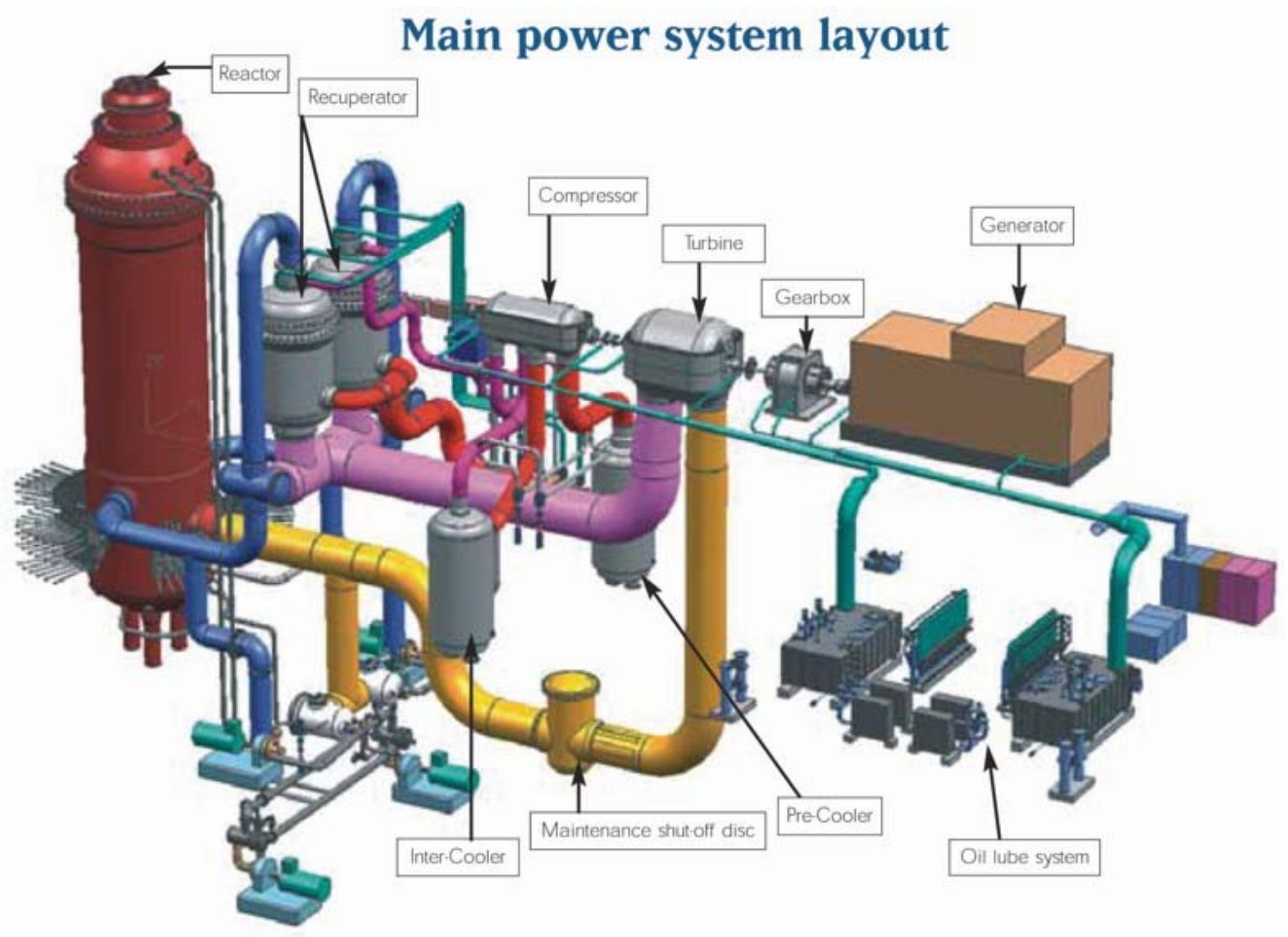

Figure 9-1 Main power system layout 


\section{Main power system schematic diagram}

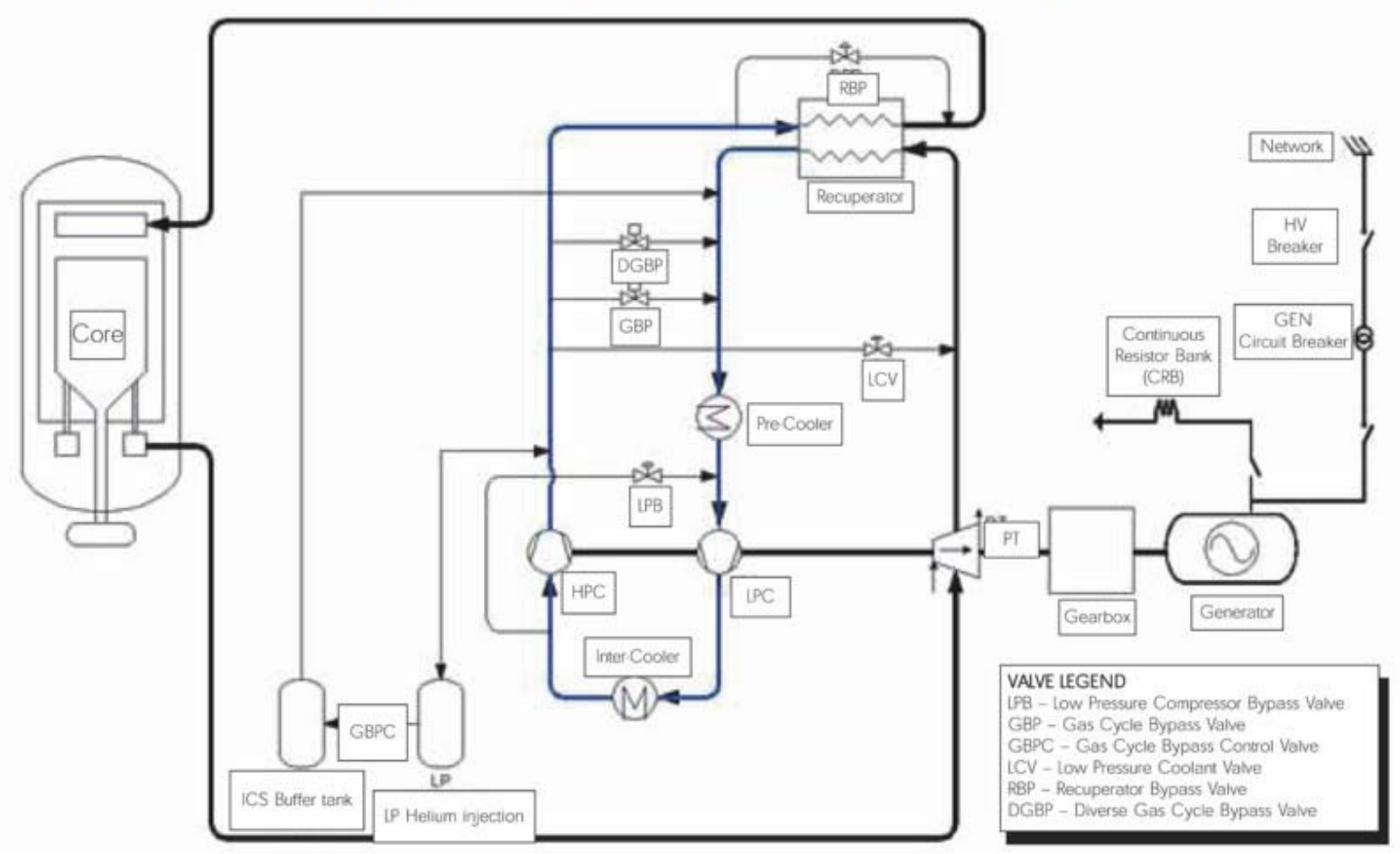

\section{Figure 9-2 Main power system schematic diagram}

To remove the heat generated by the nuclear fission reaction, helium coolant enters the reactor vessel at a temperature of about $500^{\circ} \mathrm{C}\left(932^{\circ} \mathrm{F}\right)$ and a pressure of $9 \mathrm{MPa}$ or 1,323 pounds per square inch (psi). The gas flows down between the hot fuel spheres, after which it leaves the bottom of the vessel having been heated to a temperature of about $900^{\circ} \mathrm{C}$ $\left(1652^{\circ} \mathrm{F}\right)$. The hot gas then enters the turbine, which is mechanically connected to the generator through a speed-reduction gearbox on one side and the gas compressors on the other side. The coolant leaves the turbine at about $500^{\circ} \mathrm{C}\left(932^{\circ} \mathrm{F}\right)$ and $2.6 \mathrm{MPa}(377 \mathrm{psi})$, after which it is cooled, recompressed, reheated and returned to the reactor vessel.

The thermodynamic cycle used is a Brayton cycle with a water-cooled pre-cooler and intercooler. A high efficiency recuperator is used after the power turbine.

The helium, cooled in the recuperator, is passed through the pre-cooler, low pressure compressor, the intercooler and high-pressure compressor before being returned through the recuperator to the reactor core.

The power taken up by the helium in the core and the power given off in the power turbine is proportional to the helium mass flow rate for the same temperatures in the system. The mass flow rate depends on the pressure, so the power can be adjusted by changing the pressure in the system. The high-pressure and high-temperature operation of the reactor results in a relatively high thermal efficiency. While a typical light water reactor has a thermal efficiency (electrical power output/thermal heat input) of approximately $33 \%$, an efficiency of about $41 \%$ is anticipated in the basic PBMR design. 
Online re-fuelling is another key feature of the PBMR. Fresh fuel elements are added to the top of the reactor while used fuel is removed at the bottom while the reactor is at power. The aim is to operate uninterrupted for six years before the reactor is shut down for scheduled maintenance. For the demonstration module, however, a number of interim shutdowns will be required for planned evaluation of component and system performance.

Shutdown will be done by inserting the control rods. Start-up is effected by making the reactor critical, then using nuclear heat-up of the core and circulating the coolant by motoring the turbo-generator set. Heat is then removed by the pre-cooler and intercooler. At a specified temperature, the cycle becomes self-sustaining.

\subsubsection{How the PBMR Fuel Works}

PBMR fuel is based on a proven, high-quality German fuel design consisting of low enriched uranium triple-coated isotropic (LEU-TRISO) particles contained in a molded graphite sphere. A coated particle consists of a kernel of uranium dioxide surrounded by four coating layers. In the fabrication process, a solution of uranyl nitrate is dropped from small nozzles to form microspheres, which are then gelled and calcined (baked at high temperature) to produce uranium dioxide fuel "kernels". The kernels are then run through a Chemical Vapor Deposition (CVD) furnace in an argon environment at a temperature of $1,000^{\circ} \mathrm{C}\left(1,832^{\circ} \mathrm{F}\right)$, in which layers of specific chemicals can be added with extreme precision.

For PBMR fuel, the first layer deposited on the kernels is porous carbon. This is followed by a thin coating of pyrolytic carbon (a very dense form of carbon), a layer of silicon carbide (a strong refractory material), and finally, another layer of pyrolytic carbon. The porous carbon accommodates any mechanical deformation that the uranium dioxide kernel may undergo during the lifetime of the fuel, as well as gaseous fission products diffusing out of the kernel. The pyrolytic carbon and silicon carbide layers provide an impenetrable barrier designed to contain the fuel and fission products. Some 15,000 of these coated particles, now about a millimeter in diameter, are then mixed with graphite powder and a phenolic resin, and pressed into 50-mm diameter spheres. A 5-mm thick layer of pure carbon is then added to form a "non-fuel" zone, and the resulting spheres are sintered and annealed to make them hard and durable.

Finally, the spherical fuel "pebbles" are machined to a uniform diameter of $60 \mathrm{~mm}$. Each fuel pebble contains about $9 \mathrm{~g}$ of uranium. The total uranium in one fuel load is 4.1 metric tons, and the total mass of a fuel pebble is $210 \mathrm{~g}$. A schematic of fuel element design for the PBMR is shown in Figure 9-3. 


\section{FUEL ELEMENT DESIGN FDR PBMR}

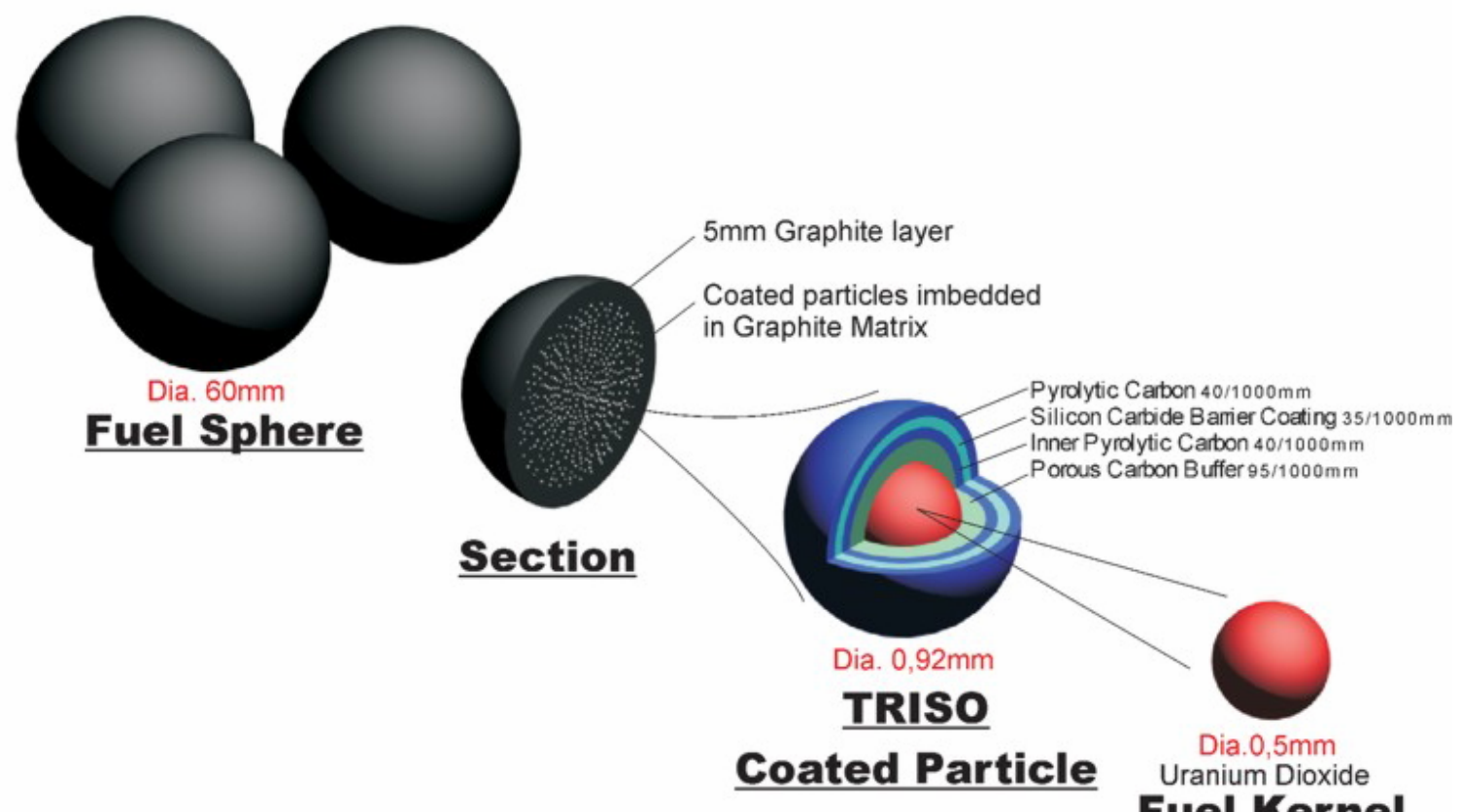

\section{Figure 9-3 Fuel element design for PBMR}

Graphite is used for the reflectors. A central reflector column is located in the center of the core and an outer reflector on the outside of the core. The fuel core is in the annulus between the outer and central reflectors. During normal operation, the PBMR core contains a load of approximately 450,000 fuel pebbles. Graphite is used in the reactor core because of its structural characteristics and its ability to slow down neutrons to the speed required for the nuclear fission reaction to take place. The core and core structures geometry used in the PBMR provide inherent characteristics which limit the peak temperature in the fuel following an accidental loss of active cooling.

The uranium-235 (U-235) isotope occurs in natural uranium at a concentration of approximately $0.7 \%$. In order to have a self-sustaining or "chain" reaction, the uranium in the PBMR pebbles is enriched to about $10 \% \mathrm{U}-235$, which is the isotope of uranium which mainly undergoes fission in the core. The reactor is continuously replenished with fresh or reusable fuel from the top, while used fuel is removed from the bottom. After each pass through the reactor core, the fuel pebbles are measured to determine the amount of fissionable material left. If a pebble still contains a usable amount of the fissile material, it is returned to the reactor at the top for a further cycle. Each cycle takes about six months.

Each pebble passes through the reactor about six times and lasts about three years before it is spent, which means that a reactor will use 15 total fuel loads in its design lifetime of 40 years. The extent to which the enriched uranium is used to the point where it is no longer of use in the core (called the "burn-up" level), is much greater in the PBMR than in conventional power reactors. The fissile material that could be extracted from spent PBMR 
fuel is extremely unattractive for proliferation purposes. This, coupled with the level of technology of coated particle fuel reprocessing, protects the PBMR fuel against the possibility of nuclear proliferation or other covert use. The fuel is transported to the spent fuel storage facility in the reactor building by means of a pneumatic fuel handling system. The spent fuel storage consists of 10 tanks, each with a diameter of $3.2 \mathrm{~m}(10.4 \mathrm{ft})$ and a height of $18 \mathrm{~m}(58.5 \mathrm{ft})$. One tank can store 600,000 pebbles. The PBMR fuel will be manufactured at the Necsa site at Pelindaba near Pretoria, using the technology established in Germany. The facility will have an initial capacity of 270,000 fuel spheres per year.

\subsubsection{The PBMR'S Safety Features}

In all existing power reactors, safety objectives are achieved by means of custom-engineered, active safety systems. In contrast, the Pebble Bed Modular Reactor (PBMR) has inherently safe features achieved by the design, the materials used, the fuel, and the physics involved. This means that, should a worst-case accident occur, no human intervention is required in the short or medium term.

Nuclear accidents are principally driven by the residual power caused by radioactive decay of fission products in the fuel after the chain reaction is stopped. If this decay heat is not removed, it will heat up the nuclear fuel until its fission product retention capability is degraded and its radioactivity is released.

In "conventional" reactors, heat removal is achieved by active cooling systems (such as pumps), which rely on the presence of a heat transfer fluid, normally water. Because of the potential for failure in these systems, they are duplicated to provide redundancy. Other systems, such as a containment building, are provided to mitigate the consequences of failure and to act as a further barrier to radioactive release. In the PBMR, the removal of the decay heat is independent of the reactor coolant conditions. The combination of the very low power density of the core (1/20th of the power density of a pressurized water reactor, PWR), and the resistance to the high temperature of fuel in billions of independent particles, underpins the superior safety characteristics of this type of reactor.

The pre- and intercoolers remove heat from the power conversion system. The secondary sides of the pre- and intercoolers are cooled with demineralized water in a closed, intermediate loop. This loop is again cooled by seawater or (should this system fail), cooling towers.

The waste heat from the Reactor Cavity Cooling System is cooled by a similar arrangement. Should the pre- or intercoolers leak, only helium can enter the intermediate loop. A pressure increase sensor would indicate such a leak.

The helium, which is used to transfer heat from the core to the power-generating gas turbines, is chemically inert. It cannot combine with other chemicals or elements and is noncombustible. Should a pipe burst, the helium will, depending on the size of the break (smaller than $8 \mathrm{~mm}$ ), be filtered and released to the atmosphere. Larger breaks will cause the rupture of a rupture panel (similar to a rupture disc). In such an event, the gas and contaminants that 
did not settle or plate out in the inside of the building will be released in a burst to the atmosphere through a dedicated pressure relief shaft. Following this release, the shaft is automatically closed. A manual backup closure system is available should the automatic closure not work.

\subsubsection{Why a core meltdown or Chernobyl-type accident is not possible}

The peak temperature that can be reached in the core of the reactor $\left(1,600^{\circ} \mathrm{C}\right.$ or $2,900^{\circ} \mathrm{F}$ under the most severe conditions) is well below the temperature that may cause damage to the fuel. This is because the radionuclides, which are the potentially harmful products of the nuclear reaction, are contained by two layers of pyrocarbon and a layer of silicon carbide, which maintain their strength and integrity at very high temperatures.

Even if there were a failure of the active systems that are designed to shut down the nuclear reaction and remove core decay heat, the reactor itself will inherently shut down and eventually cool down naturally.

Unlike the Chernobyl type of reactor, which during the accident produced more energy the hotter it became (known as "a positive temperature coefficient of reactivity), the pebble bed reactor has a strong negative temperature coefficient of reactivity which stops the chain reaction. It also cools naturally by heat transport to the environment.

The size and form of the PBMR core ensure a high surface area to volume ratio. This results in the decay heat generated after the reactor has shut itself down, being passively transmitted to the environment (via the same process that allows a cup of tea to cool down). This means that the reactor will never reach a temperature at which significant degradation of the activity retention capability of the fuel can occur. In a nutshell: the plant can never be hot enough for long enough to cause damage to the fuel.

The inherently safe design characteristics of the PBMR render obsolete the need for safety backup systems and most aspects of the off-site emergency plans required for conventional nuclear reactors. It is also fundamental to the cost reduction achieved over other nuclear designs.

Although plans related to aspects such as the transport of fuel will still be required, they will be modified to suit the specific characteristics of the fuel and the transport mode.

The reactor core concept is based on the well-tried and proven German AVR power plant, which ran for 21 years. This safe design was proven during a public and filmed plant safety test on the $22^{\text {nd }}$ of September, 1970, when the flow of coolant through the reactor core was stopped and the control rods were left withdrawn just as if the plant was in normal power generation mode. It was demonstrated that the reactor core shut itself down inherently within a few minutes. It was subsequently proven that there was no deterioration over and above the normal design failure fraction of the nuclear fuel. This proved that a reactor core meltdown was not credible, and that an inherently safe nuclear reactor design had been achieved. The graphs reported in Figure 9-4 and Figure 9-5 show how PBMR fuel behaves under extended 
periods of high temperature and how temperatures are affected by "loss of coolant" type events.

\section{Fuel Performance}

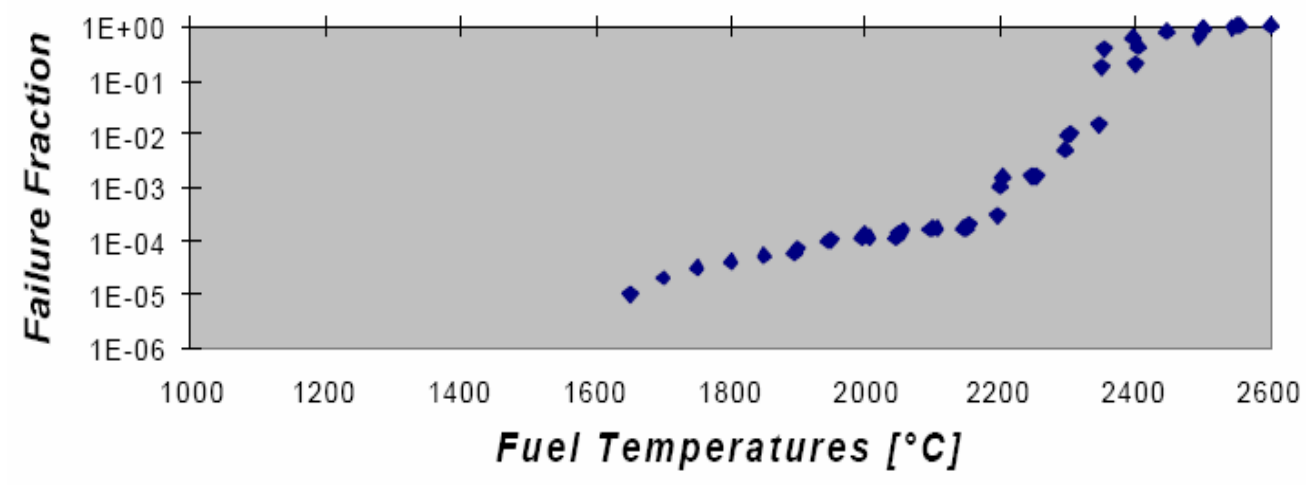

Figure 9-4 Performance of PBMR fuel under extended periods at high temperatures

\section{Loss of Coolant Event}

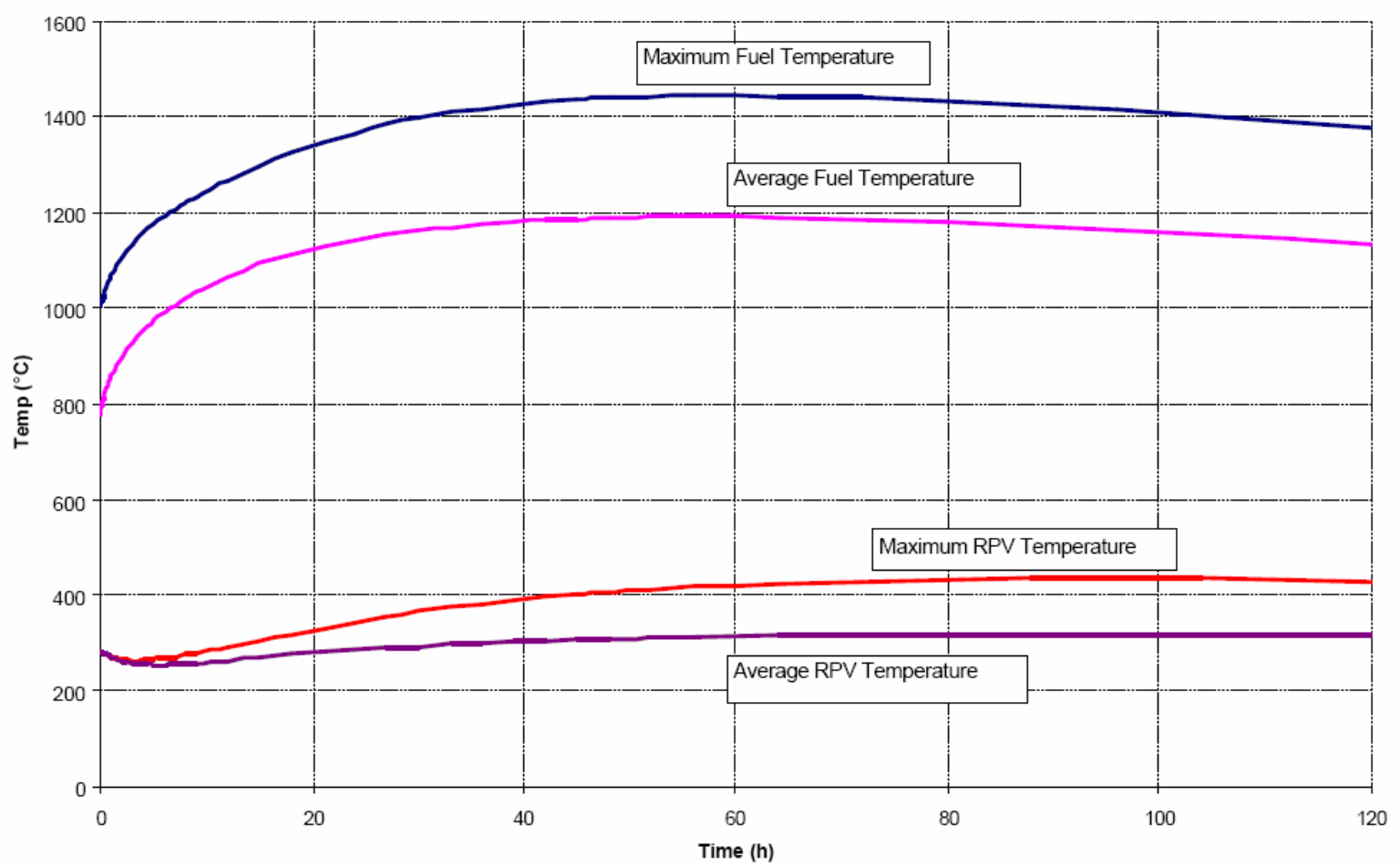

Figure 9-5 Temperature of the hottest part of the fuel and overall average after a total loss of coolant 
The PBMR module building, which comprises the entire structure that houses the power plant (excluding the generator), is designed to withstand significant external forces such as aircraft impacts, tornadoes or explosions due to sabotage. Above ground level, the thickness of the reinforced concrete roof and walls of this structure is $1 \mathrm{~m}$. Within the module building is the reinforced concrete containment or citadel that encloses the reactor pressure vessel and the power conversion unit. The thickness of the walls surrounding the reactor pressure vessel is $2.2 \mathrm{~m}$. The power conversion unit comprises the high and low pressure compressor unit, and the power turbine, gearbox, generator, recuperator and coolers.

\subsubsection{How the PBMR Project Came About}

Almost $90 \%$ of South Africa's electricity is generated in coal-fired power stations, with one large nuclear station (Koeberg near Cape Town) providing about 5\%. A further 5\% is provided by hydroelectric and pumped storage schemes, as well as open-cycle gas turbines. There are few, if any, new economic hydro sites in South Africa that could be developed to deliver significant amounts of power. The country's natural gas resources are also too limited to qualify as a viable option for bulk power generation. In view of this, the South African power utility Eskom has been investigating pebble bed technology since 1993 as part of its Integrated Electricity Planning process. These investigations, which included an evaluation of the technical performance and economic merits of the project, concluded that PBMR technology should be considered as a possible option for future South African electricity supply, as it offered a cost-effective option with short construction lead times. In 1995, Eskom commissioned a pre-feasibility study, followed by a techno-economic study in 1997. These studies showed considerable technical and commercial merit for the PBMR technology as a future source of base load energy in South Africa. In 1999, Eskom acquired a license from HTR GmbH to further develop the technology and exploit it for its own use. By mid-1999, the project had progressed to a full-scale engineering design phase. In 2000, a PBMR company was formed between Eskom, the Industrial Development Corporation of South Africa (IDC), British Nuclear Fuels, Ltd. (BNFL) and the US utility Exelon to build and market PBMR-based power plants. In April 2002, Exelon decided not to invest further in the development of PBMR technology and rather focus on its core business of operating power generation plants and brokering power sales.

The feasibility study and associated work, which was completed at the end of 2002, found that the technology was viable. It found that PBMR power plants would represent the lowest levelized cost option in 11 of 14 major markets analyzed, while being competitive in the remaining three. Since the technology has not previously been commercialized, the intention is to build and operate a single module at Koeberg to serve as a demonstration plant and a launch platform for local and international sales; and a fuel plant at Pelindaba near Pretoria.

Successful completion of the demonstration phase will be followed by commercialization, with Eskom earmarked to be the first customer. To this end, a comprehensive Environmental Impact Assessment (EIA) was conducted for the project, followed by the issuing of a positive Record of Decision (RoD) on the EIA by the Director General (DG) of the Department of 
Environmental Affairs and Tourism (DEAT). The 30-month EIA process included extensive public participation and extended periods for comment during the scoping and EIA phases. However, the anti-nuclear activist group Earthlife Africa filed an application to have the RoD overturned. In January 2005, the Cape High court ruled in favor of Earthlife Africa, and set aside the RoD. The judge ruled that the DG has to allow Earthlife Africa and other stakeholders to make written submissions, which the DG has to consider before making a new decision. The judge added, however, that it was clear from the evidence on record that the DG's decision was preceded by a protracted process, involving public participation on a wide scale and that, by and large, the "process was conducted in a manner that was thorough and fair". The court ruling and design changes to the PBMR reactor which allowed for an increase in the nominal thermal output of the demonstration reactor from 302 to $400 \mathrm{MW}_{\text {th }}$, prompted Eskom to enter into a new EIA process for the demonstration reactor project. To this end, a revised final scoping report was made available to the public in January 2007. The Minister of Environmental Affairs and Tourism upheld the positive RoD for the pilot fuel plant EIA. This would, subject to certain conditions, permit the construction of a pilot fuel plant on receipt of a nuclear authorization from the National Nuclear Regulator (NNR). The Minister's decision covered the establishment of a fuel manufacturing plant at Pelindaba; the storage, handling and process facilities for the raw materials and fuels; the transport of raw material from Durban to Pelindaba and the transport of manufactured fuel from Pelindaba to Koeberg in the Western Cape.

Considerable progress has also been made in the preparation of the Safety Analysis Report (SAR) that would underpin the application for a construction license from the South African National Nuclear Regulator for the fuel plant and demonstration reactor.

In January 2006, the US nuclear company Westinghouse took over the $15 \%$ share previously held by BNFL. The share transfer was part of BNFL's restructuring process and the UK government's decision to sell Westinghouse (Westinghouse was previously wholly-owned by BNFL). Westinghouse is the world's pioneering nuclear power company and a leading supplier of nuclear plant projects and technologies to utilities throughout the world. It is also a world leader in PWR technology, with its AP-1000 design.

Over the past few years, the South African Government allocated significant funding to the PBMR project. This enabled PBMR to secure the contracts for the development of key components such as the turbomachinery (being developed by Mitsubishi Heavy Industries of Japan), a Helium Test Facility (HTF) at Pelindaba (allocated to the South African company Powertech IST), as well as high-pressure and high-temperature test facilities in Potchefstroom near Johannesburg.

Further government support came from the South African Minister of Public Enterprises, Mr. Alec Erwin, who stated an intent to eventually produce $4,000 \mathrm{MW}_{\mathrm{e}}$ to $5,000 \mathrm{MW}_{\mathrm{e}}$ of power from pebble bed reactors in South Africa. This equates to between 24 and 30 PBMR reactors of $165 \mathrm{MW}_{\mathrm{e}}$ each. Mr. Erwin said the PBMR would place the country at the forefront of energy technology. Today, Pebble Bed Modular Reactor (Pty) Ltd has the largest nuclear reactor design team in the world. In addition to the core team of some 700 people at the PBMR head-office in Centurion near Pretoria, more than 1,000 people at universities, private 
companies and research institutes are involved with the project. Around the world, scientists and governments are looking to South Africa with great interest to see how the local nuclear reactor developments unfold.

\subsubsection{The Pebble Bed Evolution}

The PBMR is based on the design developed as part of an extensive HTR program in Germany. The Germans researched HTRs, and built a $15-\mathrm{MW}_{\mathrm{e}}\left(40-\mathrm{MW}_{\text {th }}\right)$ AVR research reactor at the nuclear research centre in Jülich. It was planned, constructed and operated as an experimental reactor on an industrial scale, and was intended to furnish an originally German contribution to the development of economic nuclear power on the basis of first-of-a-kind technology. The reactor operated from 1966 to 1988, when it was decommissioned due to political considerations and because it had fulfilled all planned research experiments.

The main feature of the AVR was a high coolant temperature to allow the generation of steam conditions and correspondingly high plant efficiencies usually reached in modern fossil-fuelled steam-power plants. The high steam temperatures were possible due to the use of ceramic fuel and the graphite fuel structure. In HTRs, such as the PBMR, graphite is also the moderator. Spherical fuel elements were used and fuelling was done with the reactor in operation. The AVR was used to test different designs of fuels, fuel loading systems and safety systems. Despite the test programs and being a first prototype, it produced power for $70 \%$ of its life. During its 21 years of operation, the design proved the superior behavior of the coated particle concept, the favorable safety characteristics of the core, and even fulfilled the safety requirements listed today for future reactors in terms of control of improbable events.

The results of various tests performed on the reactor and operational records assist in the validation of numerous analyses performed for the design and safety demonstration of the PBMR. Design changes made to the AVR resulting from operating experience were incorporated in the design of the 300- $\mathrm{MW}_{\mathrm{e}}\left(750-\mathrm{MW}_{\mathrm{th}}\right)$ Thorium High Temperature Reactor (THTR), which operated between 1985 and 1988.

The THTR was a first-of-its-kind production plant intended to demonstrate the viability of the different subsystem hardware designs, with specific emphasis on plant availability and maintainability. To this end, the design concentrated on building a plant with a lifetime of 40 years and an availability of $80 \%$ to $90 \%$. The THTR-300 was going to be the front-runner of a commercial plant, namely the HTR-500. Although both the AVR and the THTR-300 were pebble bed reactors, there were fundamental engineering differences because of the differences in size. The THTR had a reinforced concrete pressure vessel, a much larger core diameter $(2.5 \mathrm{~m}$ to $5 \mathrm{~m})$, shutdown rods in the reflector and shutdown rods in the pebble core. These changes were largely driven by the presumed need for larger reactor power levels. The concrete pressure vessel led to difficulties in insulation of the low temperature concrete (limit $60^{\circ} \mathrm{C}$ or $\left.140^{\circ} \mathrm{F}\right)$ from the high temperature gases $\left(650^{\circ} \mathrm{C}\right.$ or $\left.1,202^{\circ} \mathrm{F}\right)$. In addition, the in-core shutdown rods caused damage to fuel elements because of the need to insert the rods into the pebble bed by force during the initial testing period. The resulting high scrap-level in the fuel system, combined with too-high helium flows, led to initially low availability of the fuel 
handling system. Despite these and other minor technical deficiencies, the THTR-300 achieved the following milestones:

- first nuclear power on the $6^{\text {th }}$ of September, 1985;

- first power into the grid on the $16^{\text {th }}$ of November, 1985;

- $100 \%$ power performance on the $23^{\text {rd }}$ of September, 1986;

- |hand-off to the utilities' consortium (HKG) on the $1^{\text {st }}$ of June, 1987.

Based on the experience gained from the AVR and the THTR, two German-based groups developed further pebble bed reactor designs ranging from high power reactors mainly developed by ABB (Asea Brown Boveri), to the modular inherently safe Modul design of Siemens/Interatom. These two groups later combined to form Hochtemperatur Reaktorbau G.m.b.H. Siemens was in the process of negotiating orders for several reactors from the then East German government, the USSR and a large German chemical company when, in 1989, the Berlin wall fell. As a result, all the potential buyers broke off negotiations. Siemens subsequently decided to stop further work. At the same time, the West German government came under pressure to close existing nuclear plants. It was easier to close down the HTR research reactors, which had no impact on the electricity supply to Germany, than existing commercial nuclear power stations. In the years that followed, the collapse of the USSR and the reunification of Germany placed constraints on the budgets for further reactors. Eskom recognized that it could gain access to billions of Rands worth of fully-developed technology that might otherwise lie idle. In 1999, Eskom obtained the right to access the HTR engineering database that includes details of the Siemens/Interatom HTR-Module design. This design can be regarded as the forerunner of the South African PBMR concept. The PBMR core design was made using the same design philosophy as was used in the design of the HTR-Module. A concept license was issued for this reactor, and the safety arguments used in the HTR-Module safety application are relevant to the PBMR safety case.

Many components used in the fuel handling and control systems of the PBMR are copies of those used in the THTR program. They include all the improvements made over the years, thus saving a lot of costly development work. The PBMR concept also includes the technological advances made in gas turbine technology since the 1980s. The small plant size and the elimination of a steam cycle both contribute to the achievement of a plant configuration with a very robust safety case. The fuel design of the PBMR falls within the qualified fuel design parameters of the German fuel program. The actual fuel design is that specified for the Siemens/Interatom Modul reactor, which was qualified and received provisional certification in Germany.

Increased energy demand, escalating and increasingly volatile natural gas and oil costs, and a desire for energy security and environmental sustainability are stimulating investments in technologies that will contribute to reliable, affordable and clean energy on a global scale. Fossil resources supply approximately $80 \%$ of global energy, but their continued use is constrained by the increasing cost of available reserves and their adverse effects on our environmental wellbeing. Nuclear energy provides a solution for safe, reliable, affordable and clean air energy. 
Electricity generation from fossil fuels accounts for only one third of global $\mathrm{CO}_{2}$ emissions, with over half of all emissions resulting from the industrial and transport sectors. An opportunity exists to introduce nuclear energy into the industrial and transport sector, by supplying process heat to produce cleaner gases, chemical products and liquid petroleum fuels. The nuclear heat source must, however, be demonstrably safe, economic, match process energy needs and produce the required temperatures.

South Africa's PBMR technology fits each of these requirements. Because of its very high outlet temperatures of $950^{\circ} \mathrm{C}$, the heat from the PBMR can be applied for a variety of industrial process applications. Notably, the PBMR's energy can be used for the production of non-carbon derived hydrogen for transportation fuel or for upgrading coal and heavy crude oils into usable products, thereby relieving pressure on natural gas supply (the source of most hydrogen produced today). It can also produce heat to extract oil from tar sands, and for many other industrial applications where fossil fuels are currently used as the primary sources of energy.

\section{Main power system layout}

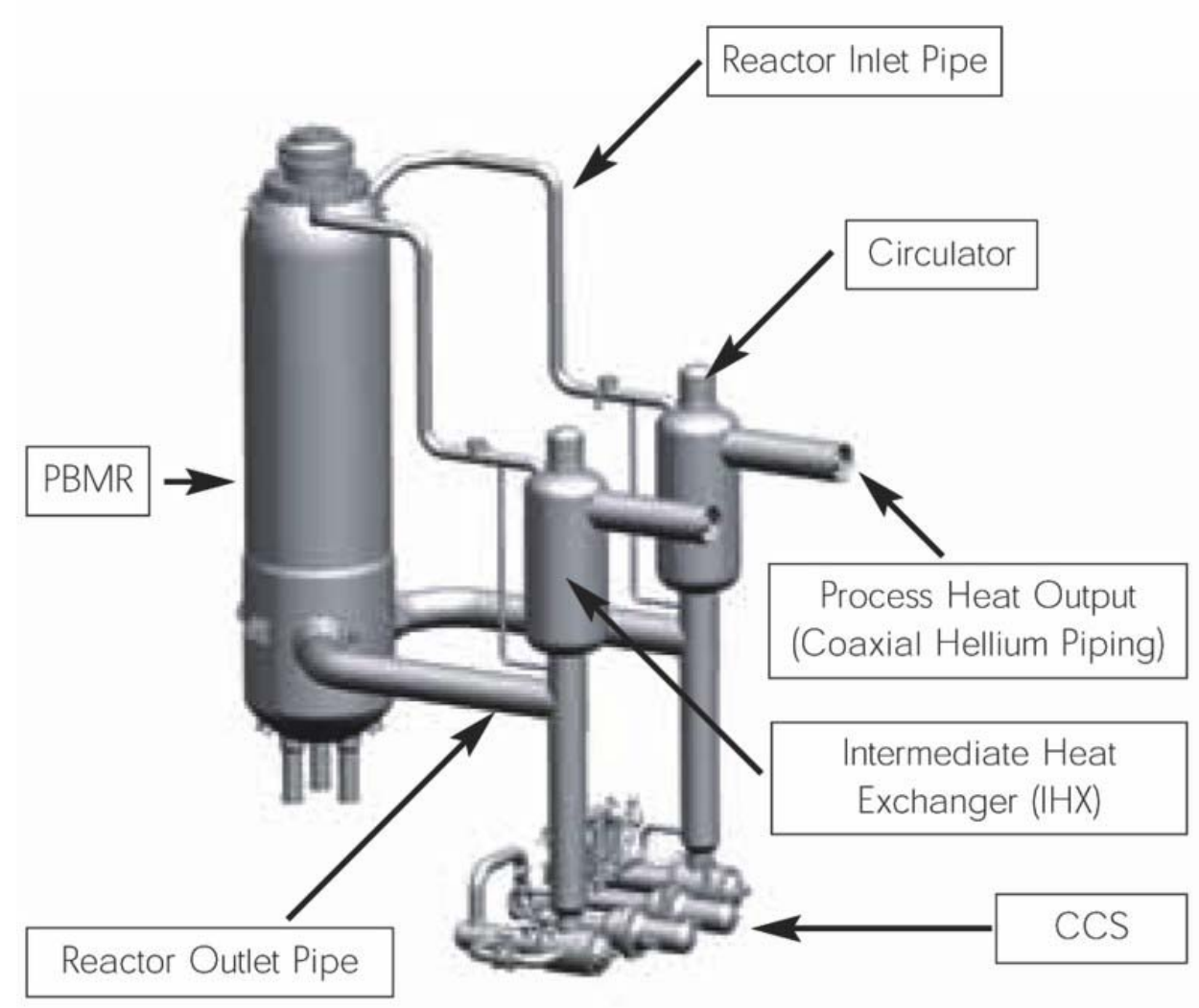

Figure 9-6 Main power system layout 
The schematic in Figure 9-6 shows a typical PBMR Process Heat configuration. The hot helium exits the bottom of the reactor and passes through helium-to-helium heat exchangers. Circulators located on top of the heat exchangers drive the gas back into the top of the pressure vessel and down through the annular gap between the pressure vessel and the core barrel (where after it is directed upwards via the riser channels). Helium in an intermediate loop (concentric pipes) transfers the heat to a series of process coupling heat exchangers (not shown).

The intermediate loop's helium enters and leaves the two secondary heat exchangers via the concentric pipes shown. For process applications in the $700^{\circ} \mathrm{C}$ temperature range, the intermediate heat exchangers will be virtually identical to the recuperator of the demonstration power plant. The actual process heat plant configuration will depend on the specific process heat application and its associated energy requirements.

\subsubsection{Why PBMR for Process Heat}

PBMR technology has unique features which make it well-suited as heat source for process applications:

- Access to niche high-temperature process markets due to its ability to provide process temperatures up to $900^{\circ} \mathrm{C}$ (reactor outlet of $950^{\circ} \mathrm{C}$ ).

- Well-matched to industrial process sizes (400-500 $\left.\mathrm{MW}_{\text {th }}\right)$.

- Ability to co-locate with industrial process plants due to inherent safety characteristics and small exclusion zone.

- Near-term availability.

- Economic benefits include displacement of premium fossil fuels, value from avoided $\mathrm{CO}_{2}$ emissions, high availability due to distributed generation, short construction times and reduced financing costs during construction.

- Well-suited for first world and developing markets due to its proliferation resistance and investment protection features. Addresses distributed need for electricity and desalination.

- High plant availability due to continuous online refueling.

\subsubsection{Product Range}

The first phase of the South African PBMR project entails the building of a $165-\mathrm{MW}_{\mathrm{e}}(400-$ $\mathrm{MW}_{\text {th }}$ ) power plant at Koeberg near Cape Town and a fuel plant at Pelindaba near Pretoria. The power plant will form the basis for the multi-module electricity plants and also the follow-on Process Heat Plants (PHPs). These future plants will be based on the power plant's physical reactor design within the same core dimensions.

The follow-on PBMR process heat plant is envisaged to operate at power levels between 400-500 $\mathrm{MW}_{\text {th }}$ with reactor outlet temperatures up to $950^{\circ} \mathrm{C}$. The configuration of the PBMR process heat plants will depend on the specific process heat application. Though the reactor core dimensions will remain the same for different process heat applications, the technology can be differentiated into two configurations, depending on the reactor outlet temperature: 
- An Intermediate Temperature Gas-cooled Reactor (ITGR), operating at reactor outlet temperatures up to $750^{\circ} \mathrm{C}$.

- An HTGR, operating at reactor outlet temperatures up to $950^{\circ} \mathrm{C}$. This is essentially a so-called Very High Temperature Reactor (VHTR) which is generally expected to operate at temperatures in the $900^{\circ} \mathrm{C}$ temperature range.

\subsubsection{Process Applications and Markets}

Heat from the PBMR can be used for a variety of industrial process applications. Intermediate (up to $750^{\circ} \mathrm{C}$ ) temperatures can be used to generate process steam for cogeneration applications, electricity production, in-situ oil sands recovery, ethanol applications, refinery and petrochemical applications. Higher temperatures $\left(900^{\circ} \mathrm{C}\right.$ range) can be used to efficiently co-produce electricity to reform methane to produce syngas (where the syngas can be used as feedstock to produce hydrogen, ammonia and methanol); and to produce hydrogen and oxygen by decomposing water thermochemically.

Hydrogen can be sold as a merchant product, or directly supplied to various industrial operations such as coal-to-liquids, coal-to-gas, refineries, petrochemical applications and steel production operations. Lower temperature waste heat can be used to produce water via desalination processes.

The size of the market is illustrated by the fact that the global installed capacity of desalination plants is more than 35 million cubic meters per day and growing by $7 \%$ per year. There are more than 12,500 desalination plants worldwide, most of which use fossil fuel energy sources.

In South Africa, there is interest in the possible use of PBMR technology in petrochemical complexes, notably for the synthetic fuels giant Sasol, to either produce process steam and/or hydrogen to upgrade coal products.

In Canada, there is interest from oil sands producers to use the PBMR to produce the temperature and associated pressure needed to extract bitumen from oil sands instead of gasfired plants currently in use. In the US, PBMR is a partner in the Westinghouse-led consortium which has been awarded a contract by the US Department of Energy to consider PBMR technology as the heat source for producing non-carbon hydrogen. The NGNP project, which aims to use HTGR technology to produce hydrogen and electricity, is still in its pre-conceptual phase, but it could result in the construction of a South African-designed PBMR in the US before the end of the next decade.

\subsubsection{Value proposition}

Attractive applications for nuclear process heat are driven primarily by the opportunity to displace natural gas and other premium fuels, and to respond to incentives to reduce $\mathrm{CO}_{2}$ emissions. Even with conservatively low forecasts for growth in long-term gas prices, clear commercial benefit exists in reducing exposure to their volatility and rapid increase. Economic assessments of PBMR process heat applications, based on current trends, have 
confirmed that PBMR is likely to become economically competitive in many markets, especially markets with high premium fuel costs and $\mathrm{CO}_{2}$ emission. 


\subsection{APPENDIX - ENERGY INTEGRATION STUDY}

Appendix 10.0 contains the enthalpy/temperature diagrams developed for the energy integration analysis and the process heat exchanger summary and energy balance table that are described in Section 5.7 


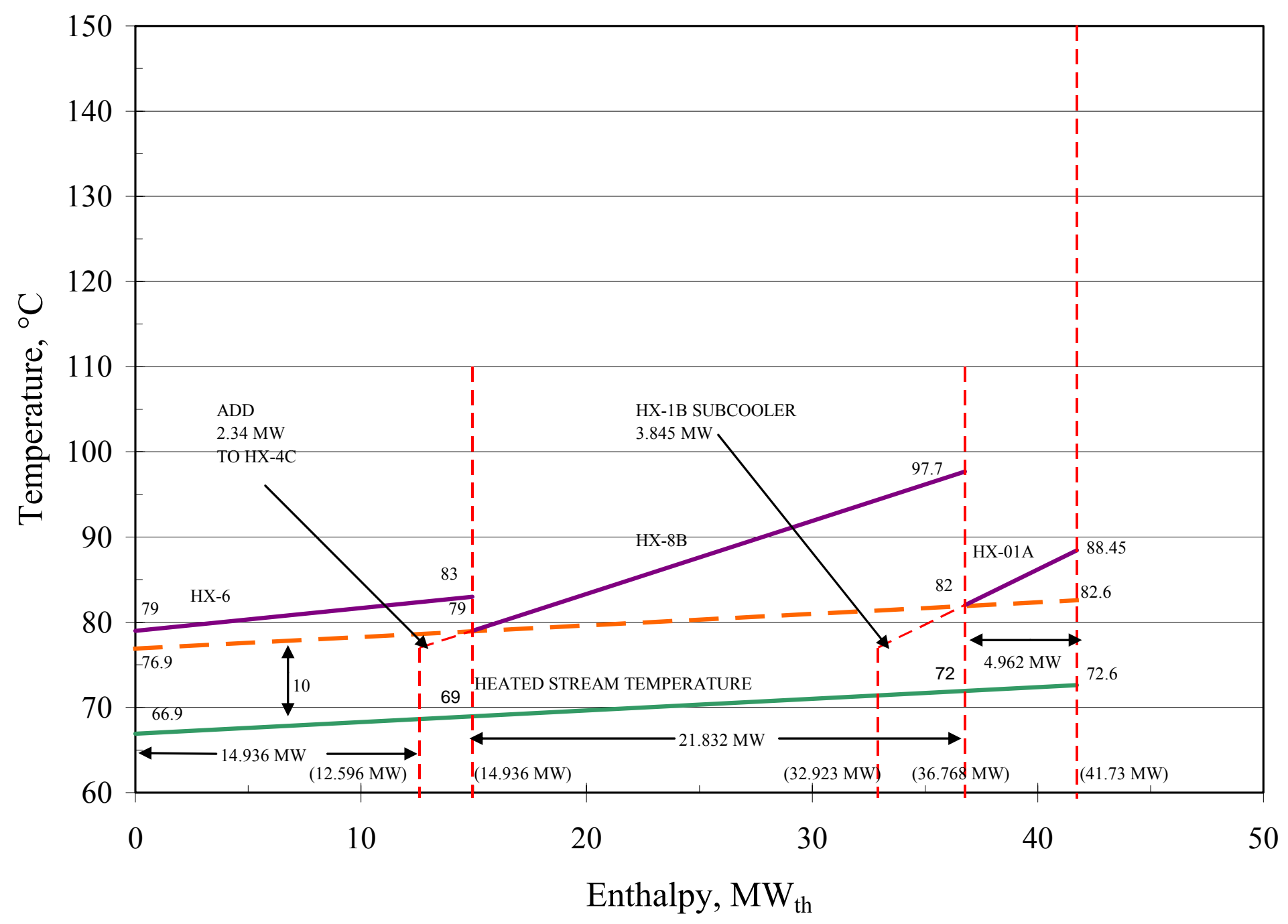

Figure 10-1 HX-2.1 Heat Integration Analysis 


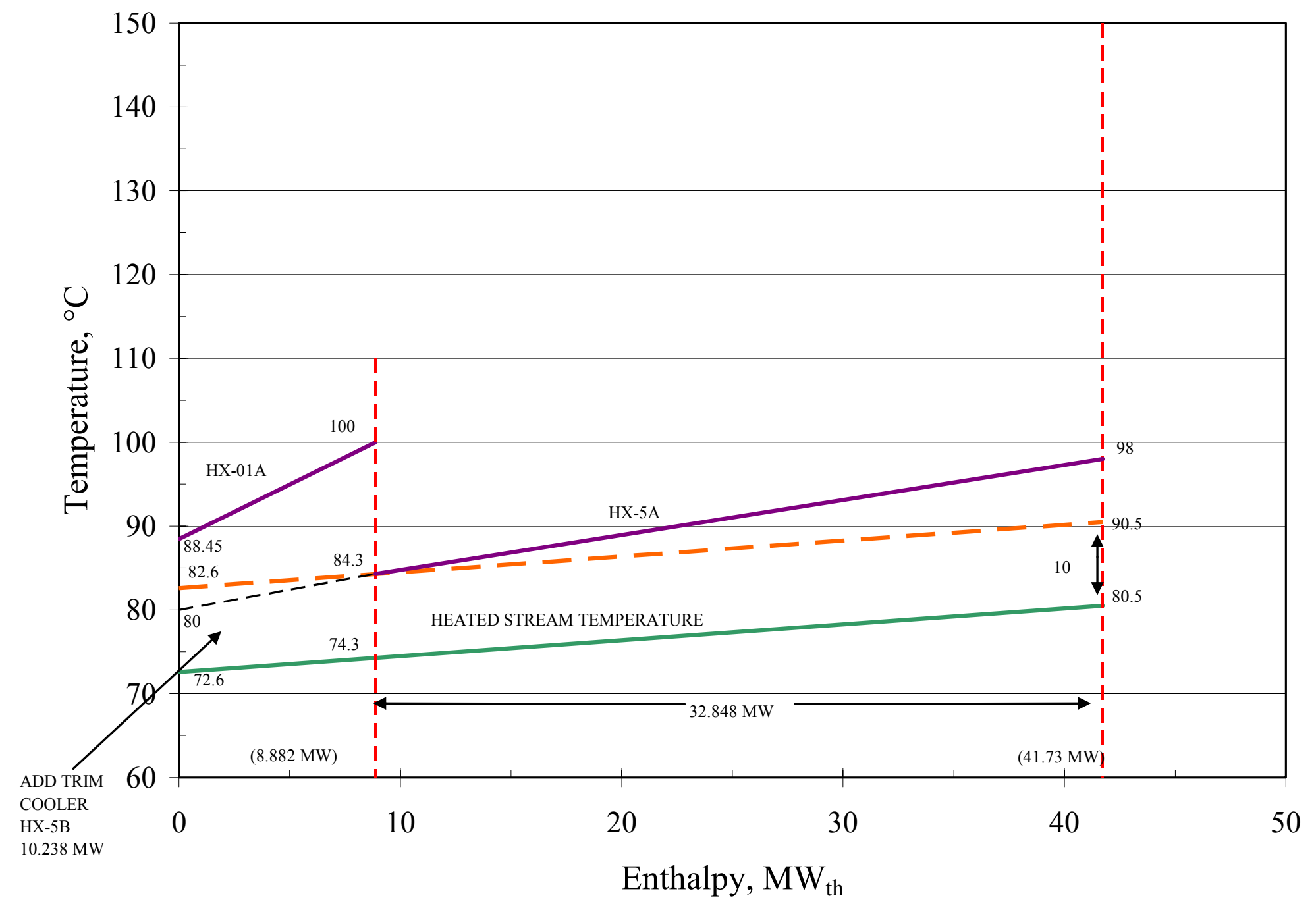

Figure 10-2 HX-2.2 Heat Integration Analysis

Page 126 


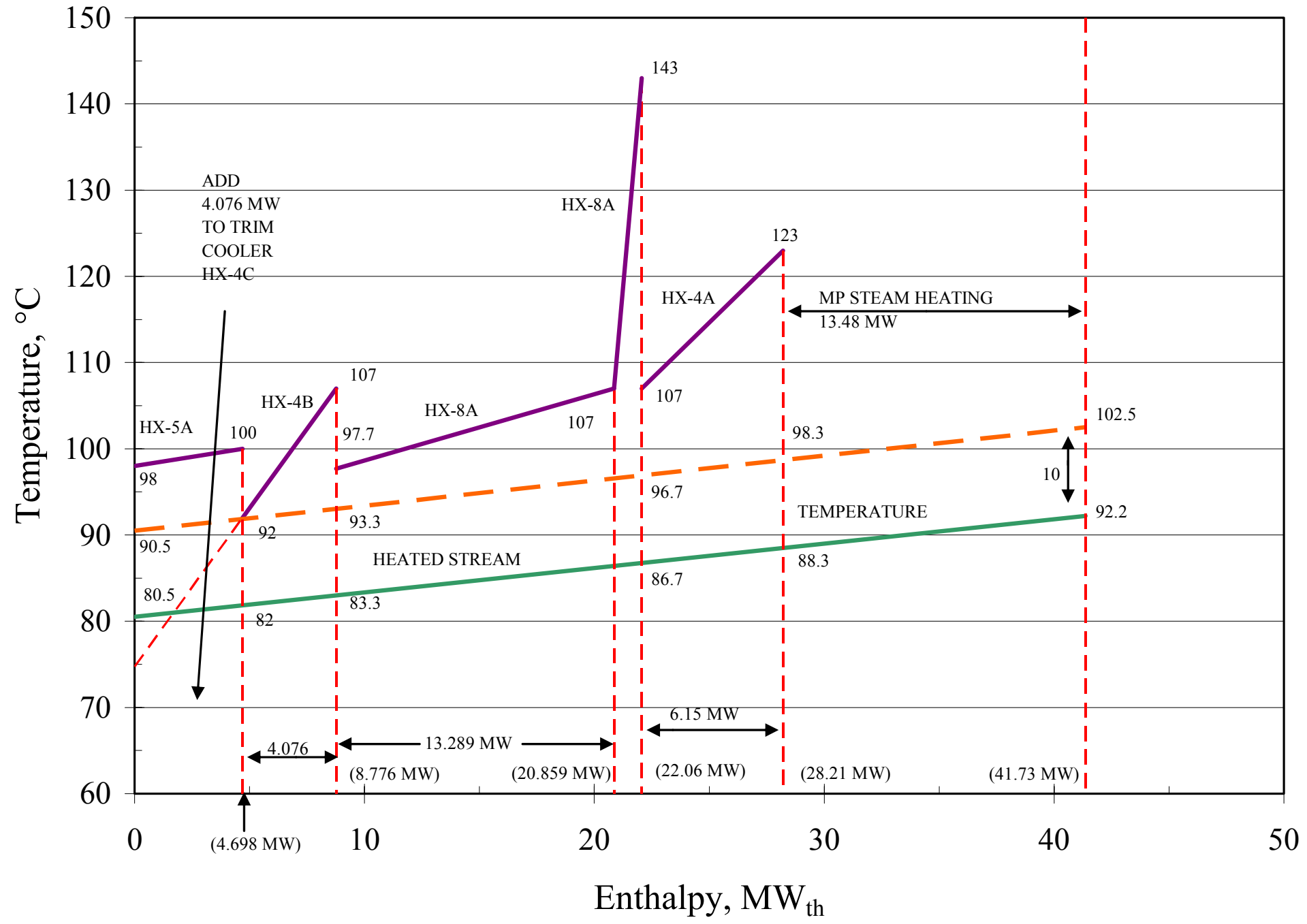

Figure 10-3 HX-2.3 Heat Integration Analysis 
Table 10-1 HyS Process Heat Exchanger Summary and Energy Balance

\begin{tabular}{|c|c|c|c|c|c|c|c|c|c|c|c|c|c|c|c|c|}
\hline \multirow[b]{2}{*}{ Equipment No. } & \multirow[b]{2}{*}{$\begin{array}{c}\text { Stream } \\
\text { No. }\end{array}$} & \multirow[b]{2}{*}{$\begin{array}{c}\text { Matl. of } \\
\text { Construction }\end{array}$} & \multirow[b]{2}{*}{ Equipment Name } & \multicolumn{2}{|c|}{ Temperature, ${ }^{\circ} \mathrm{C}$} & \multicolumn{2}{|c|}{ Temp. Diff., ${ }^{\circ} \mathrm{C}$} & \multirow[b]{2}{*}{$\left|\begin{array}{l}\text { Log-mean } \\
\text { delta } T,{ }^{\circ} \mathrm{C}\end{array}\right|$} & \multicolumn{2}{|c|}{ Enthalpy change, $\mathrm{MW}_{\text {th }}$} & \multirow[b]{2}{*}{$\begin{array}{c}\text { Pressure, } \\
\text { bar }\end{array}$} & \multirow[b]{2}{*}{ State } & \multicolumn{2}{|c|}{ Overall Ht. Transf. Coeff. } & \multirow[b]{2}{*}{$\begin{array}{c}\text { Exchanger } \\
\text { Area, } \mathrm{m}^{2}\end{array}$} & \multirow[b]{2}{*}{ Notes } \\
\hline & & & & Inlet & Outlet & Lesser & Greater & & Nominal & Sizing & & & $\begin{array}{c}\text { BTU } / \mathrm{hr}-\mathrm{ft}^{2}- \\
{ }^{\circ} \mathrm{F}\end{array}$ & $\mathrm{W} / \mathrm{m}^{2}-{ }^{\circ} \mathrm{C}$ & & \\
\hline \multirow[t]{2}{*}{ CO-01 HX1 } & 62 & $316 \mathrm{SS}$ & CO-01 $1^{\text {st }}$ Stage & 138.0 & 40.0 & 10.0 & 103.0 & 39.9 & 2.282 & 2.159 & 2.7 & V & 40 & 227 & 238 & Water-Cooled \\
\hline & & & Condenser & 30.0 & 35.0 & & & & & & & $\mathrm{H}_{2} \mathrm{O}$ & & & & \\
\hline \multirow[t]{2}{*}{ CO-01 HX2 } & 64 & $316 \mathrm{SS}$ & CO-01 $2^{\text {nd }}$ Stage & 138.0 & 40.0 & 10.0 & 103.0 & 39.9 & 9.097 & 8.608 & 7.6 & $\mathrm{~V}$ & 40 & 227 & 950 & Water-Cooled \\
\hline & & & Condenser & 30.0 & 35.0 & & & & & & & $\mathrm{H}_{2} \mathrm{O}$ & & & & \\
\hline \multirow[t]{2}{*}{$\mathrm{CO}-01 \mathrm{HX} 3$} & 59 & $316 \mathrm{SS}$ & CO-01 $3^{\text {rd }}$ Stage & 144.0 & 40.0 & 10.0 & 109.0 & 41.4 & 0.137 & 0.130 & 21.0 & $\mathrm{~V}$ & 40 & 227 & 14 & Water-Cooled \\
\hline & & & Condenser & 30.0 & 35.0 & & & & & & & $\mathrm{H}_{2} \mathrm{O}$ & & & & \\
\hline \multirow[t]{2}{*}{ HX-01A } & 3 & $\mathrm{CS}$ & $1^{\text {st }}$ Hydrogen & 100.0 & 82.0 & 10.0 & 25.7 & 16.6 & 13.844 & 13.099 & 20.0 & $\mathrm{~V}$ & 75 & 426 & 1849 & Before HX- $023^{\text {rd }}$ heater \\
\hline & & & Vapor Cooler & 72.0 & 74.3 & & & & & & 0.1 & Acid $15 \% \mathrm{~V}$ & & & & \\
\hline \multirow[t]{2}{*}{ HX-01B } & 3 & $\mathrm{CS}$ & $2^{\text {nd }}$ Hydrogen & 82.0 & 76.9 & 46.9 & 47.0 & 46.9 & 3.845 & 3.638 & 20.0 & $\mathrm{~V}$ & 85 & 483 & 161 & Water-Cooled \\
\hline & & & Vapor Cooler & 30.0 & 35.0 & & & & & & & $\mathrm{H}_{2} \mathrm{O}$ & & & & \\
\hline \multirow[t]{2}{*}{ HX-02 (Steam) } & 17 & $20 \mathrm{BC} 3$ & Feed & 88.3 & 92.2 & 77.8 & 81.7 & 79.7 & 13.515 & 12.788 & 0.10 & Acid $30 \% \mathrm{~V}$ & 210 & 1192 & 134 & Trim Steam Heater \\
\hline & & & Preheater HX-02 & 170.0 & 170.0 & & & & & & 7.90 & Steam & & & & Steam@ @ 7.91 bar \\
\hline \multirow[t]{2}{*}{ HX-03 (Steam) } & 29 & B3 & Feed & 107.0 & 110.0 & 60.0 & 63.0 & 61.5 & 7.359 & 6.963 & 0.13 & Acid $12 \% \mathrm{~V}$ & 210 & 1192 & 95 & Trim Steam Heater \\
\hline & & & Preheater HX-03 & 170.0 & 170.0 & & & & & & 7.9 & Steam & & & & Steam@7.91 bar \\
\hline \multirow[t]{2}{*}{ HX-04A-1 } & $29 / 31$ & B3 & Reactor Ovhd & 245.0 & 123.0 & 26.0 & 138.0 & 67.1 & 24.609 & 23.285 & 76.0 & $\mathrm{~V}$ & 75 & 426 & 815 & Before HX-03 $1^{\text {st }}$ Heater \\
\hline & & & Condenser \#1 & 97.0 & 107.0 & & & & & & 0.1 & Acid $12 \% \mathrm{~V}$ & & & & \\
\hline \multirow[t]{2}{*}{ HX-04A-2 } & $17 / 31$ & $20 \mathrm{CB} 3$ & Reactor Ovhd & 123.0 & 107.0 & 20.3 & 34.7 & 26.9 & 6.153 & 5.822 & 76.0 & Condensing & 140 & 795 & 273 & Before HX-02 $7^{\text {th }}$ Heater \\
\hline & & & Condenser \#2 & 86.7 & 88.3 & & & & & & 0.1 & Acid $25 \% \mathrm{~V}$ & & & & \\
\hline \multirow{2}{*}{ HX-04B } & $17 / 32$ & $20 \mathrm{CB} 3$ & Reactor Ovhd & 107.0 & 92.0 & 10.0 & 23.7 & 15.9 & 4.078 & 3.859 & 76.0 & Condensing & 140 & 795 & 306 & Before HX-02 $5^{\text {th }}$ Heater \\
\hline & & & Condenser \#3 & 82.0 & 83.3 & & & & & & 0.1 & Acid $25 \% \mathrm{~V}$ & & & & \\
\hline \multirow{2}{*}{ HX-04C } & 33 & $316 \mathrm{SS}$ & Reactor Ovhd & 92.0 & 40.0 & 10.0 & 57.0 & 27.0 & 10.687 & 10.112 & 76.0 & Condensing & 210 & 1192 & 314 & Water-Cooled \\
\hline & & & Trim Cooler & 30.0 & 35.0 & & & & & & & $\mathrm{H}_{2} \mathrm{O}$ & & & & \\
\hline HX-05A & $17 / 48$ & $20 \mathrm{CB} 3$ & Anolyte Recirc & 100.0 & 84.3 & 10.0 & 18.0 & 13.6 & 37.546 & 35.526 & 20.0 & Acid L & 165 & 937 & 2786 & Before HX-02 $4^{\text {th }}$ Heater \\
\hline & & & Cooler & 74.3 & 82.0 & & & & & & 0.1 & Acid $15 \% \mathrm{~V}$ & & & & \\
\hline HX-05B & 48 & B3 & Anolyte Recirc & 84.3 & 80.0 & 50.0 & 49.3 & 49.6 & 10.284 & 9.731 & 20.0 & Acid L & 165 & 937 & 209 & Water-Cooled \\
\hline & & & Trim Cooler & 30.0 & 35.0 & & & & & & & $\mathrm{H}_{2} \mathrm{O}$ & & & & \\
\hline HX-06 & $17 / 51$ & $20 \mathrm{CB} 3$ & $\mathrm{H}_{2} \mathrm{SO}_{4}$ Feed & 83.0 & 79.0 & 12.1 & 14.0 & 13.0 & 14.936 & 14.132 & 21.0 & Acid L & 165 & 937 & 1158 & Before HX-02 $1^{\text {st }}$ Heater \\
\hline & & & Cooler & 66.9 & 69.0 & & & & & & 0.1 & Acid L & & & & \\
\hline HX-07 & 52 & $316 \mathrm{SS}$ & KO-02 Ovhd & 84.0 & 40.0 & 10.0 & 49.0 & 24.5 & 3.728 & 3.527 & 1.0 & $\mathrm{~V}$ & 30 & 170 & 844 & Water-Cooled \\
\hline & & & Vapor Cooler & 30.0 & 35.0 & & & & & & & $\mathrm{H}_{2} \mathrm{O}$ & & & & \\
\hline HX-08A & $17 / 54$ & $20 \mathrm{CB} 3$ & KO-06 & 143.0 & 97.7 & 14.4 & 56.3 & 30.7 & 13.289 & 12.574 & 1.0 & $\mathrm{~V}$ & 30 & 170 & 2402 & Before HX-02 $6^{\text {th }}$ Heater \\
\hline & & & Vapor Cooler & 83.3 & 86.7 & & & & & & 0.1 & Acid $25 \% \mathrm{~V}$ & & & & \\
\hline
\end{tabular}


Table 10-1 HyS Process Heat Exchanger Summary and Energy Balance, cont'd

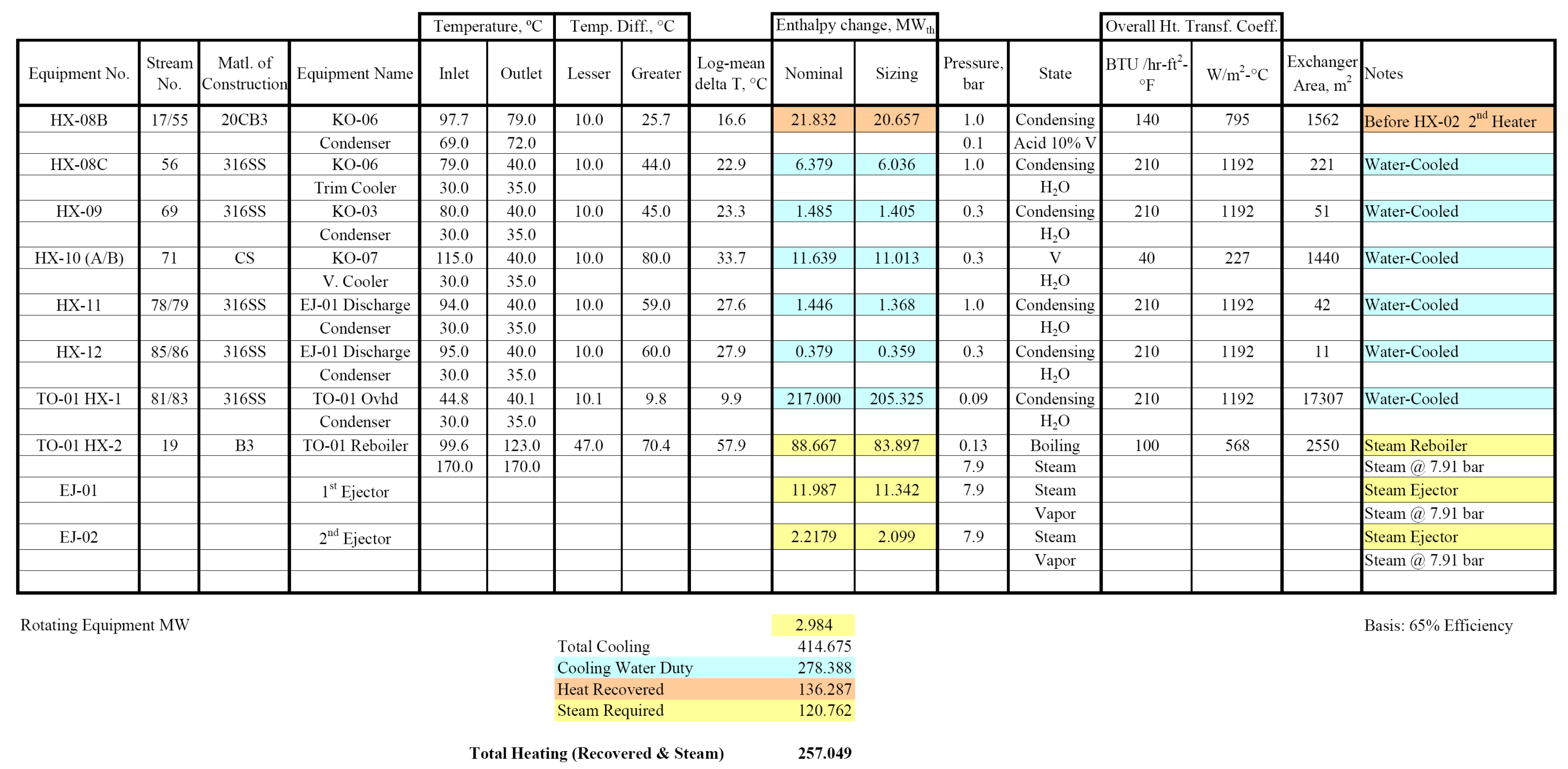




\subsection{APPENDIX - HYBRID SULFUR PLANT EQUIPMENT LIST}

Appendix 11.0 contains the HyS plant major equipment list mentioned in Section 6.2.1.

\subsection{ELECTROLYSIS SECTION}

Table 11-1 Electrolysis Section Vessels/Reactors

\begin{tabular}{|c|c|c|c|c|c|c|c|c|c|}
\hline \multicolumn{10}{|c|}{ EQUIPMENT LIST - VESSELS / REACTORS } \\
\hline \multicolumn{5}{|c|}{ Client: Westinghouse Electric Company } & \multicolumn{5}{|c|}{ Signature: TGS } \\
\hline \multicolumn{5}{|c|}{ Unit: Hybrid Sulfur TCA } & \multicolumn{5}{|c|}{ Location: Pittsburgh, PA } \\
\hline \multirow[b]{2}{*}{ Item No. } & \multirow[b]{2}{*}{ Name } & \multirow[b]{2}{*}{$\begin{array}{c}\text { Dlameter } \\
(\mathrm{mm})\end{array}$} & \multirow[b]{2}{*}{$\begin{array}{l}\text { Length } \\
(\mathrm{mm})\end{array}$} & \multirow[b]{2}{*}{$\begin{array}{l}\text { Horizon/ } \\
\text { Vertical }\end{array}$} & \multicolumn{2}{|c|}{ Mechanical Design } & \multirow{2}{*}{$\begin{array}{l}\text { Material } \\
\text { C.A. (mm) }\end{array}$} & \multirow[b]{2}{*}{ PFD } & \multirow[b]{2}{*}{ Remarks } \\
\hline & & & & & $\begin{array}{c}\text { Pressure } \\
\text { (barg) }\end{array}$ & $\begin{array}{c}\text { Temperature } \\
\left({ }^{\circ} \mathrm{C}\right)\end{array}$ & & & \\
\hline $\begin{array}{c}\text { HPS.ELE } \\
\text { KO-1 } \\
A / B / C / D\end{array}$ & $\begin{array}{l}\text { Catholyte Surge } \\
\text { Drum }\end{array}$ & 2900 & 8700 & Horizontal & 23 & 130 & $\begin{array}{l}\text { TFE lined } \\
\text { CS }\end{array}$ & ELE-301 & \\
\hline
\end{tabular}

\section{Table 11-2 Electrolysis Section Pumps}

\begin{tabular}{|c|c|c|c|c|c|c|c|c|c|}
\hline \multicolumn{10}{|c|}{ EQUIPMENT LIST - PUMPS } \\
\hline \multicolumn{5}{|c|}{ Client: Westinghouse Electric Company } & \multicolumn{5}{|c|}{ Signature: TGS } \\
\hline \multicolumn{5}{|c|}{ Unit: Hybrid Sulfur TCA } & \multicolumn{5}{|c|}{ Location: Pittsburgh, PA } \\
\hline \multirow{2}{*}{ Item No. } & \multirow{2}{*}{ Name } & \multirow{2}{*}{ Type } & \multirow{2}{*}{$\begin{array}{l}\text { Rated } \\
\text { Flow } \\
\left(\mathrm{m}^{3} / \mathrm{h}\right)\end{array}$} & \multirow{2}{*}{$\begin{array}{c}\text { Differential } \\
\text { Pressure } \\
\text { bar }\end{array}$} & \multirow{2}{*}{$\begin{array}{l}\text { Motor } \\
\mathrm{kW}(\mathrm{HP})\end{array}$} & \multicolumn{2}{|c|}{ Material } & \multirow{2}{*}{ PFD } & \multirow{2}{*}{ Remarks } \\
\hline & & & & & & Casing & Impeller & & \\
\hline $\begin{array}{l}\text { HPS-ELE } \\
\text { PP-01 } \\
\text { ABB/C/D/E }\end{array}$ & $\begin{array}{l}\text { Electrolyzer Catholyte } \\
\text { Recirculation Pumps }\end{array}$ & Centrif. & 195 & 2 & 18.5 & Alloy B3 & Alloy B3 & ELE-301 & $80.5 \%$ Efficiency \\
\hline
\end{tabular}


Table 11-3 Electrolysis Section Heat Exchangers

\begin{tabular}{|c|c|c|c|c|c|c|c|}
\hline \multicolumn{8}{|c|}{ EQUIPMENT LIST - HEAT EXCHANGERS } \\
\hline \multicolumn{3}{|c|}{ Client: Westinghouse Electric Company } & & & \multicolumn{3}{|c|}{ Signature: TGS } \\
\hline \multicolumn{4}{|c|}{ Unit: Hybrid Sulfur TCA } & & \multicolumn{3}{|c|}{ Location: Pittsburgh, PA } \\
\hline \multirow{3}{*}{ Item No. } & \multirow{3}{*}{ Name } & \multirow{3}{*}{$\begin{array}{l}\text { Area } \\
\left(\mathrm{m}^{2}\right)\end{array}$} & \multicolumn{2}{|c|}{ Mechanical Design } & \multirow{3}{*}{ Type } & \multirow{3}{*}{ PFD } & \multirow{3}{*}{ Remarks } \\
\hline & & & Shell & \multirow{2}{*}{$\begin{array}{c}\text { Tube } \\
\text { Material } \\
\text { Pressure (bar g) } \\
\text { Temperature } \\
\left({ }^{\circ} \mathrm{C}\right)\end{array}$} & & & \\
\hline & & & $\begin{array}{c}\text { Material } \\
\text { Pressure (bar g) } \\
\text { Temperature } \\
\left({ }^{\circ} \mathrm{C}\right)\end{array}$ & & & & \\
\hline $\begin{array}{l}\text { HPS-ELE } \\
\text { HX-01A } \\
\text { A/B/C/D }\end{array}$ & $\begin{array}{l}1^{\text {st }} \text { Hydrogen } \\
\text { Vapor Cooler }\end{array}$ & 1880 & $\begin{array}{c}20 \mathrm{Cb} 3 \\
23 \\
130\end{array}$ & $\begin{array}{c}20 \mathrm{Cb} 3 \\
17 \\
100\end{array}$ & BEU & ELE-301 & Area shown is for 4 trains \\
\hline $\begin{array}{l}\text { HPS-ELE } \\
\text { HX-01B } \\
\text { A/B/C/D }\end{array}$ & $\begin{array}{l}2^{\text {nd }} \text { Hydrogen } \\
\text { Vapor Cooler }\end{array}$ & 160 & $\begin{array}{c}20 \mathrm{Cb} 3 \\
23 \\
130 \\
\end{array}$ & $\begin{array}{c}\mathrm{CS} / 20 \mathrm{Cb} 3 \\
17 \\
100 \\
\end{array}$ & BEU & ELE-301 & Area shown is for 4 trains \\
\hline $\begin{array}{l}\text { HPS-ELE } \\
\text { HX-05A }\end{array}$ & Anolyte Cooler & 2800 & $\begin{array}{c}\text { Alloy B3 } \\
23 \\
130\end{array}$ & $\begin{array}{c}20 \mathrm{Cb} 3 \\
17 \\
100\end{array}$ & BEU & ELE-301 & \\
\hline $\begin{array}{c}\text { HPS-ELE } \\
\text { HX-05B }\end{array}$ & $\begin{array}{l}\text { Anolyte Trim } \\
\text { Cooler }\end{array}$ & 210 & $\begin{array}{c}\text { Alloy B3 } \\
23 \\
130\end{array}$ & $\begin{array}{c}\text { Alloy B3 } \\
17 \\
130\end{array}$ & BEU & ELE-301 & \\
\hline $\begin{array}{c}\text { HPS-ELE } \\
\text { HX-06 }\end{array}$ & $\begin{array}{l}\text { Anolyte/ Vacuum } \\
\text { Column Feed } \\
\text { Interchanger }\end{array}$ & 1200 & $\begin{array}{c}20 \mathrm{Cb} 3 \\
23 \\
115 \\
\end{array}$ & $\begin{array}{c}20 \mathrm{Cb} 3 \\
17 \\
100 \\
\end{array}$ & BEU & ELE-301 & \\
\hline
\end{tabular}

\section{Table 11-4 Electrolysis Section Miscellaneous Equipment}

\begin{tabular}{|c|c|c|c|c|}
\hline \multicolumn{5}{|c|}{ EQUIPMENT LIST - MISCELLANEOUS } \\
\hline \multicolumn{3}{|c|}{ Client: Westinghouse Electric Company } & \multicolumn{2}{|l|}{ Signature: TGS } \\
\hline \multicolumn{3}{|c|}{ Unit: Hybrid Sulfur TCA } & \multicolumn{2}{|c|}{ Location: Pittsburgh, PA } \\
\hline Item No. & Name & Material & PFD & Duty - Description - Remarks \\
\hline $\begin{array}{c}\text { HPS-ELE } \\
\text { EL-01 } \\
\text { AAA- } \\
\text { ABV/BAA- } \\
\text { BBV/CAA- } \\
\text { CBV/DAA- } \\
\text { DBV }\end{array}$ & Electrolyzer & Graphite & ELE-301 & $\begin{array}{l}\text { 4 banks of } 48 \text { modules each; } 192 \text { modules } \\
\text { Design pressure: } 300 \text { psig. Cylindrical module made up of } 200 \\
\text { circular bipolar plate cells with an OD of } 1.22 \text { meters ( } 48 \text { inches). } \\
\text { The total thickness of each cell is } 0.5 \text { inches; the overall length of } \\
\text { the } 200 \text { cell stack is } 2.54 \text { meters ( } 100 \text { inches). The overall length of } \\
\text { a module, including the end plates and other structural components, } \\
\text { is } 3.15 \text { meters ( } 124 \text { inches). Weight per module is about } 8 \text { tons } \\
\text { Cost of module F.O.B. at manufacturer's plant: } \$ 391,600 ; \\
\text { Electricals: } \$ 54.5 \text { Million (Materials only; installation not included) } \\
\text { A building is needed to house the electrolyzers, electricals and } \\
\text { control room: Total floor area: about } 40,000 \text { sq. } \mathrm{ft} \text {. }\end{array}$ \\
\hline $\begin{array}{l}\text { HPS-ELE } \\
\text { FF-01 A-H }\end{array}$ & $\begin{array}{c}\text { Electrolyzer } \\
\text { Catholyte Filters }\end{array}$ & TFE lined CS & ELE-301 & $\begin{array}{l}\text { PALL Fluoryte }{ }^{\mathrm{TM}} \text { High Flow Filter (Cartridge filter) } \\
\text { PTFE cartridge elements; Des. P: } 23 \text { bar g: Des. T: } 100^{\circ} \mathrm{C} \\
\text { Diameter= } 1.25 \mathrm{~m} \text {; Length }=1.2 \mathrm{~m}, ; 24 \text { cartridges per case }, 8 \text { cases }\end{array}$ \\
\hline $\begin{array}{l}\text { HPS-ELE } \\
\text { FF-02 A-AJ }\end{array}$ & $\begin{array}{l}\text { Electrolyzer } \\
\text { Anolyte Filters }\end{array}$ & TFE lined CS & ELE-301 & $\begin{array}{c}\text { PALL Fluoryte }{ }^{\mathrm{TM}} \text { High Flow Filter (Cartridge filter) } \\
\text { PTFE cartridge elements; Des. P: } 23 \text { bar g; Des. T: } 100^{\circ} \mathrm{C} \\
\text { Diameter }=1.25 \mathrm{~m} \text {; Length }=1.2 \mathrm{~m} .: 24 \text { cartridges per case PTFE } \\
\text { elements, } 36 \text { cases }\end{array}$ \\
\hline
\end{tabular}




\subsection{SULFURIC ACID DECOMPOSITION SECTION}

Table 11-5 Sulfuric Acid Decomposition Section Towers

\begin{tabular}{|c|c|c|c|c|c|c|c|c|c|c|}
\hline \multicolumn{11}{|c|}{ EQUIPMENT LIST - TOWERS } \\
\hline \multicolumn{5}{|c|}{ Client: Westinghouse Electric Company } & \multicolumn{6}{|c|}{ Signature: TGS } \\
\hline \multicolumn{5}{|c|}{ Unit: Hybrid Sulfur TCA } & \multicolumn{6}{|c|}{ Location: Pittsburgh, PA } \\
\hline \multirow[b]{2}{*}{ Item No. } & \multirow[b]{2}{*}{ Name } & \multirow{2}{*}{$\begin{array}{l}\text { Diameter } \\
(\mathrm{mm})\end{array}$} & \multirow{2}{*}{$\begin{array}{l}\text { Height } \\
(\mathrm{mm})\end{array}$} & \multirow[b]{2}{*}{$\begin{array}{l}\text { Packing/ } \\
\text { Trays }\end{array}$} & \multicolumn{2}{|c|}{ Mechanical Design } & \multicolumn{2}{|c|}{ Material } & \multirow[b]{2}{*}{ PFD } & \multirow[b]{2}{*}{ Remarks } \\
\hline & & & & & $\begin{array}{l}\text { Press } \\
\text { (bar g) }\end{array}$ & Temp $\left({ }^{\circ} \mathrm{C}\right)$ & $\begin{array}{c}\text { Shell } \\
\text { C.A. }(\mathrm{mm})\end{array}$ & $\begin{array}{l}\text { Packing } \\
\text { Trays }\end{array}$ & & \\
\hline $\begin{array}{c}\text { HPS-SAD } \\
\text { TO-01 } \\
\text { A/B/C/D }\end{array}$ & $\begin{array}{l}\text { Vacuum } \\
\text { Column }\end{array}$ & $\begin{array}{l}6800 / 4600 \\
\text { (Bot/Top) }\end{array}$ & 14000 & Packing & $\begin{array}{l}3.5 \\
/ F V\end{array}$ & 145 & $\begin{array}{l}\text { Alloy B3 } \\
\text { Clad CS }\end{array}$ & Ceramic & $\begin{array}{l}\text { SAD- } \\
202\end{array}$ & $\begin{array}{l}\text { Koch Flexiramic } 88 \text { or } \\
\text { equal packing }\end{array}$ \\
\hline $\begin{array}{l}\text { HPS-SAD } \\
\text { TO-02 }\end{array}$ & $\begin{array}{l}\text { Absorber } \\
\text { Column }\end{array}$ & $\begin{array}{c}3000 / 2600 \\
\text { (Bot/Top) }\end{array}$ & 12800 & Packing & 22 & 115 & $316 \mathrm{~L}$ SS & Ceramic & $\begin{array}{l}\text { SAD- } \\
204\end{array}$ & $\begin{array}{c}\text { Koch Flexiramic } 88 \text { or } \\
\text { equal packing }\end{array}$ \\
\hline
\end{tabular}

Table 11-6 Sulfuric Acid Decomposition Section Vessels/Reactors

\begin{tabular}{|c|c|c|c|c|c|c|c|c|c|}
\hline \multicolumn{10}{|c|}{ EQUIPMENT LIST - VESSELS / REACTORS } \\
\hline \multicolumn{5}{|c|}{ Client: Westinghouse Electric Company } & \multicolumn{5}{|c|}{ Signature: TGS } \\
\hline \multicolumn{5}{|c|}{ Unit: Hybrid Sulfur TCA } & \multicolumn{5}{|c|}{ Location: Pittsburgh, PA } \\
\hline \multirow[b]{2}{*}{ Item No. } & \multirow[b]{2}{*}{ Name } & \multirow{2}{*}{$\begin{array}{l}\text { Diameter } \\
(\mathrm{mm})\end{array}$} & \multirow{2}{*}{$\begin{array}{l}\text { Length } \\
(\mathrm{mm})\end{array}$} & \multirow{2}{*}{$\begin{array}{l}\text { Horizon/ } \\
\text { Vertical }\end{array}$} & \multicolumn{2}{|c|}{ Mechanical Design } & \multirow{2}{*}{$\begin{array}{l}\text { Material } \\
\text { C.A. }(\mathrm{mm})\end{array}$} & \multirow[b]{2}{*}{ PFD } & \multirow[b]{2}{*}{ Remarks } \\
\hline & & & & & $\begin{array}{c}\text { Pressure } \\
\text { (barg) }\end{array}$ & Temp $\left({ }^{\circ} \mathrm{C}\right)$ & & & \\
\hline $\begin{array}{l}\text { HPS-SAD } \\
\text { RX-01 A/B }\end{array}$ & $\begin{array}{l}\text { Sulfuric Acid } \\
\text { Decomposer }\end{array}$ & 4800 & 10300 & Vertical & 90 & 300 & $\begin{array}{l}\text { He (Shell) } \\
\text { side: } \\
\text { Internally } \\
\text { insulated } \\
\text { CS, Process } \\
\text { side (Tube } \\
\text { side) TFE } \\
\text { lined CS, } \\
\text { Silicon } \\
\text { Carbide } \\
\text { tubes }\end{array}$ & SAD-203 & $\begin{array}{c}\text { Similar to a large, vertical, tubular } \\
\text { heat exchanger. Alloy B3 piping } \\
\text { on sulfuric acid side; Incoloy } 800 \mathrm{H} \\
\text { piping on the Helium side. } \\
\text { Hemispherical heads, cold wall } \\
\text { design } \\
2 \text { Units at } \$ 27 \text { million per unit, not } \\
\text { installed }\end{array}$ \\
\hline $\begin{array}{l}\text { HPS-SAD } \\
\text { KO-02 }\end{array}$ & $\begin{array}{c}50 \% \text { Acid } \\
\text { Flash Drum \#1 }\end{array}$ & 3900 & 11700 & Horizontal & 22.0 & 130 & $\begin{array}{c}20 \mathrm{Cb} 3 \\
\text { Clad CS }\end{array}$ & SAD-201 & \\
\hline $\begin{array}{l}\text { HPS-SAD } \\
\text { KO-03 }\end{array}$ & $\begin{array}{c}50 \% \text { Acid } \\
\text { Flash Drum \#2 }\end{array}$ & 3700 & 11100 & Horizontal & $\begin{array}{l}3.5 \\
/ F V\end{array}$ & 110 & $\begin{array}{c}20 \mathrm{Cb} 3 \\
\text { Clad CS }\end{array}$ & SAD-201 & \\
\hline $\begin{array}{l}\text { HPS-SAD } \\
\text { KO-04 }\end{array}$ & $\begin{array}{l}\text { Reactor Effluent } \\
\text { Flash Drum }\end{array}$ & 3800 & 11400 & Horizontal & 85 & 275 & $\begin{array}{l}\text { Alloy B3 } \\
\text { Clad CS }\end{array}$ & SAD-203 & \\
\hline $\begin{array}{l}\text { HPS-SAD } \\
\text { KO-05 }\end{array}$ & $\begin{array}{l}\text { Recycle Acid } \\
\text { Flash Drum }\end{array}$ & 3400 & 11200 & Horizontal & 24 & 260 & $\begin{array}{l}\text { Alloy B3 } \\
\text { Clad CS }\end{array}$ & SAD-203 & \\
\hline $\begin{array}{l}\text { HPS-SAD } \\
\text { KO-06 }\end{array}$ & $\begin{array}{l}1^{\text {st }} \text { Water Removal } \\
\text { Flash Drum }\end{array}$ & 3300 & 11200 & Horizontal & $\begin{array}{l}3.5 \\
/ \mathrm{FV}\end{array}$ & 175 & $\begin{array}{l}\text { Alloy B3 } \\
\text { Clad CS }\end{array}$ & SAD-201 & \\
\hline $\begin{array}{l}\text { HPS-SAD } \\
\text { KO-07 }\end{array}$ & $\begin{array}{l}2^{\text {nd }} \text { Water Removal } \\
\text { Flash Drum }\end{array}$ & 3300 & 10600 & Vertical & $\begin{array}{l}3.5 \\
/ \mathrm{FV}\end{array}$ & 145 & $\begin{array}{l}\text { Alloy B3 } \\
\text { Clad CS }\end{array}$ & SAD-201 & \\
\hline
\end{tabular}


Table 11-6 Sulfuric Acid Decomposition Section Vessels/Reactors, cont'd

\begin{tabular}{|c|c|c|c|c|c|c|c|c|c|}
\hline \multicolumn{10}{|c|}{ EQUIPMENT LIST - VESSELS / REACTORS } \\
\hline \multicolumn{5}{|c|}{ Client: Westinghouse Electric Company } & \multicolumn{5}{|c|}{ Signature: TGS } \\
\hline \multicolumn{5}{|c|}{ Unit: Hybrid Sulfur TCA } & \multicolumn{5}{|c|}{ Location: Pittsburgh, PA } \\
\hline \multirow{2}{*}{ Item No. } & \multirow{2}{*}{ Name } & \multirow{2}{*}{$\begin{array}{l}\text { Diameter } \\
(\mathrm{mm})\end{array}$} & \multirow{2}{*}{$\begin{array}{l}\text { Length } \\
(\mathrm{mm})\end{array}$} & \multirow{2}{*}{$\begin{array}{l}\text { Horizon/ } \\
\text { Vertical }\end{array}$} & \multicolumn{2}{|c|}{ Mechanical Design } & \multirow{2}{*}{$\begin{array}{l}\text { Material } \\
\text { C.A. }(\mathrm{mm})\end{array}$} & \multirow{2}{*}{ PFD } & \multirow{2}{*}{ Remarks } \\
\hline & & & & & $\begin{array}{c}\text { Pressure } \\
\text { (barg) }\end{array}$ & Temp $\left({ }^{\circ} \mathrm{C}\right)$ & & & \\
\hline $\begin{array}{l}\text { HPS-SAD } \\
\text { KO-08 }\end{array}$ & $\begin{array}{l}\text { Reactor Effluent } \\
\text { Acid Decanter }\end{array}$ & 2200 & 6600 & Horizontal & 84 & 100 & 316 LS & SAD-203 & \\
\hline $\begin{array}{l}\text { HPS-SAD } \\
\text { KO-09 }\end{array}$ & $\begin{array}{l}\text { Strong SO2 } \\
\text { Flash Drum }\end{array}$ & 2200 & 6600 & Horizontal & 24 & 100 & $316 \mathrm{LSS}$ & SAD-203 & \\
\hline $\begin{array}{l}\text { HPS-SAD } \\
\text { KO-10 }\end{array}$ & $\begin{array}{l}\text { Weak SO2 } \\
\text { Flash Drum }\end{array}$ & 1500 & 4500 & Horizontal & 84 & 100 & $316 \mathrm{LSS}$ & SAD-203 & \\
\hline $\begin{array}{l}\text { HPS-SAD } \\
\text { KO-11 }\end{array}$ & $\begin{array}{l}\text { Oxygen SO2 } \\
\text { Knockout Drum }\end{array}$ & 1400 & 4200 & Vertical & 84 & 100 & $316 \mathrm{LSS}$ & SAD-203 & \\
\hline $\begin{array}{l}\text { HPS-SAD } \\
\text { KO-12 }\end{array}$ & $\begin{array}{l}\text { EJ-01 } \\
\text { KO Drum }\end{array}$ & 2800 & 8400 & Vertical & $\begin{array}{l}3.5 \\
\text { iFV }\end{array}$ & 100 & $316 \mathrm{LSS}$ & SAD-205 & \\
\hline $\begin{array}{l}\text { HPS-SAD } \\
\text { KO-13 }\end{array}$ & $\begin{array}{l}\text { SO2 Compressor 3rd } \\
\text { Stage KO Drum }\end{array}$ & 1000 & 3000 & Vertical & 24 & 100 & $316 \mathrm{LSS}$ & SAD-206 & \\
\hline $\begin{array}{l}\text { HPS-SAD } \\
\text { KO-14 }\end{array}$ & $\begin{array}{l}\text { EJ-02 } \\
\text { KO Drum }\end{array}$ & 1400 & 4900 & Vertical & $\begin{array}{c}3.5 \\
\text { iFV }\end{array}$ & 100 & $316 \mathrm{LSS}$ & SAD-205 & \\
\hline
\end{tabular}

Table 11-6 Sulfuric Acid Decomposition Section Vessels/Reactors, cont'd

\begin{tabular}{|c|c|c|c|c|c|c|c|c|c|}
\hline \multicolumn{10}{|c|}{ EQUIPMENT LIST - VESSELS / REACTORS } \\
\hline \multicolumn{5}{|c|}{ Client: Westinghouse Electric Company } & \multicolumn{5}{|c|}{ Signature: TGS } \\
\hline \multicolumn{5}{|c|}{ Unit: Hybrid Sulfur TCA } & \multicolumn{5}{|c|}{ Location: Pittsburgh, PA } \\
\hline \multirow[b]{2}{*}{ Item No. } & \multirow[b]{2}{*}{ Name } & \multirow{2}{*}{$\begin{array}{l}\text { Diameter } \\
(\mathrm{mm})\end{array}$} & \multirow{2}{*}{$\begin{array}{l}\text { Length } \\
(\mathrm{mm})\end{array}$} & \multirow{2}{*}{$\begin{array}{l}\text { Horizon/ } \\
\text { Vertical }\end{array}$} & \multicolumn{2}{|c|}{ Mechanical Design } & \multirow{2}{*}{$\begin{array}{l}\text { Material } \\
\text { C.A. }(\mathrm{mm})\end{array}$} & \multirow[b]{2}{*}{ PFD } & \multirow[b]{2}{*}{ Remarks } \\
\hline & & & & & $\begin{array}{l}\text { Pressure } \\
\text { (barg) }\end{array}$ & Temp $\left({ }^{\circ} \mathrm{C}\right)$ & & & \\
\hline $\begin{array}{l}\text { HPS-SAD } \\
\text { KO-17 }\end{array}$ & $\begin{array}{l}\text { Condensate } \\
\text { Surge Pot }\end{array}$ & 1000 & 3000 & Horizontal & $\begin{array}{l}3.5 \\
/ F V\end{array}$ & 125 & 316 L SS & SAD-205 & \\
\hline $\begin{array}{l}\text { HPS-SAD } \\
\text { KO-20 }\end{array}$ & $\begin{array}{l}\text { SO2 Compressor 1st } \\
\text { Stage KO Drum }\end{array}$ & 2800 & 3100 & Vertical & 5 & 100 & $316 \mathrm{~L}$ SS & SAD-206 & \\
\hline $\begin{array}{l}\text { HPS-SAD } \\
\text { KO-21 }\end{array}$ & $\begin{array}{l}\text { SO2 Compressor 2nd } \\
\text { Stage KO Drum }\end{array}$ & 1400 & 4800 & Vertical & 10 & 100 & 316 L SS & SAD-206 & \\
\hline $\begin{array}{l}\text { HPS-SAD } \\
\text { KO-23 }\end{array}$ & $\begin{array}{l}50 \% \text { Acid Flash } \\
\text { Drum }\end{array}$ & 3700 & 8800 & Vertical & $\begin{array}{l}3.5 \\
/ \mathrm{FV}\end{array}$ & 100 & $\begin{array}{c}20 \mathrm{Cb} 3 \\
\text { Clad CS }\end{array}$ & SAD-201 & \\
\hline $\begin{array}{l}\text { HPS-SAD } \\
\text { KO-24 }\end{array}$ & $\begin{array}{c}65 \% \text { Acid } \\
\text { Flash Drum }\end{array}$ & 3000 & 8800 & Vertical & $\begin{array}{l}3.5 \\
/ F V\end{array}$ & 130 & $\begin{array}{l}\text { Alloy B3 } \\
\text { Clad CS }\end{array}$ & SAD-201 & \\
\hline $\begin{array}{c}\text { HPS-SAD } \\
\mathrm{KO}-25 \\
\mathrm{~A} / \mathrm{B} / \mathrm{C} / \mathrm{D}\end{array}$ & $\begin{array}{l}\text { Vacuum Column } \\
\text { Reflux Drum }\end{array}$ & 2100 & 5500 & Horizontal & $\begin{array}{l}3.5 \\
/ F V\end{array}$ & 145 & $316 \mathrm{~L}$ SS & SAD-202 & $\begin{array}{c}\text { One drum per TO-01 column train } \\
4 \text { trains }\end{array}$ \\
\hline $\begin{array}{l}\text { HPS-SAD } \\
\text { TK-01 }\end{array}$ & $\begin{array}{l}\text { Anolyte } \\
\text { Prep Tank }\end{array}$ & 4900 & 14600 & Horizontal & 22 & 115 & $\begin{array}{c}20 \mathrm{Cb} 3 \\
\text { Clad CS }\end{array}$ & SAD-204 & \\
\hline
\end{tabular}


Table 11-7 Sulfuric Acid Decomposition Section Pumps

\begin{tabular}{|c|c|c|c|c|c|c|c|c|c|}
\hline \multicolumn{10}{|c|}{ EQUIPMENT LIST - PUMPS } \\
\hline \multicolumn{5}{|c|}{ Client: Westinghouse Electric Company } & \multicolumn{5}{|c|}{ Signature: TGS } \\
\hline \multicolumn{5}{|c|}{ Unit: Hybrid Sulfur TCA } & \multicolumn{5}{|c|}{ Location: Pittsburgh, PA } \\
\hline \multirow{2}{*}{ Item No. } & \multirow{2}{*}{ Name } & \multirow{2}{*}{ Type } & \multirow{2}{*}{$\begin{array}{l}\text { Rated } \\
\text { Flow } \\
\left(\mathrm{m}^{3} / \mathrm{h}\right)\end{array}$} & \multirow{2}{*}{$\begin{array}{l}\text { Differential } \\
\text { Pressure } \\
\text { (bar) }\end{array}$} & \multirow{2}{*}{$\begin{array}{c}\text { Motor } \\
\mathrm{KW}\end{array}$} & \multicolumn{2}{|c|}{ Material } & \multirow{2}{*}{ PFD } & \multirow{2}{*}{ Remarks } \\
\hline & & & & & & Casing & Impeller & & \\
\hline $\begin{array}{c}\text { HPS-SAD } \\
\text { PP-02 } \\
\text { A/B/C/D/E }\end{array}$ & $\begin{array}{l}\text { Reactor Feed } \\
\text { Pump }\end{array}$ & $\begin{array}{l}\text { Multi- } \\
\text { stage } \\
\text { Centrif. }\end{array}$ & 150 & 91 & 550 & Alloy B3 & Alloy B3 & SAD-202 & $78 \%$ Efficiency \\
\hline $\begin{array}{l}\text { HPS-SAD } \\
\text { PP-03 A/B }\end{array}$ & $\begin{array}{c}\text { Anolyte } \\
\text { Booster Pump }\end{array}$ & Centrif. & 1040 & 2.5 & 110 & $20 \mathrm{Cb} 3$ & $20 \mathrm{Cb} 3$ & SAD-204 & $83.4 \%$ Efficiency \\
\hline $\begin{array}{l}\text { HPS-SAD } \\
\text { PP-04A/B }\end{array}$ & $\begin{array}{c}1^{\text {st }} \text { Stage } \\
\text { Discharge Pump }\end{array}$ & Rotary & 2 & 22 & 5.5 & $316 \mathrm{~L} \mathrm{SS}$ & $316 \mathrm{~L}$ SS & SAD-206 & $29.6 \%$ Efficiency \\
\hline $\begin{array}{l}\text { HPS-SAD } \\
\text { PP-05A/B }\end{array}$ & $\begin{array}{c}2^{\text {nd }} \text { Stage } \\
\text { Discharge Pump }\end{array}$ & $\begin{array}{l}\text { Multi- } \\
\text { stage } \\
\text { Centrif. }\end{array}$ & 45 & 16 & 45 & $316 \mathrm{~L} \mathrm{SS}$ & $316 \mathrm{~L}$ SS & SAD-206 & $62.3 \%$ Efficiency \\
\hline $\begin{array}{l}\text { HPS-SAD } \\
\text { PP-06 AVB }\end{array}$ & $\begin{array}{c}\text { EJ-01 } \\
\text { Condensate Pump }\end{array}$ & $\begin{array}{l}\text { Multi- } \\
\text { stage } \\
\text { Centrif. }\end{array}$ & 60 & 24 & 75 & $316 \mathrm{~L} \mathrm{SS}$ & $316 \mathrm{~L}$ SS & SAD-205 & $65.6 \%$ Efficiency \\
\hline $\begin{array}{l}\text { HPS-SAD } \\
\text { PP-07 A/B }\end{array}$ & $\begin{array}{c}\text { EJ-02 } \\
\text { Condensate Pump }\end{array}$ & $\begin{array}{l}\text { Multi- } \\
\text { stage } \\
\text { Centrif. }\end{array}$ & 18 & 25 & 30 & CS & CS & SAD-205 & $51.0 \%$ Efficiency \\
\hline $\begin{array}{l}\text { HPS-SAD } \\
\text { PP-08 } \\
\text { A/B/C/D/E }\end{array}$ & $\begin{array}{l}\text { Vacuum Column } \\
\text { Reflux/Overhead } \\
\text { Product Pump }\end{array}$ & $\begin{array}{l}\text { Multi- } \\
\text { stage } \\
\text { Centrif. }\end{array}$ & 70 & 25 & 250 & $316 \mathrm{~L} \mathrm{SS}$ & $316 \mathrm{~L}$ SS & SAD-202 & $72 \%$ Efficiency \\
\hline $\begin{array}{l}\text { HPS-SAD } \\
\text { PP-09A/B }\end{array}$ & $\begin{array}{c}\text { KO-17 } \\
\text { Condensate Pump }\end{array}$ & $\begin{array}{c}\text { Dia- } \\
\text { phragm }\end{array}$ & 1 & 1 & .55 & $316 \mathrm{~L} \mathrm{SS}$ & $316 \mathrm{~L}$ SS & SAD-205 & $29.6 \%$ Efficiency \\
\hline
\end{tabular}

Table 11-7 Sulfuric Acid Decomposition Section Pumps, cont'd

\begin{tabular}{|c|c|c|c|c|c|c|c|c|c|}
\hline \multicolumn{10}{|c|}{ EQUIPMENT LIST - PUMPS } \\
\hline \multicolumn{5}{|c|}{ Client: Westinghouse Electric Company } & \multicolumn{5}{|c|}{ Signature: TGS } \\
\hline \multicolumn{5}{|c|}{ Unit: Hybrid Sulfur TCA } & \multicolumn{5}{|c|}{ Location: Pittsburgh, PA } \\
\hline \multirow{2}{*}{ Item No. } & \multirow{2}{*}{ Name } & \multirow{2}{*}{ Type } & \multirow{2}{*}{$\begin{array}{l}\text { Rated } \\
\text { Flow } \\
\left(\mathrm{m}^{3} / \mathrm{h}\right)\end{array}$} & \multirow{2}{*}{$\begin{array}{l}\text { Differential } \\
\text { Pressure } \\
\text { (bar) }\end{array}$} & \multirow{2}{*}{$\begin{array}{c}\text { Motor } \\
\mathrm{KW}\end{array}$} & \multicolumn{2}{|c|}{ Material } & \multirow{2}{*}{ PFD } & \multirow{2}{*}{ Remarks } \\
\hline & & & & & & Casing & Impeller & & \\
\hline $\begin{array}{c}\text { HPS-SAD } \\
\text { PP-11 } \\
\text { A/B/C/D/E }\end{array}$ & $\begin{array}{c}\text { Anolyte } \\
\text { Recirculation Pump }\end{array}$ & Centrif. & 805 & 2.5 & 75 & $20 \mathrm{Cb} 3$ & $20 \mathrm{Cb} 3$ & SAD-204 & $86 \%$ Efficiency \\
\hline $\begin{array}{l}\text { HPS-SAD } \\
\text { PP-23 AVB }\end{array}$ & $\begin{array}{c}50 \% \text { Acid } \\
\text { Booster Pump }\end{array}$ & Centrif. & 450 & 1 & 22 & $20 \mathrm{Cb} 3$ & $20 \mathrm{Cb} 3$ & SAD-201 & $84 \%$ Efficiency \\
\hline $\begin{array}{l}\text { HPS-SAD } \\
\text { PP-24 }\end{array}$ & $\begin{array}{c}65 \% \text { Acid } \\
\text { Booster Pump }\end{array}$ & Centrif. & 610 & 4 & 90 & Alloy B3 & Alloy B3 & SAD-201 & $85 \%$ Efficiency \\
\hline
\end{tabular}

Table 11-8 Sulfuric Acid Decomposition Section Compressors/Blowers/Vacuum Pumps

\begin{tabular}{|c|c|c|c|c|c|c|c|c|c|c|}
\hline \multicolumn{11}{|c|}{ EQUIPMENT LIST - COMPRESSORS / BLOWERS / VACUUM PUMPS } \\
\hline \multicolumn{6}{|c|}{ Client: Westinghouse Electric Company } & \multicolumn{5}{|c|}{ Signature: TGS } \\
\hline \multicolumn{6}{|c|}{ Unit: Hybrid Sulfur TCA } & \multicolumn{5}{|c|}{ Location: Pittsburgh, PA } \\
\hline \multirow[b]{2}{*}{ Item No. } & \multirow[b]{2}{*}{ Name } & \multirow[b]{2}{*}{ Type } & \multirow[b]{2}{*}{$\begin{array}{l}\text { Capacity } \\
\left(\mathrm{Am}^{3} / \mathrm{h}\right)\end{array}$} & \multirow{2}{*}{$\begin{array}{l}\text { Suction } \\
\text { Pressure } \\
\text { (bar a) }\end{array}$} & \multirow{2}{*}{$\begin{array}{l}\text { Differential } \\
\text { Pressure } \\
\text { (bar) }\end{array}$} & \multicolumn{2}{|c|}{ Driver } & \multirow[b]{2}{*}{$\begin{array}{l}\text { Material } \\
\text { C.A. }(\mathrm{mm})\end{array}$} & \multirow[b]{2}{*}{ PFD } & \multirow[b]{2}{*}{ Remarks } \\
\hline & & & & & & Type & $\begin{array}{l}\text { Rated } \\
\text { Power } \\
\text { (kW) }\end{array}$ & & & \\
\hline $\begin{array}{l}\text { HPS-SAD } \\
\text { EJ-01 }\end{array}$ & $\begin{array}{l}\text { KO-14 } \\
\text { Ejector }\end{array}$ & $\begin{array}{l}\text { Steam } \\
\text { Ejector }\end{array}$ & 6750 & 0.3 & 0.8 & - & - & $316 \mathrm{~L}$ SS & SAD-205 & \\
\hline $\begin{array}{l}\text { HPS-SAD } \\
\text { EJ-02 }\end{array}$ & $\begin{array}{c}\text { Vacuum } \\
\text { Column Ejector }\end{array}$ & $\begin{array}{l}\text { Steam } \\
\text { Ejector }\end{array}$ & 4465 & 0.090 & 0.3 & - & - & $316 \mathrm{~L}$ SS & SAD-205 & \\
\hline $\begin{array}{c}\text { HPS-SAD } \\
\text { CO-01 }\end{array}$ & $\begin{array}{l}\text { SO2 Recycle } \\
\text { Compressor }\end{array}$ & $\begin{array}{l}\text { Three } \\
\text { Stage } \\
\text { Centrif. }\end{array}$ & 31506 & 1.01 & 20.3 & Electric & 3200 & $316 \mathrm{~L}$ SS & SAD-206 & \\
\hline
\end{tabular}


Table 11-9 Sulfuric Acid Decomposition Section Heat Exchangers

\begin{tabular}{|c|c|c|c|c|c|c|c|}
\hline \multicolumn{8}{|c|}{ EQUIPMENT LIST - HEAT EXCHANGERS } \\
\hline \multicolumn{3}{|c|}{ Client: Westinghouse Electric Company } & & & \multicolumn{3}{|c|}{ Signature: TGS } \\
\hline \multicolumn{4}{|c|}{ Unit: Hybrid Sulfur TCA } & & \multicolumn{3}{|c|}{ Location: Pittsburgh, PA } \\
\hline \multirow{3}{*}{ Item No. } & \multirow{3}{*}{ Name } & \multirow{3}{*}{$\begin{array}{c}\text { Area } \\
\left(\mathrm{m}^{2}\right)\end{array}$} & \multicolumn{2}{|c|}{ Mechanical Design } & \multirow{3}{*}{ Type } & \multirow{3}{*}{ PFD } & \multirow{3}{*}{ Remarks } \\
\hline & & & Shell & Tube & & & \\
\hline & & & $\begin{array}{c}\text { Material } \\
\text { Pressure (bar g) } \\
\text { Temperature } \\
\left({ }^{\circ} \mathrm{C}\right) \\
\end{array}$ & $\begin{array}{c}\text { Material } \\
\text { Pressure (bar g) } \\
\text { Temperature } \\
\left({ }^{\circ} \mathrm{C}\right) \\
\end{array}$ & & & \\
\hline $\begin{array}{l}\text { HPS-SAD } \\
\text { CO-01 HX1 }\end{array}$ & $\begin{array}{l}1^{\text {st }} \text { Stage } \\
\text { Aftercooler }\end{array}$ & 240 & $\begin{array}{c}316 \mathrm{~L} \text { SS } \\
23 \\
181\end{array}$ & $\begin{array}{c}\text { CS/ 316L SS } \\
17 \\
100 \\
\end{array}$ & BEU & SAD-206 & \\
\hline $\begin{array}{l}\text { HPS-SAD } \\
\text { CO-01 HX2 }\end{array}$ & $\begin{array}{l}2^{\text {nd }} \text { Stage } \\
\text { Aftercooler }\end{array}$ & 950 & $\begin{array}{c}316 \mathrm{~L} \text { SS } \\
23 \\
200\end{array}$ & $\begin{array}{c}\text { CS/ 316L SS } \\
17 \\
100 \\
\end{array}$ & BEU & SAD-206 & \\
\hline $\begin{array}{l}\text { HPS-SAD } \\
\text { CO- } 01 \mathrm{HX} 3\end{array}$ & $\begin{array}{l}3^{\text {rd }} \text { Stage } \\
\text { Aftercooler }\end{array}$ & 140 & $\begin{array}{c}316 \text { L SS } \\
23 \\
182\end{array}$ & $\begin{array}{c}\text { CS/ 316L SS } \\
17 \\
100\end{array}$ & BEU & SAD-206 & \\
\hline $\begin{array}{c}\text { HPS-SAD } \\
\text { HX-02 } \\
\text { A/B/C/D }\end{array}$ & $\begin{array}{l}50 \% \text { Acid Feed } \\
\text { Preheater }\end{array}$ & 135 & $\begin{array}{l}\text { CS } \\
9.5 \\
200 \\
\end{array}$ & $\begin{array}{c}20 \mathrm{Cb} 3 \\
7.5 \\
125 \\
\end{array}$ & BEU & SAD-202 & $\begin{array}{l}\text { One shell per TO-01 train; area shown } \\
\text { is for } 4 \text { trains }\end{array}$ \\
\hline $\begin{array}{c}\text { HPS-SAD } \\
\mathrm{HX}-03 \\
\mathrm{~A} / \mathrm{B} / \mathrm{C} / \mathrm{D}\end{array}$ & $\begin{array}{c}65 \% \text { Acid Feed } \\
\text { Preheater }\end{array}$ & 95 & $\begin{array}{l}\text { CS } \\
9.5 \\
200 \\
\end{array}$ & $\begin{array}{c}\text { Alloy B3 } \\
7.5 \\
145\end{array}$ & BEU & SAD-202 & $\begin{array}{l}\text { One shell per TO-01 train; area shown } \\
\text { is for } 4 \text { trains }\end{array}$ \\
\hline $\begin{array}{l}\text { HPS-SAD } \\
\text { HX-04 A-1 }\end{array}$ & $\begin{array}{l}\text { Reactor } \mathrm{O} / \mathrm{H} \\
\text { Condenser \#1 }\end{array}$ & 815 & $\begin{array}{c}316 \text { L SS } \\
83 \\
275\end{array}$ & $\begin{array}{c}\text { AlloyB3 } \\
64 \\
130\end{array}$ & DEU & SAD-203 & \\
\hline
\end{tabular}

Table 11-9 Sulfuric Acid Decomposition Section Heat Exchangers, cont'd

\begin{tabular}{|c|c|c|c|c|c|c|c|}
\hline \multicolumn{8}{|c|}{ EQUIPMENT LIST - HEAT EXCHANGERS } \\
\hline \multicolumn{5}{|c|}{ Client: Westinghouse Electric Company } & \multicolumn{3}{|c|}{ Signature: TGS } \\
\hline \multicolumn{5}{|c|}{ Unit: Hybrid Sulfur TCA } & \multicolumn{3}{|c|}{ Location: Pittsburgh, PA } \\
\hline \multirow{3}{*}{ Item No. } & \multirow{3}{*}{ Name } & \multirow{3}{*}{$\begin{array}{c}\begin{array}{c}\text { Area } \\
\left(\mathrm{m}^{2}\right)\end{array} \\
(\text { Total) }\end{array}$} & \multicolumn{2}{|c|}{ Mechanical Design } & \multirow{3}{*}{ Type } & \multirow{3}{*}{ PFD } & \multirow{3}{*}{ Remarks } \\
\hline & & & Shell & Tube & & & \\
\hline & & & $\begin{array}{c}\text { Material } \\
\text { Pressure (bar g) } \\
\text { Temperature } \\
\left({ }^{\circ} \mathrm{C}\right)\end{array}$ & $\begin{array}{c}\text { Material } \\
\text { Pressure (bar g) } \\
\text { Temperature } \\
\left({ }^{\circ} \mathrm{C}\right)\end{array}$ & & & \\
\hline $\begin{array}{l}\text { HPS-SAD } \\
\text { HX-04 A-2 }\end{array}$ & $\begin{array}{c}\text { Reactor } \mathrm{O} / \mathrm{H} \\
\text { Condenser \#2 }\end{array}$ & 275 & $\begin{array}{c}20 \mathrm{Cb} 3 \mathrm{~b} \text { Clad CS } \\
83 \\
275\end{array}$ & $\begin{array}{c}316 \mathrm{~L} \text { ss/ 20CB3 } \\
64 \\
100\end{array}$ & DEU & SAD-203 & \\
\hline $\begin{array}{l}\text { HPS-SAD } \\
\text { HX-04B }\end{array}$ & $\begin{array}{c}\text { Reactor } \mathrm{O} / \mathrm{H} \\
\text { Condenser \#3 }\end{array}$ & 310 & $\begin{array}{c}20 \mathrm{Cb} 3 \mathrm{~b} \text { Clad CS } \\
83 \\
275\end{array}$ & $\begin{array}{c}316 \mathrm{~L} \mathrm{sS} / 20 \mathrm{CB} 3 \\
64 \\
100\end{array}$ & DEU & SAD-203 & \\
\hline $\begin{array}{l}\text { HPS-SAD } \\
\text { HX-04C }\end{array}$ & $\begin{array}{l}\text { Reactor } \mathrm{O} / \mathrm{H} \\
\text { Trim Cooler }\end{array}$ & 315 & $\begin{array}{c}316 \text { L SS } \\
83 \\
275\end{array}$ & $\begin{array}{c}316 \text { L SS } \\
64 \\
100\end{array}$ & DEU & SAD-203 & \\
\hline $\begin{array}{l}\text { HPS-SAD } \\
\text { HX-07 }\end{array}$ & $\begin{array}{l}\text { KO-02 O/Head } \\
\text { Vapor Cooler }\end{array}$ & 850 & $\begin{array}{c}316 \text { L SS } \\
6.5 \\
115\end{array}$ & $\begin{array}{c}316 \mathrm{~L} \text { SS } \\
9.0 \\
100\end{array}$ & BEU & SAD-201 & \\
\hline $\begin{array}{l}\text { HPS-SAD } \\
\text { HX-08A }\end{array}$ & $\begin{array}{c}\text { KO-06 Vapor } \\
\text { Cooler }\end{array}$ & 2400 & $\begin{array}{c}316 \mathrm{~L} \text { SS } \\
3.5 \\
175\end{array}$ & $\begin{array}{c}20 \mathrm{Cb} 3 \\
5.0 \\
100\end{array}$ & BEU & SAD-201 & \\
\hline $\begin{array}{l}\text { HPS-SAD } \\
\text { HX-08B }\end{array}$ & $\begin{array}{c}\text { KO-06 } \\
\text { Condenser }\end{array}$ & 1600 & $\begin{array}{c}316 \mathrm{~L} \text { SS } \\
3.5 \\
175\end{array}$ & $\begin{array}{c}20 \mathrm{Cb} 3 \\
5.0 \\
100\end{array}$ & BEU & SAD-201 & \\
\hline
\end{tabular}


Table 11-9 Sulfuric Acid Decomposition Section Heat Exchangers, cont'd

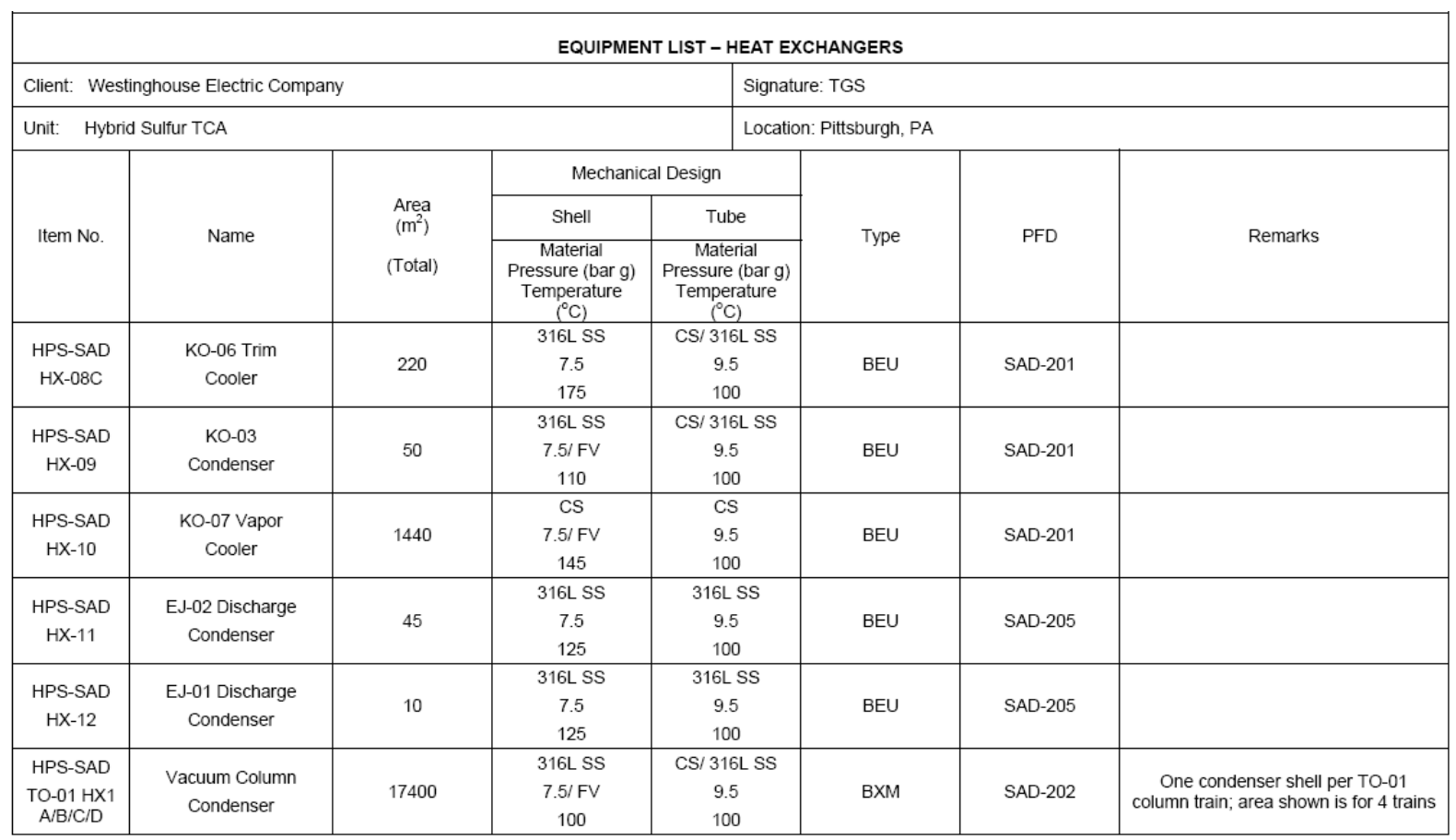

Table 11-9 Sulfuric Acid Decomposition Section Heat Exchangers, cont'd

\begin{tabular}{|c|c|c|c|c|c|c|c|}
\hline \multicolumn{8}{|c|}{ EQUIPMENT LIST - HEAT EXCHANGERS } \\
\hline \multicolumn{5}{|c|}{ Client: Westinghouse Electric Company } & \multicolumn{3}{|c|}{ Signature: TGS } \\
\hline \multicolumn{4}{|c|}{ Unit: Hybrid Sulfur TCA } & \multicolumn{4}{|c|}{ Location: Pittsburgh, PA } \\
\hline \multirow{3}{*}{ Item No. } & \multirow{3}{*}{ Name } & \multirow{3}{*}{$\begin{array}{l}\text { Area } \\
\left(\mathrm{m}^{2}\right) \\
\text { (Total) }\end{array}$} & Mechani & Design & \multirow{3}{*}{ Type } & \multirow{3}{*}{ PFD } & \multirow{3}{*}{ Remarks } \\
\hline & & & Shell & Tube & & & \\
\hline & & & $\begin{array}{c}\text { Material } \\
\text { Pressure (bar g) } \\
\text { Temperature } \\
\left({ }^{\circ} \mathrm{C}\right) \\
\end{array}$ & $\begin{array}{c}\text { Material } \\
\text { Pressure (bar g) } \\
\text { Temperature } \\
\left({ }^{\circ} \mathrm{C}\right) \\
\end{array}$ & & & \\
\hline $\begin{array}{c}\text { HPS-SAD } \\
\text { TO-01 HX2 } \\
\text { A/B/C/D }\end{array}$ & $\begin{array}{l}\text { Vacuum Column } \\
\text { Reboiler }\end{array}$ & 2600 & $\begin{array}{l}\text { CS } \\
9.5 \\
200\end{array}$ & $\begin{array}{c}\text { Alloy B3 } \\
7.5 \\
100\end{array}$ & BEM & SAD-202 & $\begin{array}{l}\text { Onereboilerl per TO-01 column; area } \\
\text { shown is for } 4 \text { trains }\end{array}$ \\
\hline
\end{tabular}

\subsection{FEED AND UTILITY SUPPLY SECTION}

Table 11-10 Feed and Utility Supply Section Vessels/Reactors

\begin{tabular}{|c|c|c|c|c|c|c|c|c|c|}
\hline \multicolumn{10}{|c|}{ EQUIPMENT LIST - VESSELS / REACTORS } \\
\hline \multicolumn{5}{|c|}{ Client: Westinghouse Electric Company } & \multicolumn{5}{|c|}{ Signature: $C O B$} \\
\hline \multicolumn{5}{|c|}{ Unit: Hybrid Sulfur TCA } & \multicolumn{5}{|c|}{ Location: Pittsburgh, PA } \\
\hline \multirow[b]{2}{*}{ Item No. } & \multirow[b]{2}{*}{ Name } & \multirow[b]{2}{*}{$\begin{array}{c}\text { Diameter } \\
(\mathrm{mm})\end{array}$} & \multirow[b]{2}{*}{$\begin{array}{l}\text { Length } \\
(\mathrm{mm})\end{array}$} & \multirow{2}{*}{$\begin{array}{l}\text { Horizon/ } \\
\text { Vertical }\end{array}$} & \multicolumn{2}{|c|}{ Mechanical Design } & \multirow{2}{*}{$\begin{array}{l}\text { Material } \\
\text { C.A. (mm) }\end{array}$} & \multirow[b]{2}{*}{ PFD } & \multirow[b]{2}{*}{ Remarks } \\
\hline & & & & & $\begin{array}{l}\text { Pressure } \\
\text { bar }(\mathbf{g})\end{array}$ & $\begin{array}{l}\text { Temp } \\
\left({ }^{\circ} \mathrm{C}\right)\end{array}$ & & & \\
\hline $\begin{array}{l}\text { HPS-FUS } \\
\text { KO- } 51\end{array}$ & $\begin{array}{l}\text { Sulfuric Acld } \\
\text { Degassing Drum }\end{array}$ & 3000 & 9000 & Vertical & 20 & 100 & TFE Lined & FUS-101 & \\
\hline
\end{tabular}


Table 11-11 Feed and Utility Supply Section Low Pressure Tanks

\begin{tabular}{|c|c|c|c|c|c|c|c|c|}
\hline \multicolumn{9}{|c|}{ EQUIPMENT LIST - LOW PRESSURE TANKS } \\
\hline \multicolumn{5}{|c|}{ Client: Westinghouse Electric Company } & \multicolumn{4}{|l|}{ Signature: TGS } \\
\hline \multicolumn{5}{|c|}{ Unit: Hybrid Sulfur TCA } & \multicolumn{4}{|c|}{ Location: Pittsburgh, PA } \\
\hline \multirow[b]{2}{*}{ Item No. } & \multirow[b]{2}{*}{ Name } & \multirow{2}{*}{$\begin{array}{l}\text { Diameter } \\
(\mathrm{mm})\end{array}$} & \multirow{2}{*}{$\begin{array}{l}\text { Height } \\
(\mathrm{mm})\end{array}$} & \multicolumn{2}{|c|}{ Mechanical Design } & \multirow{2}{*}{$\begin{array}{l}\text { Material } \\
\text { C.A. }(\mathrm{mm})\end{array}$} & \multirow[b]{2}{*}{ PFD } & \multirow[b]{2}{*}{ Remarks } \\
\hline & & & & Pressure & $\begin{array}{c}\text { Temperature } \\
\left({ }^{\circ} \mathrm{C}\right)\end{array}$ & & & \\
\hline $\begin{array}{l}\text { HPS-FUS } \\
\text { MT-51 }\end{array}$ & $\begin{array}{c}\mathrm{H} 2 \mathrm{SO} 4 \text { Storage } \\
\text { Tank }\end{array}$ & 24000 & 12800 & $\begin{array}{c}203 \mathrm{~mm} \\
\text { WG }\end{array}$ & 70 & TFE Lined & FUS-101 & \\
\hline $\begin{array}{l}\text { HPS-FUS } \\
\text { MT-52 }\end{array}$ & $\begin{array}{c}\text { Caustic Storage } \\
\text { Tank }\end{array}$ & 6000 & 7500 & $\begin{array}{c}203 \mathrm{~mm} \\
\text { WG }\end{array}$ & 70 & CS & FUS-101 & \\
\hline $\begin{array}{c}\text { HPS-FUS } \\
\text { MT-53 }\end{array}$ & $\begin{array}{l}\text { Treated Water } \\
\text { Storage Tank }\end{array}$ & 21600 & 12800 & $\begin{array}{c}203 \mathrm{~mm} \\
\text { WG }\end{array}$ & 70 & cs & FUS-102 & \\
\hline
\end{tabular}

Table 11-12 Feed and Utility Supply Section Pumps

\begin{tabular}{|c|c|c|c|c|c|c|c|c|c|}
\hline \multicolumn{10}{|c|}{ EQUIPMENT LIST - PUMPS } \\
\hline \multicolumn{5}{|c|}{ Client: Westinghouse Electric Company } & \multicolumn{5}{|c|}{ Signature: TGS } \\
\hline \multicolumn{5}{|c|}{ Unit: Hybrid Sulfur TCA } & \multicolumn{5}{|c|}{ Location: Pittsburgh. PA } \\
\hline \multirow{2}{*}{ Item No. } & \multirow{2}{*}{ Name } & \multirow{2}{*}{ Type } & \multirow{2}{*}{$\begin{array}{l}\text { Rated } \\
\text { Flow } \\
\left(\mathrm{m}^{3} / \mathrm{h}\right)\end{array}$} & \multirow{2}{*}{$\begin{array}{c}\text { Differential } \\
\text { Pressure } \\
\text { (bar) }\end{array}$} & \multirow{2}{*}{$\begin{array}{c}\text { Motor } \\
\mathrm{kW}\end{array}$} & \multicolumn{2}{|c|}{ Material } & \multirow{2}{*}{ PFD } & \multirow{2}{*}{ Remarks } \\
\hline & & & & & & Casing & Impeller & & \\
\hline $\begin{array}{l}\text { HPS-FUS } \\
\text { PP-51 A/B }\end{array}$ & $\begin{array}{c}\mathrm{H} 2 \mathrm{SO} 4 \\
\text { Make-Up Pump }\end{array}$ & Centrif. & 15 & 2 & 2.2 & $20 \mathrm{CB} 3$ & $20 \mathrm{CB} 3$ & FUS-101 & $54 \%$ Efficient \\
\hline $\begin{array}{l}\text { HPS-FUS } \\
\text { PD-52A/B }\end{array}$ & $\begin{array}{l}\text { H2SO4 Feed } \\
\text { Pump }\end{array}$ & Rotary & 1.5 & 25 & 5.5 & $20 \mathrm{CB} 3$ & $20 C B 3$ & FUS-101 & $65 \%$ Efficlent \\
\hline $\begin{array}{l}\text { HPS-FUS } \\
\text { PP-53 A/B }\end{array}$ & $\begin{array}{l}\mathrm{NaOH} \text { Make-up } \\
\text { Pump }\end{array}$ & Centrif. & 15 & 2 & 2.2 & CS & CS & FUS-101 & $54 \%$ Efficient \\
\hline $\begin{array}{l}\text { HPS-FUS } \\
\text { PD-54 A/B }\end{array}$ & $\begin{array}{l}\mathrm{NaOH} \text { Solution } \\
\text { Supply Pump }\end{array}$ & Rotary & 2 & 25 & 7.5 & CS & cs & FUS-101 & $65 \%$ Efficient \\
\hline $\begin{array}{l}\text { HPS-FUS } \\
\text { PP-55A/B }\end{array}$ & $\begin{array}{c}\text { Water Transfer } \\
\text { Pumps }\end{array}$ & Centrif. & 70 & 24 & 75 & CS & cs & FUS-102 & $72 \%$ Efficient \\
\hline
\end{tabular}

Table 11-13 Feed and Utility Supply Section Miscellaneous Equipment

\begin{tabular}{|c|c|c|c|c|}
\hline \multicolumn{3}{|c|}{ EQUIPMENT LIST - MISCELLANEOUS } \\
\hline \multicolumn{2}{|c|}{} & \multicolumn{2}{l|}{ Signature: TGS } \\
\hline \multicolumn{2}{|c|}{ Client: Westinghouse Electric Company } & \multicolumn{2}{l|}{ Location: Pittsburgh, PA } \\
\hline $\begin{array}{c}\text { Unit: Hybrid Sulfur TCA } \\
\text { Item No. }\end{array}$ & Material & PFD & Duty - Description - Remarks \\
\hline $\begin{array}{c}\text { HPS-FUS } \\
\text { GZ-101 }\end{array}$ & Water Treatment Package Unit & By Vendor & FUS-102 & $\begin{array}{c}\text { Fully assembled enclosed skid } \\
\text { S1,000,000 vendor quote, minimal installation 4m } \times 12 \mathrm{~m} \text { pad } \\
\text { required }\end{array}$ \\
\hline
\end{tabular}


Table 11-14 Feed and Utility Supply Section Heat Exchangers

\begin{tabular}{|c|c|c|c|c|c|c|c|}
\hline \multicolumn{8}{|c|}{ EQUIPMENT LIST - HEAT EXCHANGERS } \\
\hline \multicolumn{5}{|c|}{ Client: Westinghouse Electric Company } & \multicolumn{3}{|c|}{ Signature: TGS } \\
\hline \multicolumn{4}{|c|}{ Unit: Hybrid Sulfur TCA } & & \multicolumn{3}{|c|}{ Location: Pittsburgh, PA } \\
\hline \multirow{3}{*}{ Item No. } & \multirow{3}{*}{ Name } & \multirow{3}{*}{$\begin{array}{l}\text { Area } \\
\left(\mathrm{m}^{2}\right)\end{array}$} & \multicolumn{2}{|c|}{ Mechanical Design } & \multirow{3}{*}{ Type } & \multirow{3}{*}{ PFD } & \multirow{3}{*}{ Remarks } \\
\hline & & & Shell & Tube & & & \\
\hline & & & $\begin{array}{c}\text { Material } \\
\text { Pressure (bar g) } \\
\text { Temperature } \\
\text { ( } \mathrm{C} \text { ) }\end{array}$ & $\begin{array}{c}\text { Material } \\
\text { Pressure (bar g) } \\
\text { Temperature } \\
\left({ }^{\circ} \mathrm{C}\right) \\
\end{array}$ & & & \\
\hline $\begin{array}{l}\text { HPS-FUS } \\
\text { HX-51 }\end{array}$ & $\begin{array}{l}\text { H2SO4 Storage } \\
\text { Tank Heater/Cooler }\end{array}$ & 1050 & $\begin{array}{c}\text { CS } \\
3 \\
150\end{array}$ & $\begin{array}{c}20 \mathrm{CB} 3 \\
30 \\
90\end{array}$ & BEU & FUS-101 & \\
\hline $\begin{array}{l}\text { HPS-FUS } \\
\text { HX-52 }\end{array}$ & $\begin{array}{l}\mathrm{NaOH} \text { Tank } \\
\text { Heater/Cooler }\end{array}$ & 2 & $\begin{array}{c}C S \\
3 \\
150\end{array}$ & $\begin{array}{l}\mathrm{CS} \\
23 \\
90\end{array}$ & Double Pipe & FUS-101 & \\
\hline
\end{tabular}

\subsection{PRODUCT PURIFICATION SECTION}

\section{Table 11-15 Product Purification Section Towers}

\begin{tabular}{|c|c|c|c|c|c|c|c|c|c|c|}
\hline \multicolumn{11}{|c|}{ EQUIPMENT LIST - TOWERS } \\
\hline \multicolumn{5}{|c|}{ Client: Westinghouse Electric Company } & \multicolumn{6}{|c|}{ Signature: TGS } \\
\hline \multicolumn{5}{|c|}{ Unit: Hybrid Sulfur TCA } & \multicolumn{6}{|c|}{ Location: Pittsburgh, PA } \\
\hline \multirow[b]{2}{*}{ Item No. } & \multirow[b]{2}{*}{ Name } & \multirow{2}{*}{$\begin{array}{c}\text { Diameter } \\
(\mathrm{mm})\end{array}$} & \multirow{2}{*}{$\begin{array}{l}\text { Height } \\
(\mathrm{mm})\end{array}$} & \multirow{2}{*}{$\begin{array}{c}\text { Packing/ } \\
\text { Trays }\end{array}$} & \multicolumn{2}{|c|}{ Mechanical Design } & \multicolumn{2}{|c|}{ Material } & \multirow[b]{2}{*}{ PFD } & \multirow[b]{2}{*}{ Remarks } \\
\hline & & & & & $\begin{array}{l}\text { Press } \\
\text { (bar g) }\end{array}$ & Temp $\left({ }^{\circ} \mathrm{C}\right)$ & $\begin{array}{c}\text { Shell } \\
\text { C.A. }(\mathrm{mm})\end{array}$ & $\begin{array}{l}\text { Packing } \\
\text { Trays }\end{array}$ & & \\
\hline $\begin{array}{c}\text { HPS-PPU } \\
\text { TO-03 }\end{array}$ & $\begin{array}{l}\text { SO2 Scrub } \\
\text { Tower }\end{array}$ & 2600 & 7000 & $\begin{array}{l}33.4 \mathrm{~m}^{3} \text { of } \\
\text { inch IMTP } \\
=25 \text { Packin }\end{array}$ & 27 & 100 & $\operatorname{cs}$ & CS & $\begin{array}{c}\text { PPU- } \\
403\end{array}$ & \\
\hline
\end{tabular}

Table 11-16 Product Purification Section Vessels/Reactors

\begin{tabular}{|c|c|c|c|c|c|c|c|c|c|}
\hline \multicolumn{10}{|c|}{ EQUIPMENT LIST - VESSELS / REACTORS } \\
\hline \multicolumn{5}{|c|}{ Client: Westinghouse Electric Company } & \multicolumn{5}{|c|}{ Signature: TGS } \\
\hline \multicolumn{5}{|c|}{ Unit: Hybrid Sulfur TCA } & \multicolumn{5}{|c|}{ Location: Pittsburgh, PA } \\
\hline \multirow[b]{2}{*}{ Item No. } & \multirow[b]{2}{*}{ Name } & \multirow{2}{*}{$\begin{array}{c}\text { Diameter } \\
(\mathrm{mm})\end{array}$} & \multirow{2}{*}{$\begin{array}{l}\text { Length } \\
(\mathrm{mm})\end{array}$} & \multirow{2}{*}{$\begin{array}{l}\text { Horizon/ } \\
\text { Vertical }\end{array}$} & \multicolumn{2}{|c|}{ Mechanical Design } & \multirow{2}{*}{$\begin{array}{l}\text { Material } \\
\text { C.A. }(\mathrm{mm})\end{array}$} & \multirow[b]{2}{*}{ PFD } & \multirow[b]{2}{*}{ Remarks } \\
\hline & & & & & $\begin{array}{c}\text { Pressure } \\
\text { (bar g) }\end{array}$ & Temp $\left({ }^{\circ} \mathrm{C}\right)$ & & & \\
\hline $\begin{array}{l}\text { HPS-PPU } \\
\text { RX-02 }\end{array}$ & Hydrogenator & 2600 & 3200 & Vertical & 53 & 400 & $\begin{array}{l}11 / / 4 \mathrm{Cr}, 1 / 2 \\
\mathrm{Mo}\end{array}$ & PPU-402 & $\begin{array}{l}13.6 \mathrm{~m}^{3} \text { CoMo hydrogenation } \\
\text { catalyst: } \$ 312.000 \text { per load }\end{array}$ \\
\hline $\begin{array}{l}\text { HPS-PPU } \\
\text { DR-01 A/B }\end{array}$ & $\begin{array}{l}\text { Hydrogen } \mathrm{H} 2 \mathrm{O} \\
\text { Adsorber }\end{array}$ & 3000 & 5800 & Vertical & 53 & 110 & cs & PPU -401 & $\begin{array}{c}2 \text { beds @ } 32.8 \mathrm{~m}^{3} \text { of } 3 \mathrm{~A} \text { mol sieve } \\
\$ 138,000 \text { per bed }\end{array}$ \\
\hline $\begin{array}{l}\text { HPS-PPU } \\
\text { DR-02 A\&B }\end{array}$ & $\begin{array}{l}\text { Oxygen } \mathrm{H}_{2} \mathrm{O} \\
\text { Adsorber }\end{array}$ & 2800 & 6000 & Vertical & 26 & 100 & CS & PPU -403 & $\begin{array}{c}2 \text { beds @ } 29.6 \mathrm{~m}^{3} \text { of } 3 \mathrm{~A} \text { mol sieve } \\
\$ 125,000 \text { per bed }\end{array}$ \\
\hline $\begin{array}{l}\text { HPS-PPU } \\
\text { DR-03 } \\
\text { A/B/C/D }\end{array}$ & Desulfurizer Beds & 3800 & 6000 & Vertical & 53 & 400 & $\begin{array}{l}11 / 4 \mathrm{Cr}, 1 / 2 \\
\mathrm{Mo} .\end{array}$ & PPU-402 & $\begin{array}{c}4 \text { beds @ } 54.4 \mathrm{~m}^{3} \text { of Zinc Oxide } \\
\$ 865.000 \text { per bed }\end{array}$ \\
\hline $\begin{array}{l}\text { HPS-PPU } \\
\text { DR-04 A/B }\end{array}$ & $\begin{array}{l}\text { Trace } \mathrm{H} 20 \\
\text { Adsorber }\end{array}$ & 1200 & 3600 & Vertical & 53 & 107 & CS & PPU-402 & $\begin{array}{c}2 \text { beds } 3.3 \mathrm{~m}^{3} \text { of } 3 \mathrm{~A} \text { mol sleve } \\
\$ 14,000 \text { per bed }\end{array}$ \\
\hline $\begin{array}{l}\text { HPS-PPU } \\
\text { DR-05 A\&B }\end{array}$ & SO2 Adsorber & 2800 & 6000 & Vertical & 26 & 100 & cs & PPU-403 & $\begin{array}{c}2 \text { beds @ } 29.6 \mathrm{~m}^{3} \text { of } 4 \mathrm{~A} \text { mol sieve } \\
\$ 114.000 \text { per bed }\end{array}$ \\
\hline $\begin{array}{l}\text { HPS-PPU } \\
\text { KO-26 }\end{array}$ & $\begin{array}{l}\text { Hydrogen Compressor } \\
\text { Discharge Drum }\end{array}$ & 1000 & 2600 & Vertical & 53 & 110 & $\mathrm{cs}$ & PPU-401 & \\
\hline
\end{tabular}


Table 11-16 Product Purification Section Vessels/Reactors, cont’d

\begin{tabular}{|c|c|c|c|c|c|c|c|c|c|}
\hline \multicolumn{10}{|c|}{ EQUIPMENT LIST - VESSELS / REACTORS } \\
\hline \multicolumn{5}{|c|}{ Client: Westinghouse Electric Company } & \multicolumn{5}{|c|}{ Signature: TGS } \\
\hline \multicolumn{5}{|c|}{ Unit: Hybrid Sulfur TCA } & \multicolumn{5}{|c|}{ Location: Pittsburgh, PA } \\
\hline \multirow[b]{2}{*}{ Item No. } & \multirow[b]{2}{*}{ Name } & \multirow{2}{*}{$\begin{array}{l}\text { Diameter } \\
(\mathrm{mm})\end{array}$} & \multirow{2}{*}{$\begin{array}{l}\text { Length } \\
(\mathrm{mm})\end{array}$} & \multirow{2}{*}{$\begin{array}{l}\text { Horizon/ } \\
\text { Vertical }\end{array}$} & \multicolumn{2}{|c|}{ Mechanical Design } & \multirow{2}{*}{$\begin{array}{l}\text { Material } \\
\text { C.A. }(\mathrm{mm})\end{array}$} & \multirow[b]{2}{*}{ PFD } & \multirow[b]{2}{*}{ Remarks } \\
\hline & & & & & $\begin{array}{l}\text { Pressure } \\
\text { (barg) }\end{array}$ & Temp $\left({ }^{\circ} \mathrm{C}\right)$ & & & \\
\hline $\begin{array}{l}\text { HPS-PPU } \\
\text { KO-27 }\end{array}$ & $\begin{array}{l}\text { Regen Heater } \\
\text { Knockout Drum }\end{array}$ & 1000 & 2400 & Vertical & 53 & 110 & cs & PPU -402 & \\
\hline $\begin{array}{c}\text { HPS-PPU } \\
\text { KO-28 }\end{array}$ & $\begin{array}{c}\text { O2 Regen Gas } \\
\text { Blower Suction } \\
\text { Drum }\end{array}$ & 800 & 2900 & Vertical & 26 & 100 & cs & PPU-403 & \\
\hline
\end{tabular}

Table 11-17 Product Purification Section Pumps

\begin{tabular}{|c|c|c|c|c|c|c|c|c|c|}
\hline \multicolumn{10}{|c|}{ EQUIPMENT LIST - PUMPS } \\
\hline \multicolumn{5}{|c|}{ Client: Westinghouse Electric Company } & \multicolumn{5}{|c|}{ Signature: TGS } \\
\hline \multicolumn{5}{|c|}{ Unit: Hybrid Sulfur TCA } & \multicolumn{5}{|c|}{ Location: Pittsburgh, PA } \\
\hline \multirow{2}{*}{ Item No. } & \multirow{2}{*}{ Name } & \multirow{2}{*}{ Type } & \multirow{2}{*}{$\begin{array}{l}\text { Rated } \\
\text { Flow } \\
\left(\mathrm{m}^{3} / \mathrm{h}\right)\end{array}$} & \multirow{2}{*}{$\begin{array}{l}\text { Differential } \\
\text { Pressure } \\
\text { bar }\end{array}$} & \multirow{2}{*}{$\begin{array}{c}\text { Motor } \\
\mathrm{kW}\end{array}$} & \multicolumn{2}{|c|}{ Material } & \multirow{2}{*}{ PFD } & \multirow{2}{*}{ Remarks } \\
\hline & & & & & & Casing & Impeller & & \\
\hline $\begin{array}{l}\text { HPS-PPU } \\
\text { PP-20A/B }\end{array}$ & $\begin{array}{l}\mathrm{NaOH} \text { Purge } \\
\text { Pump }\end{array}$ & Centrif. & 200 & 1.3 & 11 & CS & CS & PPU -403 & 75\% Efficiency \\
\hline
\end{tabular}

Table 11-18 Product Purification Section Compressors/Blowers/Vacuum Pumps

\begin{tabular}{|c|c|c|c|c|c|c|c|c|c|c|}
\hline \multicolumn{11}{|c|}{ EQUIPMENT LIST - COMPRESSORS / BLOWERS / VACUUM PUMPS } \\
\hline \multicolumn{6}{|c|}{ Client: Westinghouse Electric Company } & \multicolumn{5}{|c|}{ Signature: TGS } \\
\hline \multicolumn{6}{|c|}{ Unit: Hybrid Sulfur TCA } & \multicolumn{5}{|c|}{ Location: Pittsburgh. PA } \\
\hline \multirow[b]{2}{*}{ Item No. } & \multirow[b]{2}{*}{ Name } & \multirow[b]{2}{*}{ Type } & \multirow{2}{*}{$\begin{array}{l}\text { Capacity } \\
\left(\mathrm{Am}^{3} / \mathrm{h}\right)\end{array}$} & \multirow{2}{*}{$\begin{array}{c}\text { Suction } \\
\text { Pressure } \\
\text { (bar a ) }\end{array}$} & \multirow{2}{*}{$\begin{array}{l}\text { Differential } \\
\text { Pressure } \\
\text { (bar ) }\end{array}$} & \multicolumn{2}{|c|}{ Driver } & \multirow{2}{*}{$\begin{array}{l}\text { Material } \\
\text { C.A.(mm) }\end{array}$} & \multirow[b]{2}{*}{ PFD } & \multirow[b]{2}{*}{ Remarks } \\
\hline & & & & & & Type & $\begin{array}{l}\text { Rated } \\
\text { Power } \\
\text { (kW) }\end{array}$ & & & \\
\hline $\begin{array}{l}\text { HPS-PPU } \\
\text { PB-01 }\end{array}$ & $\begin{array}{c}\text { Hydrogen } \\
\text { Recirculation Blower }\end{array}$ & $\begin{array}{l}\text { Rotary } \\
\text { Blower }\end{array}$ & 500 & 39.6 & 1 & Electric & 160 & CS & PPU-401 & \\
\hline $\begin{array}{l}\text { HPS-PPU } \\
\text { PB-02 }\end{array}$ & Hydrogen Compressor & $\begin{array}{l}2 \text { Stage } \\
\text { Centrif. }\end{array}$ & 5127 & 20 & 20 & $\begin{array}{l}\text { Steam } \\
\text { Turbine }\end{array}$ & 3500 & cs & PPU-401 & $\begin{array}{c}2 \text { Stage Compressor w/ intercooler } \\
\text { and after cooler supplied as } \\
\text { packaged unit. }\end{array}$ \\
\hline $\begin{array}{l}\text { HPS-PPU } \\
\text { PB-03 }\end{array}$ & $\begin{array}{c}\text { O2 Regen } \\
\text { Gas Recirc. Blower }\end{array}$ & $\begin{array}{l}\text { Rotary } \\
\text { Blower }\end{array}$ & 315 & 20 & 25 & Electric & 75 & CS & PPU-403 & \\
\hline $\begin{array}{l}\text { HPS-PPU } \\
\text { PB-04 }\end{array}$ & $\begin{array}{l}\text { Oxygen } \\
\text { Compressor }\end{array}$ & $\begin{array}{l}2 \text { Stage } \\
\text { Centrif. }\end{array}$ & 2126 & 39.5 & 5 & $\begin{array}{l}\text { Steam } \\
\text { Turbine }\end{array}$ & 1400 & CS & PPU-403 & $\begin{array}{l}2 \text { Stage Compressor w/ intercooler } \\
\text { and after cooler supplied as } \\
\text { packaged unit. }\end{array}$ \\
\hline
\end{tabular}


Table 11-19 Product Purification Section Heat Exchangers

\begin{tabular}{|c|c|c|c|c|c|c|c|}
\hline \multicolumn{8}{|c|}{ EQUIPMENT LIST - HEAT EXCHANGERS } \\
\hline \multicolumn{5}{|c|}{ Client: Westinghouse Electric Company } & \multicolumn{3}{|c|}{ Signature: TGS } \\
\hline \multicolumn{5}{|c|}{ Unit: Hybrid Sulfur TCA } & \multicolumn{3}{|c|}{ Location: Pittsburgh. PA } \\
\hline \multirow{3}{*}{ Item No. } & \multirow{3}{*}{ Name } & \multirow{3}{*}{$\left.\begin{array}{c}\text { Area } \\
\left(\mathrm{m}^{2}\right)\end{array}\right)$} & \multicolumn{2}{|c|}{ Mechanical Design } & \multirow{3}{*}{ Type } & \multirow{3}{*}{ PFD } & \multirow{3}{*}{ Remarks } \\
\hline & & & Shell & Tube & & & \\
\hline & & & $\begin{array}{c}\text { Material } \\
\text { Pressure (bar g) } \\
\text { Temperature } \\
\left({ }^{\circ} \mathrm{C}\right)\end{array}$ & $\begin{array}{c}\text { Material } \\
\text { Pressure (bar g) } \\
\text { Temperature } \\
\left({ }^{\circ} \mathrm{C}\right)\end{array}$ & & & \\
\hline $\begin{array}{l}\text { HPS-PPU } \\
\text { HX-20 }\end{array}$ & $\begin{array}{c}\text { Hydrogen Compressor } \\
\text { Aftercooler }\end{array}$ & 280 & $\begin{array}{c}C S \\
53 \\
110\end{array}$ & $\begin{array}{l}\text { CS } \\
41 \\
100\end{array}$ & BEU & PPU-401 & \\
\hline $\begin{array}{l}\text { HPS-PPU } \\
\text { HX-21 }\end{array}$ & $\begin{array}{c}\mathrm{H} 2 \mathrm{O} \text { Absorber } \\
\text { Regeneration cooler }\end{array}$ & 65 & $\begin{array}{c}\text { CS } \\
54 \\
110\end{array}$ & $\begin{array}{l}\text { CS } \\
41 \\
100\end{array}$ & BEU & PPU-401 & \\
\hline $\begin{array}{l}\text { HPS-PPU } \\
\text { HX-22 }\end{array}$ & $\begin{array}{l}\text { HDS System } \\
\text { Heat Economizer }\end{array}$ & 1350 & $\begin{array}{c}11 / 4 \mathrm{Cr}, 1 / 2 \mathrm{MO} \\
52 \\
405\end{array}$ & $\begin{array}{c}11 / 4 \mathrm{Cr}, 1 / 2 \mathrm{MO} . \\
52 \\
405\end{array}$ & BEU & PPU-402 & \\
\hline $\begin{array}{l}\text { HPS-PPU } \\
\text { HX-23 }\end{array}$ & $\begin{array}{c}\text { HDS } \\
\text { Feed Heater }\end{array}$ & & $\begin{array}{c}11 / 4 \mathrm{Cr}, 1 / 2 \mathrm{Mo} \\
52 \\
400\end{array}$ & & Electric Heater & PPU.402 & $60 \mathrm{~kW}$ \\
\hline $\begin{array}{l}\text { HPS-PPU } \\
\text { HX-24 }\end{array}$ & $\begin{array}{c}\text { HDS } \\
\text { Trim Cooler }\end{array}$ & 650 & $\begin{array}{c}\text { CS } \\
52 \\
110\end{array}$ & $\begin{array}{c}\text { CS } \\
40 \\
100 \\
\end{array}$ & BEU & PPU-402 & \\
\hline $\begin{array}{l}\text { HPS-PPU } \\
\text { HX-25 }\end{array}$ & $\begin{array}{c}\text { Trace } \mathrm{H} 2 \mathrm{O} \text { Absorber } \\
\text { Regen Heater }\end{array}$ & & $\begin{array}{c}C S \\
52 \\
200\end{array}$ & & Electric Heater & PPU -402 & $80 \mathrm{~kW}$ \\
\hline
\end{tabular}

Table 11-19 Product Purification Section Heat Exchangers, cont'd

\begin{tabular}{|c|c|c|c|c|c|c|c|}
\hline \multicolumn{8}{|c|}{ EQUIPMENT LIST - HEAT EXCHANGERS } \\
\hline \multicolumn{5}{|c|}{ Client: Westinghouse Electric Company } & \multicolumn{3}{|c|}{ Signature: TGS } \\
\hline \multicolumn{5}{|c|}{ Unit: Hybrid Sulfur TCA } & \multicolumn{3}{|c|}{ Location: Pittsburgh, PA } \\
\hline \multirow{3}{*}{ Item No. } & \multirow{3}{*}{ Name } & \multirow{3}{*}{$\begin{array}{l}\begin{array}{c}\text { Area } \\
\left(\mathrm{m}^{2}\right)\end{array} \\
\text { (Total) }\end{array}$} & \multicolumn{2}{|c|}{ Mechanical Design } & \multirow{3}{*}{ Type } & \multirow{3}{*}{ PFD } & \multirow{3}{*}{ Remarks } \\
\hline & & & Shell & Tube & & & \\
\hline & & & $\begin{array}{c}\text { Material } \\
\text { Pressure (bar g) } \\
\text { Temperature } \\
\left.\text { ( }{ }^{\circ} \mathrm{C}\right)\end{array}$ & $\begin{array}{c}\text { Material } \\
\text { Pressure (bar g) } \\
\text { Temperature } \\
\left({ }^{\circ} \mathrm{C}\right) \\
\end{array}$ & & & \\
\hline $\begin{array}{c}\text { HPS-PPU } \\
\text { HX-26 }\end{array}$ & $\begin{array}{c}\text { Trace } \mathrm{H} 2 \mathrm{O} \text { Adsorber } \\
\text { Regen Cooler }\end{array}$ & 5 & $\begin{array}{c}\text { CS } \\
52 \\
110\end{array}$ & $\begin{array}{c}\text { CS } \\
40 \\
100\end{array}$ & BEU & PPU-402 & \\
\hline $\begin{array}{l}\text { HPS-PPU } \\
\text { HX-27 }\end{array}$ & $\begin{array}{l}\text { Hydrogen } \mathrm{H} 2 O \\
\text { Adsorber } \\
\text { Regen Heater }\end{array}$ & 35 & $\begin{array}{c}\text { CS } \\
40 \\
200\end{array}$ & $\begin{array}{c}\mathrm{CS} \\
52 \\
110\end{array}$ & BEU & PPU-402 & \\
\hline $\begin{array}{c}\text { HPS-PPU } \\
\text { HX-28 }\end{array}$ & $\begin{array}{l}\mathrm{SO} 2 \text { Adsorber } \\
\text { Regen Heater }\end{array}$ & 5 & $\begin{array}{c}\text { CS } \\
19 \\
200\end{array}$ & $\begin{array}{c}\text { CS } \\
25 \\
100\end{array}$ & BEU & PPU-403 & \\
\hline $\begin{array}{l}\text { HPS-PPU } \\
\text { HX-29 }\end{array}$ & $\begin{array}{l}\mathrm{H} 2 \mathrm{O} \text { Adsorber } \\
\text { Regen Heater }\end{array}$ & 10 & $\begin{array}{c}\text { CS } \\
19 \\
200\end{array}$ & $\begin{array}{c}C S \\
25 \\
100\end{array}$ & BEU & PPU-403 & \\
\hline $\begin{array}{l}\text { HPS-PPU } \\
\text { HX-30 }\end{array}$ & $\begin{array}{l}\mathrm{SO} 2 \text { Adsorber } \\
\text { Regen Cooler }\end{array}$ & 5 & $\begin{array}{c}\text { CS } \\
25 \\
100\end{array}$ & $\begin{array}{c}\text { CS } \\
19 \\
100\end{array}$ & BEU & PPU -403 & \\
\hline $\begin{array}{l}\text { HPS-PPU } \\
\text { HX-31 }\end{array}$ & $\begin{array}{l}\text { H2O Adsorber } \\
\text { Regen Cooler }\end{array}$ & 15 & $\begin{array}{c}\text { CS } \\
25 \\
100\end{array}$ & $\begin{array}{c}C S \\
19 \\
100\end{array}$ & BEU & PPU -403 & \\
\hline
\end{tabular}


Table 11-19 Product Purification Section Heat Exchangers, cont'd

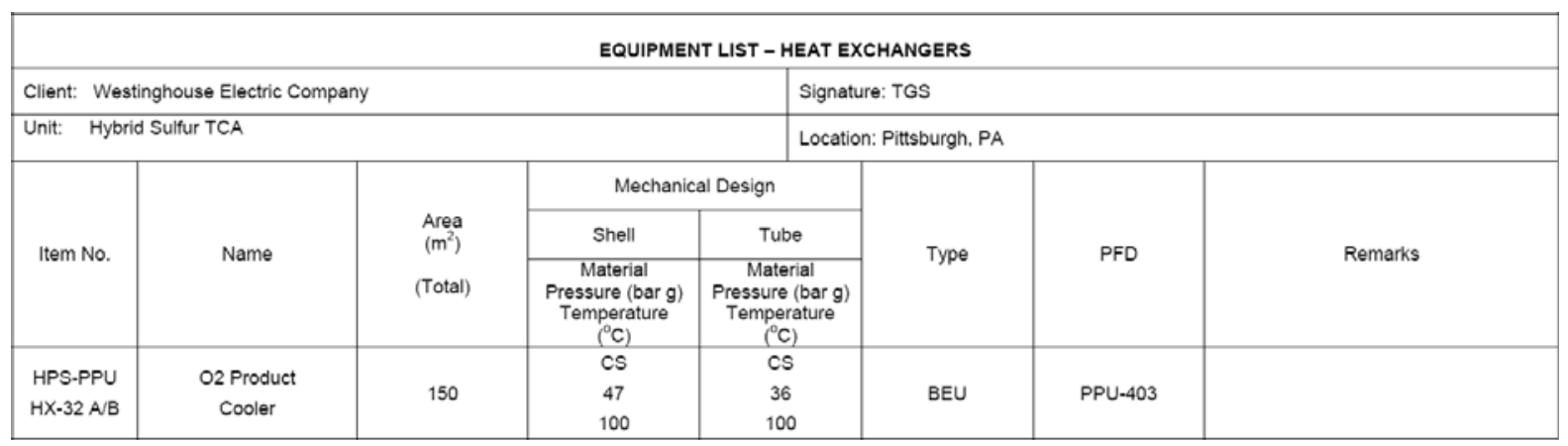




\subsection{APPENDIX - HYS PLANT MATERIALS SELECTION SUMMARY}

Appendix 12.0 contains the HyS plant materials selection summary mentioned in Section 6.2 .2

Table 12-1 Material Selection Table Based on Stream Analyses

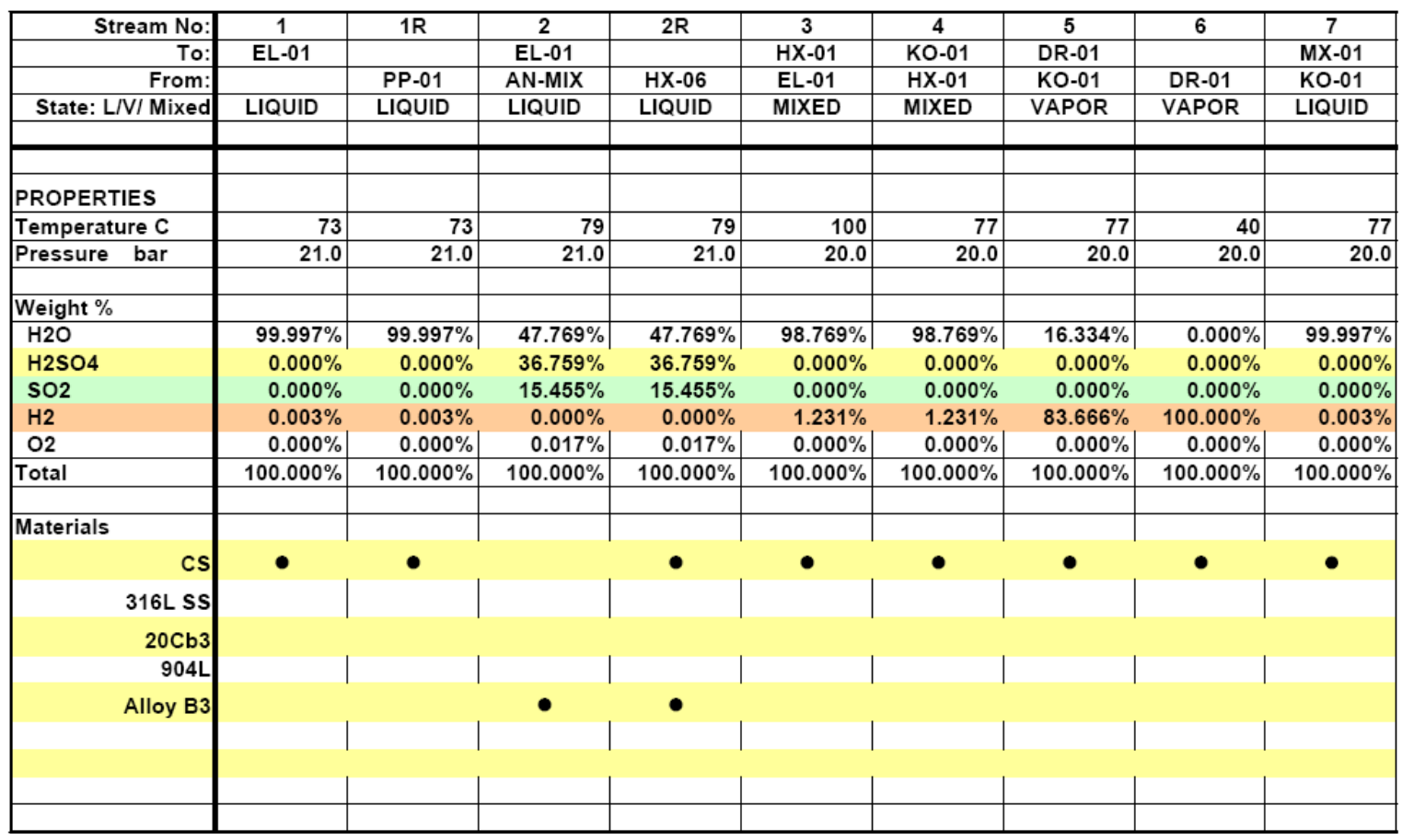

Notes:

1) Basis. Corrosion rates $<20$ mpy.

2) Where $\mathrm{H}_{2} \mathrm{SO}_{4}$ and $\mathrm{SO}_{2}$ are in combination, $\mathrm{H}_{2} \mathrm{SO}_{4}$ data is the basis for material selection.

3) * means no data are available. Material selection is based on the closest material properties available for the service conditions. Further study is required to determine the final material selection for the service.

4) For a number of the services required for this process there are alternative viable material selections. The material selected is believed to be the most economic of these options.

5) Materials such as brick-lined vessels and lined pipe should be evaluated as more economical alternatives in future work. 
Table 12-1 Material Selection Table Based on Stream Analyses, cont'd

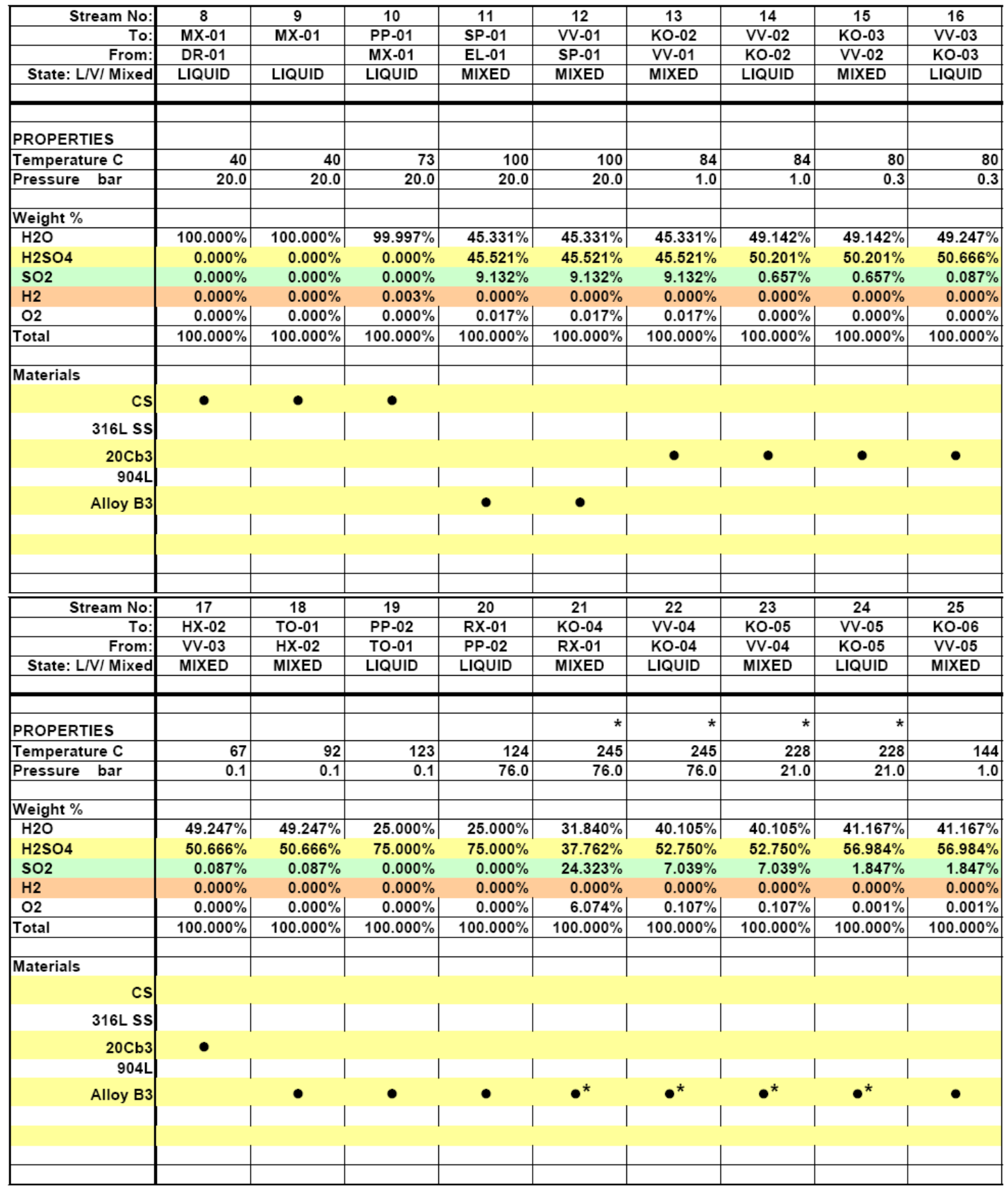


Table 12-1 Material Selection Table Based on Stream Analyses, cont'd

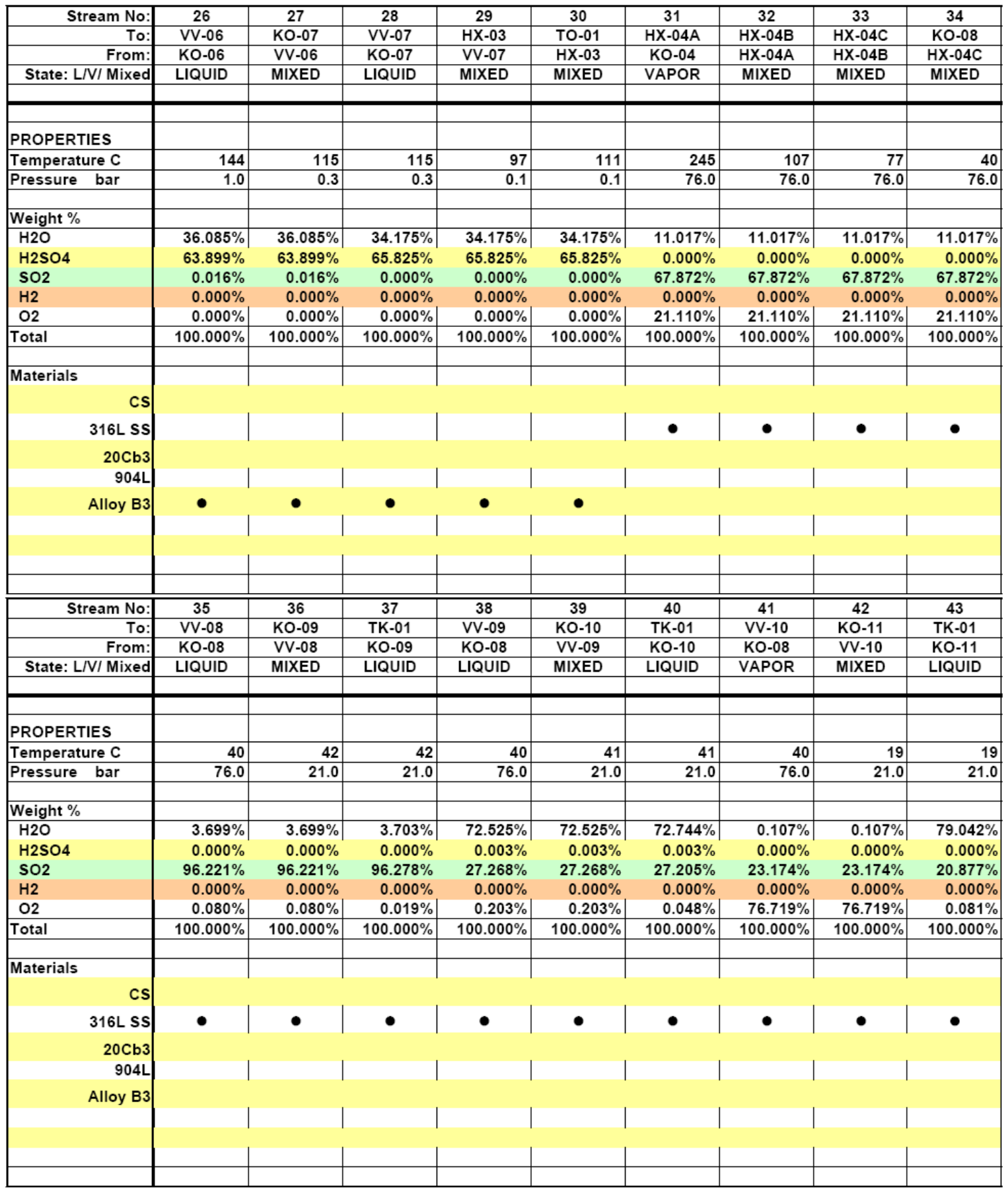


Table 12-1 Material Selection Table Based on Stream Analyses, cont'd

\begin{tabular}{|c|c|c|c|c|c|c|c|c|c|}
\hline Stream No: & 44 & 45 & 46 & 47 & 48 & 49 & 50 & 51 & 52 \\
\hline To: & TO-02 & TO-02 & TO-02 & TO-02 & HX-05 & PP-03 & TK-01 & HX-06 & HX-07 \\
\hline From: & KO-11 & KO-10 & KO-09 & KO-05 & SP-01 & HX-05 & PP-03 & TK-01 & KO-02 \\
\hline State: L/V/ Mixed & VAPOR & VAPOR & VAPOR & VAPOR & MIXED & LIQUID & LIQUID & LIQUID & VAPOR \\
\hline & & & & & & & & & \\
\hline \multicolumn{10}{|l|}{ PROPERTIES } \\
\hline Temperature $\mathrm{C}$ & 19 & 41 & 42 & 228 & 100 & 80 & 80 & 84 & 84 \\
\hline Pressure bar & 21.0 & 21.0 & 21.0 & 21.0 & 20.0 & 20.0 & 21.0 & 21.0 & 1.0 \\
\hline \multicolumn{10}{|l|}{ Weight $\%$} \\
\hline $\mathrm{H} 2 \mathrm{O}$ & $0.064 \%$ & $0.195 \%$ & $0.199 \%$ & $26.863 \%$ & $45.331 \%$ & $45.331 \%$ & $45.331 \%$ & $47.769 \%$ & $8.267 \%$ \\
\hline $\mathrm{H} 2 \mathrm{SO} 4$ & $0.000 \%$ & $0.000 \%$ & $0.000 \%$ & $0.000 \%$ & $45.521 \%$ & $45.521 \%$ & $45.521 \%$ & $36.759 \%$ & $0.000 \%$ \\
\hline $\mathrm{SO} 2$ & $23.175 \%$ & $48.169 \%$ & $48.857 \%$ & $71.718 \%$ & $9.132 \%$ & $9.132 \%$ & $9.132 \%$ & $15.455 \%$ & $91.554 \%$ \\
\hline $\mathrm{H} 2$ & $0.000 \%$ & $0.000 \%$ & $0.000 \%$ & $0.000 \%$ & $0.000 \%$ & $0.000 \%$ & $0.000 \%$ & $0.000 \%$ & $0.000 \%$ \\
\hline $\mathrm{O} 2$ & $76.762 \%$ & $51.636 \%$ & $50.944 \%$ & $1.418 \%$ & $0.017 \%$ & $0.017 \%$ & $0.017 \%$ & $0.017 \%$ & $0.179 \%$ \\
\hline Total & $100.000 \%$ & $100.000 \%$ & $100.000 \%$ & $100.000 \%$ & $100.000 \%$ & $100.000 \%$ & $100.000 \%$ & $100.000 \%$ & $100.000 \%$ \\
\hline \multicolumn{10}{|l|}{ Materials } \\
\hline \multicolumn{10}{|l|}{$\operatorname{cs}$} \\
\hline $316 \mathrm{~L} \mathrm{SS}$ & $\bullet$ & - & - & $\bullet$ & & & & & - \\
\hline $20 \mathrm{Cb} 3$ & \multicolumn{9}{|c|}{ - } \\
\hline \multicolumn{10}{|l|}{ 904L } \\
\hline \multirow[t]{4}{*}{ Alloy B3 } & \multicolumn{9}{|c|}{ - } \\
\hline & & & & & & & & & \\
\hline & & & & & & & & & \\
\hline & & & & & & & & & \\
\hline Stream No: & $\overline{53}$ & $\overline{54}$ & $\overline{55}$ & $\overline{56}$ & $\overline{57}$ & $\overline{58}$ & $\overline{59}$ & 260 & $\overline{61}$ \\
\hline \multirow{2}{*}{$\begin{array}{r}\text { To: } \\
\text { From: }\end{array}$} & KO-12 & HX-08A & HX-08B & HX-08C & KO-12 & CO-01 & KO-13 & MX-02 & TK-01 \\
\hline & HX-07 & KO-06 & HX-08A & HX-08B & HX-08C & $\mathrm{KO}-12$ & $\mathrm{CO}-01$ & $\mathrm{KO}-13$ & MX-02 \\
\hline \multirow[t]{2}{*}{ State: L/V/ Mixed } & MIXED & VAPOR & MIXED & MIXED & MIXED & VAPOR & MIXED & LIQUID & LIQUID \\
\hline & & & & & & & & & \\
\hline \multicolumn{10}{|l|}{ PROPERTIES } \\
\hline Temperature C & 40 & 144 & 107 & 77 & 40 & 40 & 40 & 40 & 41 \\
\hline \multirow[t]{2}{*}{ Pressure bar } & 1.0 & 1.0 & 1.0 & 1.0 & 1.0 & 1.0 & 21.0 & 21.0 & 21.0 \\
\hline \multirow{2}{*}{\multicolumn{10}{|c|}{ Weight \% }} \\
\hline & & & & & & & & & \\
\hline $\mathrm{H} 2 \mathrm{O}$ & $8.267 \%$ & $83.049 \%$ & $83.049 \%$ & $83.049 \%$ & $83.049 \%$ & $2.172 \%$ & $0.090 \%$ & $0.110 \%$ & $0.776 \%$ \\
\hline $\mathrm{H} 2 \mathrm{SO} 4$ & $0.000 \%$ & $0.000 \%$ & $0.000 \%$ & $0.000 \%$ & $0.000 \%$ & $0.000 \%$ & $0.000 \%$ & $0.000 \%$ & $0.000 \%$ \\
\hline SO2 & $91.554 \%$ & $16.938 \%$ & $16.938 \%$ & $16.938 \%$ & $16.938 \%$ & $97.652 \%$ & $90.255 \%$ & $99.878 \%$ & $99.222 \%$ \\
\hline $\mathrm{H} 2$ & $0.000 \%$ & $0.000 \%$ & $0.000 \%$ & $0.000 \%$ & $0.000 \%$ & $0.000 \%$ & $0.000 \%$ & $0.000 \%$ & $0.000 \%$ \\
\hline $\mathrm{O} 2$ & $0.179 \%$ & $0.013 \%$ & $0.013 \%$ & $0.013 \%$ & $0.013 \%$ & $0.176 \%$ & $9.655 \%$ & $0.013 \%$ & $0.002 \%$ \\
\hline Total & $100.000 \%$ & $100.000 \%$ & $100.000 \%$ & $100.000 \%$ & $100.000 \%$ & $100.000 \%$ & $100.000 \%$ & $100.000 \%$ & $100.000 \%$ \\
\hline \multicolumn{10}{|l|}{ Materials } \\
\hline \multicolumn{10}{|l|}{$\operatorname{cs}$} \\
\hline $316 \mathrm{~L} \mathrm{SS}$ & $\bullet$ & $\bullet$ & - & $\bullet$ & $\bullet$ & - & $\bullet$ & $\bullet$ & $\bullet$ \\
\hline \multicolumn{10}{|l|}{$20 \mathrm{Cb} 3$} \\
\hline \multicolumn{10}{|l|}{ 904L } \\
\hline \multicolumn{10}{|l|}{ Alloy B3 } \\
\hline & & & & & & & & & \\
\hline & & & & & & & & & \\
\hline & & & & & & & & & \\
\hline
\end{tabular}


Table 12-1 Material Selection Table Based on Stream Analyses, cont'd

\begin{tabular}{|c|c|c|c|c|c|c|c|c|c|}
\hline Stream No: & 62 & 63 & 64 & 65 & 66 & 67 & 68 & 69 & 70 \\
\hline To: & PP-04 & TK-01 & PP-05 & MX-02 & TO-02 & PP-06 & TO-02 & HX-09 & KO-14 \\
\hline From: & CO-01 & PP-04 & CO-01 & PP-05 & KO-13 & KO-12 & PP-06 & KO-03 & HX-09 \\
\hline State: L/V/ Mixed & LIQUID & LIQUID & LIQUID & LIQUID & VAPOR & LIQUID & LIQUID & VAPOR & MIXED \\
\hline & & & & & & & & & \\
\hline \multicolumn{10}{|l|}{ PROPERTIES } \\
\hline Temperature $\mathrm{C}$ & 40 & 41 & 40 & 41 & 40 & 40 & 40 & 80 & 40 \\
\hline Pressure bar & 2.8 & 21.0 & 7.6 & 21.0 & 21.0 & 1.0 & 21.0 & 0.3 & 0.3 \\
\hline \multicolumn{10}{|l|}{ Weight $\%$} \\
\hline $\mathrm{H} 2 \mathrm{O}$ & $87.068 \%$ & $87.068 \%$ & $0.786 \%$ & $0.786 \%$ & $0.008 \%$ & $95.215 \%$ & $95.215 \%$ & $37.841 \%$ & $37.841 \%$ \\
\hline $\mathrm{H} 2 \mathrm{SO} 4$ & $0.000 \%$ & $0.000 \%$ & $0.000 \%$ & $0.000 \%$ & $0.000 \%$ & $0.000 \%$ & $0.000 \%$ & $0.000 \%$ & $0.000 \%$ \\
\hline SO2 & $12.932 \%$ & $12.932 \%$ & $99.212 \%$ & $99.212 \%$ & $51.476 \%$ & $4.784 \%$ & $4.784 \%$ & $62.159 \%$ & $62.159 \%$ \\
\hline $\mathrm{H} 2$ & $0.000 \%$ & $0.000 \%$ & $0.000 \%$ & $0.000 \%$ & $0.000 \%$ & $0.000 \%$ & $0.000 \%$ & $0.000 \%$ & $0.000 \%$ \\
\hline $\mathrm{O} 2$ & $0.000 \%$ & $0.000 \%$ & $0.001 \%$ & $0.001 \%$ & $48.516 \%$ & $0.000 \%$ & $0.000 \%$ & $0.001 \%$ & $0.001 \%$ \\
\hline Total & $100.000 \%$ & $100.000 \%$ & $100.000 \%$ & $100.000 \%$ & $100.000 \%$ & $100.000 \%$ & $100.000 \%$ & $100.000 \%$ & $100.000 \%$ \\
\hline \multicolumn{10}{|l|}{ Materials } \\
\hline \multicolumn{10}{|l|}{$\operatorname{cs}$} \\
\hline $316 \mathrm{~L} \mathrm{SS}$ & $\bullet$ & $\bullet$ & - & $\bullet$ & $\bullet$ & - & $\bullet$ & $\bullet$ & - \\
\hline \multicolumn{10}{|l|}{$20 \mathrm{Cb} 3$} \\
\hline \multicolumn{10}{|l|}{ 904L } \\
\hline \multicolumn{10}{|l|}{ Alloy B3 } \\
\hline & & & & & & & & & \\
\hline & & & & & & & & & \\
\hline & & & & & & & & & \\
\hline Stream No: & $\overline{71}$ & 72 & 73 & $\overline{74}$ & $\overline{75}$ & $\overline{76}$ & 77 & 78 & 79 \\
\hline \multirow{2}{*}{$\begin{array}{r}\text { To: } \\
\text { From: }\end{array}$} & $\mathrm{HX}-10 \mathrm{~A}$ & $\mathrm{HX}-10 \mathrm{~B}$ & KO-14 & PP-07 & TO-02 & EJ-01 & EJ-01 & $\mathrm{HX}-11$ & MX-03 \\
\hline & KO-07 & $\mathrm{HX}-10 \mathrm{~A}$ & $\mathrm{HX}-10 \mathrm{~B}$ & KO-14 & PP-07 & KO-14 & & EJ-01 & $\mathrm{HX}-11$ \\
\hline \multirow[t]{2}{*}{ State: L/V/ Mixed } & VAPOR & MIXED & LIQUID & LIQUID & LIQUID & VAPOR & MIXED & VAPOR & LIQUID \\
\hline & & & & & & & & & \\
\hline \multicolumn{10}{|l|}{ PROPERTIES } \\
\hline Temperature C & 115 & 77 & 40 & 41 & 41 & 41 & 170 & 94 & 40 \\
\hline \multirow[t]{2}{*}{ Pressure bar } & 0.3 & 0.3 & 0.3 & 0.3 & 21.0 & 0.3 & 7.9 & 1.0 & 1.0 \\
\hline & & & & & & & & & \\
\hline \multicolumn{10}{|l|}{ Weight \% } \\
\hline $\mathrm{H} 2 \mathrm{O}$ & $99.455 \%$ & $99.455 \%$ & $99.455 \%$ & $98.706 \%$ & $98.706 \%$ & $8.648 \%$ & $100.000 \%$ & $31.997 \%$ & $54.177 \%$ \\
\hline $\mathrm{H} 2 \mathrm{SO} 4$ & $0.000 \%$ & $0.000 \%$ & $0.000 \%$ & $0.000 \%$ & $0.000 \%$ & $0.000 \%$ & $0.000 \%$ & $0.000 \%$ & $0.000 \%$ \\
\hline SO2 & $0.545 \%$ & $0.545 \%$ & $0.545 \%$ & $1.294 \%$ & $1.294 \%$ & $91.351 \%$ & $0.000 \%$ & $68.002 \%$ & $45.821 \%$ \\
\hline $\mathrm{H} 2$ & $0.000 \%$ & $0.000 \%$ & $0.000 \%$ & $0.000 \%$ & $0.000 \%$ & $0.000 \%$ & $0.000 \%$ & $0.000 \%$ & $0.000 \%$ \\
\hline $\mathrm{O} 2$ & $0.000 \%$ & $0.000 \%$ & $0.000 \%$ & $0.000 \%$ & $0.000 \%$ & $0.001 \%$ & $0.000 \%$ & $0.001 \%$ & $0.001 \%$ \\
\hline Total & $100.000 \%$ & $100.000 \%$ & $100.000 \%$ & $100.000 \%$ & $100.000 \%$ & $100.000 \%$ & $100.000 \%$ & $100.000 \%$ & $100.000 \%$ \\
\hline \multicolumn{10}{|l|}{ Materials } \\
\hline $\operatorname{cs}$ & $\bullet$ & • & - & - & $\bullet$ & & $\bullet$ & & \\
\hline 316L ss & & & & & & - & & $\bullet$ & $\bullet$ \\
\hline \multicolumn{10}{|l|}{$20 \mathrm{Cb} 3$} \\
\hline \multicolumn{10}{|l|}{ 904L } \\
\hline \multicolumn{10}{|l|}{ Alloy B3 } \\
\hline & & & & & & & & & \\
\hline & & & & & & & & & \\
\hline & & & & & & & & & \\
\hline
\end{tabular}


Table 12-1 Material Selection Table Based on Stream Analyses, cont'd

\begin{tabular}{|c|c|c|c|c|c|c|c|c|c|}
\hline Stream No: & 80 & 81 & 82 & 83 & 84 & 85 & 86 & 87 & 88 \\
\hline To: & KO-12 & PP-08 & TO-02 & EJ-02 & EJ-02 & $\mathrm{HX}-12$ & PP-09 & MX-03 & \\
\hline From: & $\mathrm{HX}-11$ & TO-01 & PP-08 & TO-01 & & EJ-02 & $\mathrm{HX}-12$ & PP-09 & MX-03 \\
\hline State: L/V/ Mixed & VAPOR & LIQUID & LIQUID & VAPOR & MIXED & VAPOR & LIQUID & LIQUID & LIQUID \\
\hline & & & & & & & & & \\
\hline \multicolumn{10}{|l|}{ PROPERTIES } \\
\hline Temperature $\mathrm{C}$ & 40 & 40 & 40 & 40 & 170 & 95 & 40 & 40 & 40 \\
\hline Pressure bar & 1.0 & 0.1 & 21.0 & 0.1 & 7.9 & 0.3 & 0.3 & 1.0 & 1.0 \\
\hline \multicolumn{10}{|l|}{ Weight $\%$} \\
\hline $\mathrm{H} 2 \mathrm{O}$ & $1.821 \%$ & $99.854 \%$ & $99.854 \%$ & $57.177 \%$ & $100.000 \%$ & $74.694 \%$ & $84.718 \%$ & $84.718 \%$ & $58.959 \%$ \\
\hline $\mathrm{H} 2 \mathrm{SO} 4$ & $0.000 \%$ & $0.000 \%$ & $0.000 \%$ & $0.000 \%$ & $0.000 \%$ & $0.000 \%$ & $0.000 \%$ & $0.000 \%$ & $0.000 \%$ \\
\hline SO2 & $98.179 \%$ & $0.146 \%$ & $0.146 \%$ & $42.823 \%$ & $0.000 \%$ & $25.306 \%$ & $15.282 \%$ & $15.282 \%$ & $41.040 \%$ \\
\hline $\mathrm{H} 2$ & $0.000 \%$ & $0.000 \%$ & $0.000 \%$ & $0.000 \%$ & $0.000 \%$ & $0.000 \%$ & $0.000 \%$ & $0.000 \%$ & $0.000 \%$ \\
\hline $\mathrm{O} 2$ & $0.000 \%$ & $0.000 \%$ & $0.000 \%$ & $0.000 \%$ & $0.000 \%$ & $0.000 \%$ & $0.000 \%$ & $0.000 \%$ & $0.001 \%$ \\
\hline Total & $100.000 \%$ & $100.000 \%$ & $100.000 \%$ & $100.000 \%$ & $100.000 \%$ & $100.000 \%$ & $100.000 \%$ & $100.000 \%$ & $100.000 \%$ \\
\hline \multicolumn{10}{|l|}{ Materials } \\
\hline $\operatorname{cs}$ & & - & - & & $\bullet$ & & & & \\
\hline 316L SS & $\bullet$ & & & $\bullet$ & & $\bullet$ & $\bullet$ & $\bullet$ & $\bullet$ \\
\hline \multicolumn{10}{|l|}{$20 \mathrm{Cb} 3$} \\
\hline \multicolumn{10}{|l|}{ 904L } \\
\hline \multicolumn{10}{|l|}{ Alloy B3 } \\
\hline & & & & & & & & & \\
\hline & & & & & & & & & \\
\hline & & & & & & & & & \\
\hline Stream No: & 89 & 90 & 91 & 92 & 93 & $\overline{94}$ & ACID & BFW & FEED \\
\hline \multirow{2}{*}{$\begin{array}{r}\text { To: } \\
\text { From: }\end{array}$} & KO-14 & DR-02 & & TK-01 & TK-01 & TO-02 & MX-00 & SG-01 & AN-MIX \\
\hline & $\mathrm{HX}-12$ & TO-02 & DR-02 & TO-02 & DR-02 & TK-01 & & & MX-00 \\
\hline \multirow[t]{2}{*}{ State: L/V/ Mixed } & VAPOR & VAPOR & VAPOR & LIQUID & LIQUID & VAPOR & LIQUID & LIQUID & LIQUID \\
\hline & & & & & & & & & \\
\hline & & & & & & & & & \\
\hline \multicolumn{10}{|l|}{ PROPERTIES } \\
\hline Temperature C & 40 & 41 & 40 & 74 & 40 & 84 & 80 & 40 & 80 \\
\hline Pressure bar & 0.3 & 21.0 & 21.0 & 21.0 & 21.0 & 21.0 & 21.0 & 1.0 & 21.0 \\
\hline \multirow{2}{*}{\multicolumn{10}{|c|}{ Weight \% }} \\
\hline & & & & & & & & & \\
\hline $\mathrm{H} 2 \mathrm{O}$ & $7.999 \%$ & $0.246 \%$ & $0.000 \%$ & $86.997 \%$ & $35.927 \%$ & $0.637 \%$ & $56.512 \%$ & $100.000 \%$ & $47.769 \%$ \\
\hline $\mathrm{H} 2 \mathrm{SO} 4$ & $0.000 \%$ & $0.000 \%$ & $0.000 \%$ & $0.000 \%$ & $0.000 \%$ & $0.000 \%$ & $43.488 \%$ & $0.000 \%$ & $36.759 \%$ \\
\hline $\mathrm{SO} 2$ & $92.001 \%$ & $0.439 \%$ & $0.000 \%$ & $12.967 \%$ & $64.073 \%$ & $77.726 \%$ & $0.000 \%$ & $0.000 \%$ & $15.455 \%$ \\
\hline $\mathrm{H} 2$ & $0.000 \%$ & $0.000 \%$ & $0.000 \%$ & $0.000 \%$ & $0.000 \%$ & $0.000 \%$ & $0.000 \%$ & $0.000 \%$ & $0.000 \%$ \\
\hline $\mathrm{O} 2$ & $0.000 \%$ & $99.315 \%$ & $100.000 \%$ & $0.035 \%$ & $0.000 \%$ & $21.636 \%$ & $0.000 \%$ & $0.000 \%$ & $0.017 \%$ \\
\hline Total & $100.000 \%$ & $100.000 \%$ & $100.000 \%$ & $100.000 \%$ & $100.000 \%$ & $100.000 \%$ & $100.000 \%$ & $100.000 \%$ & $100.000 \%$ \\
\hline \multirow{2}{*}{\multicolumn{10}{|c|}{ Materials }} \\
\hline & & & & & & & & & \\
\hline cs & & $\bullet$ & $\bullet$ & & & & & $\bullet$ & • \\
\hline $316 \mathrm{~L} \mathrm{SS}$ & $\bullet$ & & & $\bullet$ & $\bullet$ & $\bullet$ & & & \\
\hline \multicolumn{10}{|l|}{$20 \mathrm{Cb} 3$} \\
\hline \multicolumn{10}{|l|}{ 904L } \\
\hline \multicolumn{10}{|l|}{ Alloy B3 } \\
\hline & & & & & & & & & \\
\hline & & & & & & & & & \\
\hline & & & & & & & & & \\
\hline
\end{tabular}


Table 12-1 Material Selection Table Based on Stream Analyses, cont'd

\begin{tabular}{|c|c|c|c|}
\hline Stream No: & MAKEUP & $\mathrm{SO} 2$ & STEAM \\
\hline To: & TK-01 & MX-00 & \\
\hline From: & & & SG-01 \\
\hline State: L/V/ Mixed & LIQUID & MIXED & MIXED \\
\hline & & & \\
\hline \multicolumn{4}{|l|}{ PROPERTIES } \\
\hline Temperature C & 40 & 80 & 170 \\
\hline Pressure bar & 21.0 & 21.0 & 7.9 \\
\hline \multicolumn{4}{|l|}{ Weight \% } \\
\hline $\mathrm{H} 2 \mathrm{O}$ & $4.044 \%$ & $0.000 \%$ & $100.000 \%$ \\
\hline $\mathrm{H} 2 \mathrm{SO}_{4}$ & $95.956 \%$ & $0.000 \%$ & $0.000 \%$ \\
\hline $\mathrm{SO} 2$ & $0.000 \%$ & $99.890 \%$ & $0.000 \%$ \\
\hline H2 & $0.000 \%$ & $0.000 \%$ & $0.000 \%$ \\
\hline $\mathrm{O} 2$ & $0.000 \%$ & $0.110 \%$ & $0.000 \%$ \\
\hline Total & $100.000 \%$ & $100.000 \%$ & $100.000 \%$ \\
\hline \multicolumn{4}{|l|}{ Materials } \\
\hline cs & $\bullet$ & • & • \\
\hline \multicolumn{4}{|l|}{$316 \mathrm{~L} \mathrm{SS}$} \\
\hline \multicolumn{4}{|l|}{$20 \mathrm{Cb} 3$} \\
\hline 904L & & & \\
\hline \multicolumn{4}{|l|}{ Alloy B3 } \\
\hline & & & \\
\hline & & & \\
\hline & & & \\
\hline
\end{tabular}




\subsection{APPENDIX - ECONOMIC GROUNDRULES}

Financial parameters are drawn from the past H2A effort as applicable for this current effort, with the following modifications:

- Reference year dollars are 2nd Quarter 2008, versus 2005 in H2A.

- Hydrogen production capacity factor is $94 \%$ for the HyS case, as it was for the WEC NGNP PCDR analyses. A 90\% capacity factor was applied in the past H2A production options as a common reference, and this is retained for the comparative baseline calculations.

- Economies that stem from facility sharing, for example the economy of scale for a single large steam turbine generator, assume the installation is a four-reactor modular plant. However, all cost data in the report apply to a single reactor module coupled to a HyS water splitting plant of the size matched to a single reactor module.

- The Fixed O\&M Costs planned payments to a Decommissioning Fund. An allowance of $\$ 50 \mathrm{M}$ is included for the cost of decommissioning a PBMR modular reactor unit. Payments into a decommissioning fund are assumed to grow over a 40 -yr fund life at 5.5\%.

- Cost escalation has been added to the H2A model for some costs, in particular for the HyS calculation the costs of nuclear fuel and imported electricity are escalated.

The following remaining financial parameters are directly assumed from the past $\mathrm{H} 2 \mathrm{~A}$ effort:

- An after income tax internal rate of return (IRR) of $10 \%$ has been applied as a reference value. The sensitivity of the levelized hydrogen price to the IRR is determined over the range of interest.

- An effective income tax rate of $38.9 \%$ is applied based on a federal tax rate of $35 \%$ and a state tax rate of $6 \%$.

- Facility lives of 40 years of operation are applied as the analyses period. Any shorter life limiting components are replaced at designated intervals.

- Accelerated depreciation facility lives of 20 years and the MACRS schedule per the IRS code are applied for the energy source plants, as well as the hydrogen production plants.

- In the analyses one can apply a general inflation rate, but in the model the results are deflated back to reference year dollars so inflation is nominally irrelevant, but it refines the depreciation costs and the related after income tax cash flows. A rate of $1.9 \%$ was taken as the $\mathrm{H} 2 \mathrm{~A}$ reference rate. 
- $100 \%$ equity financing is selected for the reference cases, with sensitivities for various debt financing considerations.

- All nuclear production concepts are assumed to be commercially mature and have been evaluated for a consistent 2030 to 2070 service timeframe.

- Capital cost contingency adjustment is made to the total initial capital cost such that the resulting cost represents a mean or expected value. This cost is the baseline value from which hydrogen price sensitivity can be calculated. Periodic replacement capital includes the same contingency.

- A nominal three-year construction period is applied with $25 \%, 40 \%$ and $35 \%$ of the costs incurred respectively

- Periodic capital replacements, e.g. the intermediate heat exchangers, are added to the capital cash flow and depreciated over the useful lives. In addition, an allowance for an annual capital replacement of $0.5 \% / \mathrm{yr}$ is included. The H2A DCF analyses apply both periodic and annual capital replacements rigorously with their respective depreciation schedules.

- Working capital is included in the H2A calculations. The H2A reference rate is used, which is $15 \%$ of the annual change in total operating costs.

- A constant site size of 400 acres has been applied for all options at an assumed unit cost of 5,000 \$/acre.

- An average burdened labor rate of $50 \$ / \mathrm{hr}$, plus a $20 \%$ G\&A adder, have been applied consistently for the plant staffs, which are estimated separately for the different options along with the respective maintenance cost estimates.

- Property taxes and business insurance are consistently estimated based on $2 \% / \mathrm{yr}$ of the total initial capital costs.

- Sales taxes are not included on basis that facilities and related purchases are wholesale and through a general contractor entity.

- Plant startup is considered to occur over one year. In that period, revenues are assumed to be $50 \%$ of subsequent full-year revenues and variable costs are assumed to be $50 \%$ likewise. Fixed annual costs are taken at $100 \%$ in the startup year.

- Reference fuel and feedstock values are automatically incorporated into the analysis tool with the exception of the values for nuclear fuel are developed externally.

- The delivery pressure at all production plant gates is consistently 21 bar (300 psig). If a significantly higher pressure is inherent to the process, a pumping power credit is applied for pressure greater than 300 psig.

- No central storage is included at the production plants other than buffer storage, as required for efficient operations.

- $\mathrm{CO}_{2}$ capture and sequestration is properly applied as a cost to emitting technologies, but it can also enter in to the evaluation of the nuclear hydrogen 
cases as a credit. In accordance with the $\mathrm{H} 2 \mathrm{~A}$ modeling groundrules sensitivity included at 27 \$/MT CO 2 (100 \$/MT C).

- Oxygen byproduct credit is included in the reference case, and oxygen credit is included in the sensitivity analysis. The reference credit is to be applied at 40 \$/MT, which is about today's industrial oxygen price. 